UNIVERSIDADE DE SÃO PAULO

FACULDADE DE FILOSOFIA, LETRAS E CIÊNCIAS HUMANAS

DEPARTAMENTO DE LETRAS CLÁSSICAS E VERNÁCULAS

PROGRAMA DE PÓS-GRADUAÇÃO EM FILOLOGIA E LÍNGUA PORTUGUESA

SOLANGE UGO LUQUES

\title{
Produção de texto acadêmico em Língua Portuguesa: ensino que combina ambientes presenciais e virtuais de aprendizagem
}

Versão corrigida

São Paulo

2016 


\section{SOLANGE UGO LUQUES}

\section{Produção de texto acadêmico em Língua Portuguesa: ensino que combina ambientes presenciais e virtuais de aprendizagem}

Tese apresentada ao Programa de PósGraduação em Filologia e Língua Portuguesa do Departamento de Letras Clássicas e Vernáculas da Faculdade de Filosofia, Letras e Ciências Humanas da Universidade de São Paulo, para a obtenção do título de Doutor.

Orientadora: Profa. Dra. Zilda Gaspar Oliveira de Aquino

Versão corrigida

São Paulo

2016 
Nome: LUQUES, Solange Ugo

Título: Produção de texto acadêmico em Língua Portuguesa: ensino que combina ambientes presenciais e virtuais de aprendizagem

Tese apresentada ao Programa de Pós-Graduação em Filologia e Língua Portuguesa do Departamento de Letras Clássicas e Vernáculas da Faculdade de Filosofia, Letras e Ciências Humanas da Universidade de São Paulo, para a obtenção do título de Doutor.

Aprovada em:

Banca Examinadora

Prof. Dr. Instituição:

Julgamento:

Assinatura:

Prof. Dr. Instituição:

Julgamento:

Assinatura:

Prof. Dr. Instituição:

Julgamento:

Assinatura:

Prof. Dr. Instituição:

Julgamento:

Assinatura:

Prof. Dr. Instituição:

Julgamento:

Assinatura: 
Aos meus amores,

Luiz Carlos,

Isabela,

Mariana,

Enrico

e os que virão,

Que me inspiraram, incentivaram e colaboraram de várias formas, com carinho. 


\section{AGRADECIMENTOS}

A Deus, pela vida.

À Professora Dra. Zilda Gaspar Oliveira de Aquino, que me aceitou novamente nos estudos do doutorado e continuou a me orientar com firmeza e carinho, nos meios acadêmicos e na vida. Guardo para sempre suas palavras sábias, animadoras e amorosas, em todos os momentos. Não poderia ter escolhido orientadora melhor.

Às Professoras Doutoras Maria das Graças Soares Rodrigues e Sueli Cristina Marquesi, pelo respeito que demonstraram em relação a mim e a meu trabalho e propriedade com que me aconselharam durante o processo de Qualificação. Reafirmo minha admiração pela excelência do conhecimento que possuem e pela generosidade com que o partilharam comigo.

À Universidade de São Paulo, USP, por ter me concedido a oportunidade e o espaço para desenvolver este trabalho, principalmente aos professores de cujas aulas participei.

A meu neto Enrico e aos que ainda virão, sementes de amor que me inspiram ao contínuo aperfeiçoamento.

A meu marido, Luiz Carlos, por seu amor, sua paciência, seu bom humor e seu incentivo.

Às minhas meninas Isabela e Mariana, pelas mulheres fortes que se tornaram, sem esquecer a doçura; pelo companheirismo e pela ajuda nas horas de dificuldades e desânimo; pelo carinho que têm por mim. A Fernando e Leandro por amá-las.

À minha mãe, Nélia, minha eterna defensora, conselheira, colaboradora, companheira de todas as horas. A saudade se mistura à certeza de que ainda me acompanha e protege.

À minha avó, Lina Cândida, meu avô Sylvio e meu pai, Giuseppe, meu sogro José. Sinto que, onde quer que estejam, ainda me acompanham e vibram com minhas realizações.

A meu irmão Antônio, minha sogra Pedra e todos os parentes e amigos que me apoiaram e incentivaram, mesmo sem compreender muito bem o que eu fazia.

A todos os colegas de estudos e pesquisas com quem convivi neste período.

Aos professores e alunos que aceitaram responder às pesquisas que lhes propus e me autorizaram a reproduzir suas respostas.

Aos alunos que autorizaram a reprodução de suas atividades.

A todos os meus alunos, pelo que me ensinaram. 
A linguagem é vista como um modo de interação que ao mesmo tempo modela, expande e muda o contexto numa complexa articulação colaborativa na qual os participantes estão envolvidos. 


\section{RESUMO}

LUQUES, S. U. Produção de texto acadêmico em Língua Portuguesa: ensino que combina ambientes presenciais e virtuais de aprendizagem. 2016. $244 \mathrm{f}$. Tese (Doutorado) - Faculdade de Filosofia, Letras e Ciências Humanas da Universidade de São Paulo, São Paulo, 2016.

O crescimento do acesso à tecnologia, seja ela representada pela internet, pelas redes sociais ou pelas plataformas virtuais de educação, amplia consideravelmente a participação dos indivíduos na circulação de conteúdos e na construção do conhecimento. Em decorrência dessa universalização das novas tecnologias e da expansão das possibilidades de conexão e colaboração virtual, autores como Swales e Feak (2012) indicam que as atividades acadêmicas em geral e, em particular, a leitura e escrita acadêmicas, por meio das quais divulga-se e consolida-se o conhecimento científico, estão cada vez mais colaborativas e incorporadas em contextos sociais e profissionais. Como consequência, é possível observar a crescente valorização do ensino de escrita acadêmica, seja no Brasil, pelo aumento na oferta de cursos livres ou de extensão sobre o assunto, embora em número insuficiente para atender à demanda por parte de alunos; seja nas universidades europeias e americanas, onde estudiosos de novas tendências nas práticas de escrita no ensino superior, como Castelló e Donahue (2012), afirmam que a produção escrita de universitários é forma de promover uma aprendizagem mais ativa, construtiva e reflexiva. No Brasil, se por um lado a cena universitária sofre alterações como consequência da criação de políticas públicas de inclusão social para promover a democratização do acesso ao ensino superior, por outro, tomamos conhecimento de dados oficiais sobre o Exame Nacional do Ensino Médio (ENEM) de 2014, que revelam uma queda de 9,7\% na performance dos alunos brasileiros em redação, estatística que tomamos como alerta de que o desempenho linguístico dos ingressantes na universidade brasileira precisa ser observado com mais atenção, em vista de que haverá novas demandas em termos de leitura e escrita que deverão ser supridas para que sua atuação no ensino superior seja satisfatória. Em vista disso, propomos promover o ensino de produção de gêneros acadêmicos como o artigo científico em Língua Portuguesa no ensino superior, mediante a combinação de atividades interativas realizadas em ambientes presenciais e virtuais, como modo de assegurar o desenvolvimento, por parte dos alunos, de competências complexas em termos de prática escrita, além de auxiliá-los a participarem de forma mais integrada e reflexiva do processo de construção do conhecimento acadêmico. Para tanto, propomos, metodologicamente, as seguintes ações: uma investigação teórica com base na literatura de referência sobre interação, cognição, ensino de produção de texto acadêmico e ambientes de aprendizagem; uma investigação de caráter etnográfico com observação participante por meio da aplicação de uma proposta de ensino que envolve uma concepção particular do gênero artigo científico e a combinação de atividades em ambientes presenciais e virtuais; um questionamento a professores da área de ensino de produção textual; e um questionamento a alunos que participaram das aplicações dessa proposta. Consideramos que uma experiência bem ajustada de aprendizagem da produção do artigo científico, em que a Língua Portuguesa é instrumento de construção de conhecimento, pode propiciar melhor inserção social do estudante, por levá-lo a dominar um gênero que vai contribuir para legitimar seu discurso na área da ciência em geral, seja dentro da universidade, seja no âmbito profissional.

Palavras-chave: Ensino em Língua Portuguesa. Artigo científico. Interação. Cognição. Aprendizagem combinada. 


\begin{abstract}
LUQUES, S. U. Academic writing in Portuguese: teaching that blends classroom and virtual learning environments. 2016. 244 f. Tese (Doutorado) - Faculdade de Filosofia, Letras e Ciências Humanas da Universidade de São Paulo, São Paulo, 2016.
\end{abstract}

The increase of technology access, whether represented by the internet, social networks or virtual learning platforms, considerably extends the participation of individuals in content circulation and knowledge building. As a result of this standardization of new technologies and expansion of connection possibilities and virtual collaboration, authors such as Swales and Feak (2012) suggest that academic activities in general and, in particular, reading and academic writing, through which scientific knowledge is disclosed and consolidated, are becoming increasingly collaborative and incorporated into social and professional contexts. As a result, we can observe growing valorization of teaching academic writing, both in Brazil, by rising the offer of open or extension courses on the subject, although insufficient in number to meet the demand from students; and in european and american universities, where scholars of new trends in academic writing in higher education, as Castelló and Donahue (2012), argue that enhancing students' writing is a way to promote a more active, constructive and reflective learning. In Brazil, if on one hand university scenario is altered as a result of social inclusion public policies to promote democratization of access to higher education, on the other, we become aware of official data on Secondary Education National Examination (ENEM) 2014, showing a decrease of 9.7\% in Brazilian students writing achievement, statistics that we take as a warning that Brazilian freshmen's linguistic performance needs to be observed more closely, having in mind that there will be new demands in terms of reading and writing that should be met so that their activities in higher education will be satisfactory. In view of this, we propose to promote the teaching in Portuguese of genres as academic papers in higher education through a combination of interactive activities in face-to-face and virtual environments, as a means of ensure the development, by the students, of complex skills in writing practice, and help them to participate in a more integrated and reflective way of academic knowledge building process. Therefore, we propose, methodologically, the following actions: a theoretical investigation based on the reference literature on interaction, cognition, teaching of academic writing and learning environments; an ethnographic research with participant observation by applying a teaching proposal that involves a particular conception of scientific paper gender and the combination of activities in face to face and virtual environments; an inquiry to teachers of the writing area of education; and an inquiry to students who participated in the application of this proposal. We believe that a well-adjusted learning experience of scientific paper writing, in which the Portuguese language is an instrument of knowledge building, can provide better social integration of the student, causing him to dominate a genre that will help to legitimize his speech in science in general, both in the university and professional fields.

Keywords: Teaching in Portuguese. Scientific paper. Interaction. Cognition. Blended learning. 
Figura 1- Diagrama básico do processo de mesclagem (FAUCONNIER e TURNER, 2002, p. 45)

Figura 2 - Considerações sobre escrita acadêmica (SWALES e FEAK, 2012, p. 3)

Figura 3 - Formato geral de um artigo científico (SWALES e FEAK, 2004, p. 222) 115 e 138

Figura 4 - Modelo CARS da Introdução de Artigos (SWALES, 1990, p. 141) 118 e 150

Figura 5 - Esquema da Sequência Didática (Em Dolz, Noverraz e Schneuwly, 2004, p. 83)

Figura 6 - Sequência Didática da Produção do Resumo ...................................................... 140

Figura 7 - Slides de PowerPoint: Resumo Acadêmico ..................................................... 141

Figura 8 - Sequência Didática da Produção da Introdução .................................................. 148

Figura 9 - Slides de PowerPoint: Pauta de Revisão ............................................................ 151

Figura 10 - Sequência Didática: Apresentação de Resultados, Discussão e Conclusão 157

Figura 11 - Síntese da organização retórica da seção de resultados e discussão (retirada de Motta-Roth e Hendges, 2010, p. 128) 158

Tabela 1 - Frequência de recursos linguísticos selecionados em seções de Artigos Acadêmicos (SWALES E FEAK, 2004, p. 223) 116

Tabela 2 - Plano de curso 135 


\section{LISTA DE GRÁFICOS}

Gráfico 1 - Questão 4: Grupo etário a que pertence 41

Gráfico 2 - Questão 8: Tempo de experiência como professor universitário 41

Gráfico 3 - Questão 9: Suas aulas são:

Gráfico 4 - Questão 10: Que metodologia você utiliza para ministrar a/s disciplina/s que leciona? É possível escolher várias alternativas.

Gráfico 5 - Questão 11: O ensino de produção de texto acadêmico ou de artigo científico é um dos objetivos da disciplina que você leciona?

Gráfico 6 - Questão 14: Você utiliza meios digitais para se comunicar com seus alunos como forma complementar de apoio às aulas presenciais?

Gráfico 7 - Questão 15: Em caso de resposta positiva à questão anterior, como se dá essa comunicação?

Gráfico 8 - Questão 17: Que atividades você realiza por meio dessa comunicação virtual? Indique, por favor, todas as alternativas que se aplicam.

Gráfico 9 - Questão 19: E no que diz respeito aos alunos, como se dá o envolvimento deles com o ambiente virtual? Indique, por favor, todas as alternativas que se aplicam. ....... 52

Gráfico 10 - Questão 4: Grupo etário a que pertence ................................................... 172

Gráfico 11 - Questão 5: Universidade em que estuda .................................................. 173

Gráfico 12 - Questão 6: Nome do curso que faz ....................................................... 174

Gráfico 13 - Questão 7: Ano de ingresso nesse curso ................................................ 174

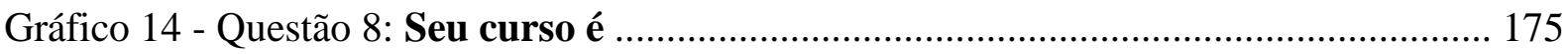

Gráfico 15 - Questão 9: No curso que frequenta no momento, você já fez ou está fazendo disciplina que envolva o ensino de produção de texto? .............................................. 176

Gráfico 16 - Questão 10: Em caso de resposta positiva à pergunta anterior, responda às questões que seguem. Qual é o nome da disciplina que você cursa/cursou? ................. 176

Gráfico 17 - Questão 12: $O$ ensino de produção de texto acadêmico (ou artigo científico) fez/faz parte das atividades desenvolvidas nessa disciplina?

Gráfico 18 - Questão 14: O professor ou monitor responsável pela disciplina utilizou meios digitais para se comunicar com os alunos fora do horário de aula presencial? ..

Gráfico 19 - Questão 15: Em caso de resposta positiva à questão anterior, quais? 181

Gráfico 20 - Questão 16: Você enfrenta algum tipo de problema por conta da utilização desses ambientes virtuais? 
Gráfico 21 - Questão 18: Você avalia positiva ou negativamente a utilização do ambiente virtual?

Gráfico 22 - Questão 19: Você acredita que todos participam igualmente das atividades desenvolvidas no ambiente virtual?

Gráfico 23 - Questão 20: Você e/ou seus colegas tiveram dificuldades no acesso ao ambiente virtual? Comente.

Gráfico 24 - Questão 21: Quanto aos resultados em termos de aprendizagem, você acredita que o curso e as atividades em ambiente virtual contribuíram para a construção de conhecimentos novos para você? 


\section{SUMÁRIO}

INTRODUÇÃO 14

\section{CAPÍTULO 1}

O ensino de escrita acadêmica na universidade - iniciativas observadas

1.1 Obras sobre escrita acadêmica no Brasil e um olhar sobre um grupo estrangeiro 27

1.2 Algumas iniciativas em universidades pesquisadas 32

1.3 Como se trata o ensino de escrita acadêmica em algumas universidades brasileiras 35

1.3.1 Metodologia e questões propostas a professores .................................................. 35

1.3.2 Tabulação de resultados: gráficos e análises de questões abertas e fechadas 40

\section{CAPÍTULO 2}

Os ambientes presenciais e virtuais de aprendizagem - estudos sobre interação e cognição

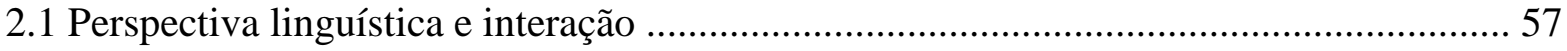

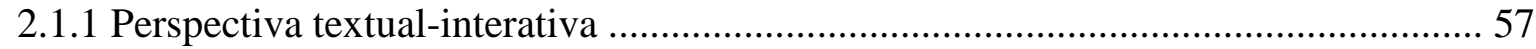

2.1.2 Interação como fenômeno e interação na sala de aula presencial ............................. 59

2.1.3 Uso das novas tecnologias na educação: interação e linguagem ............................. 63

2.1.4 Ambientes complementares de ensino: o presencial e o virtual ............................. 69

2.1.4.1 Digital ou virtual? Conceito e funcionamento de um ambiente digital ............. 71

2.1.4.2 Ambiente Virtual de Aprendizagem (AVA) - algumas possibilidades ............. 73 
2.1.5 Características complementares da interação em ambientes presenciais e virtuais e alguns resultados 76

2.1.5.1 Blended learning: combinação de atividades presenciais e virtuais na aprendizagem 82

2.2 Enfoque cognitivo 90

2.2.1 Teoria dos Espaços Mentais e Teoria da Mesclagem Conceptual (TMC) 92

\section{CAPÍTULO 3}

A teoria dos gêneros - uma opção para o ensino de produção textual

3. 1 A questão do gênero textual-discursivo 99

3.1.1 Ensinar produção textual com base na teoria dos gêneros 102

3.1.1.1 Macro, micro e superestruturas 104

3.1.1.2 Textos como Artefatos em Atividade 107

3.1.1.3 Sociorretórica de Swales 112

3.1.1.4 Escrita acadêmica em Língua Portuguesa: Motta-Roth e Hendges 118

3.1.1.5 Concepção do gênero Artigo Científico 122

3.1.2 O gênero artigo científico e as Sequências Didáticas 124

\section{CAPÍTULO 4}

\section{O artigo científico em aprendizagem combinada - sequência de atividades}

4.1 Proposta de Aprendizagem Combinada para o ensino de artigo científico

4.1.1 Plano de trabalho 
4.1.2.3 Sequência Didática da Produção de Apresentação de Resultados, Discussão e Conclusão 156

4.2 Reprodução e Análise da Tarefa de aluno Letras: Introdução e Reescrita 160

4.3 Pesquisa com alunos 168

4.3.1 Tabulação de resultados, gráficos e análises de questões propostas aos alunos 172

CONCLUSÃO 189

REFERÊNCIAS BIBLIOGRÁFICAS 195

\section{ANEXOS}

ANEXO A - Corpus de Consulta 203

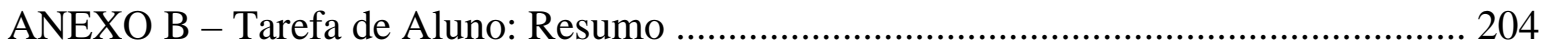

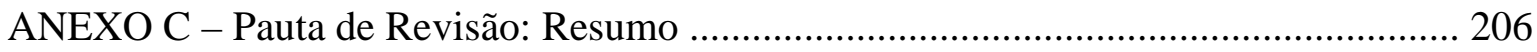

ANEXO D - Tarefa de aluno Estatística: Introdução e Reescrita com Resumo .............. 208

ANEXO E - Tarefa de aluno Letras: Introdução e Reescrita ........................................ 212

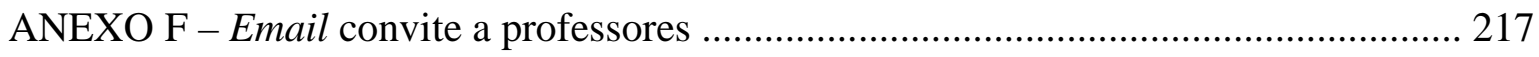

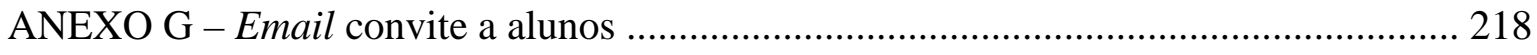

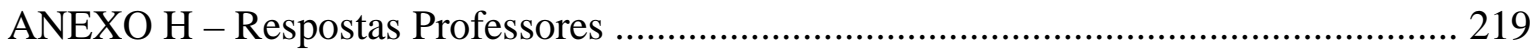

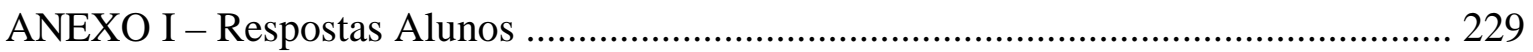




\section{INTRODUÇÃO}


O crescimento do acesso à tecnologia, seja ela representada pela internet, pelas redes sociais ou pelas plataformas virtuais de educação, amplia consideravelmente a participação dos indivíduos na circulação de conteúdos e na construção do conhecimento, além de fazer emergirem novas habilidades e competências, circunstâncias que não podem passar despercebidas pela escola. Swales e Feak (2012) incluem-se entre os pesquisadores que consideram a atividade acadêmica mais cooperativa hoje do que costumava ser, em decorrência da universalização das novas tecnologias de comunicação e da consequente expansão das possibilidades de conexão e colaboração virtual.

Tal circunstância influencia profundamente a veiculação do discurso das áreas acadêmicas, em que há a necessidade de divulgação e consolidação do conhecimento científico por meio da leitura e da produção escrita de diversos gêneros textuais. Nesse sentido, o estudo e as atividades de pesquisa no ensino superior demandam dos estudantes e pesquisadores o desenvolvimento de competências em termos de leitura e escrita que nem sempre se podem transferir de experiências anteriores de aprendizagem, situação também reconhecida por Castelló et al. (2012, p. 572) em estudos que questionaram professores de universidades espanholas e que levaram à reflexão sobre a necessidade de ensinar escrita acadêmica.

No Brasil, o cenário universitário sofre alterações que têm o propósito de promover a democratização do acesso às universidades, por meio da criação de políticas públicas de inclusão social pelo Ministério da Educação (ME) que incluem programas como o PROUNI ${ }^{1}$, que concede bolsas de estudo em universidades privadas, e o $\mathrm{FIES}^{2}$, que financia a graduação em cursos superiores, para estudantes com avaliação positiva no ENEM (Exame Nacional do Ensino Médio), uma prova de acesso ao ensino superior brasileiro que contou, em 2015, com a inscrição de 7.746 .118 participantes. ${ }^{3}$

\footnotetext{
${ }^{1}$ Segundo informações obtidas no seu site oficial, http://siteprouni.mec.gov.br/, o PROUNI "É o programa do Ministério da Educação, criado pela Lei $\mathrm{n}^{\circ}$ 11.096, de 13 de janeiro de 2005, que concede bolsas de estudo integrais e parciais de 50\% em instituições privadas de educação superior, em cursos de graduação e sequenciais de formação específica, a estudantes brasileiros sem diploma de nível superior.“

2 Conforme informações no site http://sisfiesportal.mec.gov.br/ , (acesso em 02/05/2016) "O Fundo de Financiamento Estudantil (Fies) é um programa do Ministério da Educação destinado a financiar a graduação na educação superior de estudantes matriculados em cursos superiores não gratuitas na forma da Lei 10.260/2001. Podem recorrer ao financiamento os estudantes matriculados em cursos superiores que tenham avaliação positiva nos processos conduzidos pelo Ministério da Educação."

${ }^{3}$ Informação obtida por meio do link http://www.brasil.gov.br/educacao/2015/10/enem-a-segunda-maior-provade-acesso-ao-ensino-superior-do-mundo (acesso em 02/05/2016)
} 
Por outro lado, segundo informações do INEP (Instituto Nacional de Estudos e Pesquisas Educacionais Anísio Teixeira), instituição responsável pela organização e aplicação do ENEM, entre os alunos que prestaram o exame em 2014, houve uma significativa diminuição no desempenho na prova de redação em relação aos candidatos do ano anterior. ${ }^{4}$ Tal informação pode ser considerada um alerta de que o desempenho linguístico dos ingressantes na universidade precisa ser observado com mais atenção, em vista de que haverá novas demandas em termos de leitura e escrita no ensino superior, que deverão ser supridas para que seu desempenho acadêmico seja satisfatório.

Em geral, um estudante que ingressa no ensino superior confronta-se com a necessidade de fazer a revisão da bibliografia sobre tema de interesse para sua formação universitária, de ler e resumir textos de aprofundamento teórico ou de escrever monografias ou artigos que expressem o andamento de seus estudos. Para que realize tais tarefas, é preciso que desenvolva competências mais complexas com vistas à produção textual, que podem levá-lo a refletir tanto sobre o próprio processo de produção escrita quanto a respeito do novo conhecimento obtido na área que escolheu.

Além de favorecer o aluno a participar mais ativamente de seu processo educativo, aprender, durante sua graduação, a produzir textos acadêmicos como o artigo científico - um gênero escrito para relatar um estudo ou pesquisa mais pontual, mas cuja estrutura textual guarda bastante semelhança com outros gêneros acadêmicos mais complexos - pode preparar o estudante para produzir o Trabalho de Conclusão de Graduação, a Dissertação de Mestrado ou a Tese de Doutorado, tarefas que ele terá que cumprir ao longo de sua vida acadêmica para poder ingressar na comunidade científica de sua área de estudo. Por outro lado, a reflexão que a produção textual escrita exige incide também no conhecimento adquirido, pois comunicá-lo implica refletir sobre ele.

A consideração das circunstâncias mencionadas permite observar a necessidade de valorização do ensino de escrita acadêmica no Brasil, em concordância com o que já ocorre em diversas universidades pelo mundo, como as pesquisas do grupo de Castelló e Donahue (2012) e a criação de instituições acadêmicas destinadas ao ensino de escrita, como o 'Instituto Dartmouth de Escrita e Retórica'5 , entre outras iniciativas. São já indícios dessa

\footnotetext{
4 Informação obtida por meio do link: http://www.brasil.gov.br/educacao/2015/01/mec-e-inep-apresentamresultados-do-enem-2014 (acesso em 02/05/2016).

5 Tradução livre de 'Dartmouth Institute for Writing and Rhetoric' , uma instituição dedicada a ajudar membros do Dartmouth College, universidade americana, a desenvolver estratégias para organizar ideias, encontrar fontes
} 
valorização o aumento na oferta de cursos livres ou de extensão sobre o assunto, em centros universitários como a Universidade de São Paulo - USP e a Universidade Estadual de Campinas - UNICAMP, e a recente publicação de diversas obras sobre o tema como as de Ferrarezi Jr. (2013), Machado, Motta-Roth e Hendges (2010), Lousada e Abreu-Tardelli (2005), além das várias reedições de Severino (2007), entre outros, todos eles autores que se dedicam a propor metodologias para a realização de pesquisa científica e sua expressão escrita por meio dos diversos gêneros textuais acadêmicos.

Embora tenhamos notícia de tais iniciativas para atender à demanda de orientações sobre escrita acadêmica em universidades brasileiras, consideramos que elas são insuficientes, seja pela pouca frequência com que ocorrem, seja por não estarem inseridas oficialmente nos cursos e, como consequência, não serem planejadas de maneira integrada às graduações. Esta informação decorre da observação da instituição em que realizamos esta pesquisa, na qual ingressam anualmente na graduação de Letras um número médio de setecentos alunos ${ }^{6} \mathrm{em}$ busca do Bacharelado, sempre com habilitação em Português. Não são oferecidas a esses alunos disciplinas que abordem especificamente a produção de texto acadêmico, nem cursos de extensão frequentes sobre o tema. Podemos ainda afirmar que, conforme nossa observação durante os estudos realizados para esta pesquisa, quando há oferta de tais cursos de extensão, as inscrições superam o número de vagas ${ }^{7}$, indicando que ainda há interesses não atendidos. Além disso, os cursos oferecidos fazem-se de modo presencial.

Tendo em vista esse contexto, problematizamos: A inserção de uma disciplina ou curso voltados ao ensino de texto acadêmico em Língua Portuguesa poderia trazer resultados significativos em termos de aprendizagem para alunos de graduação? Em relação à produção de gêneros do domínio acadêmico, justifica-se uma proposta de ensino que combine atividades desenvolvidas em ambientes presenciais e virtuais? Por quê?

Temos por hipótese que o ensino de produção textual acadêmica em língua materna não só promove a aquisição/o desenvolvimento de competências necessárias aos estudos acadêmicos, mas também auxilia a construção de conhecimentos específicos da área

de pesquisa apresentar e revisar produções escritas das mais diversas. Conforme informações encontradas em: http://writing-speech.dartmouth.edu/ (Acesso em 02/05/2016).

${ }^{6}$ Segundo informações obtidas nos Manuais do candidato FUVEST 2015 e 2016, publicados no site oficial da FUVEST, http://www.fuvest.br/, foram oferecidas 849 vagas em 2015 e 679 em 2016 para ingresso no curso de Letras.

${ }^{7}$ Quando foi oferecido pela primeira vez na FFLCH-USP, no primeiro semestre de 2015, o curso "Leitura e escrita de textos conceituais em humanidades. Práticas para a formação dos alunos de graduação e das licenciaturas da FFLCH" recebeu mais de trezentas inscrições para as cinquenta vagas abertas. 
escolhida, numa relação dialógica. Outra hipótese refere-se ao fato de que, entre as possíveis práticas educativas adotadas para o ensino de produção de texto acadêmico, há algumas mais adequadas aos ambientes presenciais, enquanto outras se ajustam mais aos ambientes virtuais de aprendizagem. Por fim, testaremos a hipótese de que a combinação de atividades didáticas desenvolvidas em ambientes presenciais e virtuais, tendo em vista a interação diversa e complementar promovida nesses dois meios, aumenta as possibilidades de articulações cognitivas e pode permitir uma construção de conhecimento mais significativo.

Buscamos, assim, defender a tese de que ensinar texto acadêmico em Língua Portuguesa mediante a combinação de atividades realizadas em ambientes virtuais e presenciais pode propiciar resultados de aprendizagem mais significativos do que se fosse usado apenas um ambiente de ensino, tanto em termos de desenvolvimento de competências linguísticas, discursivas e textuais ${ }^{8}$, como de construção de conhecimentos acadêmicos específicos de uma área, desde que essa combinação seja criteriosamente planejada em termos interativos, cognitivos e didáticos.

As hipóteses que levantamos permitem-nos apresentar os seguintes objetivos:

1. Examinar como se dá a interação e a construção de conhecimentos por meio da linguagem em ambientes presenciais e virtuais, para determinar a importância das abordagens multimodais na promoção da aprendizagem, tendo em vista, então, um viés cognitivo.

2. Apresentar uma proposta de ensino que combine atividades desenvolvidas em ambientes presenciais e virtuais e observar como fundamentos da teoria dos gêneros podem contribuir para justificá-la.

3. Estabelecer quais práticas em ambientes presenciais e virtuais podem ser mais adequadas para a aprendizagem de gêneros textuais-discursivos do domínio acadêmico em Língua Portuguesa, especificamente o artigo científico.

4. Descrever o cenário em que hoje se insere o ensino de produção textual na universidade brasileira, para justificar a proposta de inclusão de disciplinas e

\footnotetext{
${ }^{8}$ O termo "competências" foi adotado no sentido encontrado em Fiorin (1996), que enumera as competências linguísticas, discursivas e textuais entre os conhecimentos internalizados de que o sujeito precisa para enunciar.
} 
cursos sobre produção de texto acadêmico em Língua Portuguesa na graduação, nas diversas áreas do conhecimento.

Para alcançarmos esses objetivos, propomos, metodologicamente, as seguintes ações de pesquisa: uma investigação teórica com base na literatura de referência sobre interação, cognição, ensino de produção de texto acadêmico e ambientes de aprendizagem; uma investigação de caráter etnográfico com observação participante por meio da aplicação de uma proposta de ensino que envolve uma concepção particular do gênero artigo científico e a combinação de atividades em ambientes presenciais e virtuais; um questionamento a professores da área de ensino de produção textual; e um questionamento a alunos que participaram das aplicações dessa proposta.

A abordagem metodológica que este estudo sobre ensino de texto acadêmico adota alinha-se a algumas tendências atuais do campo de estudo da Linguística Aplicada (LA) que, segundo Lopes-Rossi (2009, p. 4), instituiu-se como área de pesquisa a partir dos anos 60, quando aumentou, entre os linguistas, a preocupação com o ensino de línguas, maternas ou estrangeiras. Atualmente, a LA emprega uma visão interdisciplinar para a solução de problemas decorrentes dos vários usos da linguagem, integrando áreas como Educação, Psicologia Cognitiva, Sociologia, Comunicação Social e a própria Linguística, no sentido mais particular de estudo de aspectos formais e estruturais da língua.

Lopes-Rossi (2009), ao retomar os métodos investigativos da Linguística Aplicada, cita como tendência mais moderna, segundo classificação de Moita Lopes (1996, p. 86), as pesquisas que enfocam o processo de ensinar/aprender conforme realizado em sala de aula, com dois tipos básicos: de diagnóstico ou intervenção. Esse último tende à pesquisa qualitativa, voltada aos processos sociointeracionais envolvidos na construção do conhecimento e com foco no uso da linguagem. De natureza etnográfica, a partir de observação participante, a pesquisa de intervenção pode ser realizada pelo próprio professor e seu objetivo é investigar a possibilidade de se modificar uma situação existente. É também chamada pesquisa-ação. (LOPES-ROSSI, 2009, p. 10)

Vinculando-se, de certa maneira, aos procedimentos metodológicos de diagnóstico e intervenção, o presente estudo baseia-se na observação participante da aplicação de proposta pedagógica que combina atividades desenvolvidas nas modalidades presencial e virtual, com o objetivo de sugerir novas possibilidades para o ensino, na universidade, de produção do artigo científico, aqui tomado como gênero textual-discursivo. 
Motta-Roth (2011, p. 169) afirma que, na investigação da linguagem como gênero, evidencia-se a relação dialética entre texto e contexto, "de tal sorte que a interpretação do texto (linguagem) depende da compreensão das condições do contexto (sociedade) e viceversa". Ao sugerir procedimentos investigativos, Motta-Roth (2011) indica a possibilidade de eles serem articulados de acordo com as necessidades evidenciadas pelo contexto e pelos textos estudados, num fluxo contínuo. Motta-Roth (2011) afirma:

A pesquisa da linguagem como gênero se constitui em um processo cíclico de interpretação com base na literatura de referência (teoria GERAL), no estudo dos textos, na teoria do pesquisador (teoria LOCAL) e no depoimento de entrevistados, participantes da interação. (MOTTA-ROTH, 2011, p. 167)

Nesta pesquisa, por concordamos em grande medida com Motta-Roth (2011), selecionamos, do ensino de produção de textos que pertencem ao domínio/esfera do Discurso Acadêmico, o gênero artigo científico, incluindo sua linguagem e o contexto social em que está inserido, como nosso objeto de estudo. Examinamos o panorama do ensino de escrita acadêmica na universidade, no Brasil e em alguns outros países, para observar esse gênero em um contexto de situação e de cultura para perceber sua função. Também entrevistamos membros da comunidade docente da área de ensino de produção textual para confirmar procedimentos e interpretações que esses profissionais adotam em sua prática de ensino.

Revisamos a literatura em busca de pesquisa prévia sobre ambientes presenciais e virtuais de aprendizagem e também a respeito de como se dá a interação e a construção de conhecimento nesses meios. Investigamos fundamentos teóricos sobre práticas de ensino de produção textual por meio de gêneros, por identificarmos nelas um procedimento didático adequado ao ensino do artigo científico. Observamos empiricamente um corpus representativo do artigo científico para elaborar uma concepção didática desse gênero em termos de tendências de estrutura e de linguagem, com o propósito de organizar uma proposta de ensino que combinasse atividades desenvolvidas em ambientes presenciais e virtuais de aprendizagem.

Realizamos aplicações dessa proposta e assim desenvolvemos uma pesquisa de caráter etnográfico com observação participante, que nos possibilitou diagnosticar adequações e dificuldades e intervir no processo de ensinar, buscando torná-lo mais eficiente, conforme os resultados das práticas escolhidas. Para conhecer a opinião dos estudantes, convidamos os participantes das aplicações da proposta a responderem a uma pesquisa sobre sua experiência 
com ensino de escrita acadêmica e a utilização de meios presenciais e virtuais de aprendizagem.

Especialmente em relação à proposta combinada de ensino de artigo científico em Língua Portuguesa, ela foi aplicada em duas ocasiões sucessivas, em cursos distintos, o que permitiu fazer adequações e aperfeiçoamentos conforme os estudos sobre aspectos pedagógicos, interacionais e cognitivos avançavam, procurando encontrar sequências didáticas mais ajustadas, definir quais práticas seriam mais adequadas ao ambiente presencial ou ao virtual, numa contínua reconfiguração a depender do curso e da turma de alunos. Contribui também para tais ajustes a organização das Pautas de Revisão, elaboradas a partir dos comentários individuais sobre as tarefas dos alunos, em cada fase do processo de produção do artigo científico.

A primeira ocasião em que se aplicou uma versão dessa proposta ocorreu no segundo semestre de 2012, com a monitoria tanto das aulas presenciais como da interação virtual por meio de grupo Google de e-mails da disciplina obrigatória FLC 0474 - Língua Portuguesa no Instituto de Matemática e Estatística da Universidade de São Paulo, IME-USP.

A turma era formada, quase exclusivamente, por alunos provenientes de turmas em diferentes estágios do curso de Estatística. Houve inicialmente cinquenta e seis inscritos, nove desistentes por motivos vários e quarenta e sete concluintes. O curso, desenvolvido, planejado e constantemente replanejado de acordo com as características dos participantes e o feedback recebido a cada aula e a cada atividade, tinha o objetivo de abordar as características composicionais de diversos gêneros acadêmicos, como o Resumo, a Resenha, o Relatório (visto que era esperado desses alunos que produzissem um documento desse gênero ao final de seu curso) e, em especial o Artigo Científico.

Com relação a este último, a produção individual de artigo referente a uma pesquisa realizada ou à revisão bibliográfica sobre temas relativos a Estatística foi proposta, como processo construído durante todas as aulas do curso, constituindo um dos critérios, o de maior peso, para a avaliação da disciplina.

Como forma de interação virtual, optou-se pela formação de um grupo de emails no Google, um ambiente não específico de aprendizagem, mas que consideramos ter proporcionado suficiente interação tanto em questão de troca de mensagens entre os participantes, como na postagem, revisão e devolução de textos escritos pelos alunos nos vários estágios da citada produção do artigo científico. Em 01/09/2015, o acesso a esse grupo 
de emails compartilhado publicamente ainda podia ser feito por meio do link: https://groups.google.com/forum/?hl=pt-BR\#!forum/flc0474.

A segunda aplicação ocorreu na disciplina optativa livre FLC1261 - Leitura e Produção de Textos II do curso de Letras da Faculdade de Filosofia, Letras e Ciências Humanas da USP, e constitui-se de aulas presenciais ministradas, no segundo semestre de 2013, pela Profa. Dra. Zilda Gaspar Oliveira de Aquino com a nossa colaboração na gestão do ambiente virtual de apoio à disciplina, o Moodle USP do Stoa. As atividades desenvolvidas presencial e virtualmente apontam para um enfoque mais particular, nesta versão, da produção propriamente dita do artigo científico, apesar de também se apresentarem outros gêneros do discurso acadêmico, como Resumos e Resenhas.

As aulas foram frequentadas por alunos de diferentes estágios do curso de Letras e houve um total inicial de vinte e um inscritos no curso e na plataforma virtual. Como ambiente de interação virtual foi adotado o Moodle USP do Stoa, definido como "um ambiente virtual de aprendizagem em apoio às disciplinas da USP" na seção 'SOBRE' do site em que esse ambiente está ancorado (http://disciplinas.stoa.usp.br/). O ambiente ainda estava ativo em 01/09/2015, porém o acesso à página da disciplina só é permitido mediante cadastro e utilização de senha. Segundo informações da mesma seção, o projeto Stoa é uma iniciativa do STI - Superintendência de Tecnologia da Informação, sendo o CCE - Centro de competência de Software Livre da IME e o Grupo ATP - Apoio Técnico Pedagógico os responsáveis pela realização, manutenção e operacionalização do serviço.

Ao final da aplicação das duas versões da proposta de aprendizagem combinada, foram organizados, e aplicados via ambiente virtual, questionários para conhecer a opinião de alunos que preferencialmente haviam participado de uma das aplicações da proposta, sobre as práticas utilizadas para o ensino desses gêneros e sobre o uso de meios virtuais como suporte a essas práticas. A descrição da proposta, das perguntas feitas aos alunos e as considerações sobre os resultados obtidos na referida pesquisa encontram-se no Capítulo 4.

De maneira a configurar uma base teórica adequada para a elaboração e a aplicação da citada proposta de ensino de produção textual, procuramos mobilizar e relacionar diversos construtos teóricos referentes aos campos dos Estudos Linguísticos, do uso das Novas Tecnologias na Educação, da Cognição, da Interação e dos Procedimentos Didáticos em Ambientes Presenciais e Virtuais de Aprendizagem. Também pesquisamos a Aprendizagem Combinada, ou Blended Learning, e as teorias de Ensino dos Gêneros textuais-discursivos centradas no artigo científico. 
É preciso ressaltar, entretanto, que o foco principal nesta pesquisa volta-se aos estudos linguísticos, em sua compreensão ampla, e o que norteia nossos estudos é a concepção, proposta por Marcuschi (2008, p. 64), de língua como atividade social, interativa, histórica e cognitiva, desenvolvida de acordo com as práticas socioculturais. Este estudioso ainda acrescenta que tal atividade pode assumir a importante função de inserir indivíduos em contextos socio-históricos e permitir que se entendam. Tendo em vista essa concepção de linguagem interativa e contextualizada, consideramos adequada a nossa posição de selecionar o gênero (no nosso caso o artigo acadêmico) como objeto de pesquisa, a partir do que indicam, entre outros autores, Marcuschi (2008, 2011) e Dolz, Gagnon e Decândio (2010), que veem o gênero como instrumento didático importante para o ensino de produção textual.

Segundo Dolz, Gagnon e Decândio (2010, p. 44), ao mediar as interações indivíduosobjetos e agir como meio de articulação entre as práticas sociais e os objetos escolares, o gênero é instrumento de aprendizagem que permite acesso a significações que contribuem para o desenvolvimento das capacidades linguageiras do aprendiz. Selecionamos também articular as teorias sobre ensino de gêneros com o procedimento denominado Sequência Didática, proposto por Dolz e Schneuwly (2004, p. 43), que consiste de uma "sequência de módulos de ensino, organizados conjuntamente para melhorar uma determinada prática de linguagem.".

A opção por considerar, em nossa proposta de ensino, a produção de texto acadêmico em Língua Portuguesa, embora saibamos da atual tendência à publicação em Língua Inglesa nas várias áreas do conhecimento, deve-se à nossa hipótese de que o ensino de produção textual em língua materna não só promove a aquisição/o desenvolvimento de competências linguísticas, discursivas e textuais necessárias aos estudos acadêmicos, mas também auxilia a construção de conhecimentos acadêmicos específicos da área escolhida, numa relação dialógica, como já o dissemos. Concebemos o ensino de produção textual em Língua Portuguesa no ensino superior brasileiro como promotor tanto da aprendizagem da produção do texto acadêmico, quanto de uma atitude mais construtiva e reflexiva sobre a construção dos conhecimentos acadêmicos em geral. Estamos de acordo, portanto, com Marcuschi (2008, p. 64) quando esse estudioso afirma que "a língua é uma atividade interativa, social e mental que estrutura nosso conhecimento e permite que nosso conhecimento seja estruturado".

Para contribuir com esta pesquisa sobre ensino de produção textual em ambientes presenciais e virtuais, procuramos conhecer um pouco mais sobre as tecnologias da informação e comunicação, as TICs, e o impacto que elas têm sobre a cena didática, na 
tentativa de descobrir como seu uso pode favorecer a interação na aprendizagem, pois cremos, em consonância com outros estudiosos, que é na interação que se constroem o sentido e, em última instância, o conhecimento. Nessa direção, estudamos, em Paiva (2001) e Paiva e Rodrigues Jr, (2004), as características dos ambientes presenciais e virtuais de aprendizagem, e, em Haythornthwaite e Andrews, (2011), as funcionalidades da comunicação mediada por computador, diferenciando-as daquelas da comunicação face a face, para observar questões de interação e cognição.

Numa visão mais particular e sintetizada das ideias dos citados autores, com vistas a adaptá-las à proposta de ensino do artigo científico, tomamos por base que, na interação presencial, em geral os participantes se encontram no mesmo espaço geográfico, há sincronia temporal, o tempo da interação é limitado e a participação dos interlocutores é linear. Em contrapartida, na interação virtual, os participantes na maioria das vezes estão geograficamente dispersos, há assincronia temporal, o tempo de participação é aumentado e a participação é não-linear, o que permite sugerir que tempo e espaço são expandidos no ambiente virtual.

Por considerarmos que o conceito de aula foi ampliado pelas novas tecnologias, é possível dizer que também se intensificou a interação no 'lugar' em que ela acontece, agora integrando o presencial e o virtual. Segundo Silva (2002, p. 179), na sala de aula, o individual e o social estão em contínua articulação, e os sujeitos - professores e alunos - mediados pela linguagem, negociam e constroem o sentido do mundo. Uma proposta de ensino de produção textual que inclua atividades desenvolvidas conjuntamente e de forma integrada em ambientes presenciais e virtuais ajusta-se à hipótese de que a interação promovida nesses dois ambientes, por ser diversa e complementar, pode aumentar a eficiência das operações cognitivas a serem realizadas para a produção do artigo científico.

Essa integração de atividades alinha-se às bases teóricas da blended learning (aprendizagem combinada, mista ou híbrida), propostas por Garrison (2011 [2003]), que afirma que a total integração de atividades presenciais e virtuais pode ser uma resposta para o desafio de envolver alunos da educação superior num processo de aprendizagem mais participativo e, portanto, mais significativo.

Observamos ainda os aspectos cognitivos que envolvem o ensino de produção textual, ao levar em conta os pressupostos da Linguística Cognitiva (LC), expressos por Silva (2004, p. 2), sobre ser a interação com o mundo mediada por estruturas como a linguagem - cuja função básica é a categorização - tomada como meio de interpretar e construir tal mundo, de 
organizar conhecimentos que refletem as necessidades, os interesses e as experiências dos indivíduos e das culturas. Também nos interessamos por conhecer o mapeamento conceitual que os sujeitos fazem ao processar textos, seja por meio da leitura ou da escrita, conforme afirma Militão (2009) ao citar a Teoria da Mesclagem Conceitual de Fauconnier e Turner (2002), dizendo que a cognição integra sistemas como a linguagem, a estrutura sociocultural, nosso corpo e nossas interações com o mundo.

O desenvolvimento desta pesquisa apresenta-se organizado nos seguintes capítulos:

- Capítulo 1 - O ensino de escrita acadêmica na universidade - iniciativas observadas

- Capítulo 2 - Os ambientes presenciais e virtuais de aprendizagem - estudos sobre interação e cognição

- Capítulo 3 - A teoria dos gêneros - uma opção para o ensino de produção textual

- Capítulo 4 - O artigo científico em aprendizagem combinada - sequência de atividades

Em seguida às Referências, encontra-se a seção de ANEXOS, que se constituem do Corpus de Consulta, de Tarefas de alunos, de uma Pauta de Revisão, de emails enviados a professores e alunos e das respostas de professores e alunos às pesquisas realizadas. 


\section{CAPÍTULO 1}

\section{O ensino de escrita}

acadêmica na

universidade -

iniciativas observadas 
O presente estudo tem como base o conceito de que um dos principais objetivos da escola como lugar de transmissão de saberes é ensinar sistematicamente a língua materna, seja na modalidade escrita ou oral, abordando variedades formais e coloquiais, em todos os níveis de ensino, do fundamental ao superior. Além disso, adota a concepção proposta por Marcuschi (2008, p. 64) de língua como "atividade social, histórica e cognitiva, desenvolvida de acordo com as práticas socioculturais" e "atividade interativa, social e mental que estrutura nosso conhecimento e permite que nosso conhecimento seja estruturado".

Isso posto e aplicado na conjuntura em que se pretende situar a proposta de ensino de produção de texto deste estudo - o ensino de artigo científico no ensino superior - permite dizer que essa atividade linguística de produção textual considera práticas socioculturais próprias do ensino universitário, fundamentado em pesquisa e produção de conhecimento científico, e a propõe como base para aquisição não só de competências linguísticas, mas também de conhecimento acadêmico de outras ordens, conforme a área escolhida pelo estudante.

Apresentam-se, a seguir, algumas observações sobre o cenário em que se insere o atual ensino de texto acadêmico, seja por meio de um levantamento da posição de alguns autores nacionais e estrangeiros sobre o tema - expressa em obras publicadas recentemente -, seja pelo relato de algumas iniciativas de promover o ensino de texto acadêmico de que se teve notícia no decorrer desta pesquisa. Os resultados de um questionário dirigido a professores envolvidos com a produção de escrita acadêmica na universidade brasileira completam o capítulo.

1.1. Obras sobre escrita acadêmica no Brasil e um olhar sobre um grupo estrangeiro

Grande parte dos pesquisadores brasileiros que se dedicam a estudar o ensino de escrita acadêmica na universidade concorda com a afirmação de que é principalmente por meio da produção de textos acadêmicos que os alunos e pesquisadores podem expressar o progresso de seus estudos e pesquisas, exercer atividades de iniciação ao procedimento científico (SEVERINO, 2007, p. 26) ou ainda comprovar as competências adquiridas pelos estudantes no decorrer da vida acadêmica (FERRAREZI JR., 2013, p. 9), com a elaboração, por exemplo, de um trabalho de conclusão de curso. 
Por outro lado, dados colhidos no site do Portal Brasil (disponível em http://www.brasil.gov.br/educacao/2015/01/mec-e-inep-apresentam-resultados-do-enem2014, acesso em 19/01/2016) sobre resultados do Exame Nacional do Ensino Médio (ENEM) de 2014, apontam para uma queda significativa, de 2013 para 2014, no desempenho em redação dos alunos concluintes do Ensino Médio, os mais prováveis candidatos ao ingresso na universidade. Segundo o INEP (Instituto Nacional de Estudos e Pesquisas Educacionais Anísio Teixeira) - uma autarquia federal vinculada ao Ministério da Educação (MEC) que promove estudos, pesquisas e avaliações sobre o Sistema Educacional Brasileiro -, os candidatos concluintes do Ensino Médio que prestaram o exame em 2014 tiveram uma diminuição de $9,7 \%$ no seu desempenho na prova de Redação em comparação aos do ano anterior nessa mesma condição.

Além de levar em conta o fato de que a produção textual no ensino superior se refere preferencialmente a gêneros textuais-discursivos acadêmicos, diferentes daqueles estudados e produzidos nos Ensinos Fundamental e Médio, a informação do INEP sobre a queda de desempenho em Redação sugere que é preciso observar com atenção o desempenho linguístico de considerável parcela de ingressantes na universidade, pois seu despreparo em leitura, interpretação e produção de textos, antes mesmo de chegar à universidade, pode ser motivo de desfavorecimento no nível superior.

Tal circunstância de despreparo que acompanha o calouro universitário é provavelmente uma das causas da situação observada por pesquisadoras como Machado, Lousada e Abreu-Tardelli (2005, p. 13), ao justificarem sua colaboração aos estudos sobre gêneros acadêmicos pela "constatação das crescentes dificuldades que os alunos dos cursos de graduação e até mesmo de mestrado e de doutorado encontram quando se defrontam com a necessidade de produzir textos pertencentes a gêneros da esfera tipicamente acadêmica e/ou científica." Essas autoras apontam como motivo maior dessas dificuldades a falta de ensino sistemático desses gêneros, adotando em suas obras estratégias específicas de leitura e atividades que objetivam desenvolver, entre outras capacidades, a do planejamento em relação a textos acadêmicos diversos.

Motta-Roth e Hendges (2010, p. 13) citam o ditado "Publique ou pereça!", tradução do "Publish or perish!" das universidades americanas, que faz alusão à pressão que sofrem alunos, professores e pesquisadores universitários para escrever e publicar textos acadêmicos de qualidade, com o propósito de conquistar e assegurar bolsas de estudo e espaço profissional. Em obra dedicada ao tema da redação acadêmica de que falaremos com mais 
detalhes no Capítulo 3, as autoras utilizam a abordagem sociorretórica de John M. Swales (1990), que compara os movimentos retóricos do texto para persuadir o leitor a movimentos de um jogo de xadrez, e pretendem atender à necessidade de professores de redação acadêmica de contar com um material sistematizado. (MOTTA-ROTH e HENDGES, 2010, p. 83)

Severino (2007), em obra que aborda aspectos metodológicos do trabalho científico, no momento em sua $23^{\text {a }}$. edição, defende a postura investigativa sistemática mediante procedimentos apoiados na competência tecnocientífica como forma de melhorar $o$ desempenho do processo de ensino-aprendizagem do ensino superior brasileiro. O autor parte do princípio de que a construção do conhecimento envolve três dimensões: epistemológica, metodológica e técnica, "perspectivas que deveriam ser apresentadas conjuntamente para que a iniciação científica dos estudantes não ficasse incompleta." A obra traz orientações sobre estudo, documentação e metodologias de pesquisa e aborda ainda aspectos técnicos e metodológicos da elaboração de projetos de pesquisa, monografias e outros gêneros acadêmicos como resumos e resenhas. (SEVERINO, 2007, p. 13)

Ferrarezi Jr. (2013) justifica a publicação de sua obra - escrita com base nas próprias experiências de orientações de trabalhos de graduação e pós-graduação - pelo processo de democratização do ensino superior ocorrido recentemente, inclusive com o auxílio dos programas de Educação a Distância, o que promoveu o acesso de milhares de pessoas a esses níveis de estudo. Segundo o autor, para comprovar as competências adquiridas nessas atividades acadêmicas, exige-se a elaboração de um trabalho final escrito, para a qual muitos alunos não recebem as informações necessárias, levando alguns ao fracasso. Ferrarezi Jr. apresenta informações sobre o "passo a passo" da elaboração de artigos, monografias, dissertações e teses, ilustrando-as "com exemplos retirados de trabalhos reais, elaborados nas mais diversas áreas de pesquisa, apresentados e aprovados em boas instituições brasileiras. " (FERRAREZI JR., 2013, p. 10)

Tais obras de autores nacionais representam uma pequena, porém significativa e atual amostra de como vem aumentando o interesse por publicações sobre o ensino de escrita acadêmica em nosso país, visto que, segundo os autores citados, a democratização do Ensino Superior em nosso país trouxe à universidade um estudante que nem sempre está bem preparado para produzir os gêneros acadêmicos. Outra observação a respeito das propostas de tais autores é que, a princípio, elas se destinam a ser adotadas apenas em ambiente presencial - como no caso da abordagem da produção do Resumo Acadêmico no Capítulo 4, em que se 
utiliza a teoria proposta por Motta-Roth e Hendges (2010) -, o que não impede que sejam aproveitadas neste estudo, que propõe uma abordagem combinada de práticas presenciais e virtuais.

Ainda sobre estudos que contemplam o ensino de texto acadêmico, parece relevante citar Castelló e Donahue (2012), pesquisadoras espanhola e americana, respectivamente, que se dedicam há muito tempo a estudar a produção de escrita acadêmica em suas instituições. As autoras já organizaram obra que aborda, em capítulos escritos por pesquisadores americanos e europeus, especificamente o ensino de produção escrita de universitários, apresentando novas tendências em diferentes perspectivas teóricas - sociais, culturais e cognitivas - e as práticas relevantes para a natureza situada da atividade de escrita no ensino superior delas derivadas. Algumas dessas bases teóricas, por coincidirem com a orientação da proposta deste estudo, serão retomadas mais adiante, no Capítulo 3. Em princípio, tais autoras defendem a ideia de que o processo de ensinar/produzir textos acadêmicos é forma de promover uma aprendizagem mais ativa, construtiva e reflexiva. (CASTELLÓ \& DONAHUE, 2012, p. xv)

Castelló (2012), ao introduzir a referida obra, comenta o contexto universitário europeu após a assinatura da Declaração de Bolonha, em 1999, que pedia por mudanças estruturais e metodológicas no ensino superior para que os alunos desenvolvessem uma aprendizagem mais ativa, obtendo competências complexas, o que permitiria sua mobilidade pelas universidades europeias. Confrontados com tais demandas e tendo verificado a necessidade de promover a consciência e a reflexão dos alunos sobre o próprio aprendizado, os professores europeus constataram a necessidade de desenvolver estratégias de ensino que auxiliassem a construção do novo conhecimento. Para a autora, "Quando adequadamente tratadas, essas novas demandas são frequentemente atendidas por meio do aprimoramento da escrita dos alunos, que é usada como uma forma de eles mostrarem seu processo de aprendizagem durante os cursos"9. (CASTELLÓ \& DONAHUE, 2012, p. xv)

Em estudo contemporâneo à obra anterior publicado por Castelló et al. (2012, p. 572), esse grupo de autores considera que entrar na universidade envolve tornar-se parte da comunidade acadêmica, em que os calouros são confrontados com novas demandas em termos de leitura e escrita que requerem competências não necessariamente transferíveis de

\footnotetext{
${ }^{9}$ Tadução livre de: "When adequately addressed, these new demands are frequently met by means of increasing students' writing, which is used as a way for them to show their learning process during the courses, (...)" (CASTELLÓ \& DONAHUE, 2012, p. xv)
} 
experiências de aprendizagem anteriores. Esse grupo realizou um estudo descritivo enfocando as percepções dos professores das universidades espanholas com respeito à importância da escrita acadêmica em promover a aprendizagem, o grau de competência que eles atribuem à escrita acadêmica em comparação a outras competências acadêmicas, as tarefas de escrita acadêmica mais solicitadas e os critérios mais usados para avaliar a qualidade do texto acadêmico.

Algumas conclusões sobre como se dá a escrita na universidade espanhola a que o grupo de autores chegou após tal estudo parecem bastante semelhantes ao cenário que encontramos em universidades brasileiras, ao pesquisarmos o tema, conforme resultados de investigação que será apresentada mais adiante, neste capítulo: apesar de os professores concordarem com a importância da prática escrita para a aprendizagem dos saberes acadêmicos em geral, há pouco ensino sistemático de produção escrita nas graduações. $(\text { CASTELLÓ et al, 2012, p. 574) })^{10}$

Algumas informações sobre iniciativas americanas em relação a ensino de escrita acadêmica aparecem em Gannett, Brereton, Donahue e Deane (2011), em artigo que aborda formas de encorajar a pesquisa feita por professores dos Estados Unidos e no Reino Unido nos campos de teoria e pedagogia da redação, retórica, literacias acadêmicas e estudos de escrita, apresentando alguns projetos que se dedicam a esses temas, dentre eles o 'Dartmouth Institute for Writing and Rhetoric, USA', dirigido pela professora associada Christiane Donahue, também organizadora da obra citada no parágrafo anterior. Esse instituto é uma unidade autônoma que coordena cursos de escrita introdutórios exigidos de todos os estudantes da Universidade de Dartmouth (Dartmouth College), cursos disciplinares de escrita de nível superior, cursos de oratória e de desenvolvimento do corpo docente. Os cursos iniciais têm por objetivo introduzir os calouros no mundo da pesquisa e orientá-los a escrever de forma mais adequada ao estilo acadêmico. ${ }^{11}$ (cf. GANNETT, BRERETON, DONAHUE, DEANE, 2011, p. 288)

\footnotetext{
${ }^{10}$ Até onde tivemos conhecimento, esse grupo de autores refere-se a práticas presenciais de aprendizagem, não fazendo referência a atividades realizadas em ambientes virtuais ou à combinação desses dois ambientes no ensino de produção escrita na universidade.

11 Tradução adaptada de: The Dartmouth Institute for Writing and Rhetoric, USA, is a stand-alone unit that coordinates introductory writing courses required of all Dartmouth students, upper-level disciplinary writing courses, speech courses, and faculty development. The writing courses include both US-style firstyear composition courses labeled 'first-year seminar' which introduce students to research (in the sense of reading the scholarship about a topic) and writing in a more discipline-related way, although they are not courses 'in the discipline.' GANNETT, BRERETON, DONAHUE, DEANE, 2011, p. 288)
} 
Esses trabalhos permitem constatar que o ensino de escrita acadêmica não é tema de estudos e pesquisas apenas no contexto nacional. Na verdade, sugerem que sistematizar tal ensino por meio da promoção de cursos e disciplinas que abordem a produção de texto acadêmico oferecidas aos calouros, como já ocorre em instituições como o "Dartmouth College", poderia ser bastante adequado também à cena universitária brasileira.

Nesse âmbito, examinamos ações que já ocorrem em duas das principais universidades públicas brasileiras em relação ao ensino de produção de texto acadêmico, além de registradas outras iniciativas particulares, o que certamente não chegará perto de esgotar a totalidade do que acontece no conjunto examinado, mas permite ilustrar a crescente preocupação das instituições e de profissionais de ensino de redação de textos acadêmicos em ocupar uma lacuna que se constitui entre a necessidade de comunicar o saber científico e o desenvolvimento de competências específicas exigidas na produção escrita dos gêneros acadêmicos.

1.2. Algumas iniciativas em universidades pesquisadas

Tendo em vista a dimensão dos cursos superiores observados no sudeste de nosso país, observamos que há poucos programas regulares de ensino de escrita acadêmica, como se verá a seguir, fazendo parte do currículo dos cursos. Por outro lado, já existem algumas iniciativas de promover cursos de extensão e workshops, com o objetivo principal de auxiliar alunos, em especial os de pós-graduação, a produzirem suas dissertações e teses. Informações obtidas pessoalmente - em encontros com outros profissionais ocorridos, na maioria das vezes, durante a participação em eventos da área - ou por meio de consultas via internet, confirmam o interesse de universidades públicas e particulares, ou de profissionais ligados a elas, em organizar cursos sobre redação acadêmica, como está relatado a seguir.

No caso da USP, Universidade de São Paulo, há várias iniciativas de promover o ensino de escrita acadêmica, das quais destacamos três que acontecem na Faculdade de Filosofia, Letras e Ciências Humanas, a FFLCH-USP. Regularmente, a cada semestre, acontecem os cursos 'Redação Acadêmica para Graduação' e 'Redação Acadêmica para PósGraduação', oferecidos pelo setor de Cursos de Extensão e Cultura do Centro Interdepartamental de Línguas da FFLCH, destinados, respectivamente a estudantes brasileiros e estrangeiros de graduação e pós-graduação da comunidade USP, com o objetivo 
de "Orientar os participantes na edição do próprio texto, alertando-os para os principais problemas de redação nos trabalhos acadêmicos.", conforme informação disponível no link < http://clinguas.fflch.usp.br/node/1270>, acesso em 19/01/2016.

Também na FFLCH-USP, começou a ser ministrado no primeiro semestre de 2015 o curso 'Leitura e escrita de textos conceituais em humanidades. Práticas para a formação dos alunos de graduação e das licenciaturas da FFLCH', com o objetivo de "suprir deficiências de leitura e escrita de textos conceituais dos graduandos matriculados nos dois primeiros anos das áreas de conhecimento aglutinadas na FFLCH, com vistas a dar instrumentos de trabalho essenciais para a formação de professores e pesquisadores". Tais informações foram transmitidas a docentes e graduandos por meio da página oficial da FFLCH-USP na rede social Facebook em 01/09/2015 (acesso pelo link <https://www.facebook.com/FFLCH.USP> e pelo correio eletrônico interno da universidade como forma de anunciar a abertura de matrículas para o segundo semestre de 2015. Por termos presenciado o primeiro encontro dos participantes desse curso, tomamos conhecimento de que o número de inscritos foi muito superior às vagas abertas - mais de trezentas inscrições para as cinquenta vagas oferecidas - o que demonstra o interesse dos alunos pelo tema.

Há ainda um projeto denominado 'Laboratório de Letramento Acadêmico em Línguas Materna e Estrangeiras', criado em 2011 pelas Profas. Dras. Marília Mendes Ferreira e Eliane G. Lousada das áreas de inglês e francês do Departamento de Letras Modernas da Faculdade de Filosofia, Letras e Ciências Humanas da Universidade de São Paulo. Na aba ‘Serviços’ do site do projeto (disponível no link <http://letramentoacademico.fflch.usp.br/node/4> acesso em 19/01/2016), é informado que o Laboratório de Letramento Acadêmico oferece "workshops, palestras e atendimentos individuais gratuitos para auxiliar o aluno a dominar a escrita acadêmica", desenvolvendo suas habilidades de escrita em francês, inglês e português para que os usuários alcancem independência na produção de seus textos, tornando-se autônomos. Conforme o vídeo que pode ser acessado na aba 'Home' do referido site, o aluno pode agendar sessões em que trará seu texto e poderá discuti-lo com um monitor treinado pelos professores responsáveis pelo projeto.

Também é possível mencionar algumas iniciativas individuais de profissionais ligados à USP, como a do Prof. Dr. Valtencir Zucolotto, Professor Associado e coordenador do Laboratório de Nanomedicina e Nanotoxicologia do Instituto de Física de São Carlos - IFSCUSP, que ministra presencialmente e também veicula gratuitamente por meio do link <http://escritacientifica.com/pt-BR/> (Acesso em 19/01/2016), apostilas e videoaulas, cujo 
objetivo é a disseminação de conhecimentos e treinamento na área de Escrita Científica, para, segundo texto do próprio site: "qualificar cientistas, pesquisadores e alunos de pós-graduação para o processamento e produção de Artigos Científicos de Alto Impacto”. Os cursos são destinados às áreas de Exatas, Biomédicas, Engenharia, Administração, Economia e Contabilidade, abordando questões de Estrutura e Linguagem do Artigo científico referentes a essas áreas, mas, diferente da proposta deste estudo, só considera a escrita de artigos em língua inglesa, aconselhando inclusive os alunos a escreverem seus 'papers' diretamente em inglês e não em português, para depois traduzirem.

A Universidade Estadual de Campinas, UNICAMP, no catálogo de cursos de extensão oferecidos pelo Instituto de Estudos da Linguagem (IEL) do curso de Letras e ministrados com alguma regularidade, divulga títulos como 'Redação Científica', 'Redação Científica Módulo II' e 'Redação científica: ler e escrever', todos sob a responsabilidade da Professora Anna Christina Bentes da Silva e dedicados à elaboração dos gêneros da redação científica, abordando aspectos estruturais, linguísticos e estilísticos.

Recentemente, em 10/06/2014, o site da Agência FAPESP, <agencia.fapesp.br>, divulgou nota sobre o lançamento de um serviço gratuito via internet para tirar dúvidas relacionadas à redação científica de estudantes, professores de graduação e pós-graduação e pesquisadores. Trata-se do site <http://www.gilsonvolpato.com.br> (acesso em 19/01/2016) do 'Clube SOS Ciência', coordenado pelo Prof. Dr. Gilson Luiz Volpato, do Departamento de Fisiologia do Instituto de Biociências da Universidade Estadual Paulista (UNESP), campus Botucatu, autor também de vários livros sobre Redação Científica. Os usuários cadastrados podem tirar dúvidas sobre alguns temas como Educação, Ética, Metodologia, mas principalmente sobre Redação científica, enviando perguntas que são respondidas pelos responsáveis, em geral pelo próprio Prof. Volpato, assistir a palestras proferidas regularmente por esse pesquisador e ainda participar de cursos online sobre Redação Científica.

Debates ocorridos entre os professores universitários brasileiros participantes do curso 'Como lidar com a escrita científica na universidade', ministrado pela Profa. Dra. Maria da Graça L. Castro Pinto, da Universidade do Porto, Portugal, durante o InPLA-SIL $2013^{12}$, sugeriram que o desenvolvimento de práticas de ensino de texto acadêmico de forma regular ainda não ocorria nas instituições em que os participantes trabalhavam (UNICAMP,

\footnotetext{
12 O InPLA-SIL 2013, combinação do $19^{\circ}$ Intercâmbio de Pesquisa em Linguística Aplicada e do $5^{\circ}$. Seminário Internacional de Linguística, aconteceu em outubro de 2013 na Universidade Cruzeiro do Sul, São Paulo-SP.
} 
UNIUBE, UEL, UFV, FATEC Jahu) mas que seus docentes já buscavam subsídios para implantar tais programas.

Além dessa observação empírica, que parece apontar para uma crescente valorização do ensino de produção escrita acadêmica, para conhecer a posição de uma amostra de professores universitários a respeito do ensino de texto acadêmico e da utilização de ambientes presenciais e virtuais de aprendizagem, temas de interesse para este estudo, um questionário sobre o tema foi elaborado e aplicado via ambiente virtual. O detalhamento sobre a metodologia utilizada e os resultados obtidos são apresentados a seguir.

1.3 Como se trata o ensino de escrita acadêmica em algumas universidades brasileiras

\subsubsection{Metodologia e questões propostas a professores}

Ao refletir sobre aspectos metodológicos quantitativos e qualitativos no que se refere às pesquisas que têm como alvo as situações, instituições e práticas educacionais, Thiollent (1984, p. 46), afirma que:

(...) a partir da visão de conjunto da temática da metodologia, existe um leque de preocupações muito diversificadas que não podemos resumir numa oposição quantitativo versus qualitativo. A metodologia não consiste num pequeno número de regras. É um amplo conjunto de conhecimentos com o qual o pesquisador procura encontrar subsídios para nortear suas pesquisas. As escolhas são efetuadas em função dos objetivos das pesquisas e das características das instituições.

Esse estudioso das metodologias na pesquisa em educação distingue vários enfoques, ora privilegiando aspectos qualitativos, ora quantitativos, que podem ser combinados e articulados numa visão maior, evitando radicalismos. Segundo Thiollent, qualquer fato educativo pode ser descrito tanto em termos de tamanho da população, repartição das categorias (aspectos quantitativos), como em significação e compreensão (aspectos qualitativos). Ele lembra ainda que investigar, obter e descrever resultados consiste em elaborar um discurso sobre determinado assunto, já que "os fatos ou o real não falam sozinhos". (1984, p. 47)

Esse autor defende que, dentro de uma concepção do conhecimento que seja também ação, os objetivos de uma pesquisa, em especial na área da educação, não devem ser apenas descrever ou avaliar resultados, mas também utilizar o conhecimento obtido para transformar a situação, interferindo nas práticas educacionais. Estamos, na elaboração deste trabalho, 
fortemente alinhados a esse pensamento, por acreditarmos que, em termos de fazer pedagógico, o ciclo Construção>Desconstrução>Reconstrução repete-se continuamente, conforme for o resultado obtido a cada pesquisa ou curso, seja sob o ponto de vista do professor, seja sob a ótica dos alunos, cuja posição também deve ser consultada.

Na pesquisa realizada para o presente estudo, para conhecer o que pensa um grupo de professores do ensino superior sobre a situação do ensino de escrita acadêmica nas universidades em que trabalham, com o intuito de propor uma prática educativa que se adequasse à situação observada, optou-se por utilizar questionário do tipo 'Formulário Google', elaborado em ambiente virtual com vinte (20) questões fechadas e abertas para conhecer as características e posições dos respondentes.

Além da facilidade e da rapidez de contato que esses meios proporcionam, a utilização dessa ferramenta Google possibilita elaborar qualquer quantidade de perguntas, definir o tipo de resposta desejado - textos menores, parágrafos, múltipla escolha com opção 'Outro' - e enviar o questionário ou apenas o link diretamente ao email ou à página da rede social do participante, para que seja acessado e respondido. Outra vantagem da aplicação online do questionário é que, a partir do recebimento do convite com o link, a participação do entrevistado pode acontecer a qualquer momento, conforme sua disponibilidade, o que tende a contribuir para que produza suas respostas de modo mais satisfatório, sem pressa.

Ao final de sua participação, o respondente aciona o 'botão' 'Enviar formulário', e manda as informações ao pesquisador. As respostas vão sendo armazenadas organizadamente no Google Drive e podem ser acessadas nesse ambiente pelo pesquisador. É possível também fazer download de cópias de segurança das respostas recebidas em diversos formatos de documentos, como a planilha Microsoft Excel (.xlsx) ou o documento PDF (.pdf), e arquiválas para visualização e a consulta das informações, sem que seja necessário usar o ambiente digital. As cópias originais dos documentos arquivados não constam desse estudo por motivos éticos, mas as informações obtidas podem ser consultadas na seção de ANEXOS (p. 202).

A definição do perfil de professores convidados a responderem à pesquisa levou em conta sua vinculação institucional e - por meio de pesquisa aos respectivos currículos e indicações de outros professores especialistas na área - sua atuação e interesse na área de ensino de produção textual em geral, ou especificamente de gêneros acadêmicos. Observou-se ainda se os projetos dos quais esses profissionais participavam e sua produção acadêmica publicada em livros e revistas científicas vinculavam-se ao contexto da escrita acadêmica, mesmo que o docente não estivesse atuando em cursos de Letras. O ANEXO F, da seção de 
ANEXOS, corresponde a um modelo de email enviado a cento e um (101) professores com o convite a participarem da pesquisa.

Cumpre registrar que houve algumas dificuldades em se encontrarem professores que ministrassem disciplinas específicas sobre escrita acadêmica de modo sistematizado, como requeria o perfil dos docentes pesquisados. As respostas recebidas, entretanto, de dez (10) profissionais do ensino de Língua Portuguesa de universidades como USP-SP, UNICAMP, UERJ, UFRJ, UFU, FMU-SP, PUC-PR constituem material extremamente significativo para as análises que este trabalho quer realizar, por conta de ter atingido um público bastante específico e revelar o pensamento e o tratamento didático que esse grupo dá à escrita acadêmica em suas instituições.

Quanto às questões propostas, constam algumas que cumprem a função de identificação, porém, como foi garantido o anonimato a todos os respondentes, as informações que podem identificá-los pessoalmente - como 'Nome', 'Email' ou 'Sexo' (Questões 1, 2 e 3) - não estão divulgadas. Entretanto, algumas informações que podem ajudar na caracterização do grupo, como 'Grupo etário a que pertence' (Questão 4), foram consideradas e apresentadas em forma de gráficos. Atribuiu-se a cada pesquisado uma sigla e um número, não apenas por conta do anonimato, mas também para garantir que cada conjunto de informações tenha sido fornecido pelo mesmo indivíduo. Assim, teremos RP1, RP2, RP3..., respectivamente a cada Respondente Professor. Para facilitar a consulta, a totalidade das respostas obtidas encontra-se transcrita na seção ANEXOS deste trabalho, no ANEXO H.

Para contribuir com a caracterização dos Respondentes Professores (RPs), há questões sobre a 'Universidade/s em que leciona' (Questão 5), o 'Nome do/s curso/s em que leciona' (Questão 6), o 'Nome da/s disciplina/s que ministra' (Questão 7) e o 'Tempo de experiência como professor universitário’ (Questão 8). Perguntou-se também aos professores se suas aulas são presenciais ou virtuais (Questão 9) e qual é a metodologia utilizada para ministrar as disciplinas que leciona (Questão 10); se o ensino de produção de texto acadêmico ou de artigo científico é um dos objetivos dessas disciplinas (Questão 11) e, em caso de resposta positiva, há quanto tempo o professor já lecionava disciplina/s com esse objetivo (Questão 12). Com o propósito de conhecer a opinião dos RPs, perguntou-se ainda se eles consideram que a prática de ensinar a produzir texto acadêmico promove a aprendizagem em geral, pedindo-lhes que justificassem sua posição. (Questão 13)

Em relação à investigação sobre o uso, no ensino de produção de texto acadêmico, de práticas combinadas realizadas em ambientes presencial e virtual, indagou-se aos 
Respondentes Professores se eles utilizam meios digitais para se comunicar com seus alunos como forma complementar de apoio às aulas presenciais (Questão 14) e, em caso de resposta positiva, pediu-se que eles indicassem por quais meios é feita essa comunicação (Emails, Grupos Google, Facebook, Ambientes Virtuais de Aprendizagem, etc.) (Questão 15), e se eles mesmos a realizam ou se recebem ajuda de um monitor (Questão 16). Pediu-se também para enumerarem as atividades realizadas por meio dessa comunicação virtual (Questão 17).

Com relação à participação dos alunos através desses meios, sob a ótica do professor, foi perguntado se o RP enfrenta algum tipo de problema por conta da utilização dos ambientes virtuais (Questão 18) e como era o envolvimento de seus alunos nesse processo (Questão 19). Por fim, os Respondentes Professores opinaram sobre a importância ou não do uso do 'canal virtual' como forma de apoio ao ensino de produção de texto acadêmico, justificando sua colocação (Questão 20).

Para maior esclarecimento, seguem as questões propostas, exemplificando-se as modalidades que pediam respostas abertas ou com múltiplas alternativas:

1. Nome (Resposta aberta)

2. Email (Resposta aberta)

3. Sexo (Alternativas: Feminino / Masculino)

4. Grupo etário a que pertence (Alternativas: 20 a 29 anos / 30 a 39 anos / 40 a 49 anos / 50 a 59 anos / 60 anos ou mais)

5. Universidade/s em que leciona (Resposta aberta)

6. Nome do/s curso/s em que leciona (Resposta aberta)

7. Nome da/s disciplina/s que ministra (Resposta aberta)

8. Tempo de experiência como professor universitário. (Alternativas: Menos de 1 ano / 1 a $3 \operatorname{anos} / 4$ a $6 \operatorname{anos} / 7$ a $10 \operatorname{anos} / 11$ a $15 \operatorname{anos} / 16$ a 20 anos / Mais de 20 anos)

9. Suas aulas são: (Alternativas: Presenciais / A distância / Parte presenciais, parte a distância / Presenciais, mas utiliza meios digitais para se comunicar com os alunos fora do horário de aula)

10. Que metodologia você utiliza para ministrar a/s disciplina/s que leciona? É possível escolher várias alternativas. (Alternativas: Aulas expositivas / Questionários / Leitura de 
textos teóricos / Seminários em grupo / Seminários individuais / Produção de textos / Reescrita de textos após revisão / Outro: Resposta aberta)

11. O ensino de produção de texto acadêmico ou de artigo científico é um dos objetivos da disciplina que você leciona? (Alternativas: Sim / Não)

12. Em caso de resposta positiva à pergunta anterior, há quanto tempo você já leciona disciplina/s que tem/têm esse objetivo? (Resposta aberta)

13. Se você respondeu que ensinar a produzir texto acadêmico é um dos objetivos de sua disciplina, você considera que essa prática promove a aprendizagem em geral? Por quê? (Resposta aberta)

14. Você utiliza meios digitais para se comunicar com seus alunos como forma complementar de apoio às aulas presenciais? (Alternativas: Sim / Não)

15. Em caso de resposta positiva à questão anterior, como se dá essa comunicação? (Alternativas: Formação de um grupo de emails e utilização do correio eletrônico convencional / Criação de um grupo no Google / Abertura de uma página no Facebook / Utilização de ambientes educacionais do tipo plataforma Moodle / Outro: Resposta aberta)

16. Quem cuida desse grupo? Você mesmo ou um monitor? (Resposta aberta)

17. Que atividades você realiza por meio dessa comunicação virtual? Indique, por favor, todas as alternativas que se aplicam. (Alternativas: Posta textos teóricos / Envia avisos sobre calendário e programa da disciplina / Recebe e manda mensagens a alunos individualmente sobre temas da disciplina / Recebe e manda mensagens a alunos individualmente sobre temas que não se referem à disciplina / Propõe tarefas / Recebe tarefas / Orienta a produção de tarefas / Revisa e comenta tarefas / Realiza questionários / Propõe e gerencia fóruns de discussão / Outro: Resposta aberta)

18. Você enfrenta algum tipo de problema por conta da utilização desses ambientes virtuais? Em caso positivo, quais? (Resposta aberta)

19. E no que diz respeito aos alunos, como se dá o envolvimento deles com o ambiente virtual? Indique, por favor, todas as alternativas que se aplicam. (Alternativas: Aceitam prontamente / Reclamam / Não reclamam / Participam ativamente / Participam pouco / Não participam / Têm dificuldades em acessar os meios digitais / Aprendem rapidamente a acessar e utilizar as ferramentas digitais / Outro: Resposta aberta) 
20. Que importância você atribui ao uso desse 'canal virtual' como forma de apoio ao ensino de produção de texto acadêmico? Por quê? (Resposta aberta)

Pode-se dizer que o questionário enviado aos professores articula aspectos quantitativos e qualitativos - por conter dez (10) perguntas 'fechadas' (números três, quatro, oito, nove, dez, onze, catorze, quinze, dezessete, dezenove), que propõem respostas prontas de múltipla escolha; e dez (10) perguntas 'abertas' (números: um, dois, cinco, seis, sete, doze, treze, dezesseis, dezoito, vinte), que permitem ao participante produzir as próprias respostas embora não proporcione envolvimento maior entre pesquisador e pesquisados para que estes desenvolvam mais suas respostas. Apesar de haver várias questões fechadas, portanto com características quantitativas, no questionário proposto aos professores, optou-se por uma análise qualitativa das respostas, sem a extrapolação de dados para uma população maior, visto ser baixa a base da pesquisa, isto é, não ser tão grande o número de participantes.

São apresentados, no item 1.3.2 a seguir, alguns gráficos que representam resultados obtidos, a respectiva análise, e também a análise de respostas a questões abertas.

1.3.2 Tabulação de resultados: gráficos e análises de questões abertas e fechadas

Para melhor visualização dos resultados obtidos pela pesquisa, alguns gráficos foram elaborados a partir das questões fechadas com respostas escolhidas entre as alternativas apresentadas. Os resultados obtidos são analisados em seguida a cada gráfico. Seguindo a ordem das perguntas no questionário, há também análises referentes às respostas a questões abertas, aquelas que permitem a expressão de opinião por meio da produção de palavras, pequenos textos ou parágrafos. Conforme dissemos, a transcrição da totalidade das respostas aqui analisadas pode ser consultada no ANEXO H da seção de ANEXOS deste estudo.

Como mencionamos anteriormente, as respostas dadas às questões de identificação (Questão 1: Nome, Questão 2: Email, Questão 3: Sexo) não serão referidas por conta da garantia de sigilo aos participantes, portanto iniciaremos as análises dos gráficos, quando for possível uma representação gráfica, e das respostas às questões abertas a partir da Questão 4. 


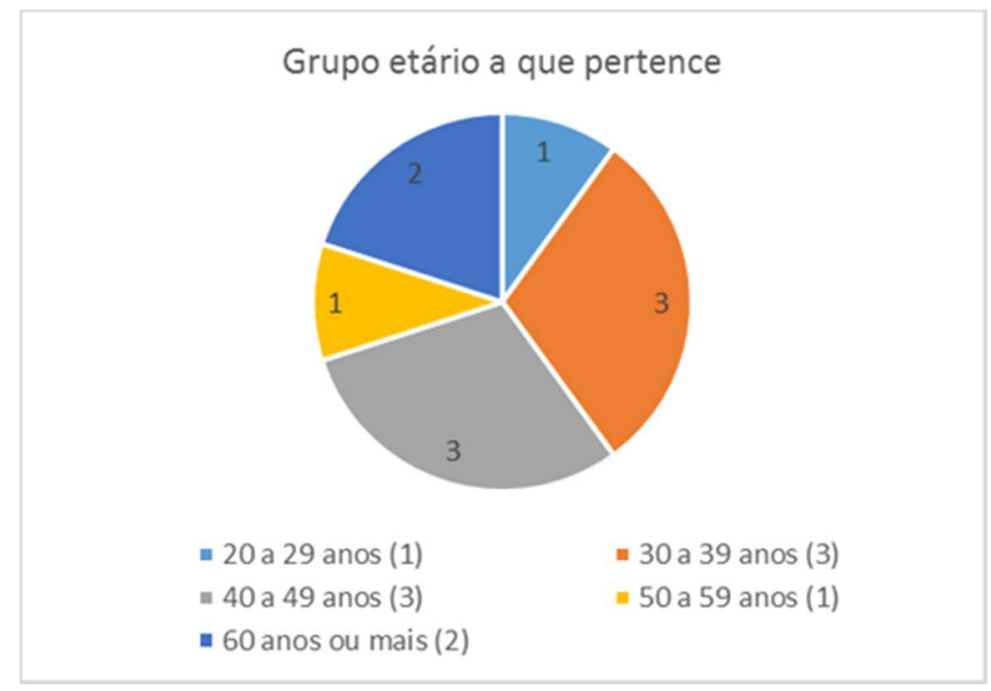

Gráfico 1 - Questão 4: Grupo etário a que pertence

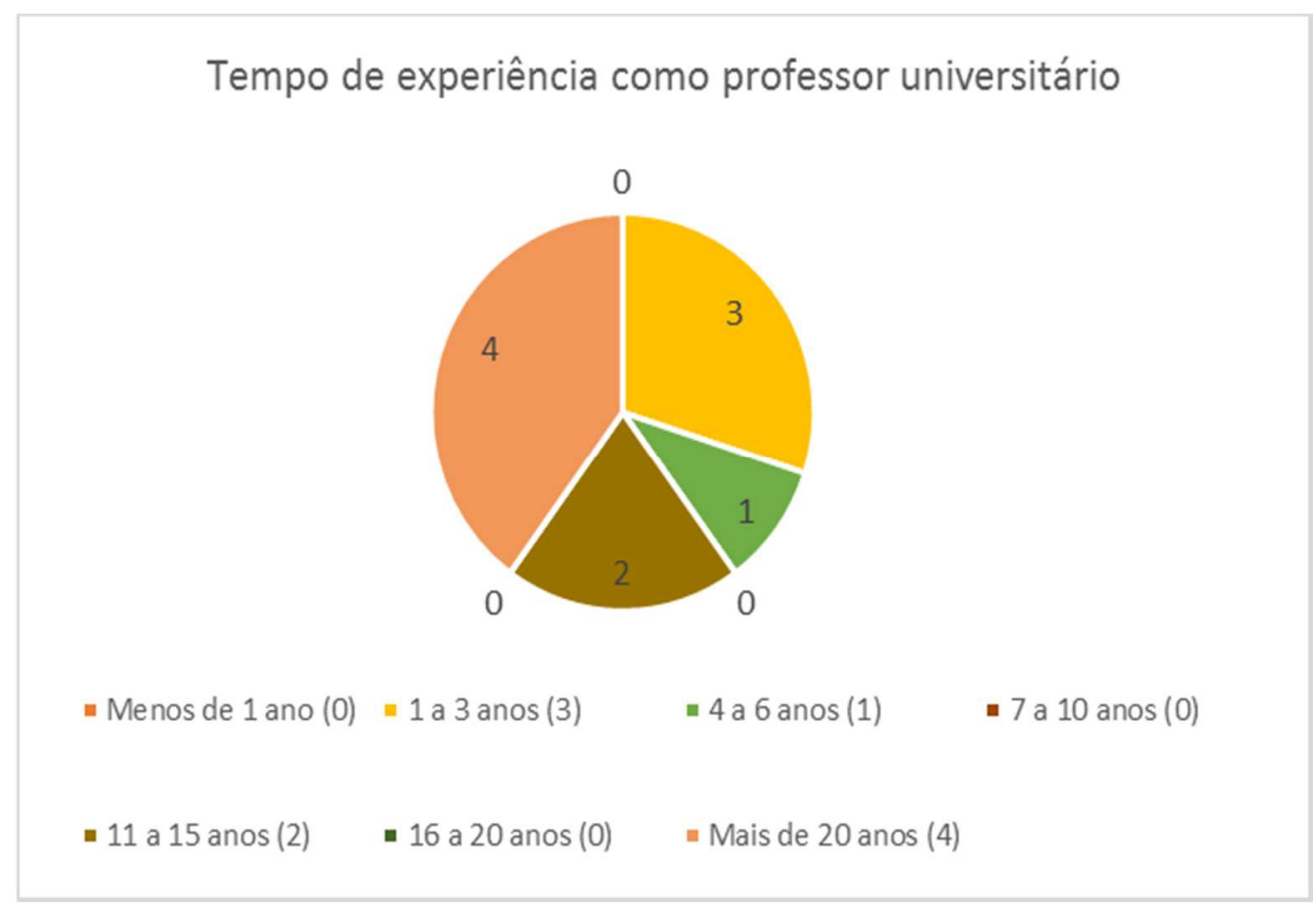

Gráfico 2 - Questão 8: Tempo de experiência como professor universitário

Ao observarem-se os gráficos correspondentes a grupo etário (Questão 4) e tempo de experiência (Questão 8), pode-se perceber que há participantes em praticamente todos os grupos, com tempo de experiência como professor universitário também variável, mas sempre maior que 1 ano e, em 40\% dos casos, com mais de vinte (20) anos de experiência. Nesse 
sentido, pode-se dizer que os Respondentes Professores (RPs) formam um conjunto em que há diversidade de faixa etária e tempo de experiência, aspecto que consideramos positivo, pois vários grupos estão representados e as informações obtidas não refletem apenas opiniões de uma faixa etária ou de profissionais com pouca ou muita experiência profissional.

Como resposta a uma questão aberta sobre a Universidade em que os RPs lecionam (Questão 5), obteve-se como resposta: Universidade de São Paulo - USP, Universidade Estadual de Campinas - UNICAMP, Universidade Federal do Rio de Janeiro - UFRJ, Universidade Federal de Uberlândia - UFU, Universidade do Estado do Rio de Janeiro UERJ, Faculdades Metropolitanas Unidas - FMU, Universidade Candido Mendes - UCAM, Pontifícia Universidade Católica do Paraná - PUC-PR e União das Instituições Educacionais do Estado de São Paulo - UNIESP. Estão, portanto, representadas em nossa pesquisa algumas das principais instituições de ensino superior público do país entre outras do setor privado.

Ao nomear os cursos em que lecionam em outra questão aberta (Questão 6), também é possível verificar que há bastante variação. A maioria atua em cursos de graduação e pósgraduação de Letras, mas são mencionados também Estatística, Secretariado, Curso de Extensão de Redação Científica, Licenciatura em Química, Licenciatura em Física e Engenharia da Computação.

Respondendo à Questão 7, também aberta, os professores nomeiam as disciplinas que lecionam, todas ligadas ao ensino de Língua Portuguesa em suas diversas perspectivas, sempre de alguma forma relacionadas à leitura e produção textual, o que comprova sua adequação ao perfil desejado, de profissional que experimenta concretamente a situação de sala de aula e, portanto, pode opinar de maneira mais adequada sobre as práticas pedagógicas que ali acontecem.

Quando perguntados sobre a modalidade de suas aulas, como se pode ver no gráfico da Questão 9, a seguir, consideramos significativo que mais da metade dos participantes (sessenta por cento) tenha declarado dar aulas presenciais, mas utilizar meios digitais para se comunicar com os alunos, num indício de que já combinam as modalidades presenciais e a distância em sua prática de ensino, mesmo que apenas com finalidade comunicativa. 


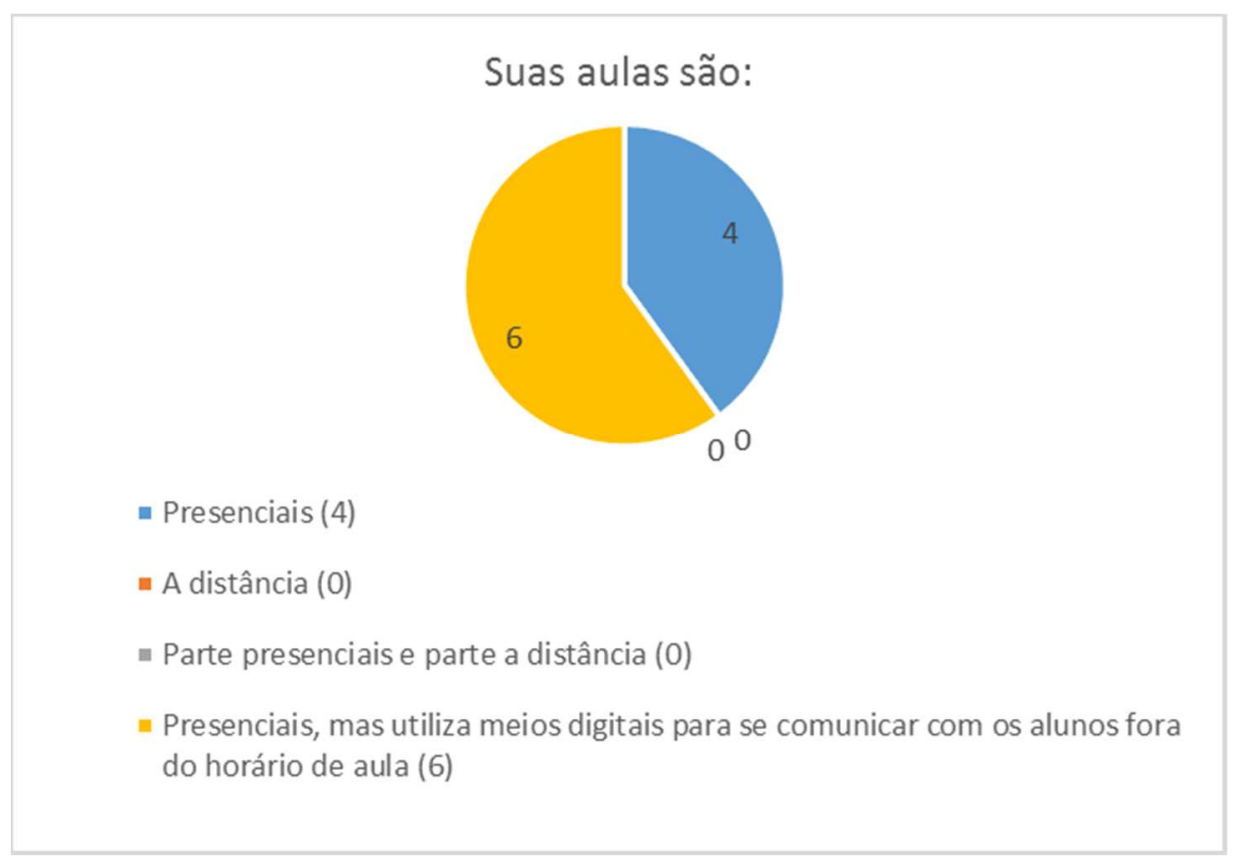

Gráfico 3 - Questão 9: Suas aulas são:

$\mathrm{Na}$ representação gráfica das respostas sobre metodologia utilizada para ministrar as aulas (Questão 10, a seguir) - uma pergunta em que os respondentes poderiam escolher uma ou mais entre várias alternativas possíveis - aparecem 'Aulas expositivas’ (90\%), Produção de textos (90\%), 'Reescrita de textos após revisão' (80\%), 'Leitura de textos teóricos' (70\%) e 'Seminários em grupo' (70\%), entre outras alternativas. Apenas um professor (10\%) apontou, preenchendo a alternativa 'Outros', a 'Análise linguística e revisão de texto', porém, como havia alternativa que indicava 'Reescrita após revisão' (80\%), é possível dizer que a revisão textual seja uma prática adotada pela maioria dos docentes pesquisados. 
Que metodologia você utiliza para ministrar a/s disciplina/s que leciona?
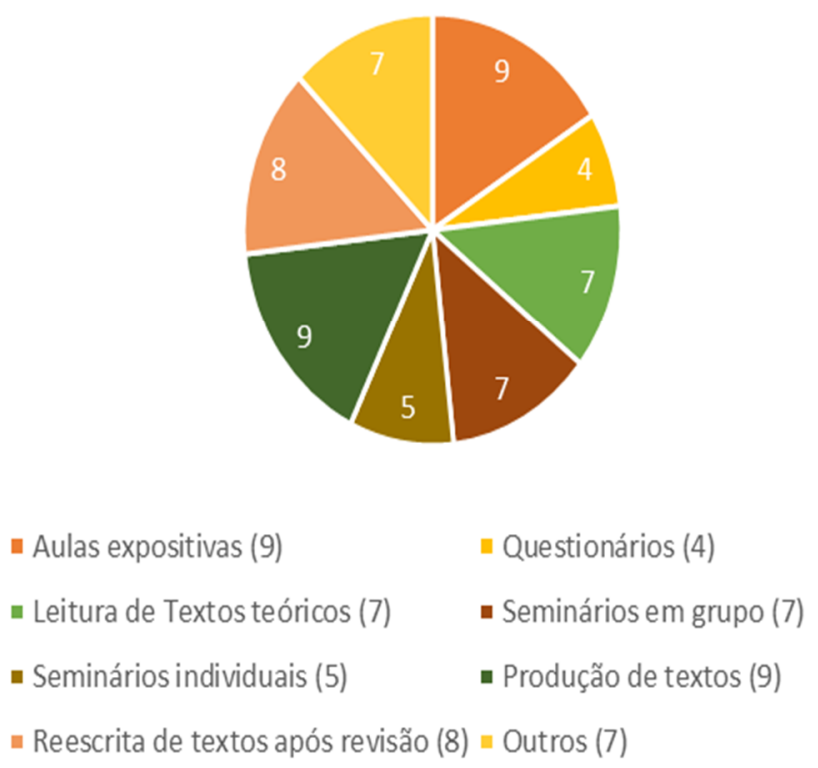

\section{Gráfico 4 - Questão 10: Que metodologia você utiliza para ministrar a/s disciplina/s que leciona? É possível escolher várias alternativas.}

Obs.1: Esse gráfico levou em conta todas as alternativas apontadas pelos professores, portanto representa quantos professores escolheram cada alternativa. A opção 'Outro' aparece relacionada à parte.

Obs.2: Foram relacionadas como outras opções metodológicas: Análise de textos (1), exercício de paráfrase (1), atividades orais - debates (1), Trabalho com músicas, filmes e quadros (1), Produção de materiais didáticos (1), Aulas lúdicas (1), Análise linguística e revisão de texto (1).

Chama ainda a atenção a opção da 'Reescrita' (escolhida por $80 \%$ dos professores), uma atividade considerada, na prática proposta por este estudo, de extrema importância na identificação de dificuldades apresentadas pelos alunos, no planejamento de atividades que abordem e objetivem ultrapassar tais dificuldades e na consequente construção do conhecimento sobre o gênero estudado. Essa linha de pensamento está em concordância com Dolz, Gagnon e Decândio (2010) quando esses autores abordam a questão dos 'rascunhos sucessivos'. Eles dizem:

O trabalho com os rascunhos sucessivos nos parece de grande importância e de imenso interesse. "Escrever é reescrever", dizia Roland Barthes; assim, o ensino da escrita exige que se leve em conta as produções escritas intermediárias, sendo que a identificação dos erros para melhorar o texto e a 
reescrita de trechos particulares são os dois principais procedimentos de auto-avaliação (sic.). (p. 62)

Dando sequência à análise, com respeito especificamente ao ensino de produção de texto acadêmico ou de artigo científico fazer parte dos objetivos das disciplinas que os pesquisados lecionam (Questão 11, a seguir), o gráfico mostra que 80\% deles respondem afirmativamente.

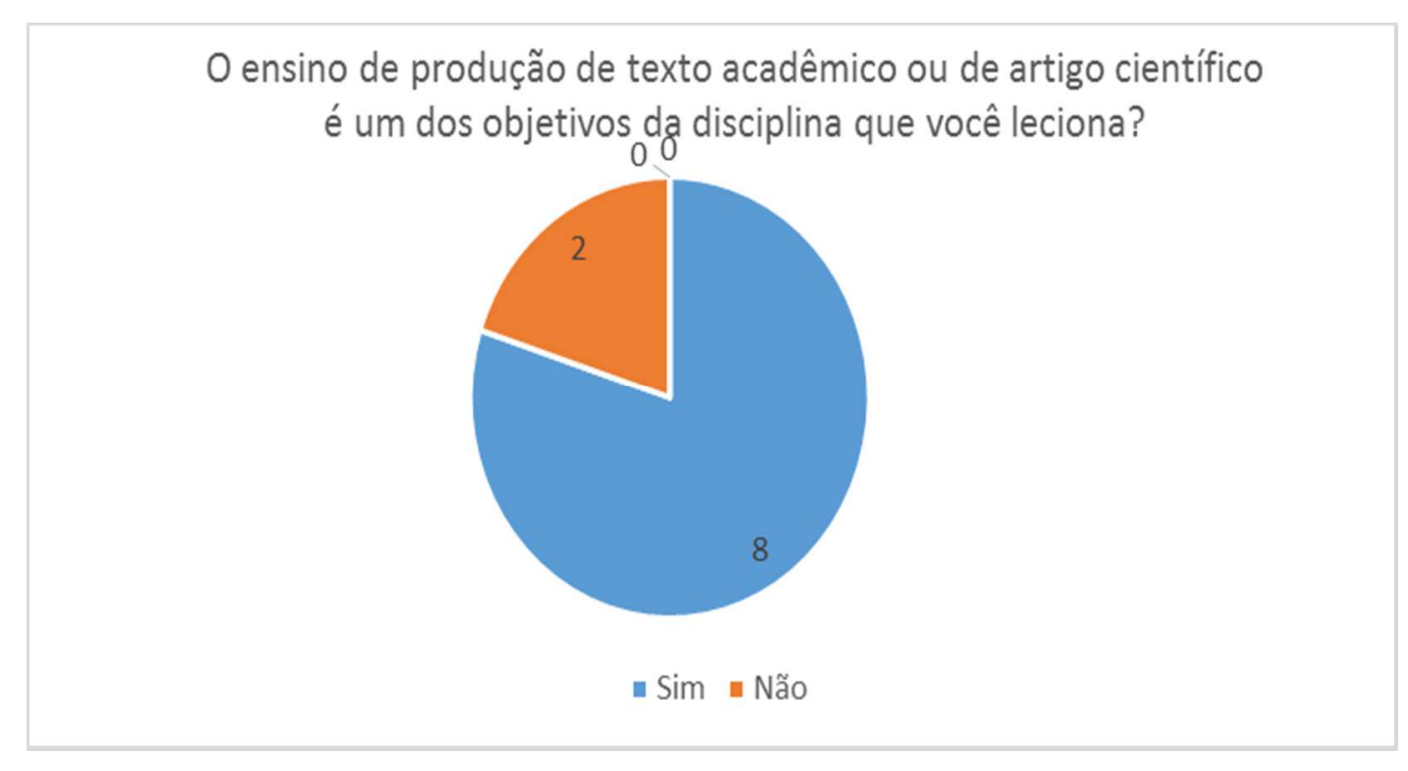

\section{Gráfico 5 - Questão 11: O ensino de produção de texto acadêmico ou de artigo científico é um dos objetivos da disciplina que você leciona?}

As Questões 12 e 13, de resposta aberta, complementam a questão anterior, e se destinam àqueles que responderam a ela afirmativamente. Na questão 12, pergunta-se há quantos anos os questionados já ensinam produção de texto acadêmico, com respostas variadas que vão de 1 (um) a 20 (vinte) anos. Na Questão 13, uma questão com resposta aberta por escrito, perguntados se consideram que a prática de ensinar escrita acadêmica promove a aprendizagem em geral, entre aqueles que ensinam escrita acadêmica todos responderam que 'Sim'.

Considerou-se significativo para o contexto deste estudo transcrever as justificativas, apresentadas a seguir, pois o conhecimento da posição dos participantes colaborou para se ter 
uma visão de seus objetivos e expectativas quanto ao ensino de produção de texto acadêmico atualmente no Brasil. São elas:

RP1 Sim, em razão de tanto colaborar para o ensino de língua quanto promover discussão e reflexão sobre determinados temas, específicos da área do curso.

RP2 Sim, porque, com as técnicas e correções dos textos dos alunos, consigo ver melhorias consideráveis, em especial em relação à seleção de informação e coesão referencial.

RP3 Sim, leva o aluno a ter uma atitude crítica perante o conhecimento. O agravante é que o aluno não vem preparado do Ensino Médio para esse gênero de texto, que exige compreensão de textos teóricos, da nomenclatura específica e sua aplicação a um "objeto de estudo", além disso, há a preparação para uma leitura crítica dos arcabouços teóricos.

RP4 Pela minha opção em relacionar a produção de linguagem oral e escrita ao desenvolvimento metalinguístico da pessoa, o que lhe proporciona, através do conhecimento sobre a linguagem como estrutura e como meio semiótico, uma maior autonomia nas diferentes práticas de letramento em que se engaja.

RP5 Sim, pois, de certa forma, auxilia os alunos, especialmente os calouros, a se planejarem ao lerem textos mais longos e exigidos durante o curso. Com fichamentos, resumos e resenhas, muitas vezes, não e necessário voltar ao teto original para estudar para a prova.

RP6 Sim. Aprender a escrever textos acadêmicos é entrar em contato com os princípios básicos da escrita em geral.

RP7 - (não respondeu)

RP8 - (não respondeu)

RP9 A produção do texto acadêmico, além do domínio da norma padrão da língua portuguesa, implica pesquisa prévia e reflexão. Assim sendo, a preparação para tal produção serve de base para que o aluno aprenda estudar.

RP10 Sim. As atividades de leitura e produção de textos acadêmicos, quando acompanhadas da análise linguística, da revisão e da reescrita de texto, promovem a aprendizagem, ou seja, o letramento acadêmico. Por meio desses procedimentos metodológicos, os alunos observam e compreendem as características textuais e discursivas dos gêneros que circulam no meio acadêmico, bem como percebem que esses elementos são fundamentais na construção do sentido dos diversos gêneros. Portanto, os alunos precisam apreender esses recursos para ler e produzir, com competência, os diversos gêneros, presentes no universo acadêmico, bem como transferir esses conhecimentos para prática profissional. 
A análise das respostas obtidas permite dizer que os professores concordam sobre a importância do ensino do texto acadêmico na universidade como forma de promoção da aprendizagem em geral, por entenderem que esta prática não só prepara o aluno para a escrita propriamente dita desse gênero, mas também o habilita à leitura crítica, à compreensão dos gêneros acadêmicos em geral - enquanto fundamentação teórica - e ainda à produção de diferentes gêneros - enquanto prática linguístico-discursiva -, pois tais habilidades podem ser transferidas para outros campos de atuação.

Em concordância com a posição dos professores pesquisados e mediante observações durante as aplicações da proposta de ensino que motivou este estudo, também acreditamos que o ensino de produção de texto acadêmico tem substancial importância para a aprendizagem dos saberes acadêmicos em geral, pois as habilidades linguísticas, reflexivas e críticas que o estudante adquire com essa prática didática podem ser transferidas a desempenhos em outras esferas. Essa posição vai ao encontro de uma de nossas hipóteses.

Além disso, a resposta de RP9 aponta na direção de que "a pesquisa prévia" que prepara para a produção escrita propriamente dita auxilia o aluno a 'aprender a estudar', uma afirmação que vem ao encontro de posições sobre operações cognitivas desenvolvidas durante a aplicação das práticas combinadas adotadas nesta pesquisa, conforme se trata no Capítulo 2 deste trabalho.

Analisando ainda os gráficos relativos à modalidade de ensino e uso de meios digitais (Questões 9, referida anteriormente e 14, a seguir), pode-se observar que os RPs consultados afirmam não ministrarem cursos a distância, apenas presenciais, embora $60 \%$ deles utilizem meios digitais para se comunicar com seus alunos fora do horário de aula (Questão 9). Entretanto, quando questionados mais diretamente sobre o uso de meios digitais como forma complementar de apoio às aulas presenciais (Questão 14), o 'Sim' foi unânime. Embora as respostas a essas duas questões pareçam contraditórias, pode-se dizer que de fato há utilização de meios virtuais para comunicação entre os professores pesquisados e seus alunos, já que, no gráfico referente à questão 15 , logo em seguida, as respostas indicam o uso de algumas modalidades possíveis de interação virtual. 


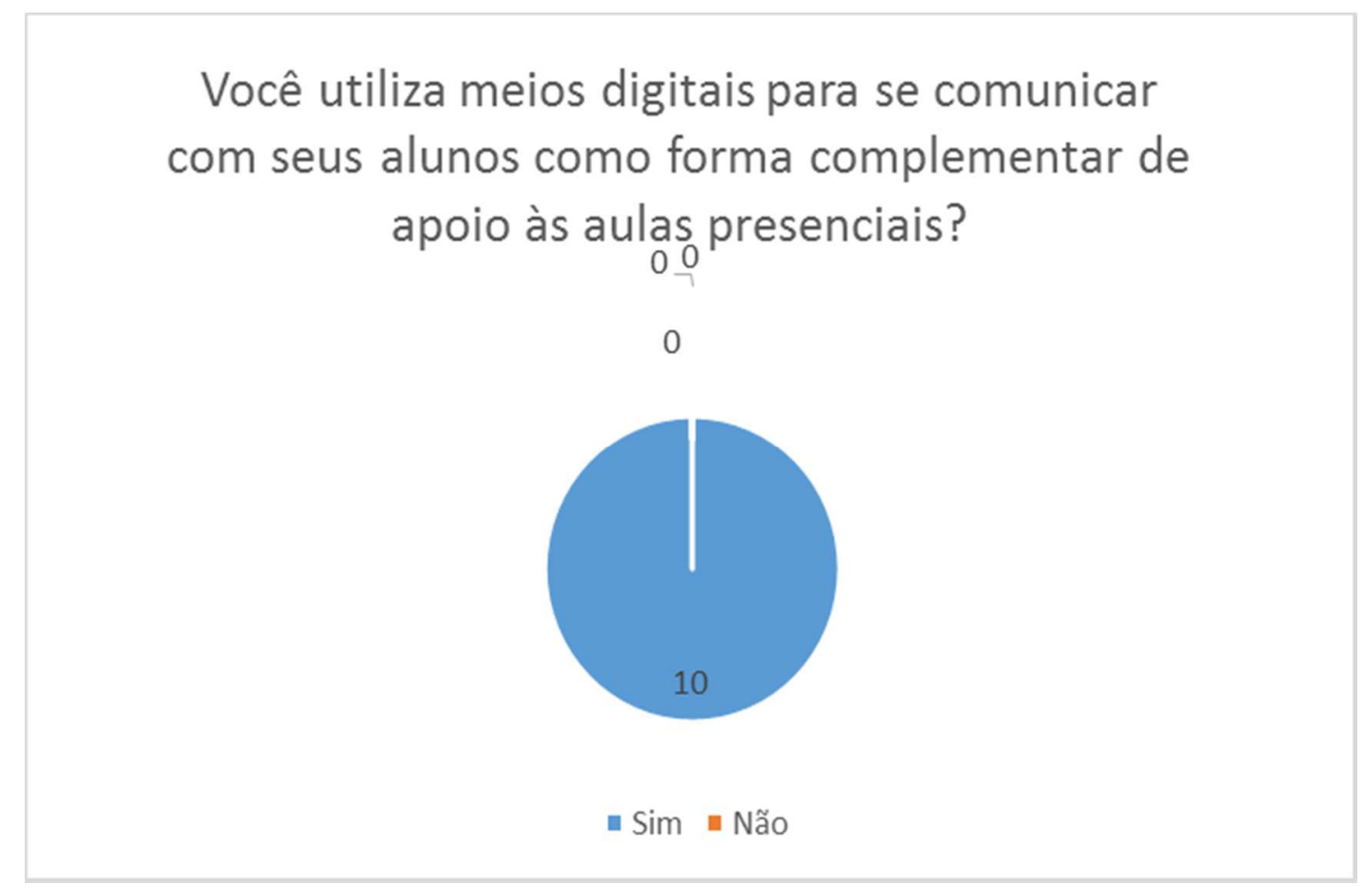

Gráfico 6 - Questão 14: Você utiliza meios digitais para se comunicar com seus alunos como forma complementar de apoio às aulas presenciais? 
Em caso de resposta positiva à questão anterior, como se dá essa comunicação?

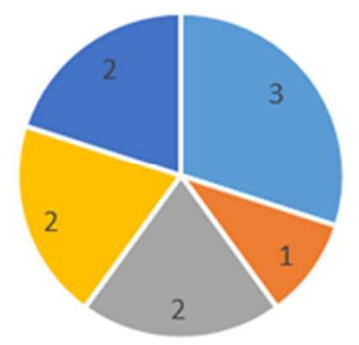

- Formação de um grupo de e-mails e utilização do correio eletrônico convencional (3)

- Criação de um grupo no Google (1)

- Abertura de uma página no Facebook (2)

= Utilização de ambientes educacionais do tipo plataforma Moodle (2)

- Outros (2)

Gráfico 7 - Questão 15: Em caso de resposta positiva à questão anterior, como se dá essa comunicação?

Obs.: Foram mencionadas na opção 'Outros": Apenas email (1) e Utilizo as três primeiras simultaneamente (1).

Sobre as atividades realizadas por meio da comunicação virtual (Questão 17, a seguir), uma pergunta que admitia optar por várias entre as alternativas propostas, o gráfico aponta que os itens mais escolhidos foram: Envio de avisos (100\%), Orientação para produção de tarefas (100\%), Postagem de textos teóricos (90\%), Recebimento de tarefas (90\%), Recebimento e envio de mensagens aos alunos (90\%), Revisão e comentários de tarefas (70\%). Tais resultados indicam que, para esses respondentes, o ambiente virtual, apesar de ainda ser muito usado como canal de comunicação com o objetivo de enviar mensagens, 
avisos e postar textos teóricos, também já consiste em instrumento didático por conta de seus objetivos de propor, orientar, receber, revisar e comentar tarefas.

Que atividades você realiza por meio dessa comunicação virtual? Indique, por favor, todas as alternativas que se aplicam.

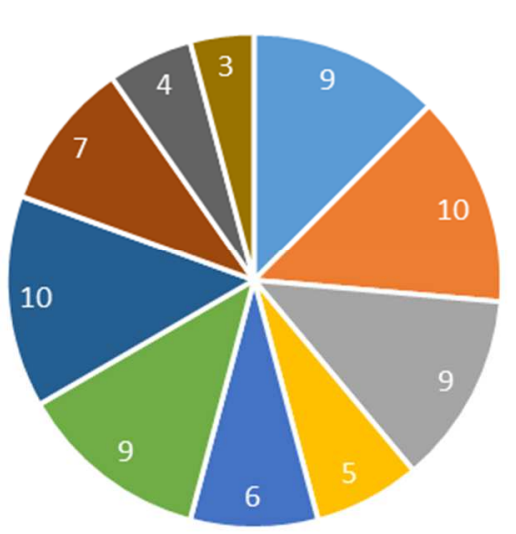

- Posta textos teóricos (9)

- Envia avisos sobre calendário e programa da disciplina (10)

- Recebe e manda mensagens a alunos individualmente sobre temas da disciplina (9)

- Recebe e manda mensagens a alunos individualmente sobre temas que não se referem à disciplina (5)

- Propõe tarefas (6)

- Recebe tarefas (9)

- Orienta a produção de tarefas (10)

- Revisa e comenta tarefas (7)

- Realiza questionários (4)

- Propõe e gerencia fóruns de discussão (3)

Gráfico 8 - Questão 17: Que atividades você realiza por meio dessa comunicação virtual? Indique, por favor, todas as alternativas que se aplicam.

Obs.: O gráfico da Questão 17 levou em conta todas as alternativas apontadas pelos professores, portanto representa quantos professores escolheram cada alternativa. A opção 'Outro' não foi escolhida. 
Na Questão 18, que permitia a elaboração de texto como resposta ao enfrentamento de problemas pelo uso dos ambientes virtuais, 40\% responderam 'Não'. Os que enfrentam problemas citam que há alunos que têm resistência ao contato digital, apresentando dificuldades de acesso às plataformas - foram citados o Teleduc e a Eureka da PUC-PR) - ou ainda aqueles que reclamam por ter tarefas virtuais. Na reprodução, a seguir, da resposta do participante RP10, pode-se observar um relato mais detalhado da relação que o próprio professor tem com a plataforma de aprendizagem que utiliza.

RP10 Apesar das inúmeras vantagens proporcionadas pelo Eureka (Sistema institucional da PUCPR), as atividades, organizadas pelo professor, precisam ser orientadas de forma detalhada a fim de que os alunos compreendam o que precisa ser feito e como deve ser feito. Por exemplo, caso a alunos não postem os trabalhos no local solicitado, o professor levará um tempo significativo para localizar esses trabalhos. Todos os roteiros que orientam a execução de atividades, realizadas a distância, precisam ser objetivos e claros e isso requer tempo e dedicação. O professor precisa reavaliar as orientações a fim de observar se elas estão adequadas e se atendem ao propósito comunicativo. Enfim, é preciso dispor de muito tempo para preparar as atividades e, muitas vezes, o professor não é remunerado de forma adequada.

Em sua declaração, o participante aborda questões consideradas muito significativas para esta e muitas das pesquisas sobre modalidades de ensino mediadas por computador, como o cuidado com o emprego de linguagem adequada aos ambientes virtuais de aprendizagem quando afirma que "Todos os roteiros que orientam a execução de atividades, realizadas a distância, precisam ser objetivos e claros" e que "as atividades, organizadas pelo professor, precisam ser orientadas de forma detalhada a fim de que os alunos compreendam o que precisa ser feito e como deve ser feito." Tais questões serão referidas no próximo capítulo, que tratará, entre outros temas, dos ambientes virtuais e o ensino por meio deles. Completando a declaração de RP10, há ainda a menção à necessidade de mais tempo disponível para o professor preparar as atividades a distância e à inadequação da remuneração recebida por este trabalho extra.

A representação gráfica das respostas à Questão 19, a seguir, expõe, sob a perspectiva do grupo de professores pesquisado, o envolvimento de seus alunos com o ambiente virtual. Estes últimos tendem, em sua maioria, a aceitar prontamente (90\%), participar ativamente $(60 \%)$ e aprender rapidamente a usar os ambientes virtuais (40\%), embora ainda haja quem participe pouco (30\%), tenha dificuldades $(20 \%)$ e reclame $(20 \%)$ em relação a essas atividades. Observando-se esses dados, parece possível dizer a percepção que os entrevistados 
têm é que seus alunos mais "aceitam e participam" do que "têm dificuldades ou pouca participação" nas atividades que acontecem em ambientes virtuais.

E no que diz respeito aos alunos, como se dá o envolvimento deles com o ambiente virtual? Indique, por favor, todas as alternativas que se aplicam.

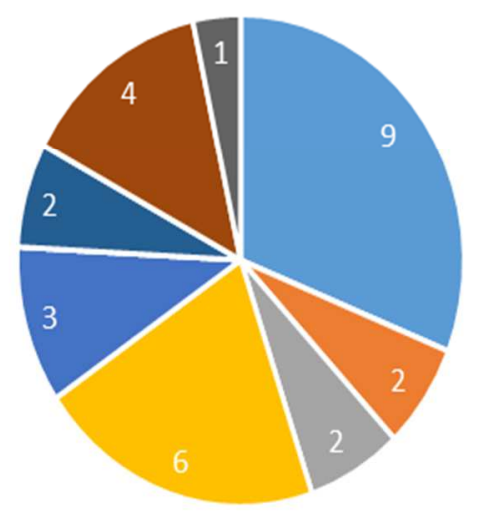

- Aceitam prontamente (9)

- Reclamam (2)

- Não reclamam (2)

- Participam ativamente (6)

- Participam pouco (3)

- Não participam (0)

- Têm dificuldade em acessar os meios digitais (2)

- Aprendem rapidamente a acessar e utilizar as ferramentas digitais (4)

- Outro (1)

Gráfico 9 - Questão 19: E no que diz respeito aos alunos, como se dá o envolvimento deles com o ambiente virtual? Indique, por favor, todas as alternativas que se aplicam.

Obs.1: Esse gráfico levou em conta todas as alternativas apontadas pelos professores, portanto representa quantos professores escolheram cada alternativa. A opção 'Outro' aparece relacionada à parte.

Obs. 2: Foi mencionada na opção "Outro": Alguns têm dificuldade em acessar os meios digitais (1). 
Completando o questionário, uma pergunta aberta (Questão 20) pede aos pesquisados que opinem sobre o uso do canal virtual como forma de apoio ao ensino presencial de escrita acadêmica e justifiquem sua posição. Segue a transcrição das respostas, pelo interesse que esta pesquisa tem em conhecer como acontece atualmente a combinação de atividades presenciais e virtuais no ensino de escrita acadêmica.

RP1 Quanto ao e-mail, ele torna mais rápido o diálogo entre professor e aluno, mas é uma ferramenta limitada. Não consigo resolver, via e-mail, todos os assuntos que são enviados. Muitos alunos procuram-me pessoalmente, principalmente, em casos de correção de trabalho.

RP2 Como não usamos material apostilado nem livro (apenas indicações de leitura extra), o canal virtual é a forma como distribuo os materiais didáticos do curso. Além disso, ele facilita o controle de postagem das tarefas dos alunos e a correção que faço dos textos. Se contasse apenas com envio e resposta por e-mail seria muito complicado para fazer o gerenciamento.

RP3 Estamos na era virtual e o aproveitamento desses recursos é cada vez mais uma realidade. Acho que tanto os professores quanto os alunos se beneficiam, quando há planejamento.

RP4 Oportunidade de manter contato constante, resolvendo questões gerais do curso e específicas de cada aluno sem a necessidade presencial, e de monitorar o interesse dos alunos nos aspectos da disciplina.

RP5 Como encontro meus alunos, em geral, uma ou duas vezes por semana, e, quase sempre, utilizo material de apoio nas aulas, preciso que os eles levem os textos impressos os salvos em seus tablets e demais aparelhos. Além disso, posto material complementar e tiro dúvidas on line

RP6 Essencial. Uma logística pedagógica a meu ver indispensável. Prático, rápido, objetivo, facilita a relação tempos e movimentos, ágil, funcional, de grande alcance, retorno rápido, facilita o processo acadêmico e pedagógico de funcionamento da disciplina.

RP7 Fundamental, pois as práticas digitais constituem a produção acadêmica.

RP8 Não é o objetivo desse canal, portanto não vejo relação.

RP9 Para mim é fundamental, sobretudo porque desenvolvi uma metodologia de correção de textos com instruções gramaticais, semânticas, estilísticas etc. para reescritura. Essa prática é desenvolvida com ao auxílio dos e-mails e anexação de arquivos, além da exploração de recursos digitais de editor de textos.

RP10 Embora as ferramentas, presentes no "canal virtual", sejam importantes, elas só serão consideradas recursos pedagógicos fundamentais quando o professor e aluno conseguiram utilizá-las de modo produtivo. Ou seja, quando os recursos disponíveis no "canal virtual" (correios, fórum, chat, blog e outros) favorecerem as competências de leitoras e escriturais. Não considero que o canal virtual, por ele mesmo, apoie o 
ensino da produção de texto acadêmico. O professor deve utilizar os recursos disponíveis, nesse "canal virtual", para delinear metodologias que promovam as competências de leitura e escrita.

A leitura das respostas obtidas faz entender que o canal virtual não é unanimemente aprovado como instrumento didático de apoio ao ensino de produção de texto acadêmico. Há os que não enxergam essa relação, mas há os que a consideram fundamental, citando que a produção acadêmica é constituída pelas práticas digitais e que algumas atividades, como a correção de textos para reescritura, são facilitadas pelos recursos digitais disponíveis como os editores de texto. Alguns ainda apontam para a rapidez comunicativa do email, mas o veem como ferramenta limitada.

Pode-se verificar, contudo, que a maioria dos Respondentes Professores aprova a utilização dos meios virtuais como apoio ao ensino de texto acadêmico, destacando a praticidade em questões de mobilidade, (multiplicação de) tempo e espaço, sem deixar de ressaltar a necessidade de planejar metodologias próprias para que tais recursos realmente promovam e desenvolvam as competências linguísticas desejadas.

Pode-se dizer que as informações e posições obtidas por meio das questões dirigidas a professores universitários sinalizam para a valorização do ensino de produção de texto acadêmico, como promotor de competências que auxiliam a aprendizagem dos saberes acadêmicos em geral. Além disso, também indicam que os pesquisados consideram adequado o uso do ambiente virtual como instrumento colaborador complementar a tal ensino. Observar tais posições faz perceber que há, entre os docentes, a intuição de que associar às práticas presenciais a interação por meio de ambiente virtual pode auxiliar o processo pedagógico, mas que essa associação ainda não ocorre de maneira totalmente satisfatória.

O fato de ainda não se conhecerem aplicações ou resultados de iniciativas que proponham combinar práticas presenciais e virtuais no ensino de produção de texto acadêmico de modo planejado vem ao encontro da concepção e aplicação da proposta do presente estudo. Trata-se de combinar planejadamente determinadas atividades presenciais e virtuais, segundo suas características interativas e potencial cognitivo, para que se obtenham resultados significativos no ensino de produção textual.

No capítulo seguinte, são examinadas questões de interação e cognição que permeiam as atividades presenciais e aquelas mediadas por computador no âmbito do ensino de produção textual, visto ser o processo de ensinar e aprender eminentemente interativo. A 
finalidade de tal abordagem é sugerir a provável adequação, ou maior efetividade, em desenvolver cada prática em ambientes presenciais ou virtuais, valendo-se de uma observação das características de cada ambiente em correspondência às atividades pedagógicas a serem desenvolvidas. 


\title{
CAPÍTULO 2
}

\section{Os ambientes}

\section{presenciais e virtuais de}

aprendizagem - estudos

\author{
sobre interação e \\ cognição
}


Os temas desenvolvidos neste capítulo decorrem dos resultados da pesquisa realizada junto aos professores, os quais nos levam a buscar subsídios teóricos para justificar a ideia de uma proposta de ensino de escrita acadêmica que se utilize da combinação de características interacionais dos ambientes presenciais e virtuais de aprendizagem e, dessa maneira, torne possíveis abordagens multimodais e multissensoriais, assim aumentando as possibilidades de mesclagens conceituais ou articulações cognitivas e, como consequência, promover uma construção de conhecimento de forma mais abrangente.

O exame dos aspectos interacionais, em particular sobre os processos interativos de professores e alunos constituintes do ensino de texto acadêmico no ensino superior, contempla tanto a interação presencial, face a face, como também aquela mediada por computador, a distância. Serão também examinadas posições de diversos autores sobre o impacto que as novas tecnologias podem ter no campo do ensino, observando particularmente o uso da internet e dos ambientes virtuais de aprendizagem, os AVAs.

Neste capítulo, abordaremos ainda a posição de alguns estudiosos da cognição que se ocupam com conhecer como se dá a construção de sentido e de conhecimento em geral, nos processos de ensino e aprendizagem e, mais especificamente, nas atividades que envolvem produção textual em língua portuguesa. Parece também pertinente explicitar a perspectiva linguística sob a qual se fundamenta essa proposta, assumida por a considerarmos adequada a uma situação de construção colaborativa de conhecimento, o que será feito a seguir.

\subsection{Perspectiva linguística e interação}

\subsubsection{Perspectiva textual-interativa}

Acreditar que os processos de ensino e aprendizagem que envolvem a produção textual devem ser abordados em suas características interacionais está relacionado à convicção de que tais processos só ocorrem de forma efetiva se houver interação dos sujeitos envolvidos, numa ação dialógica contínua em que todos, nesse caso professores e alunos, constroem sentidos e conhecimentos de forma conjunta. No caso específico de nossa abordagem, o ensino de artigo científico em Língua Portuguesa, importa ainda dizer que a perspectiva linguística adotada é a sociointerativa situada, de acordo com Marcuschi (2008). 
Tal como o autor citado, para este estudo também se considera a língua como "um conjunto de práticas sociocognitivas e discursivas" (p. 56), relacionadas aos aspectos históricos. Marcuschi (2008, p. 60) assim justifica sua opção:

Essa posição toma a língua como uma atividade sociohistórica, uma
atividade cognitiva e atividade sociointerativa. Na realidade, contempla a
língua em seu aspecto sistemático, mas observa-a em seu funcionamento
social, cognitivo e histórico, predominando a ideia de que o sentido se
produz situadamente e que a língua é um fenômeno encorpado e não abstrato
e autônomo. Não ignora a forma sistemática nem deixa de observar a
regularidade sistemática.

Como modo de aprofundamento dessa noção de língua, Marcuschi (2008) acrescenta que trabalha com a perspectiva textual-interativa, mas não se esquece de que a língua é um sistema simbólico. Esse autor toma a língua como "um conjunto de práticas sociais e cognitivas historicamente situadas", mas abertas, flexíveis, criativas e sensíveis à realidade sobre a qual atua, enfim "um sistema de práticas com o qual falantes/ouvintes (escritores/leitores) agem e expressam suas intenções com ações adequadas aos objetivos em cada circunstância”. (MARCUSCHI, 2008, p. 61)

Ao deslocar o foco único no código linguístico para o funcionamento linguístico, ou seja, a análise de textos e discursos, ensinar a língua será conduzir ao desenvolvimento de competências discursivas funcionalmente adequadas (grifo do autor), dentre as quais também se encontra a competência linguística. Marcuschi (2008, p. 65) lembra que a língua é impregnada pelo discurso, portanto não se esclarece o pleno funcionamento de um texto apenas no âmbito da língua, é preciso considerar também aspectos sociais e cognitivos, admitindo que "a língua é uma atividade interativa, social e mental que estrutura nosso conhecimento e permite que nosso conhecimento seja estruturado".

Crê-se que a perspectiva linguística assumida está em acordo com uma proposta de ensino de produção textual que aborde a língua em funcionamento, sem desprezar suas regularidades sistemáticas, por meio da utilização do gênero como instrumento de ensino, mediante um processo didático dialógico e modular passível de constante reformulação, inspirado nas sequências didáticas descritas por Dolz, Noverraz e Schneuwly (2004), conforme tratamos no Capítulo 3 deste estudo. Portanto, observar os aspectos interativos inerentes a tal abordagem torna-se essencial, pois seja a atividade linguística durante o processo, seja a produção textual propriamente dita, ambas só se dão pela interação. 
2.1.2 Interação como fenômeno e interação na sala de aula presencial

Em se tratando de interação, Brait (2003, p. 235) caracteriza-a de modo geral como fenômeno sociocultural componente dos processos de significação e de construção de sentido, o qual faz parte de todo ato de linguagem, que acontece, necessariamente "entre dois falantes que se caracterizam como atores da interlocução e que vão se relacionar enquanto parceiros”, revezando-se na condição de sujeito comunicante e sujeito interpretante.

Fávero, Andrade e Aquino, (1998, p. 93) afirmam que as características da interação, de forma generalizada, incluem um contexto, um campo de ação e indivíduos atuantes. Segundo as autoras:

(...) a interação caracteriza-se por situar-se em um contexto em cujo âmbito se estabelece um campo de ação comum no qual os sujeitos envolvidos podem entrar em contato entre si. Torna-se, portanto, fundamental a capacidade de ação de cada indivíduo, que deve estar apto a influir no desenvolvimento sucessivo da interação, determinando-o com sua atuação: cada ação de um sujeito deve constituir a premissa das ações realizadas posteriormente pelos demais.

Em concordância com essas estudiosas, ao examinar o contexto em que se situa a presente proposta de ensino, pode-se dizer que ela estabelece dois campos de ação comum, a sala de aula presencial e o ambiente virtual em que são desenvolvidas as atividades mediadas por computador, ampliando a possibilidade de os sujeitos envolvidos, neste caso professor e alunos, entrarem em contato e, assim, influenciarem o desenvolvimento da interação.

Koch (1992 [2007], p. 10), ao tratar mais particularmente da interação pela linguagem, define-a como "a capacidade que tem o ser humano de interagir socialmente por meio de uma língua, das mais diversas formas e com os mais diversos propósitos e resultados”. Concluindo essa obra, a autora argumenta que não se pode estudar a língua apenas como um código, um sistema formal abstrato ou um conjunto de enunciados virtuais, cujo significado se dá fora de contexto, pois a linguagem é:

(...) lugar onde os indivíduos se representam e constituem o mundo e suas situações ao se constituírem e representarem de determinada forma. (...). É preciso pensar a linguagem humana como lugar de interação, de constituição de identidades, de representação de papéis, de negociação de sentidos, portanto de co-enunciação.

Em outras palavras, é preciso encarar a linguagem não apenas como representação do mundo e do pensamento ou como instrumento de comunicação, mas sim, acima de tudo, como forma de inter-ação social. (KOCH, 1992 [2007], p. 128) 
Em concordância com a ideia de que os sentidos são construídos e negociados de forma colaborativa e dialógica, Silva (2002), ao observar a interação no âmbito escolar, afirma que o texto interacional é “co-construído" em sala de aula pelos “interactantes", professor e alunos, que possuem motivação, finalidade, relações de lugares e papéis sociais específicos, porém complementares, em uma abordagem em que não se separam o verbal e o social. A relação em que estão envolvidos os sujeitos, numa situação de ensino, pode ser caracterizada como especializada, com finalidade preestabelecida e assimétrica, englobando "ações do professor, reações dos alunos a essas ações, reações do professor às ações dos alunos e reações dos alunos entre si”, num processo colaborativo que requer constantes negociações e ajustes, como em todo evento interativo. (SILVA, 2002, p.185)

De fato, uma questão de interesse para esse estudo é que, apesar de diversos autores apontarem que a organização interacional prevê algumas regras e padrões de comportamento que funcionem como orientação para a competência interpretativa e persuasiva dos indivíduos atuantes em determinado evento interacional (BRAIT, 2003, p. 235), na mecânica da interlocução "o sujeito interpretante não reconstrói pura e simplesmente as significações produzidas pelo sujeito comunicante". Com o revezamento das posições entre os sujeitos, ora falantes, ora ouvintes, há a contínua participação no projeto de construção de sentido do outro, dimensionando a interação como conjunto de movimentos coordenados de uma atividade cooperativa.

Ao transferir essa característica da mecânica da interlocução para a situação de sala de aula, parece ajustado dizer que, na interação professor e aluno, também é preciso considerar que não há uma simples reconstrução do que o professor diz por parte dos alunos. O que há é uma contínua articulação e negociação de sentidos, numa atividade colaborativa nem sempre livre de conflitos, já que há a interferência de questões sociais e culturais que também devem ser levadas em consideração. A questão da assimetria, que, segundo Silva (2002, p. 185), estabelece-se com o professor em posição superior de comando e o aluno em posição inferior correlativa, sob o ponto de vista da proposta aqui apresentada, que se refere à aprendizagem no ensino superior, deve ser constantemente enfrentada e revista, caso se deseje promover um processo colaborativo de construção de conhecimento.

Ao considerar aspectos da situação de sala de aula como evento comunicativo que tem por base a interação professor/alunos e, portanto, constrói relações sociais, seria possível afirmar que uma interação bem-sucedida pode produzir mais linguagem significativa e, por 
conseguinte, maximizar o processo cognitivo. Tal circunstância se deve ao fato de que a linguagem seria utilizada como forma de construir e reconstruir conhecimento, por meio de constante articulação entre o discurso do saber estabelecido e a procura de soluções alternativas.

Estudiosos da escrita científica em um segundo idioma, Bazerman, Keranen e Prudêncio (2012, p. 242) afirmam que, em questões de aprendizagem de uma língua, quando somos desafiados, a nossa competência linguística aumenta, pois incorporamos a linguagem que ouvimos em nosso ambiente, assim descobrindo e exercitando novas ideias e formulações linguísticas. Para eles, a linguagem é construída dialogicamente. ${ }^{13}$ Assumimos, como esses autores, que um ambiente de aprendizagem desafiador, seja ele presencial ou virtual, em que a interação seja otimizada e se promova a descoberta e o uso de novas habilidades linguísticas, também é próximo do ideal quando se trabalha com a língua materna, em nosso caso, a língua portuguesa.

Em estudo desenvolvido sobre a interação em sala de aula presencial, Silva, Barzotto e Ramos (2010, p. 200) reconhecem que os conflitos, próprios do jogo interacional, também acontecem no ambiente escolar, situação da qual professores e alunos devem estar cientes. Para esses autores, perceber e analisar os conflitos em que se envolvem os participantes da cena escolar também é parte importante da aprendizagem, mas não apenas isso, é preciso que todos estejam dispostos a restabelecer sempre as condições para uma interação cooperativa, assim garantindo um espaço favorável ao ensino.

Nas interações face a face, linguagem, entonações, gestos e expressões corporais podem auxiliar na solução de conflitos em tempo real, de forma mais imediata. Nas interações virtuais, por sua vez, em particular nos ambientes virtuais de aprendizagem utilizados para as práticas pedagógicas aqui propostas, que em geral não incluem interação em tempo real, a linguagem, em sua modalidade escrita, é praticamente a única forma de resolver impasses e retomar uma interação cooperativa. Por esse motivo, em termos interacionais, importa ressaltar que a linguagem empregada em comentários e fóruns, quando houver, merece ser bastante cortês, sempre promovendo a atitude colaborativa em torno da construção do conhecimento. Considerações sobre a linguagem utilizada para propor atividades, comentar tarefas ou mediar fóruns serão mais aprofundadas na seção que segue, sobre o uso das novas

13 Tradução adaptada de: When we are met by challenge, our language grows as we incorporate language we hear around us, discover new things to say, and reach toward new formulations and ideas. (...) ... language use is typically constructed dialogically ... 
tecnologias na educação e no Capítulo 4, que apresenta o desenvolvimento da proposta de ensino de artigo científico e a análise das seções que a compõem.

Levadas em conta as posições quanto à interação desenvolvida em sala de aula presencial defendidas pelos autores mencionados, entre tantos outros que estudam o tema, pode-se dizer que, ao cuidar para que a interação inerente à situação de ensino ocorra sempre de forma colaborativa, pode-se contribuir enormemente para o sucesso das atividades de ensinar e aprender, principalmente quando, como no caso das práticas aqui propostas, objetiva-se uma construção cooperativa e reflexiva de conhecimento. A ocorrência de conflitos, situação habitual tanto nas interações face a face quanto naquelas mediadas pelos meios eletrônicos, deve transformar-se em oportunidade de reformulação e reflexão sobre o processo educativo, uma forma de aperfeiçoamento, conforme observam os estudiosos anteriormente mencionados.

Como nesta pesquisa interessa conhecer os aspectos interacionais referentes aos dois ambientes pesquisados, o presencial e o virtual, para definir quais atividades didáticas que fazem parte da proposta de ensino de artigo científico podem ser mais adequadamente desenvolvidas em cada um desses locais, observamos a seguir a posição de alguns autores sobre as transformações que o uso das novas tecnologias estão operando no campo do ensino, caracterizando ainda alguns tipos particulares de ambientes virtuais de aprendizagem e examinando aspectos da interação desenvolvida em tais ambientes, sempre tendo em mente as situações de ensino.

Cabe aqui uma reflexão sobre as palavras de Kenski (2003, p. 120), com respeito à interação que ocorre em qualquer prática que objetive ensinar:

Não sei dizer até que ponto vamos estar falando de novos processos de interação e de comunicação, ou se falamos dos mesmos processos, de uma nova ótica. Ou seja, falamos da mediação realizada pelas tecnologias (sejam elas relativamente novas, como o telefone, o fax, o celular, ou das mais recentes tecnologias digitais e suas possibilidades hipermidiáticas de comunicação através da Internet), para aproximar pessoas, possibilitar que interajam e se comuniquem, com o objetivo, no nosso caso, de ensinar e aprender.

Ao refletir sobre interação no ensino, assumimos que não se pode dizer que haja oposições entre a interação que ocorre face a face e aquela em ambiente virtual. Parece-nos mais adequado dizer que são formas complementares de interagir. De qualquer maneira, a interação de que tratamos sempre ocorrerá com seres humanos e, para que a atividade 
pedagógica seja eficiente, crê-se que quanto mais intensa e colaborativa ela seja, melhores serão os resultados.

2.1.3 Uso das novas tecnologias na educação: interação e linguagem

As transformações que o surgimento das novas tecnologias da informação e comunicação estão provocando nas sociedades ao redor do mundo, seja em seus modos de organização, de produção e comercialização de bens, de diversão, seja na maneira de ensinar e aprender, estão sendo observadas e estudadas por inúmeros pesquisadores. A presente pesquisa se insere nesse conjunto de estudos, pois busca, ao defender a validade do ensino de escrita acadêmica como forma de promover uma aprendizagem mais crítica e consciente dos saberes acadêmicos em geral, ilustrar de que forma a combinação de atividades realizadas em ambientes presenciais e virtuais pode ser proveitosa para o sucesso do ensino de produção de artigo científico. Seguem algumas posições que entendemos serem relevantes, propostas por estudiosos de temas que convergem práticas educativas e tecnologias de informação, que inspiraram o presente trabalho.

Ao utilizar a metáfora de 'rede' que vai envolvendo e conectando tudo a todos, "um novo espaço de comunicação, de sociabilidade, de organização e de transação, mas também novo mercado da informação e do conhecimento" para definir o ciberespaço, Lévy (1999, p. 32) chama a atenção para a fusão de culturas nacionais em uma cultura globalizada e cibernética, a cibercultura. Ele adverte que qualquer política de educação deverá levar em conta o surgimento de novos gêneros de conhecimento, de critérios inéditos de avaliação do saber e de novos atores na produção e no tratamento dos conhecimentos, por conta do novo suporte de informação e comunicação que é o ciberespaço. (p. 170)

Numa breve retomada da posição de Toffler (1980) sobre a sucessão de eras ou 'ondas' vivenciadas pelo homem, cujas características determinam seu futuro, Passarelli (1995), em estudo que alia a Teoria das Inteligências Múltiplas à Multimídia na Educação, nos diz que, durante aproximadamente 6000 anos, na era (ou onda) agrícola, a vida e seus valores aconteciam em função da organização do alimento. Depois vieram a era industrial, seguida pela era da informação. Relacionando a educação às eras industrial e de informação, Passarelli (1995, p. 151) afirma: 
Enquanto na era industrial a ênfase está no produto, com a educação centrada no ensino do fato, na era da informação a ênfase se deslocou para a prestação de serviços, com a educação voltada para a formação de alunos capazes de construir sua própria aprendizagem.

Essa pesquisadora da ECA-USP acrescenta que a escola não pode ignorar as profundas transformações que os meios e tecnologias de comunicação introduziram em nossa sociedade, criando novas maneiras de "apreender" e "aprender" o mundo, e enumera interatividade, mobilidade, convertibilidade, interconectividade, globalização e velocidade como atributos desses meios. Ainda de acordo com Passarelli (1995, p. 152), se a escola quiser sobreviver como "instituição geradora, mantenedora e delegadora do saber humano", precisa digerir e incorporar a multiplicidade de pontos de vista e a riqueza de leituras que as novas tecnologias trazem.

Em se tratando dos novos paradigmas para a educação, Passarelli (1995, p. 153) propõe que eles devem contemplar a preparação de alunos que possam conviver numa sociedade em constantes mudanças e se tornar construtores do próprio conhecimento, “portanto, serem sujeitos ativos deste processo onde a 'intuição' e a 'descoberta' são elementos privilegiados desta construção. " Para que essa preparação seja bem-sucedida, essa autora ainda adverte que o aluno deve ser visto como um ser total, possuidor de diversas inteligências, não só a linguística e a lógico-matemática, como também a espacial, a corporal, a musical, a interpessoal e a intrapessoal, que devem ser desenvolvidas igualmente, para que ele possa interagir com os novos meios e tecnologias e "aprender" o mundo por meio de múltiplos pontos de vista.

No cenário internacional, Caroline Haythornthwaite e Richard Andrews (2011), ela professora das universidades de Columbia e Illinois e ele, de métodos de pesquisa online na University of London, com reputação internacional em pesquisa, entre outros temas, sobre o impacto do computador e da internet no ensino e na interação social, são autores de obra que aborda as implicações sociais e o efeito transformador e interativo do ensino mediado por computador, explorando as mudanças que aconteceram no ensino e na aprendizagem com a presença da internet. Na introdução dessa obra, eles observam:

As formas como aprendemos, com quem e por quais meios estão mudando. $\mathrm{E}$ as rápidas mudanças em conhecimento e tecnologia pedem por novas abordagens para disseminação e integração de novas informações em locais de trabalho e práticas profissionais, além de novos caminhos para a 
aprendizagem de adultos. A educação não é menos afetada. (HAYTHORNTHWAITE e ANDREWS, 2011, p. 1) ${ }^{14}$

Como forma de responder à pergunta sobre como as tecnologias da informação e da comunicação estão criando novas condições e oportunidades no ambiente de ensino e aprendizagem, Haythornthwaite e Andrews (2011, p. 6) afirmam que a primeira circunstância óbvia a ser considerada é o aumento do uso da comunicação eletrônica no cotidiano de todos, amparado num maior e facilitado acesso à internet por meio de uma combinação de dispositivos móveis (laptops, celulares e smartphones) e infraestrutura de comunicação (de banda larga e sem fio), que tornam disponível uma biblioteca cada vez maior de formatos eletrônicos (artigos, livros, notícias, músicas, filmes e vídeos). (HAYTHORNTHWAITE e ANDREWS, 2011 p. 6$)^{15}$

Tal situação também ocorre em nosso país, onde houve um grande progresso em termos de acesso à internet, combinando a popularização de dispositivos fixos e móveis, como os computadores pessoais, os celulares e os smartphones, à implantação do sistema sem fio (wireless) de acesso à internet por banda larga, possibilitando ao usuário, aqui particularmente o estudante, acesso a documentos em formato eletrônicos diversos para realizar suas pesquisas e estudos. A proliferação de revistas científicas em formato eletrônico, um dos principais canais nacionais e internacionais de publicação da pesquisa acadêmica não passa despercebida, nem a questão da produção de textos acadêmicos em ambiente virtual, hoje quase na sua totalidade escritos em computador.

Comentando um outro aspecto da influência que a tecnologia exerce nas dimensões temporais e espaciais em que o ser humano 'moderno' se insere, Charaudeau (2008, p. 215), quando aborda a questão dos imaginários de verdade, define o imaginário da "modernidade" como 'um conjunto de representações que os grupos sociais constroem a propósito da maneira como percebem ou julgam seu instante presente, em comparação com o passado, atribuindolhe um valor positivo, mesmo quando o criticam. " (CHARAUDEAU, 2008, p. 215)

${ }^{14}$ Tradução livre de: How we learn, with whom, and by what means is changing. Rapid changes in knowledge and technology are driving the need for new approaches to dissemination and integration of new information into work places and work practices, and new learning paths for adults. Education is no less affected. (HAYTHORNTHWAITE e ANDREWS, 2011, p. 1)

15 Tradução livre de: The first obvious trend is the increased use of electronic communication in our daily lives, supported through increased access to the Internet via a combination of mobile devices (laptops, mobile and smart phones) and communication infrastructures (broadband and wireless) and providing access to a growing library of information in electronic formats (articles, books, news, music, movies and vídeos). (HAYTHORNTHWAITE e ANDREWS, 2011 p. 6) 
Ao falar sobre modernidade e tecnologismo, esse autor afirma que os discursos sobre tecnologia são portadores de um imaginário de verdade ligado às noções de eficácia, competência e vontade de agir e que, portanto, supõe-se que "a técnica constrói ferramentas que permitem gerir de maneira mais eficaz possível a criação e circulação de riquezas”, de modo que o progresso técnico geraria o progresso social. $\mathrm{O}$ autor comenta como nossa época é marcada por diferentes modos de organização nas dimensões de tempo e espaço:

Nossa época (fim do século XX e início do século XXI) é marcada pela tecnologia da comunicação, pela fabricação de modos de transmissão sofisticados (eletrônicos, digitais) e por uma organização das conexões em rede que permitem ao mesmo tempo fazer circular a informação em um tempo próximo daquele da palavra oral e colocar em contato direto pessoas que se encontram muito distantes umas das outras. (CHARAUDEAU, 2008, p. 225)

Sem dúvida, as transformações quanto às questões de tempo e espaço são as mais perceptíveis no ambiente virtual, o que se aplica também ao ensino mediado por computador. Os 'ambientes' virtuais de aprendizagem em que são veiculadas as atividades a distância mantêm apenas uma ligação metafórica de sentido com a plataforma literal, dicionarizada: "uma superfície plana e horizontal, de nível mais alto que a área circulante", já que eles constituem um espaço virtual, eletrônico, acessado de qualquer computador, celular ou tablet. Além disso, em grande parte dos cursos ministrados virtualmente, o 'tempo' de uma aula também não é necessariamente o mesmo para professor e alunos, com exceção das ocasiões em que são marcados encontros online com finalidades específicas como tirar dúvidas.

Entretanto, diversos outros temas relacionados aos ambientes virtuais, principalmente sobre cognição, começam a ser objeto de estudo de muitos autores na área de educação. Quevedo, Geraldini, Rodrigues e Crescitelli (2006) já se dedicam a estudos nessa área aqui no Brasil, em especial sobre a formação de profissionais que atuem na área de ensino a distância. Elas afirmam que:

As tecnologias de informação e comunicação (TIC) atingem todas as camadas sociais e os mais diversos setores. Novas formas de pensar e de apreender o mundo surgem em consequência da atuação de variadas comunidades virtuais e da forma como as redes possibilitam a articulação da informação e de processos sociais a distância. Todos esses avanços tecnológicos se refletem em mudanças marcantes que influenciam e revolucionam o conceito de informação e conhecimento e a forma de aprender. (QUEVEDO, GERALDINI, RODRIGUES e CRESCITELLI, 2006, p.198) 
De fato, uma nova 'cultura' em termos de ensino está nascendo com a possibilidade de interagir com alunos por meio de ambientes virtuais, tornando-se uma realidade a Educação em Ambientes Virtuais de Aprendizagem (AVA), que conquista espaço significativo, conforme afirma outro grupo de pesquisadoras, Marquesi, Cabral, Elias e Vilela (2010, p. 354). Essas estudiosas investigam a nova modalidade de ensino e refletem sobre como os meios digitais podem ser pensados no e para o ensino dentro de uma visão de leitura e escrita, já que, para elas, no ensino em meios digitais:

- O aluno assume o papel de um leitor que, por meio da interação com o texto escrito, construirá seu conhecimento;

- O professor assume o papel de um escritor que, por meio do texto escrito, possibilitará, ao aluno, a construção de seu conhecimento. (MARQUESI, CABRAL, ELIAS e VILELA, 2010, p. 355)

Entre as questões abordadas por Marquesi, Cabral, Elias e Vilela (2010), nesse e em diversos outros trabalhos, está a organização da linguagem que promove a interação entre professor e aluno, de extremo interesse para a realização de nossa proposta de produção de artigo científico por meio da combinação de práticas em ambientes presencial e virtual, que considera a linguagem tanto prática sociointerativa quanto agente promovedor da aprendizagem. Ponderamos que as atividades realizadas em ambiente virtual por meio de comunicações escritas - a postagem de conteúdos e atividades didáticas ou as mensagens, revisões e comentários - precisam ser elaboradas de modo a expressar, resumida e claramente, seus objetivos e, no caso das mensagens e comentários, tornar o professor o mais próximo possível de seu destinatário, o aluno, conforme indicam as autoras. (MARQUESI, CABRAL, ELIAS e VILELA, 2010, p. 381).

Interessado em estudar diferentes aspectos do uso de novas tecnologias na escola, Moran (2012, p. 12), professor e pesquisador da Universidade de São Paulo, considera que "ensinar e aprender são os desafios maiores que enfrentamos em todas as épocas e particularmente agora em que estamos pressionados pela transição do modelo de gestão industrial para o da informação e do conhecimento". Ele afirma que, com as mudanças que estão tornando a sociedade mais interconectada, muitas formas convencionais de dar aulas já não se justificam mais, porém adverte que ensinar não depende só do uso de tecnologias, um posicionamento com o qual este estudo concorda. Ele observa que:

Sem dúvida as tecnologias nos permitem ampliar o conceito de aula, de espaço e tempo, de comunicação audiovisual, e estabelecer pontes novas entre o presencial e o virtual, entre o estarmos juntos e o estarmos conectados a distância. Mas, se ensinar dependesse só de tecnologias, já 
teríamos achado as melhores soluções há muito tempo. Elas são importantes, mas não resolvem as questões de fundo. (MORAN, 2012, p.12)

Quando Moran (2012, p. 18) aborda o tema da construção do conhecimento na sociedade da informação, ele define conhecer como "compreender todas as dimensões da realidade" e afirma que conhecemos melhor quando conectamos, juntamos, relacionamos e acessamos o nosso objeto (de conhecimento) de todos os pontos de vista. Para o autor, processamos a informação de várias formas, sendo a mais habitual o processamento lógicosequencial, que se expressa na linguagem falada e escrita, em que a construção de sentido acontece aos poucos, num ritmo mais lento, em sequência espacial ou temporal, dentro de um código definido, a língua.

Em outros momentos, processamos a informação de forma hipertextual - contando histórias, relatando situações que se interconectam, levando-nos a novos significados importantes. É o que o autor chama de comunicação "linkada", que prevalece em meios de comunicação como a televisão, que usa a narrativa com várias linguagens superpostas, valorizando uma forma atraente, rápida e sintética de lidar com a informação. Na atualidade, entretanto, a maneira mais comum de processarmos a informação, em virtude da rapidez com que temos de enfrentar situações diferentes a cada momento, é a multimídica, que agrega segmentos de textos de várias linguagens superpostas simultaneamente, de forma mais livre e com conexões que passam pelo sensorial, pelo emocional e pela organização do racional. (MORAN, 2012, p. 20)

Ao relacionar essas formas de processar conhecimento ao ensino, Moran (2012, p. 22) afirma:

Uma das tarefas principais da educação é ajudar a desenvolver tanto o conhecimento de resposta imediata como o de longo prazo; tanto o que está ligado a múltiplos estímulos sensoriais como o que caminha em ritmos mais lentos, que exige pesquisa mais detalhada, e tem de passar por decantação, revisão, reformulação.

A posição de Moran quanto à necessidade de a escola desenvolver e aperfeiçoar igualmente todas essas formas de processamento de informação coincide com a postura adotada nesta pesquisa, já que propõe combinar atividades presenciais e virtuais para ensinar a produzir o artigo científico, apresentando-o sob diversos pontos de vista, para que o aluno possa construir seu conhecimento em relação a essa prática por meio de vários caminhos, prevalecendo, porém, aqueles ligados ao processamento lógico-sequencial, de ritmo mais 
lento, dentro do código que é a língua. Como o próprio Moran (2012, p.22) afirma, em texto mencionado anteriormente, o conhecimento de longo prazo exige pesquisa detalhada e precisa passar por revisão e reformulação, posição igualmente assumida por muitos outros autores e também pelo presente trabalho.

Seja ao considerar as posições dos diversos autores aqui mencionados sobre a possibilidade de incorporar novas tecnologias à educação em geral, seja ao contemplar os já mencionados resultados dos questionários respondidos por professores e alunos em relação à aprovação dos meios virtuais como apoio ao ensino de produção textual, cada vez mais nos parece justificada a proposta de combinar as tradicionais aulas presenciais, em que se dá a interação face a face, com a utilização de ambientes virtuais de aprendizagem. Servem ao propósito de caracterizar tais ambientes, os tradicionais e os virtuais, as considerações que vêm a seguir.

2.1.4 Ambientes complementares de ensino: o presencial e o virtual

Kenski (2003), ao comentar as atividades didáticas realizadas em ambientes presenciais e naqueles a distância, prefere usar a palavra ensino, por considerar educação um termo muito abrangente, referente a atos, pensamentos e desejos do indivíduo que manifesta a compreensão do que lhe falta em todos os momentos de sua vida. Sendo assim, a autora afirma ser o ensino presencial desencadeado "nos espaços específicos em que as pessoas se encontram fisicamente, olham-se, tocam-se e experimentam a proximidade de seus corpos em um mesmo ambiente em que ocorre o ato presencial de ensinar". Em relação ao ensino $a$ distância, indica ser aquele que se aproveita "das múltiplas formas de interação, comunicação e acesso à informação oferecidas pelas novas tecnologias digitais de informação e comunicação." (KENSKI, 2003, p. 12)

Essa estudiosa das questões de ensino em geral e em particular daquelas que envolvem o uso das novas tecnologias, considera o espaço uma das linguagens mais poderosas para expressar as práticas escolares, pois ele é condicionador da proposta de ensino a ser desenvolvida. Enquanto na escola tradicional a distribuição dos ambientes no espaço escolar, a arrumação e o uso de móveis e equipamentos definem a ação pedagógica, pois se refletem na disposição para trabalhar e estudar; a escola virtual, fluida e mutante, apresenta-se por sua imagem exposta na tela do computador. (KENSKI, 2003, p. 54) 
Complementando sua posição, Kenski (2003, p. 55) diz:

(...) os espaços das escolas virtuais se estruturam essencialmente como linguagens. Local em que se partilham fluxos e mensagens para a difusão dos saberes, o ambiente virtual de aprendizagem se constrói com base no estímulo à realização de atividades colaborativas, em que o aluno não se sinta só, isolado, dialogando apenas com a máquina ou com um instrutor, também virtual. Ao contrário, construindo novas formas de comunicação, o espaço da escola virtual se apresenta pela estruturação de comunidades online em que alunos e professores dialogam permanentemente, mediados pelos conhecimentos.

Essa pesquisadora entende que "O ambiente educacional virtual não suprime o espaço educacional presencial. Ao contrário, ele o amplia. ", pois várias situações de ensino, como os projetos de educação permanente ou cursos diversos oferecidos em qualquer nível de ensino, podem se beneficiar das novas possibilidades de comunicação e agregação por meio das redes, o que significa avanço "na ação e na formação do cidadão que habita os múltiplos espaços das escolas - e das suas múltiplas linguagens. ” (grifo da autora) (KENSKI, 2003, p. 68)

De qualquer forma, acreditamos ser preciso considerar que, embora espaços e tempos tenham sido estendidos pela tecnologia dos ambientes mediados pelo computador, quando se trata de educação e construção de conhecimento por esses meios, a constituição de novas formas de comunicação, a difusão dos saberes e a realização de atividades colaborativas - em nosso caso na área da produção textual - só se dão mediante o criterioso e flexível planejamento das atividades pedagógicas, e a mediação atenta, desafiadora e cortês do professor como forma de estímulo à constante participação do aluno, sem a qual o processo é incompleto.

Apoiando-nos ainda em Kenski (2003, p. 55), quando essa autora diz que as "escolas virtuais" estão em permanente mudança, refletindo e apresentando novas formas de linguagem e cultura do momento tecnológico atual, acreditamos ser importante conhecer o funcionamento adequado do ambiente virtual, também chamado digital, para contribuir com o aprendizado e estimular o aluno a participar ativamente do processo educativo. A sensação de isolamento ou de estar se relacionando com uma máquina, como citou anteriormente Kenski (2003, p. 55), são exatamente opostas ao processo colaborativo que se deseja implantar com a presente proposta pedagógica de ensino de texto acadêmico. Passamos, a seguir, ao exame das características do ambiente virtual de aprendizagem. 
2.1.4.1 Digital ou virtual? Conceito e funcionamento de um ambiente digital

Em virtude de os termos 'virtual' e 'digital' serem usados neste estudo como sinônimos, o que, neste caso parece pertinente, julga-se necessário examinar suas definições para que seja facilitada a compreensão da estrutura de um Ambiente Virtual de Aprendizagem (AVA), como um dos meios para que se aplique a presente proposta de produção textual no ensino superior.

Lévy ${ }^{16}$ (1999, p. 52) esclarece, em obra dedicada ao estudo da cultura globalizada, que "Digitalizar uma informação consiste em traduzi-la em números." Ele acrescenta que a correspondência entre letras e números permite que qualquer texto escrito possa ser transformado em uma sequência de números; que uma imagem pode ser transformada em pontos ou pixels e cada um deles descritos em números; que os sons também podem ser digitalizados por amostragem e representados por uma série de números. Em geral, é possível traduzir digitalmente, em linguagem binária sob a forma de 0 e 1, qualquer informação que possa ser explicitada ou medida. A linguagem binária, por sua vez, presta-se à gravação, transmissão e depois à cópia, quase indefinidamente e sem perda, por vários dispositivos técnicos.

Após terem sido tratadas, as informações codificadas em linguagem binária serão traduzidas no sentido inverso, manifestando-se como textos legíveis, imagens visíveis, sons audíveis, etc. É por estarem codificadas em números, estes estarem sujeitos a cálculos e o computador calcular rapidamente, que podemos manipular as informações digitalizadas com grande facilidade. Lévy (1999, p. 54) acrescenta: “A informação digitalizada pode ser processada automaticamente, com um grau de precisão quase absoluto, muito rapidamente e em grande escala quantitativa. ", e conclui que o computador não é só "uma ferramenta a mais para a produção de textos, sons e imagens, é antes de mais nada um operador de virtualização da informação.", uma constatação replicada no caso dos ambientes digitais/virtuais de aprendizagem, por meio dos quais professores, monitores e grupos de estudantes podem acessar grande quantidade de informação digitalizada e também colaborar inserindo suas produções, comentários e mensagens.

\footnotetext{
${ }^{16} \mathrm{PhD}$ em Ciências da Informação e da Comunicação pela Universidade de Grenoble, que lecionou na Universidade de Ottawa, no Canadá e é atualmente professor no Departamento de Hipermídia da Universidade de Paris-VIII.
} 
Explicitando o termo 'virtual', Lévy (1999, p. 32) afirma que a virtualização é uma tendência fundamental e complementar à da universalização da Cibercultura - fusão de culturas nacionais em uma cultura globalizada e cibernética - que 'propaga a copresença e a interação de quaisquer pontos do espaço físico, social ou informacional". Para esse autor, a palavra 'virtual' pode ser entendida em pelo menos três sentidos: um filosófico, um corrente e um técnico, ligado à informática. (LEVY, 1999, p. 49)

Para Levy (1999, p. 49), no sentido filosófico, virtual é "aquilo que existe apenas em potência e não em ato", e tende a se resolver em uma atualização, como a árvore que está virtualmente presente no grão, mas precisa ser 'atualizada' para existir, já que o virtual se encontra antes da concretização efetiva. Filosoficamente, portanto, o virtual é uma dimensão da realidade, uma significação bem diferente daquela de uso mais corrente, em que se emprega o termo 'virtual' em oposição a 'real'. Em geral, considera-se que a realidade pressupõe uma realização material, enquanto a virtualidade seria sinônimo de irrealidade, o que acaba tornando contraditória a expressão 'realidade virtual', já que algo não deveria ser real e virtual ao mesmo tempo.

Lévy (1999) continua declarando que, para a filosofia, entretanto, a oposição não se dá entre 'virtual' e 'real', mas entre 'virtual' e 'atual', pois essas duas últimas condições são apenas duas diferentes formas de realidade. Recorrendo novamente à imagem da árvore, ele afirma que, se a virtualidade da árvore está presente no grão, então ela é bastante real, embora ainda não seja atual. Num sentido mais técnico, Lévy (1999, p. 49) define:

É virtual toda entidade "desterritorializada", capaz de gerar diversas manifestações concretas em diferentes momentos e locais determinados, sem contudo estar ela mesma presa a um lugar ou tempo em particular.

O autor argumenta que a palavra "árvore" pode ser considerada uma entidade virtual, pois existe sem estar presente. A enunciação desse elemento lexical seria sua 'atualização' e cada uma das atualizações seria diferente da outra, em termos acústicos ou semânticos, pois o virtual é uma fonte indefinida de atualizações. Uma das ligações da cibercultura com o virtual é direta, pois a digitalização da informação - os códigos de computador - é praticamente virtual, visto que é quase independente de coordenadas espaço-temporais determinadas. A informação se encontra fisicamente situada em algum lugar no centro das redes digitais, mas também está “virtualmente presente em cada ponto da rede onde seja pedida." (LÉVY, 1999, p. 50) 
Indiretamente, o desenvolvimento das redes digitais favorece outros movimentos de virtualização como a comunicação contínua, já que as particularidades técnicas do ciberespaço estimulam um estilo de relacionamento quase independente de espaços geográficos e coincidência temporal, permitindo que os membros de um grupo humano, sejam quantos forem, "se coordenem, cooperem, alimentem e consultem uma memória comum, e isto quase em tempo real, apesar da distribuição geográfica e da diferença de horários." (LÉVY, 1999, p. 51)

Pode-se afirmar, então, que os Ambientes Virtuais de Aprendizagem (AVA) são assim chamados por proporcionarem, a um grupo de participantes com o objetivo de ensinar e aprender, a possibilidade de interagir, cooperar e consultar um conjunto de informações constantes desses ambientes - e assim 'atualizá-las' - em tempo real, apesar de estarem em espaços geográficos e horários diferentes.

\subsubsection{Ambiente Virtual de Aprendizagem (AVA) - algumas possibilidades}

Paiva (2010), pesquisadora das áreas de Ensino/Aprendizagem de línguas estrangeiras e Linguagem e Tecnologia, e professora titular da Universidade Federal de Minas Gerais UFMG, apresenta algumas características dos Ambientes Virtuais de Aprendizagem, daqui em diante tratados por AVA, em estudo em que relaciona os conceitos de conhecimento e aprendizagem subjacentes à construção de AVAs à visão epistemológica ou 'mito' do experiencialismo, presente em Lakoff e Johnson (1980, p. 193), segundo o qual a produção do conhecimento é fruto do conjunto de nossas experiências.

Na visão experiencialista, segundo Paiva (2010, p. 355), o conhecimento, considerado dinâmico, em constante mudança, emerge das experiências em uma rede social colaborativa, em que a aprendizagem acontece em uma comunidade da qual o aprendiz se torna membro, o que vai ao encontro dos movimentos de virtualização já citados anteriormente (Lévy, 1999), que permitem estilos de relacionamentos participativos, pois coordenados, e cooperativos, apesar de desterritorializados e assíncronos, com o objetivo de, no caso dos AVAs, construir conhecimento.

Paiva (2010) assim comenta o surgimento dos AVAs:

Com o advento da internet, surgiram aplicações, na web, para gerenciamento de atividades educacionais guiadas pela metáfora da participação que podem 
contribuir para a aprendizagem colaborativa. Os ambientes virtuais de aprendizagem oferecem espaços virtuais ideais para que os alunos possam se reunir, compartilhar, colaborar e aprender juntos. Vale ressaltar que, no Brasil, esses ambientes virtuais, ou plataformas para educação on-line, ficaram consagrados com o nome de ambientes virtuais de aprendizagem (de agora em diante AVAs), mas, além desta, receberam nomes e siglas diferentes, em inglês, tais como ambientes integrados de aprendizagem (Integrated Distributed Learning Environments - IDLE); sistema de gerenciamento de aprendizagem (Learning Management System - LMS); e espaços virtuais de aprendizagem (Virtual Learning Spaces - VLE). (PAIVA, 2010, p. 357)

Ao descrever as características presentes em praticamente todos os aplicativos desses ambientes, Paiva (2010, p. 357) enumera:

- Uma interface gráfica.

- Ferramentas de comunicação assíncrona: fóruns, email, blog e mural.

- Ferramentas de comunicação síncrona: chat.

- Ferramentas de avaliação e construção coletiva: testes, trabalhos, wikis, glossários.

- Ferramentas de instrução: textos, atividades, livros, vídeos.

- Ferramentas de pesquisa de opinião: questionários, enquetes.

- Ferramentas de administração: perfil do aluno, cadastro, emissão de senha, criação de grupos, banco de dados, configurações, diários de classe, geração de controle de frequência e geração de relatórios, gráficos e estatísticas de participação.

A princípio, na década de 1990, quando os primeiros aplicativos para ambientes de aprendizagem foram desenvolvidos e comercializados, eles eram produtos caros, o que motivou grupos de pesquisadores a desenvolverem plataformas gratuitas, sempre organizadas em torno da metáfora da participação. No Brasil, foram criados o AulaNet e o TeleEduc, Eproinfo, o ROODA, o Eureka, o Virtus. No mundo inteiro, entretanto, os AVAs pagos sofrem a concorrência de um AVA gratuito, o Moodle (Modular Object-Oriented Dynamic Learning Environment), desenvolvido com o apoio de uma comunidade global. (PAIVA, 2010, p. 358)

O ambiente virtual que serviu de veículo à segunda aplicação da proposta de ensino de artigo científico aqui tratada é um ambiente Moodle ancorado na plataforma "Moodle USP do Stoa", definida na seção Sobre do próprio site em que ela está inserida 
(http://disciplinas.stoa.usp.br/) como "um ambiente virtual de aprendizagem em apoio às disciplinas da USP”.

Segundo informações constantes em estudo de Sabattini ${ }^{17}$, o Moodle, sigla referente a Modular Object-Oriented Dynamic Learning Environment, termo traduzido por: Ambiente Modular de Aprendizagem Dinâmica Orientada a Objetos, é uma plataforma de aprendizagem a distância baseada em software livre, que foi e continua sendo desenvolvida por uma comunidade mundial de programadores, formadores também de um grupo de apoio aos usuários. A fundação www.moodle.org apoia o desenvolvimento do software e sua tradução para vários idiomas, e a empresa www.moodle.com dá apoio profissional à sua instalação. $(2007$, p.1)

Sabattini (2007) explica que, como sistema de gestão de ensino e aprendizagem, o Moodle é "um aplicativo desenvolvido para ajudar os educadores a criar cursos on-line, ou suporte on-line a cursos presenciais, de alta qualidade e com muitos tipos de recursos disponíveis". Esse estudioso certifica que os cursos desenvolvidos no Moodle são criados num ambiente centrado no aluno e não no professor, pois esse aplicativo se baseia na filosofia do construcionismo, que prega que o conhecimento "é construído na mente do estudante, ao invés de ser transmitido sem mudanças a partir de livros, aulas expositivas ou outros recursos tradicionais de instrução". É por esse motivo que as ferramentas de interação entre os participantes de um curso inserido em plataforma Moodle merecem tanto destaque, pois sua filosofia pedagógica fortalece a noção de que o aprendizado ocorre particularmente bem em ambientes colaborativos. (SABATTINI, 2007, p. 2)

Outras iniciativas de criação de redes de aprendizagem podem ser citadas, como a Edmodo, que, de acordo com informações do site <www.edmodo.com> foi fundada por Nic Borg e Jeff O'Hara, em 2008, em Chicago, EUA, com o objetivo de "trazer a educação a um ambiente do século XXI" e em outubro de 2015 contava com 58.203.608 membros. Edmodo é definida como uma rede social mundial de aprendizagem que se dedica a conectar todos os aprendizes com as pessoas e recursos de que eles precisam para alcançar completamente seu potencial. A utilização é gratuita e inscrições podem ser feitas por professores e alunos para criar ou participar de grupos de estudo, em ambiente que utiliza a língua portuguesa.

O link <https://www.google.com/intl/pt-BR/edu/> (acesso em 26/02/2016) leva ao "Google for Education" - que se apresenta como um dispositivo educacional com 45 milhões

${ }^{17}$ Professor colaborador da Universidade Estadual de Campinas/UNICAMP e pesquisador do Instituto Edumed na área de Desenvolvimento de Tecnologias para Educação a Distância. 
de usuários em 190 países, inclusive no Brasil - em que são oferecidas ferramentas para "aprimorar a aprendizagem e a interação", ajudando professores e alunos a comunicarem-se e organizarem suas atividades escolares.

A apresentação de todos esses recursos online destinados ao campo da educação geralmente insiste em duas questões: favorecer a interação e aprimorar a comunicação entre alunos e professores participantes do processo educativo, visto que essas ações, essenciais na aprendizagem em sala de aula, são amplificadas por meio da tecnologia. Em vez de considerar que esses dois ambientes de ensino, o presencial e o virtual, apresentam características opostas, melhor dizer que elas são complementares e que, combinadas, podem beneficiar amplamente todo o processo educativo.

2.1.5. Características complementares da interação em ambientes presenciais e virtuais e alguns resultados

Parece-nos que um conceito com o qual muitos autores concordam é que os meios virtuais não devem apenas repetir as mesmas atividades das salas de aula presenciais, nem servir somente de meio para transmissão de informações em forma de textos a serem lidos. Essas novas formas de comunicação e interação devem ser conhecidas e exploradas de maneira a também se criarem atividades pedagógicas próprias para esses meios, as quais se beneficiem das características destes de maneira a tornar o processo de ensino mais envolvente, estimulando tanto o protagonismo dos sujeitos na construção de sua aprendizagem como a cooperação entre os participantes.

Partindo de estudos mencionados por Paiva (2001) e atualizados em trabalhos posteriores, como em Paiva e Rodrigues Jr (2004), pode-se dizer que as principais características interacionais da sala de aula presencial - participantes no mesmo espaço geográfico; sincronia; tempo limitado; participação linear - podem ser complementares às do ambiente virtual de aprendizagem - participantes geograficamente dispersos; assincronia; espaço temporal maior; participação não-linear. A autora afirma que a maior inovação dos ambientes virtuais é a flexibilidade de tempo e espaço, pois alunos e professores não precisam interagir em horários rígidos ou espaços predeterminados. (2001, p. 130)

Segundo Paiva (2001, p. 132), a interação no ambiente virtual pode ampliar as possibilidades de participação do aluno por ser menos inibidora, não havendo interrupção ou 
tomada abrupta de turno como na interação face a face. Por outro lado, as questões de ausência de suporte técnico por parte das instituições e dificuldades de acesso por parte dos alunos podem limitar a interação e, por consequência, a aprendizagem. Certamente, já vivemos uma época em que os avanços, seja por parte das instituições seja pela maior facilidade de acesso a computadores, tablets e até smartphones, vão minimizando problemas técnicos e permitindo usos mais integrados das tecnologias.

Haythornthwaite e Andrews (2011, p. 13), comparando as características da Comunicação Mediada por Computador (CMC) com aquelas das relações face a face, dizem que as primeiras observações são de que as mídias eletrônicas transmitem menos indícios comunicativos que as interações face a face. Eles citam o exemplo da lista de emails, que permite o envio de um texto por parte de um falante invisível para uma audiência também invisível, de tamanho e composição indeterminados, escondendo sinais visíveis de gênero, raça e idade. A princípio, parece um grande prejuízo, principalmente para quem perde status com essa invisibilidade, mas esse apagamento pode ter efeitos positivos para os mais tímidos, que deixam de contribuir ou participar por inibição.

Reflexos dessas constatações foram empiricamente observados durante as aplicações da proposta de ensino de artigo científico deste estudo, pois foram notados diferentes níveis de participação entre os alunos, conforme o meio em que as atividades eram desenvolvidas. Os participantes mais extrovertidos se destacavam na interação face a face, enquanto alguns mais inibidos na interação presencial só se manifestavam por meio de mensagens ou comentários via email ou deixados na plataforma virtual.

Haythornthwaite e Andrews (2011, p. 13) observam ainda que há diferentes possibilidades de comunicação tanto no ambiente presencial como no mediado por computador, cada uma com seu valor. Enquanto uma interação presencial em grupos pequenos permite a troca de inúmeras informações sobre o outro, a interação virtual permite o controle sobre que tipo de informação será transmitida à audiência, pois separa a mensagem de pistas sobre a identidade do falante, por exemplo, fortemente ligadas à interação face a face. Num contexto de aprendizagem, pode-se tirar proveito de ambas as situações, como afirmam os autores ao comentar as 'affordances'18 das duas situações de interação e suas indicações para desenvolver diferentes práticas educativas:

18 Termo ainda sem tradução consagrada para o português, "affordance" foi cunhado pelo psicólogo James J. Gibson referindo-se ao que um ambiente proporciona a um animal nesse contexto, uma ideia que foi adaptada para outras áreas como o design industrial - em que 'affordance' significa 
O anonimato - ou relativo anonimato possível quando faltam tantos indícios sobre um indivíduo é uma de um número de funcionalidades da comunicação mediada por computador (CMC). (...) destacando aquelas que diferem das funcionalidades da comunicação face a face. Estas incluem o anonimato, mas também a forma como a CMC proporciona a comunicação assíncrona (a qualquer tempo), móvel (em qualquer lugar) que potencialmente conecta largamente com outras pessoas (qualquer pessoa), tanto local como globalmente. Novas formas de captação de dados, como câmeras digitais, e de comunicação, como blogs e comentários em blogs, promovem rápida atualização e integração de informação. ${ }^{19}$ (HAYTHORNTHWAITE e ANDREWS, 2011, p. 14)

Esses autores indicam que as funcionalidades - termo que se vai adotar nesta pesquisa como tradução de "affordances" - tanto das tecnologias de comunicação mediada por computador quanto das interações face a face geram oportunidades para comunicar-se, aprender e criar entendimento e objetivos comuns, porém as condições são diferentes. Haythornthwaite e Andrews (2011, p. 14) creem que conhecer tais condições auxilia a planejar sua utilização e a identificar como cada característica das CMCs pode efetivamente beneficiar o processo educativo.

Esses estudiosos citam, por exemplo, a característica do anonimato, ou quase anonimato que permite aos participantes de uma interação online escolher que imagem de si mesmos desejam compartilhar. Numa situação de ensino, como é o caso de um curso ou disciplina cujo objetivo seja a produção do artigo científico, inicialmente, o quase anonimato é indicado como uma ótima maneira de incentivar a contribuição dos mais tímidos e dos que não estão familiarizados com as formas de interagir a distância, ou ainda os que estão preocupados com o julgamento alheio sobre sua performance. (HAYTHORNTHWAITE e ANDREWS, 2011, p. 16)

o potencial de um objeto de ser usado como foi projetado para ser usado - e a tecnologia computacional, entre outras. Quanto maior for a 'affordance' de um objeto, melhor será a identificação de seu uso. Talvez, para o contexto educacional, os termos "características funcionais" ou "funcionalidade" pudessem ser uma adaptação, pois se refeririam à potencialidade de cada característica dos ambientes presencias ou virtuais de serem utilizados mais eficientemente para determinada prática pedagógica. Optamos por 'funcionalidade'.

19 Tradução livre de: Anonymity - or the relative anonymity possible when so many cues about an individual are missing - is one of a number of affordances of CMC. (...) highlighting those that differ from the affordances of face-to-face communication. These include anonymity, but also the way CMC affords asynchronous (anytime), mobile (anywhere) communication that potentially connects widely to other people (anyone), both locally and globally. New forms of data capture, such as digital cameras, and of communication, such as blogs and blogs comments, afford rapid updating and aggregation of information. (HAYTHORNTHWAITE e ANDREWS, 2011, p. 14) 
A realização de uma atividade que 'apresente' os estudantes por meio da produção de um pequeno texto com ou sem foto vai iniciando, paulatinamente, a construção da identidade de cada aluno, pois, a médio e longo prazo, é desejável que o professor conheça os alunos e eles se conheçam entre si, para facilitar o processo de construção colaborativa de conhecimento. (cf. HAYTHORNTHWAITE e ANDREWS, 2011, p. 17)

A funcionalidade das características de assincronia, mobilidade e conectividade, segundo Haythornthwaite e Andrews (2011, p. 18), harmoniza-se bem com o nosso dia a dia agitado, nossas agendas cheias de compromissos profissionais, familiares e sociais, favorecendo o que hoje se chama de "ubiquitous learning" 20 , isto é, aprendizagem em qualquer lugar e a qualquer hora, intimamente associada a tecnologias móveis, pois os alunos podem acessar as plataformas dos cursos que realizam, de onde estiverem e quando desejarem, para executar as atividades propostas. De qualquer forma, essas características também podem fazer parte das aulas presenciais tradicionais, quando alunos realizam tarefas extraclasse em grupos via computador. Por outro lado, é possível realizar atividades síncronas como o chat ou as videoconferências. (cf. HAYTHORNTHWAITE e ANDREWS, 2011, p. 18)

Um efeito pouco positivo da assincronia no ensino mediado por computador é a demora entre postagem e resposta numa plataforma virtual de aprendizagem, diferentemente do imediatismo da interação face a face que, combinado com a expressão facial, a entonação e a linguagem corporal, permite feedbacks mais rápidos sobre ideias e dúvidas e maior elaboração na criação de entendimento comum. Mobilidade e conectividade intensificam a interação virtual, mas frequentemente é o 'social' que mais contribui - para melhor ou pior para criar um ambiente de aprendizagem mais participativo. (HAYTHORNTHWAITE e ANDREWS, 2011, p. 19)

O que se verificou nas ocasiões em que foi aplicada a proposta de ensino deste estudo é que atividades realizadas em ambientes mediados por computador - como a pesquisa para a escolha dos temas para a produção dos artigos e as tarefas de produção textual propriamente dita - tiveram um resultado bastante satisfatório em termos de participação e produtividade.

${ }^{20}$ Segundo YAHYA, AHMAD, e JALIL (2010, p. 119), uma definição abrangente de "ubiquitous learning", ou "u-learning" seria um modelo de aprendizagem que acontece em qualquer lugar e a qualquer tempo, referindo-se a ambientes que permitam qualquer dispositivo móvel acessar conteúdos de ensino e aprendizagem por meio de redes wireless. Os mesmos autores propõem uma atualização dessa definição para: "U-learning é um paradigma de aprendizagem que ocorre em um ambiente de computação ubíqua que permite aprender a coisa certa no lugar e no momento certos, da maneira certa." 
Crê-se que esse bom resultado esteja ligado às características de quase anonimato, assincronia, mobilidade e conexão constituintes dos ambientes virtuais de aprendizagem.

Outra observação que se faz relevante é que houve bastante cuidado, por parte do professor, com a linguagem escrita empregada nos enunciados que propunham as tarefas, nas mensagens aos alunos ou ainda nos comentários e revisões das suas produções textuais. Esse cuidado - que se traduziu no emprego de uma linguagem cortês e bem próxima da oral e coloquial, sem, contudo, distanciar-se da norma culta - teve o objetivo de estabelecer uma aproximação com os alunos participantes e foi positivamente decisiva na qualidade da participação e da responsividade dos cursos promovidos.

Sem dúvida, o emprego de uma linguagem mais próxima à dos estudantes também é decisivo para promover a interação presencial e a consequente construção colaborativa de conhecimento, fato registrado durante as duas aplicações da proposta de produção de artigo científico. Tal circunstância também vem ao encontro da observação de Haythornthwaite e Andrews (2011, p. 19), já mencionada anteriormente, de que a interação 'social' de qualidade, ou seja, dos seres humanos mais que da tecnologia, é que influenciará decisivamente a criação de um ambiente mais ou menos favorável à aprendizagem.

Esses autores ainda caracterizam a Comunicação Mediada por Computador (CMC) por sua persistência - que poderia também ser entendida como 'perenidade' - sua multimodalidade e o fato de ser em grande parte baseada em texto escrito. Em se tratando de relacionar tais características com sua funcionalidade no processo de ensino, Haythornthwaite e Andrews (2011, p. 22) afirmam que a persistência, ou melhor, a condição que as tecnologias mediadas por computador têm de armazenar conteúdos e mensagens para posterior recuperação, é uma forma de dar suporte à interação assíncrona possível nesses meios. Muito útil para a aprendizagem, essa condição de perenidade permite que textos postados, mensagens trocadas, tarefas, comentários e revisões feitas em tarefas por parte do professor sejam repetidamente acessados, revisitados, reutilizados e, em alguns casos, revistos.

No caso das aplicações desta proposta de ensino de texto acadêmico, coube ao professor responsável pela interação virtual via grupo de emails ou plataforma de aprendizagem definir quais atividades poderiam ser acessadas por todos os participantes como foi o caso dos fóruns de discussão e das postagens envolvendo conteúdo programático e textos de apoio - ou seriam tratadas de forma mais privada - como as mensagens individuais para os alunos, as tarefas e as revisões e comentários sobre as tarefas, feitos por parte do professor. Crê-se que a exposição em demasia de dados pessoais do aluno e de sua produção, 
tornando-os acessíveis a todos os participantes, pode criar questões delicadas, pois alguns poderiam considerar sua privacidade invadida.

Haythornthwaite e Andrews (2011, p. 16) também observam que, embora estejam surgindo novas tecnologias que permitem capturar, transmitir e integrar imagens, áudio e vídeo à linguagem verbal usada online - devido à característica de multimodalidade dos ambientes virtuais - principalmente nos ambientes de aprendizagem, uma grande parte da interação se dá por meio da linguagem escrita, uma circunstância bastante diferente dos estímulos orais e visuais da interação face a face na sala de aula presencial. Os autores comentam:

\begin{abstract}
A comunicação fortemente baseada em linguagem escrita representa uma grande transição dos estímulos orais e visuais de uma sala de aula ou de um cenário colocalizado. Faltam no texto escrito nuances de voz, tais como as variações deliberadas ou inconscientes no ritmo, no volume, no sotaque e no tom de voz; os gestos de mão, o olhar e a linguagem corporal; e pistas visuais de idade, vestimentas e raça. Não se consegue informação sobre a interação em grupo que pode ser adquirida a partir da disposição das carteiras e do posicionamento nas configurações grupo, ou por meio da observação de conversas paralelas e da atenção. (HAYTHORNTHWAITE E ANDREWS, 2001, p. 21) $)^{21}$
\end{abstract}

No presente estudo, também se observou que, nas atividades realizadas online, realmente predominam as formas verbais de linguagem, ou seja, o texto escrito, em atividades de leitura, troca de mensagens, elaboração de enunciados, explicações, tarefas, revisões, comentários, reescritas, etc. De qualquer maneira, se por um lado perdem-se muitas pistas que um ambiente presencial de aprendizagem pode fornecer, por outro a falta dessas pistas pode ser útil, permitindo que os participantes da interação virtual sejam julgados com base apenas no que eles escrevem, independentemente de outros aspectos. (HAYTHORNTHWAITE E ANDREWS, 2001, p. 21)

Embora esse tipo de comunicação menos pessoal seja desejável para o trabalho acadêmico, o que vem ao encontro da proposta deste estudo, Haythornthwaite e Andrews (2001, p. 21) advertem que um ambiente baseado apenas em texto pode se tornar improdutivo no sentido de promover conectividade interpessoal e senso de comunidade propícios à

${ }^{21}$ Tradução livre de: Our heavily text-based communication represents a major transition from the oral and visual stimulations of a classroom or co-located setting. Missing from text are nuances in voice such as deliberate or unconscious variation in vocal pitch, pace, volume, accent, etc.; handgestures, eye gaze and body language; and visual cues of age, dress and race. Gone is the information on in-group interaction that can be gleaned from seating arrangement and positioning in group settings, and observation of side-conversations and attention. 
construção colaborativa de conhecimento. Na tentativa de amenizar tal impessoalidade, esses estudiosos sugerem que é possível reintroduzir algumas marcas pessoais aos textos escritos por meio do uso de 'emoticons', da manifestação de emoções em mensagens e páginas de perfil ou uso comum de termos ou estilo associados ao contexto do curso, o que pode promover uma atitude mais cooperativa.

Além disso, esses autores afirmam que uma forma de enriquecer a interação via ambiente virtual num cenário de aprendizagem, evitando os inconvenientes de usar apenas a linguagem escrita, seria apelar ao caráter multimodal das interfaces de computação contemporâneas aliado à alta conectividade da banda larga. Uma consequência dessa aliança permitiria utilizar largamente, por exemplo, o hipertexto, contendo links que levam a figuras, ícones, menus, sites, etc. e promover novas formas não lineares de leitura. Desse modo, consegue-se alargar os limites do que pode ser feito no processo de aprendizagem virtual, iniciando uma probabilidade real de alcançar e engajar aprendizes nesse processo. (HAYTHORNTHWAITE e ANDREWS, 2011, p. 25)

Como novas formas de comunicação mediada por computador surgem num ritmo muito rápido, esses autores aconselham ao educador que fique atento para conhecer e procurar a utilidade e a funcionalidade de tais inovações tecnológicas no processo educativo. Nessa direção, o conjunto de atividades para o ensino de artigo científico no ensino superior de que se ocupa este estudo foi planejado e aplicado de forma a combinar atividades pedagógicas a serem desenvolvidas tanto em ambientes virtuais como em aulas presenciais, explorando as características de cada um em termos de interação, para proporcionar ao aluno de ensino superior uma experiência de aprendizagem relevante e envolvente, que o levasse à construção de conhecimento.

Essa integração de atividades presenciais e online se alinha às bases teóricas da Blended learning (aprendizagem combinada ou híbrida), propostas, entre outros por Horn e Staker (2015), Garrison e Vaughan (2008), Garrison (2011 [2003]), sobre a qual se falará um pouco a seguir.

2.1.5.1 Blended learning: combinação de atividades presenciais e virtuais na aprendizagem

Como não há ainda uma tradução consagrada ou de uso comum a outros pesquisadores brasileiros que estudam Blended learning, optou-se pela expressão Aprendizagem combinada, 
na tentativa de encontrar para o termo em inglês uma equivalência de sentido em língua portuguesa que se adaptasse aos objetivos da presente pesquisa. O termo ‘aprendizagem' - em vez de 'ensino' ou 'educação' - foi considerado mais representativo de 'learning', e o termo 'combinada' - em vez de 'mesclada', 'misturada' ou 'mista' - pareceu-nos mais adequado às características do presente estudo, pela possibilidade de envolver sentidos como 'acertada', 'ajustada', 'compatível', 'harmônica'.

De qualquer forma, é necessário notificar uma outra opção, como é o caso de Ensino Híbrido, tradução adotada pelos professores que compõem o Grupo de Experimentação em Ensino Híbrido, desenvolvido pelo Instituto Península e pela Fundação Lemann, e estudam "novas formas de atuação, planejamento e uso integrado das tecnologias digitais" na educação básica. No prefácio da obra ${ }^{22}$ que o grupo produziu sobre o tema, Ensino Híbrido é definido como "uma abordagem pedagógica que combina atividades presenciais e atividades realizadas por meio das tecnologias digitais de informação e comunicação (TDICs)." (BACICH, TANZI NETO, TREVISANI, 2015, p. 13)

Segundo a apresentação de Bacich, Tanzi Neto e Trevisani (2015, p. 23), organizadores da citada obra, no Ensino Híbrido, o professor organiza e direciona o processo de ensino planejando atividades que atendam às demandas reais da sala de aula, para que a aprendizagem "ocorra de forma colaborativa com foco no compartilhamento de experiências e na construção de conhecimento a partir das interações com o grupo," que podem acontecer via tecnologias digitais e nas discussões em sala de aula, utilizando materiais diversos.

O trabalho desse Grupo de Experimentação em Ensino Híbrido baseia-se nas ideias de Horn e Staker (2015) - em obra já traduzida para o português e revisada pelos próprios integrantes do citado grupo - segundo os quais a definição de Ensino Híbrido divide-se em três partes:

- Ensino híbrido é qualquer programa educacional formal no qual um estudante aprende, pelo menos em parte, por meio do ensino on-line, com algum elemento de controle do estudante sobre o tempo, o lugar, o caminho e/ou o ritmo.

- (...) o estudante aprende, pelo menos em parte, em um local físico supervisionado longe de casa.

- (...) as modalidades, ao longo do caminho de aprendizagem de cada estudante em um curso ou uma matéria, estão conectadas para fornecer uma experiência de aprendizagem integrada. (2015, p. 34)

\footnotetext{
22 Trata-se do livro Ensino Híbrido: Personalização e Tecnologia na Educação, organizado por Lilian Bacich, Adolfo Tanzi Neto e Fernando de Mello Trevisani, publicado em Porto Alegre, pela editora Penso em 2015.
} 
Mesmo a obra sendo pensada em relação à escola básica, seus fundamentos ajustam-se muito bem ao que a presente pesquisa propõe para o ensino de artigo científico no ensino superior: o aluno participa de um programa educacional formal - um curso ou uma disciplina com atividades presenciais e virtuais - e controla, especialmente na modalidade online, seu tempo, seu percurso no processo de aprendizagem; o estudante também participa do processo em um local físico, longe de casa, a sala de aula tradicional; e as modalidades/atividades são complementares, para que a experiência de aprendizagem seja integrada e, portanto, eficiente.

Para Moran (2015), autor de um capítulo da obra mencionada, é possível ensinar e aprender de muitas maneiras, a todo momento e em múltiplos espaços, com a mistura e a combinação de muitos ‘ingredientes’. Conforme o autor:

Híbrido significa misturado, mesclado, blended. A educação sempre foi misturada, híbrida, sempre combinou vários espaços, tempos, atividades, metodologias, públicos. Esse processo, agora, com a mobilidade e a conectividade, é muito mais perceptível, amplo e profundo: é um ecossistema mais aberto e criativo. (MORAN, 2015, p. 27)

Ao afirmar que, na educação, acontecem vários tipos de mistura, Moran (2015, p. 39) cita a combinação de saberes e valores, com a integração de várias áreas de conhecimento, de metodologias e de atividades de sala de aula presenciais com as digitais, no ambiente virtual. Para esse estudioso, em um mundo com tantas transformações como o nosso, as novas tecnologias facilitam a aprendizagem colaborativa, e a mescla entre sala de aula e ambientes virtuais é "fundamental para abrir a escola para o mundo e também trazer o mundo para dentro da instituição."

Em relação à influência que as novas tecnologias podem ter no ensino universitário, autores como Garrison e Vaughan (2008) falam especificamente sobre a necessidade de o ensino superior enfrentar a mudança de expectativas que a onda de inovações tecnológicas provoca em relação à qualidade das experiências de aprendizagem. $\mathrm{Na}$ apresentação de sua obra sobre a convergência entre a sala de aula e as tecnologias de educação com o objetivo de transformar a educação superior para melhor, os autores afirmam que os participantes do ensino universitário estão questionando a eficiência das abordagens tradicionais e reconhecendo a necessidade de examinar criticamente as atuais práticas de ensino e o potencial que as novas tecnologias de comunicação têm de proporcionar um envolvimento maior e contínuo no processo de aprendizagem. (GARRISON e VAUGHAN, 2008, p. ix)

Eles alegam que, quando os alunos estão ativamente empenhados, acontecem experiências de aprendizagem mais completas e significativas, e que os estudantes que 
cresceram em meio às tecnologias interativas nem sempre ficam à vontade com as clássicas aulas expositivas em formato de palestras. Entretanto, as abordagens que contemplam a aprendizagem combinada (blended learning) não consistem apenas de um aperfeiçoamento da aula presencial, elas propõem redesenhar completamente o ambiente educacional e a experiência de aprendizagem, acessando e integrando os pontos fortes do ensino presencial e a distância para atingir objetivos educacionais significativos, distinguindo entre os usos inovativos ou meramente substitutivos das TICs e preferindo os primeiros. (GARRISON e VAUGHAN, 2008, p. x)

Em obra de 2011 sobre aprendizagem virtual no século $\mathrm{XXI}^{23}$, Garrison retoma a descrição de Blended learning - que estamos traduzindo por Aprendizagem combinada - de obra citada anteriormente em parceria com Vaughan (2008), e afirma que, no ensino superior, a maior ocorrência de ensino mediado por computador acontece nos modelos de Aprendizagem combinada. $\mathrm{O}$ autor argumenta que é preciso procurar novas formas de integrar os alunos ao ensino universitário e que introduzir atividades realizadas em meios eletrônicos pode ter bons resultados. Ele diz:

O desafio de motivar os alunos no ensino superior requer novas ideias e abordagens. Simplesmente não é racional continuar a oferecer aulas expositivas e esperar que aumente a participação ativa dos alunos. A aprendizagem combinada tem potencial para alcançar os objetivos de pensamento e aprendizagem (do ensino) de nível superior. (GARRISON, 2011$, p. 75$)^{24}$

Defensor da eficiência das modalidades de aprendizagem em ambiente virtual, tradução adotada para e-learning ${ }^{25}$, Garrison define-as como "comunicações assíncronas e síncronas eletronicamente mediadas com o propósito de construir e confirmar

${ }^{23}$ Trata-se da obra: GARRISON, D. R. E-learning in the 21st century: A framework for research and practice. 2nd ed. Taylor \& Francis, Routledge: New York, 2011, uma segunda edição do mesmo título, revista e ampliada.

${ }^{24}$ Tradução livre de: The challenge of engaging learners in higher education requires new ideas and approaches. It simply is not rational to continue to offer passive lectures and hope to increase active student engagement. Blended learning has the potential to serve the goal of higher-order thinking and learning.

${ }^{25}$ Optou-se por traduzir "e-learning" como "aprendizagem em ambiente virtual", por considerar tal forma mais apropriada ao contexto desta pesquisa do que "educação a distância", termo abrangente e muito utilizado na literatura em língua portuguesa sobre o tema, mas que pode também nomear modalidades de ensino por correspondência, por rádio, etc. Garrison (2011, p. 3) considera a aprendizagem online um tipo de educação a distância que se diferencia de outras - cujas características principais seriam transmissão de conteúdo e aprendizagem independente - por sua origem e natureza interativa. 
conhecimento" ${ }^{26}$, cuja fundamentação tecnológica combina a internet e tecnologias de comunicação associadas. Segundo esse autor, as duas formas primárias de aplicação da aprendizagem em ambiente virtual são: totalmente online ou Aprendizagem combinada, sendo esta última a que prevalece em instituições mais tradicionais de ensino superior. (2011, p. 2)

Garrison (2011) afirma que, no contexto de uma sociedade de conhecimento que muda rapidamente, é fundamental aperfeiçoar as experiências de aprendizagem de forma que se preparem os alunos para experiências sociais e profissionais de caráter mais ativo e colaborativo. Nesse sentido, a aprendizagem virtual pode proporcionar uma experiência educacional de qualidade porque integra independência (comunicação virtual assíncrona) e interação que transcende limites de tempo e espaço (conectividade), o que vai ao encontro dos valores da educação superior. (GARRISON, 2011, p. 3)

Contudo, para que a aprendizagem em ambiente virtual seja completamente integrada ao conjunto de práticas do ensino universitário, não se pode minimizar ou desconsiderar o enorme valor da experiência educacional presencial. O poder de mesclar experiências online e face a face está no fato de que essa combinação reconhece e integra o enorme potencial da aprendizagem virtual enquanto respeita vantagens e preferências associadas a comunidades de aprendizagem presencial, no intuito de promover um discurso sustentado e rigoroso. (GARRISON, 2011, p. 3)

Comentando as vantagens dessa combinação de diferentes modalidades e citando obra em que tem Vaughan como coautor, Garrison (2011, p. 3) diz:

O potencial da aprendizagem em ambiente virtual de fundir discurso verbal e
escrito, sem restrição de tempo, levou educadores a repensar as
possibilidades de engajar estudantes universitários em ambientes face a face
e online. Esta combinação bem planejada de abordagens presenciais e
virtuais complementares para atingir objetivos educacionais específicos tem
sido chamada de aprendizagem combinada (Garison \& Vaughan, 2008). A
aprendizagem virtual sob a forma de aprendizagem combinada integra as
melhores características de educação online e face a face. $(2011, \text { p. } 3)^{27}$

26 Tradução livre e adaptada de: E-learning is formally defined as electronically mediated asynchronous and synchronous communication for the purpose of constructing and confirming knowledge. Garrison (2011, p. 2)

${ }^{27}$ Tradução livre de: The potential of e-learning to merge verbal and written discourse, unconstrained by time, has caused educators to rethink the possibilities for engaging campus-based students in faceto-face and online environments. This thoughtful blending of complementary face-to-face and online approaches to meet specific educational goals has been termed blended learning (Garison \& Vaughan, 2008). E-learning in the form of blended learning integrates the best features of online and face-to-face education. (GARRISON, 2011, p. 3) 
Enfim, para Garrison (2011, p. 75), basicamente o que descreve um modelo de aprendizagem combinada é a completa integração de atividades presenciais e online, de modo que os pontos fortes de cada experiência educacional se fundam para que os resultados sejam melhores do que o melhor dos elementos constituintes sozinhos. Por essa razão, o autor retoma Garison e Vaughan (2008, p. 148) para afirmar que uma definição de aprendizagem combinada também poderia ser "a integração orgânica de abordagens e tecnologias presenciais e online, cuidadosamente selecionadas e complementares". ${ }^{28}$

A aprendizagem por meio de ambientes virtuais auxilia a construção de coesão e de sentido de grupo entre os participantes de uma comunidade de aprendizagem presencial, pois encoraja maior, ou mais variada, participação. A comunicação escrita assíncrona, que pode ocorrer em fóruns e mensagens trocadas, além de reflexiva - pois não precisa ser imediata -, permite ao participante animar-se a correr riscos intelectuais ao expor seus posicionamentos, pois o julgamento alheio, quase que instantâneo na interação presencial, está mais distante na interação virtual. (GARRISON, 2011, p. 78)

Comentando as consequências dessa comunicação mais facilitada, o autor afirma:

Esta liberdade de expressão, então, influencia positivamente a interação face a face, já que os alunos se sentem mais à vontade para participar. De uma forma antiintuitiva, a aprendizagem online permite que os participantes se revelem de maneiras que talvez não o fizessem em um ambiente face a face. Eles se sentem menos intimidados pela presença imediata de outros no grupo. As oportunidades para atividades em pequenos grupos podem aumentar, e há mais tempo para construir relações, pois a comunicação é estendida para além da sala de aula presencial. (GARRISON, 2011, p. 78 ) $^{29}$

Entretanto, Garrison (2011, p. 76) adverte que a aprendizagem combinada não consiste apenas em acrescentar atividades online às práticas presenciais de sala de aula. A proposta é repensar e redesenhar a abordagem educacional com o propósito de planejar atividades coerentes que substituam uma audiência passiva por atividades colaborativas e reflexivas para incrementar a interação. Se há aulas expositivas, elas devem propiciar aos participantes a oportunidade de se reunirem posteriormente e interagirem em pequenos grupos para

${ }^{28}$ Tradução livre de: (...) the organic integration of thoughtfully selected and complementary face-toface and online approaches and technologies. (GARRISON, 2011, p. 75)

${ }^{29}$ Tradução livre de: This freedom of expression then enhances the face-to-face session as students feel more comfortable to participate. In a counter-intuitive manner, online learning allows participants to reveal themselves in ways they might not in a face-to-face environment. They are less intimidated by the immediate presence of others in the group. There may also be increased opportunity for small group activities, and relationships have more time to build as communication is extended beyond the face-to-face classroom. (GARRISON, 2011, p. 78) 
questionar os conteúdos propostos e relatar suas considerações, individualmente ou através de um porta-voz.

Garrison (2011, p. 77) cita como exemplo aulas de produção textual, que podem, ao combinar atividades presenciais e online, focar no processo de escrever, aplicando o conhecimento adquirido na prática propriamente dita. Estamos em concordância com Garrison ao desenvolver, no ensino de artigo científico, atividades práticas que têm como foco o processo de escrever, bem como o de reescrever, após os comentários do professor. Entendemos que aprender a produzir um texto implica prática de escrita que, no caso da proposta desta pesquisa, pode ocorrer seja por meio de tarefas presenciais em grupo propostas após aulas expositivas, seja por atividades individuais de produção textual das diversas seções do artigo científico a serem entregues e revistas via ambiente virtual. Tais procedimentos estão expostos mais detalhadamente no Capítulo 4, que apresenta o conjunto de atividades realizadas para o ensino de produção textual de artigo científico.

Assumimos, como Garrison (2011), a importância de adotar uma posição flexível que escolhe fugir de modelos rígidos, e reconhece que não há regras infalíveis para conceber experiências bem-sucedidas de aprendizagem combinada. É preciso considerar as complexidades contextuais de cada curso ou disciplina e as diferentes características comunicativas do grupo de participantes. Além do mais, qualquer experiência de ensino demanda o empenho e o comprometimento de um professor experiente e bem-informado, mas também intuitivo, que consiga adaptar princípios e diretrizes a contingências e exigências de seu contexto de ensino único. (GARRISON, 2011, p. 5)

Uma grande parte do desafio da adoção da aprendizagem combinada nas instituições educacionais tradicionais, segundo Garrison (2011, p. 82), está relacionada à resistência à mudança, mas o autor assegura que as experiências já realizadas confirmam que combinar atividades presenciais e virtuais no ensino tem impacto bastante positivo na interação do aluno com o ensino superior. Segundo esse estudioso, tais experiências podem construir credibilidade para todas as modalidades de ensino online.

Em nosso país, relatos em eventos que tratam da adoção das novas tecnologias mediadas por computador e das práticas educacionais a distância abordam a questão de que essa modalidade de ensino foi um pouco desacreditada no Brasil, pois a princípio foi adotada por algumas instituições como uma forma de baratear os custos de cursos oferecidos. Os atuais estudiosos do tema, entretanto, estão pesquisando como as modalidades de aprendizagem mediadas pelas novas tecnologias podem ter a qualidade de que a universidade 
precisa, seja em cursos totalmente a distância ou naqueles em que se desenvolvem atividades tanto em aulas presenciais como online, como é o caso deste estudo.

Alguns outros pontos em que esta pesquisa está em concordância com Garrison (2011, p. 83) são referentes às diretrizes sobre as práticas propriamente ditas, quando esse autor afirma que um ensino efetivo requer mais do que um repertório de técnicas, pois é preciso que haja uma perspectiva coerente sobre a interação das dimensões colaborativa (social) e construtivista (cognitiva) do processo de ensinar e aprender. Além disso, Garrison ainda acrescenta que, mesmo quando o discurso e as atividades são preferencialmente realizados pelos alunos, o papel daquele que ele chama de 'instrutor' ou 'facilitador' é protagonista, por gerir e monitorar a experiência de aprendizagem, seja ela realizada em salas presenciais seja em ambientes virtuais.

Tais conceitos, denominados presença cognitiva, presença social e presença de ensino, fazem parte do modelo teórico da Comunidade de Inquirição - tradução de Community of Inquiry - proposto por Garrison, Anderson e Archer (2000) e retomado em Garrison (2011) - constituindo abordagem que converge uma perspectiva construtivista da aprendizagem online, baseada na interação e no trabalho colaborativo, e a busca de qualidade e rigor no ensino superior. ${ }^{30}$

O autor considera 'presença' uma identidade criada através de comunicação interpessoal e retoma obras anteriores suas e em coautoria para definir: 1) presença cognitiva como "a medida em que os estudantes constroem e confirmam significados por meio de reflexão e discurso críticos numa comunidade de aprendizagem" (GARRISON, ANDERSON e ARCHER, 2001); 2) presença social como "habilidade dos participantes de se identificarem com um grupo e se comunicarem objetivamente num ambiente de confiança, desenvolvendo relações afetivas e pessoais de modo a projetar suas personalidades individuais" (GARRISON, 2009) ; e 3) presença de ensino como "o planejamento, a facilitação e a direção dos processos cognitivos e sociais, com o objetivo de obter resultados pessoalmente significativos e educacionalmente válidos" (ANDERSON, ROURKE, GARRISON, e ARCHER, 2001). A presença de ensino, exercida pelo professor, estabelece entre os elementos da comunidade de aprendizagem uma relação equilibrada, funcional e coerente com os resultados desejados e as necessidades e capacidades dos alunos.

\footnotetext{
${ }^{30}$ Traduções para a língua portuguesa encontradas em: MOTA, J. C., Da Web 2.0 ao e-Learning 2.0: Aprender na Rede. Dissertação (Mestrado em Pedagogia do e-learning), Universidade Aberta, 2009.
} 
Garrison (2011, p. 83) ainda detalha como cada atividade que envolva as atividades de ouvir, falar, ler e escrever pode ser organizada e entendida sob as perspectivas cognitiva, social e de ensino, estabelecendo uma discussão pragmática bastante interessante sobre a experiência de aprendizagem online. Apesar de se considerarem bastante válidas tais diretrizes metodológicas, no presente estudo deu-se preferência a utilizar as Sequências Didáticas de Dolz, Noverraz e Schneuwlly (2004, p. 82) como procedimento, por sua flexibilidade e adaptabilidade ao ensino de gêneros textuais, conforme se explicitará no Capítulo 3.

Tratados os aspectos interativos envolvidos na aprendizagem, embora saiba-se que o tema não se esgota completamente por sua complexidade e pela quantidade de autores que se dedicam a estudá-lo, passamos a seguir a examinar mais detidamente os aspectos cognitivos que foram levados em consideração na proposta de ensino de artigo científico para a graduação.

\subsection{Enfoque cognitivo}

Para se analisar mais profundamente o processo de ensinar e aprender, particularizado neste estudo pelo ensino de produção do artigo científico no ensino superior, optou-se por, além de se observarem os aspectos por assim dizer externos ou situacionais da interação que ocorre durante tal processo - como foi feito anteriormente - também conhecer os atuais estudos sobre enfoques cognitivos que envolvem a construção de sentido e de conhecimento em geral, nas situações de ensino e aprendizagem e, mais especificamente, no ensino que envolve produção textual em língua portuguesa.

Em oposição à exterioridade da interação, da troca com o outro, para este trabalho, resolvemos nomear os enfoques cognitivos como internos ou mentais da aprendizagem, visto que o que se deseja observar, segundo alguns autores que pesquisam a cognição (Lakoff, 1987; Lakoff \& Johnson 1980, Langacker, 1987, 1990, 1991; Talmy, 1983, 1988; Silva, 1997 , 2001, 2004, 2007; Fauconnier e Turner, 2002, 2008; Coscarelli, 2005; Militão, 2009), são as construções mentais que ocorrem quando um indivíduo fala ou pensa, ou seja, a maneira como se dá mentalmente a construção de sentido.

De qualquer maneira, uma circunstância comum, seja da interação, seja da construção de sentido, é que ambas se dão por meio da linguagem. No âmbito desta pesquisa, 
consideramos a língua portuguesa como intermediadora tanto da interação, como da construção de conhecimento no ensino de produção de texto acadêmico.

Embora nossa proposta de ensinar o artigo científico vise, em princípio, ao desenvolvimento de competências para produção textual de tal gênero, o fato de propor que esse ensino aconteça em forma de disciplina obrigatória ou optativa do curso superior em que se insere e que se utilize a língua portuguesa também procura promover a integração entre a atividade de produção linguístico-textual e a aquisição do conhecimento específico, por proporcionar uma participação mais ativa e crítica dos estudantes em seu processo de aprendizagem. Consideramos que, quanto maior a competência linguística - e a aprendizagem de produção textual promove a aquisição de tal competência - mais conexões mentais para a construção de sentido são estabelecidas, favorecendo tanto a construção de conhecimento linguístico como de saberes específicos, numa relação dialógica.

Decidimos, portanto, para examinar os citados processos de construção de sentido e conhecimento, tomar por base os princípios da Linguística Cognitiva, que, segundo Silva (1997, 2001, 2004, 2007), constituiu-se institucionalmente com a criação da International Cognitive Linguistics Association em 1989, mas nasceu e se desenvolveu nos anos 80, principalmente graças aos trabalhos dos americanos George Lakoff (1987 e Lakoff \& Johnson 1980), Ronald Langacker (1987, 1990, 1991) e Leonard Talmy (1983, 1988).

Silva (2004, p. 2) considera como um dos pressupostos da Linguística Cognitiva (LC) ser a interação com o mundo mediada por estruturas como a linguagem - cuja função básica é a categorização - tomada como meio de interpretar e construir tal mundo, de organizar conhecimentos que refletem as necessidades, os interesses e as experiências dos indivíduos e das culturas. Ao comentar a consolidação teórica da LC, refletida no pluralismo de teorias, em particular na vasta tradição funcionalista, oposta à formalista, Silva afirma:

Também estas perspectivas funcionalistas, mais umas do que outras, partilham da ideia fundamental da Linguística Cognitiva: a de que a linguagem é parte integrante da cognição (e não um "módulo" separado), se fundamenta em processos cognitivos, sócio-interaccionais e culturais e deve ser estudada no seu uso e no contexto da conceptualização, da categorização, do processamento mental, da interacção e da experiência individual, social e cultural. (SILVA, 2004, p. 2)

Num trabalho posterior, em que apresenta uma descrição dos estudos linguísticos sobre as variedades europeia e brasileira do idioma português, Silva (2007, p. 190) afirma que a LC assume que "toda a linguagem é acerca do significado e o significado é perspectivista" 
(grifos do autor), o que equivale a dizer que não reflete objetivamente o mundo, mas o constrói sob determinada perspectiva. Além disso, por assumir que a linguagem serve para caracterizar o mundo, o significado linguístico pode ser enciclopédico, ligado ao conhecimento de mundo e, dessa maneira, associado a outras capacidades cognitivas; flexível, pois adapta-se às mudanças e circunstâncias; e baseado na experiência (individual, biológica, coletiva, social, cultural) e no uso atual que fazemos da língua. (SILVA, 2007, p. 190)

Silva (2007, p. 191) cita, entre as principais linhas investigativas da Linguística Cognitiva (LC), a Teoria da Metáfora Conceptual (Lakoff \& Johnson, 1980, 1999, Lakoff, 1993, Kovecses, 2002), que gira em torno da afirmação de que "nosso sistema conceptual ordinário, em termos do qual não só pensamos, mas também agimos, é fundamentalmente metafórico por natureza" e do conceito de metáfora conceptual, que estrutura atividades cotidianas e envolve a compreensão de um domínio da experiência em termos de um domínio diferente de experiência. Esses autores também acreditavam que observar a linguagem é um meio de descobrir como funciona nosso sistema conceitual, algo de que normalmente não temos consciência, mas que estrutura nossos pensamentos, atitudes e relações com o outro, incluindo nossa comunicação linguística. (LAKOFF \& JOHNSON, 1980, p. 3)

Entre os estudiosos também citados por Silva (2007, p. 191), encontram-se os criadores da Teoria dos Espaços Mentais (Fauconnier 1985, 1997) e da Teoria da Integração (ou Mesclagem) Conceptual, "Blending Theory”, (Fauconnier e Turner, 2002), esta última caracterizada como complementar da Teoria da Metáfora Conceptual e de grande alcance no discurso e na gramática, pois busca, por meio da linguagem, examinar o que acontece nos bastidores da cognição, observando as associações entre domínio-alvo e domínio-fonte dos estudos metafóricos, considerando o contexto situacional particular. (FAUCONNIER E TURNER, 2002)

Por também acreditarmos que as investigações acerca de questões textuais-discursivas necessitem levar em consideração a linguagem, o jogo interacional nos processos cognitivos e a sociedade, passamos a seguir a uma observação mais detalhada das Teorias dos Espaços Mentais e da Mesclagem Conceptual (Fauconnier 1985, 1997, Fauconnier e Turner, 2002).

2.2.1 Teoria dos Espaços Mentais e Teoria da Mesclagem Conceptual (TMC) 
Fauconnier e Turner (2002, prefácio) registram que, aproximadamente cinquenta mil anos atrás, no Período Paleolítico Superior, nossos ancestrais experimentaram um avanço espetacular na história da humanidade, começando a exercer uma capacidade de inovar sem precedentes, ao desenvolver arte, ciência, religião, cultura, ferramentas sofisticadas e linguagem. Segundo esses autores, pode ter sido a capacidade mental de fazer integrações ou mesclagens conceituais de forma avançada, da qual temos pouca consciência, que levou a esse avanço e nos tornou o que somos hoje.

Em entrevista concedida a Coscarelli (2005, p. 291) em abril de 2004, na Universidade da Califórnia, Fauconnier explica como a Teoria dos Espaços Mentais, "pequenos conjuntos de memória de trabalho que construímos enquanto pensamos e falamos", trata dos processos mentais que não podemos ver ou ouvir, mas acontecem nos bastidores da cognição. Fauconnier coloca:

Espaços mentais se referem ao que acontece por detrás das cenas quando
falamos ou pensamos; são construções mentais muito complexas, até mesmo
para as sentenças mais corriqueiras. São pequenos conjuntos de memória de
trabalho que construímos enquanto pensamos e falamos. Nós conectamos
esses espaços entre si e também os relacionamos a conhecimentos mais
estáveis. (COSCARELLI, 2005, p. 291)

Para Fauconnier, definir espaço mental abstratamente, sem exemplos e um contexto mais completo não é fácil. Como ninguém pode ver os espaços mentais no cérebro, as definições ficam no campo da probabilidade: é provável que os espaços mentais sejam ativações estabelecidas no cérebro, na memória de trabalho, e sejam organizados e conectados por meio de "excitações sincrônicas de conjuntos de neurônios". Tal definição é um tipo de descrição baseada em generalizações que permitem explicar ou formular hipóteses sobre a linguagem, o pensamento. Para o autor, "evidências para essas atividades mentais implícitas e para as conexões dos espaços mentais são fornecidas através de conhecimentos linguísticos e gramaticais." (cf. COSCARELLI, 2005, p. 291)

Referindo-se à ligação entre os modelos mentais e a posterior e complementar Teoria da Mesclagem Conceitual (TMC), desenvolvida em obra de 2002 escrita conjuntamente com Turner, Fauconnier comenta:

Nós chamamos a atenção no livro The Way We Think para uma operação cognitiva fundamental para os seres humanos: a capacidade de agrupar diversos espaços mentais e, a partir desse agrupamento, criar novos espaços mentais que possuem uma estrutura emergente. Os seres humanos, em particular, parecem capazes do que chamamos de "integrações de duplo escopo", em que espaços mentais conflitantes são introduzidos. A partir dessa integração de espaços podem surgir novas estruturas muito criativas. 
Argumentamos indiretamente que essa capacidade de fazer mesclas duplas pode, de fato, ser o que caracteriza as capacidades cognitivas de nossa espécie. É ela que nos permite fazer coisas tais como arte, ferramentas, ciência e linguagem, habilidades que outras espécies não parecem possuir. (COSCARELLI, 2005, p. 292)

Tais habilidades podem ser consideradas relativamente recentes na evolução da espécie humana, tendo surgido de cinquenta a setenta mil anos atrás e, por parecer que tenham surgido ao mesmo tempo, os autores especulam que elas podem estar relacionadas à capacidade de fazer integrações conceituais de escopo duplo. Trata-se de importante atividade cognitiva mediada pelo pensamento e pela linguagem que, além de estabelecerem, conectarem e transferirem espaços mentais, projetam estruturas de uns para outros e criam novos espaços mentais à medida que se avança no processo cognitivo. (COSCARELLI, 2005, p. 294)

Fauconnier (1977, p. 149) explica que a mesclagem é, a princípio, uma operação simples que, na prática, dá origem a muitas possibilidades. Ela opera com dois espaços mentais de entrada (inputs) para produzir um terceiro espaço, a mesclagem (blend). A mesclagem herda estrutura parcial dos espaços de entrada e tem uma estrutura emergente própria. ${ }^{31}$ Em Fauconnier e Turner (2002, p. 40), temos que os espaços mentais estão ligados ao conhecimento esquemático de longo prazo chamado "frame", como o frame de andar por um caminho, e ao conhecimento específico de longo prazo, tal como "uma memória da época em que você escalou o Monte Rainier, em 2001"32.

Também em Fauconnier e Turner (2002, p. 45), encontramos uma representação do diagrama básico da integração conceitual na Teoria da Mesclagem, segundo os próprios autores, apenas um 'instantâneo' de um complicado processo imaginativo, pois uma mesclagem pode servir de entrada a outras mesclagens, formando conexões em uma rede integrada. A figura vem reproduzida a seguir:

31 Tradução livre de: Blending is in principle a simple operation, but in practice gives rise to myriad possibilities. It operates on two Input mental spaces to yield a third space, the blend. The blend inherits partial structure from the input spaces and has emergent structure of its own. (FAUCONNIER, 1977, p. 149)

32 Tradução livre de: Mental spaces are connected to long-term schematic knowledge called "frames', such as the frame of walking along a path, and to long-term specific knowledge, such as a memory of the time you climbed Mount Rainier in 2001. (FAUCONNIER e TURNER, 2002, p. 40) 


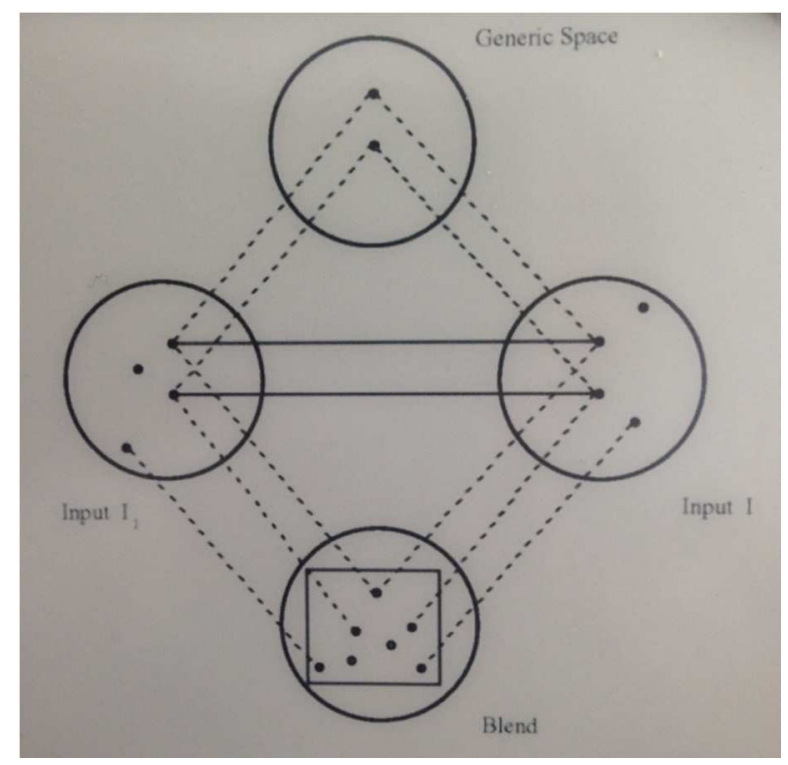

Figura 1: Diagrama básico do processo de mesclagem (FAUCONNIER e TURNER, 2002, p. 45)

Para Fauconnier e Turner (2002, p. 45), os círculos representam os espaços mentais (espaço genérico/Generic space, espaços de entrada/Inputs 1 e 2 e espaço de mesclagem/Blend ${ }^{33}$ ); as linhas contínuas assinalam a correspondência e o mapeamento transversal entre as entradas (inputs 1 e 2); e as linhas pontilhadas indicam conexões entre as entradas, o espaço genérico e o espaço de mesclagem. $\mathrm{O}$ quadrado inserido no espaço de mesclagem representa a estrutura emergente. ${ }^{34}$ Os autores consideram as linhas que representam projeções e mapeamentos conceituais como correspondentes a ligações e coativações neurais. (FAUCONNIER e TURNER, 2002, p. 46)

Frequentemente, as mesclas são construídas usando linguagem. Se as palavras surgem nas entradas (inputs), elas podem ser projetadas como qualquer outro elemento, e o resultado do processo pode mudar seu domínio de aplicação, quando o significado emergente parecer distante do domínio de origem. Para Fauconnier e Turner (2002, p. 142), a razão de a linguagem levar a mesclagens que resultam na mesma palavra ser usada com sentidos diferentes, o fenômeno comum da polissemia, é que a linguagem não representa o sentido diretamente; ao contrário, ela leva à construção de sentido, pois o mundo do significado

${ }^{33}$ Para Feltes (2009, p.156), os espaços de mesclas "substituem, de certo modo, as expressões 'domínio-fonte' e 'domínio-alvo' no modelo bidimensional proposto por Lakoff e Johnson (1980) e Lakoff (1987)".

34 Tradução adaptada de: The circles represent mental spaces, the solid lines indicate the matching and cross-space mapping between the inputs, the dotted lines indicate connections between inputs and either generic or blended spaces, and the solid square in the blended space represents emergent structure. (FAUCONNIER e TURNER, 2002, p. 45) 
humano é muito mais rico do que as formas linguísticas. Esses autores afirmam que a operação cognitiva da mesclagem conceitual não está restrita à linguagem, mas uma mente capaz dessa operação e que também conhece linguagem vai inevitavelmente desenvolver sentidos para palavras por meio de mesclagens. (FAUCONNIER e TURNER, 2002, p. 142)

Em entrevista concedida a Coscarelli (2005, p. 296), Fauconnier complementa essa questão dizendo que a linguagem "nos dá pistas sobre como construir significados quando nos encontramos em determinado contexto, em determinadas situações", para isso usamos nossas capacidades cognitivas, mas também buscamos muitas informações sobre o contexto e a situação, utilizando âncoras materiais que captamos de pessoas, falantes, ouvintes, objetos. Estabelecendo uma relação entre as teorias dos espaços mentais e da enunciação, o autor afirma que há nelas um embasamento comum de não ver a linguagem como forma estática e de considerar a dinâmica das situações comunicacional e enunciativa, às quais nos adaptamos à medida que o discurso se desdobra.

Militão (2009, p. 306) diz que a TMC pode oferecer subsídios para pesquisas a respeito do texto e do discurso, por tentar explicar as atividades cognitivas humanas sem dissociá-las daquelas de natureza linguística. Além disso, essa teoria sustenta que a cognição humana é dependente do contexto e examina quais conexões nossas mentes tendem a fazer e que efeitos são produzidos em diferentes contextos por meio da linguagem em uso, possibilitando descrever como o ser humano reconstrói significados. Militão afirma:

(...) ser a Teoria da Mesclagem Conceitual uma boa proposta para se analisar o processamento de textos, seja ele por via da leitura ou da escrita. Isso porque ela leva em consideração aspectos interacionais e sociocomunicativos no desenho do mapeamento conceitual que os sujeitos fazem ao executar essas tarefas. (MILITÃO, 2009, p. 304)

Com respeito à produção textual, Militão (2009, p. 314) considera importante conhecer o processo de mesclagem para analisar textos completos, uma vez que tal conhecimento nos leva a pensar em uma relação em rede entre os espaços, tal como se faz recursivamente na construção de um processo de referenciação. Entretanto, ela adverte que só conseguimos mesclar aquilo que compreendemos e só o fazemos através de relações vitais como causa/efeito, parte/todo, tempo, identidade, etc. A autora parte do pressuposto de que, no trabalho com a linguagem, o ser humano "comprime o que é difuso para compreender, e o faz por meio de uma série de mesclagens entre construtos mentais que constrói enquanto fala e ouve, ou enquanto escreve e lê." (MILITÃO, 2009, p. 315) 
Para exemplificar a utilização desse conhecimento numa situação de ensino, Militão (2009, p. 315) apresenta uma aula em que o aluno escuta e registra a exposição do professor e precisa recuperar essa informação em uma atividade de produção de texto. Segundo a autora, as chances de fazer adequadamente a seleção e a articulação das informações serão maiores se o aluno conhecer previamente os objetivos do professor ao trabalhar a referida atividade. Utilizando os termos da TMC, não há "como saber, naturalmente, o que será útil no futuro, mas, se soubermos que teremos que fazer determinadas mesclas, faremos com mais facilidade a identificação de "inputs" e conexões úteis durante o processo de leitura." Por esse motivo, o professor deve redobrar a atenção ao selecionar conteúdos e significados que pretende abordar em relação a seu objeto de estudo/trabalho, além de esclarecer quais são seus objetivos em relação às atividades propostas. (MILITÃO, 2009, p. 315)

Estamos em consonância com Militão, ao afirmarmos que, por considerar os processos cognitivos sem desconsiderar a linguagem e os contextos situacional e social, a Teoria da Mesclagem pode ser qualificada como uma abordagem integrada dos processos cognitivos, que entende a compreensão e o sentido como algo em contínua construção por ocasião do processamento discursivo e interacional. Bem próxima a essa postura está o termo cognição contingenciada (grifo nosso), cunhado por Marcuschi (2007, p. 19), como forma de cognição "que se dá diretamente na elaboração mental vinculada a situações concretas colaborativamente trabalhadas na interação contextualizada". Para esse autor, a expressão contingenciada dá conta da vinculação situacional, em que o efeito de sentido "é o produto de operações cognitivas, linguísticas e discursivas realizadas colaborativamente", portanto, não é um dado inscrito num texto, mas fruto direto da construção colaborativa e situada.

Parece ainda adequado a esta pesquisa sobre o ensino de artigo científico, que considera relevante examinar como se dá a interação em ambientes presenciais e virtuais, além de estudar a cognição vinculada ao ensino de produção textual que adota uma perspectiva linguística sociointerativa, tomar o gênero como instrumento didático, pelas implicações discursivas, interativas e sociais que tal opção encerra. Apresentamos a seguir um exame mais detalhado da questão do ensino de produção textual por meio do gênero. 


\section{CAPÍTULO 3}

A teoria dos gêneros

- uma opção para o

ensino de produção

textual 
Neste capítulo, tratamos da opção por construir nossa proposta de ensino de artigo científico tomando por base a teoria dos gêneros, conforme a perspectiva de autores como Marcuschi (2008), Lopes-Rossi (2011), Motta-Roth (2011). Recuperamos ainda os conceitos de macro, micro e superestruturas na análise e organização de textos, desenvolvidos por Van Dijk (1980) e a abordagem pedagógica da produção de escrita acadêmica proposta por Castelló e Iñesta (2012).

Examinaremos também a proposta de Swales (1990), atualizada em Swales e Feak (1994, 2004, 2012), de 'movimentos retóricos' para a elaboração do artigo científico em Língua Inglesa e a adaptação dessa teoria feita por Motta-Roth e Hendges (2010) para sua produção em Língua Portuguesa. Apresentamos, então, a concepção do gênero artigo científico com a qual trabalhamos durante as aplicações desta proposta e nossa opção em fazê-lo por meio de Sequências Didáticas, um conjunto de atividades organizadas em torno de um gênero textual-discursivo para ensiná-lo, segundo Dolz, Noverraz e Schneuwly (2004).

\section{1 A questão do gênero textual-discursivo}

A proposta de ensino de produção textual a que visa este trabalho constitui-se de um conjunto de atividades didáticas organizadas de maneira sistemática, para serem desenvolvidas parte em aulas presenciais e parte em ambiente virtual, tendo em vista o gênero textual-discursivo artigo científico. Nessa direção, consideramos relevante observar a posição de alguns estudiosos da questão do gênero textual-discursivo, nosso objeto de pesquisa. Nossa opção por tomar o gênero como instrumento didático alinha-se, entre outras, à posição de Marcuschi (2008, p. 208), que, por sua vez, retoma a visão de Bakhtin ([1979]1997) sobre os gêneros textuais como "esquemas de compreensão e facilitação da ação comunicativa interpessoal", por considerarmos que um dos propósitos de ensinar produção de escrita acadêmica é preparar o aluno de ensino superior para a prática social de se expressar mais adequadamente na situação comunicativa de registrar e transmitir conhecimento científico.

As concepções de Bakhtin (1997) sobre a relação entre as esferas da atividade humana e a utilização da língua correspondem a um conjunto de conceitos dos mais referidos em vários campos de estudos, principalmente os linguísticos. Para esse autor, a utilização da língua se dá "em forma de enunciados (orais e escritos), concretos e únicos, que emanam dos integrantes duma ou doutra esfera da atividade humana” (1997, p. 280), enunciados esses que, 
se considerados isoladamente, são individuais, porém refletem condições específicas e finalidades de cada uma dessas esferas, no seu conteúdo temático, estilo verbal ou construção composicional, elementos que se fundem de forma indissolúvel no todo do enunciado: os gêneros do discurso.

Marcuschi (2008, p. 154) adota a posição de que é impossível comunicar-se verbalmente a não ser por meio de um gênero textual, expressão que, para ele, pode ser considerada, na maioria das vezes, equivalente a gênero discursivo, posicionamento que justifica termos adotado o termo gênero textual-discursivo. $\mathrm{O}$ autor afirma que dominar um gênero textual não significa que temos o domínio sobre uma forma linguística, mas que dominamos "uma forma de realizar linguisticamente objetivos específicos em situações sociais particulares”. Complementando essa posição, Marcuschi (2008) observa que o gênero textual refere-se aos textos com que nos deparamos na vida diária, materializados em situações comunicativas recorrentes, com padrões sociocomunicativos definidos por "composições funcionais, objetivos enunciativos e estilos concretamente realizados na integração de forças históricas, sociais, institucionais e técnicas. " (MARCUSCHI, 2008, p. 155)

Em concordância com a visão sociointeracionista adotada como perspectiva teórica de seus estudos linguísticos sobre o texto, esse estudioso salienta:

Assim, em última análise, a distribuição da produção discursiva em gêneros tem como correlato a própria organização da sociedade, o que nos faz pensar no estudo sócio-histórico dos gêneros textuais como uma das maneiras de entender o próprio funcionamento social da língua. (MARCUSCHI, 2008, p. 208)

Ao relacionar a questão cultural ao funcionamento social, Marcuschi (2008, p. 163) afirma que a vivência cultural humana está sempre relacionada à linguagem e que todos os nossos textos estão situados nessas vivências estabilizadas em gêneros; portanto, o conceito de que a língua é "uma atividade sociointerativa de caráter cognitivo, sistemática e instauradora de ordens diversas na sociedade" é fundamental. Para ele, a língua é uma forma de ação e de exercício de influência, portanto seu funcionamento no dia a dia é um processo de integração social, pois com ela agimos e produzimos sentido.

Ainda segundo Marcuschi (2008), o gênero - prática textual e prática textual discursiva - opera como a ponte entre o discurso, atividade mais universal, e o texto, peça empírica configurada numa composição observável. $\mathrm{O}$ autor afirma que produzir um texto de determinado gênero leva a uma série de escolhas formais e funcionais condicionadoras de 
uma esquematização textual, citando inclusive como exemplo a produção de um artigo científico, que "seguirá uma espécie de roteiro que deve desenvolver um conjunto de esquemas e de configurações bastante nítidas. " (MARCUSCHI, 2008, p. 84)

Esse estudioso cita didaticamente o exemplo da atividade discursiva na vida acadêmica, que consiste na produção de gêneros como ensaios, teses e artigos científicos, como forma de dar legitimidade ao discurso do pesquisador, configurando prestígio e até impondo determinada forma de fazer ciência e decidir o que é ou não é científico. O autor adverte, porém, que o controle social pelos gêneros discursivos é incontornável, mas não determinista - não somos livres para decidir o que e como produzir, pois fazemos parte de uma sociedade que nos molda e dirige a ações determinadas. Por outro lado, "o gênero textual não cria relações deterministas nem perpetua relações, apenas manifesta-as em certas condições de suas realizações. ". Para Marcuschi, boa parte de como se manifestam nossa inserção social e nosso poder social depende do modo como dominamos e manipulamos esse poderoso instrumento que são os gêneros textuais. (MARCUSCHI, 2008, p.162)

Complementando a ideia de que os gêneros são formas textuais escritas ou orais bastante estáveis, pois são histórica e socialmente situadas, Marcuschi (2008, p. 155), ao desenvolver posteriormente o tema, adverte que, na posição bakhtiniana sobre a relativa estabilidade do gênero em termos de sua natureza histórica, sociointeracional, ideológica e linguística, a noção de relatividade sobrepõe-se à de estabilidade. Para aqueles preocupados com a afirmação da forma, interessa a estabilidade, mas "a noção de relatividade parece sobrepor-se aos aspectos estritamente formais e captar melhor os aspectos históricos e as fronteiras fluidas dos gêneros". Nesse sentido, diz que devemos considerar os gêneros como entidades dinâmicas, "formas culturais e cognitivas de ação social corporificadas de modo particular na linguagem" e não como modelos estanques ou estruturas rígidas. (MARCUSCHI, 2011, p. 18)

Marcuschi (2011, p. 19) ainda comenta a crise que vem atingindo as teorias sobre gêneros que privilegiam a forma ou a estrutura, em oposição à tendência aos estudos que tomam o gênero como flexível e variável, observando seu lado dinâmico, processual, social, interativo e cognitivo, visto que seu principal componente, a língua, varia, adapta-se, renovase e multiplica-se. Essa posição é de extrema importância para este estudo, pois, apesar de considerarmos importante que se identifiquem estruturas composicionais razoavelmente estáveis e, portanto, ensináveis, também é fundamental considerar as variações dinâmicas de realização textual dentro do gênero, também passíveis de serem verificadas e ensinadas, se for 
observado um número bastante significativo dessas realizações por meio de leitura e análise. Essa posição reflete na escolha de uma determinada maneira de utilizar a teoria dos gêneros como inspiração didática, como se esclarecerá a seguir.

\subsubsection{Ensinar produção textual com base na teoria dos gêneros}

Merece ser valorizado o trabalho de pesquisa que realizam estudiosas brasileiras como Lopes-Rossi (2011) e Motta-Roth (2011), por retomarem ideias que nos são caras. LopesRossi (2011, p. 71), ao tratar do ensino de leitura e produção de textos, fundamentada, em grande parte, na teoria dos gêneros discursivos de Bakhtin ([1979]1997), afirma que é por meio de tais gêneros que "as práticas de linguagem incorporam-se às atividades dos alunos". Segundo a autora, cabe ao professor criar condições para que seus alunos dominem o funcionamento da linguagem em situações reais de comunicação e apropriem-se das características discursivas e linguísticas de gêneros diversos, o que pode acontecer por meio de projetos pedagógicos que promovam o conhecimento, a leitura, a produção escrita e a discussão sobre a utilização, o funcionamento e a circulação social dos gêneros escolhidos. Lopes-Rossi indica:

As atividades de leitura, em cada caso, devem levar os alunos a perceber que a composição do gênero - em todos os seus aspectos verbais e não verbais, nas informações que apresenta ou omite, no destaque que dá a algumas, mais do que a outras - é planejada de acordo com sua função social e seus propósitos comunicativos. Isso contribui para a formação de um cidadão crítico e participativo na sociedade. (LOPES-ROSSI, 2011, p. 71)

Referindo-se a trabalhos na área de Linguística Aplicada com o objetivo de estudar a "linguagem usada em contextos específicos e sua função constitutiva de papéis e relações sociais para alcançar determinados objetivos comunicativos”, Motta-Roth (2011, p. 154) também reflete sobre possibilidades de análise e ensino de gêneros por meio da observação da estreita relação entre contexto e texto. A autora propõe a construção de bases teóricas comuns que possam levar a conhecer os contextos que geram e são constituídos pelo texto, com o intuito de perceber e definir aspectos de linguagem relevantes para analisar e ensinar um gênero. Segundo essa autora:

O modo como nos apropriamos do universo e das informações que nos cercam e os incorporamos a nosso repertório cognitivo, representando, descrevendo, avaliando por meio da linguagem, é função de nossa própria 
condição humana. Entretanto esse processo de apropriação é moldado pela interação dialógica com o mundo. (...) Nesses termos, vale dizer que o conhecimento humano é construído através de gêneros - linguagem usada em contextos recorrentes da experiência humana - socialmente compartilhados. (MOTTA-ROTH, 2011, p. 155)

Motta-Roth (2011, p. 156) considera gêneros "atividades culturalmente pertinentes, mediadas pela linguagem num dado contexto de situação, atravessado por discursos de ordens diversas", e propõe a exploração de gênero como "fenômeno estruturador da 'cultura' que, por sua vez, se constitui como um conceito complexo, que pode sofrer vários recortes. " A autora sugere uma série de procedimentos investigativos - já referidos na seção de procedimentos metodológicos da Introdução deste trabalho - com dois propósitos principais: investigar quais traços ou elementos da linguagem são relevantes em um dado texto, e estabelecer a conexão entre o texto e o contexto, enquanto condições de significação e interpretação. (p. 156)

De qualquer forma, retomando e combinando as ideias de Bakhtin ([1979]1997), Marcuschi (2008, 2011), Lopes-Rossi (2011) e Motta-Roth (2011), podemos dizer que fazem parte do gênero textual-discursivo artigo científico enunciados com função comunicativa que são realizações linguísticas reais, únicas e constitutivas de papéis e relações sociais no âmbito da construção do saber científico e que refletem o contexto e as condições e finalidades específicas da esfera acadêmica em seu conteúdo temático, seu estilo e sua construção composicional. Nesse sentido, consideramos a possibilidade de ensinar a produzir artigos científicos observando tais elementos em sua singularidade, mas sem desprezar sua interrelação e a reciprocidade em que ocorrem.

Nossa opção por estudar o gênero artigo científico situando-o no contexto acadêmico e observando sua função comunicativa, requer, conforme já vimos anteriormente em LopesRossi (2011, p. 71), que se promova o encontro dos alunos com tal gênero por meio de leitura, análise e discussão de artigos científicos já publicados. A questão temática, a organização das principais seções e os elementos linguísticos utilizados em cada uma delas podem ser apontados por meio desse primeiro contato com o texto, para que os estudantes se apropriem, a princípio intuitivamente, dessas características. Somente depois desse primeiro contato com os textos reais, a fundamentação teórica é apresentada.

Por concordamos com Motta-Roth (2011, p.161), quando essa pesquisadora afirma que "estudar linguagem parece ser nada além de estudar a interação humana", tema já abordado no capítulo anterior, também consideramos conveniente sua proposta de formar um 
corpus "estudável" - um conjunto de textos pertinentes ao contexto em que se dá determinada interação social - analisado para identificarem-se elementos textuais relevantes. Dessa forma, a definição das categorias de análise a serem estudadas aconteceria a partir da observação da recorrência de certos elementos textuais, com frequência suficiente para se tornarem convencionais e significativos entre os vários exemplares de textos. (MOTTA-ROTH, 2011, p. 164)

As atividades de produção textual propostas neste estudo consideram sempre a formação de um corpus de consulta composto por textos que, por terem sido efetivamente utilizados nos domínios dos gêneros que se pretende estudar, representam exemplos observáveis da linguagem em uso. A leitura e análise de tais textos consistirão em maneira empírica de abordar o objeto de estudo artigo científico, para que se conheçam sua funcionalidade, suas características composicionais, as condições de produção e o contexto em que foi produzido, além de possibilitar a observação de traços de linguagem recorrentes e, portanto, relevantes para o ensino da produção textual de tal gênero. Um conjunto de links que dão acesso aos artigos que compõem tal corpus se encontra reproduzido no ANEXO A da seção de ANEXOS, mas deve ser entendido como o instantâneo de uma aplicação e não como conjunto definitivo de textos, a se considerar a dinamicidade dos gêneros e a adequação de tal corpus a cada audiência a que se destina.

Em complementação a esse primeiro contato com os textos reais por meio da leitura, da análise e da discussão, propomos examinar as ideias de alguns teóricos que apresentam maneiras de analisar e organizar textos, como Van Dijk (1980), que aborda o tema de forma mais abrangente por meio da noção de unidade global, com papel importante em várias disciplinas, e Swales (1990), Swales e Feak (1994, 2004, 2012), que adotam uma abordagem retórica para o ensino de gêneros acadêmicos, entre outros.

\subsubsection{Macro, micro e superestruturas}

De modo mais geral, a escolha de trabalhar a produção textual por meio da teoria do gênero implicou, no caso das aplicações dessa proposta, apresentar aos alunos um conjunto de exemplares do gênero artigo científico para que fossem observados os elementos que os caracterizam. Formou-se, para tanto, o já citado corpus de consulta, um conjunto que varia de acordo com a audiência do curso, principalmente na questão temática. Elementos como o 
estilo e a construção composicional, a se considerar a nomenclatura bakhtiniana, também são observados, já que uma abordagem discursiva de ensino leva em conta cada aspecto, mas conhece sua indissociabilidade e a recíproca influência na construção de sentido no texto/discurso.

Embora admitamos outras possibilidades de encaminhamento, decidimos retomar os conceitos de macro, micro e superestrutura propostos por Van Dijk, estudioso da cognição e particularmente do processamento de informação complexa já na década de 80 , por considerálos pertinentes à nossa pesquisa. Esse autor afirma que os domínios mais específicos do uso linguístico e do discurso estão relacionados à ação social e à interação, representando funções cognitivas fundamentais do organismo humano. Ao justificar a importância de analisar sistematicamente as estruturas globais presentes em diversos domínios, incluídos o uso linguístico e o discurso, Van Dijk diz:

Quando falamos ou escrevemos, realizamos certos tipos de ações sociais, isto é, atos de fala, que desempenham papel importante na interação social. Em ambos os casos, o processamento de informação complexa está envolvido e assume-se que tal processamento de informação complexa não é possível sem a distinção teórica e cognitiva entre estruturas locais e globais. ${ }^{35}$ (VAN DIJK, 1980, p. 5)

Ainda segundo esse autor, o estudo das chamadas de unidades globais tem papel fundamental nas ciências humanas e sociais como a teoria linguística do discurso, a análise da conversação, a microssociologia, a psicologia cognitiva e a inteligência artificial. Para Van Dijk (1980, p. v), tais unidades globais são registradas em termos de macroestruturas e, em relação aos domínios textuais-discursivos, podem ser definidas como "estruturas semânticas e conceituais de nível superior que organizam as microestruturas 'locais' do discurso, da interação e do processamento cognitivo de ambos. "36

Esse estudioso afirma que as macroestruturas são necessárias para o entendimento, a organização e a compressão de informações complexas, pois, sem elas, não seria possível planejar ou executar sequências e discursos na interação, bem como compreender, guardar na memória, recordar e recuperar tais discursos.(VAN DIJK, 1980, p. vi) O autor assegura que os usuários da língua, de modo implícito ou explícito, reconhecem intuitivamente a distinção

\footnotetext{
35 Tradução livre de: When we speak or write, we accomplish certain kinds of social acts, viz. speech acts, which play an important role in social interaction. In both cases complex information processing is involved, and it will be assumed that such complex information processing is not possible without the theoretical and cognitive distinction between local and global structures. (VAN DIJK, 1980, p. 5)

${ }^{36}$ Tradução livre de: Macrostructures are higher-level semantic or conceptual structures that organize the 'local' microstructures of discourse, interaction, and their cognitive processing. (VAN DIJK, 1980, p. v)
} 
entre estruturas locais e globais do discurso e podem mostrar-se conscientes da realidade cognitiva dessas estruturas por produzirem um metadiscurso sobre elas. (VAN DIJK, 1980, p. 1)

Em exemplos que revelam noções intuitivas da fala cotidiana como: "Eu não me lembro exatamente do que ele disse, mas sua opinião era...”, Van Dijk (1980) encontra indícios da intuição de que as macroestruturas estão mais ligadas ao sentido. Se, por um lado, os usuários da língua falam sobre detalhes do que foi dito em uma conversa, como palavras e frases, por outro, usam termos como 'opinião' e 'tema' para caracterizar tal conversa como um todo. Pode-se perceber que as noções utilizadas em referência ao discurso como um todo em oposição às suas partes, as microestruturas - dizem respeito ao sentido ou ao conteúdo e não ao estilo ou à ordenação das partes, o que significa que a unidade global, ou macroestrutura, deve ser referida em termos semânticos. (VAN DIJK, 1980, p. 5)

Van Dijk (1980, p. 5) acrescenta que, além dessas estruturas globais de caráter semântico, existem ainda aquelas de natureza mais esquemática, cujo papel é ordenar ou atribuir noções como esboço, construção e ordem aos significados globais do discurso. Para exemplificar tais estruturas globais esquemáticas, o autor cita a organização específica de um artigo científico, em que termos intuitivos como introdução, base teórica, desenvolvimento e conclusão indicam algumas das categorias formais envolvidas. Para diferenciar as estruturas globais semânticas, as chamadas macroestruturas, das esquemáticas, que dizem respeito à forma global do discurso, Van Dijk cria o termo 'superestruturas'. Ele diz:

Para distinguir estruturas globais esquemáticas, que dizem respeito à "forma" global do discurso, das estruturas globais de significado para os quais são utilizadas noções como "tema", "tópico" ou "essência", usamos o termo teórico específico superestruturas. ${ }^{37}$ (VAN DIJK, 1980, p. 6)

Esse autor afirma que não se dá conta de analisar o discurso apenas por seu micronível, ou seja, não se podem observar somente as microestruturas diretamente expressas no discurso, como palavras, frases, sentenças e conexões entre sentenças. É preciso também considerar uma interpretação macroestrutural como condição necessária para a interpretação de sentenças e o estabelecimento da coerência local no micronível. Relacionando-se ainda o conceito de superestrutura como forma esquemática organizadora do sentido global de um

\footnotetext{
${ }^{37}$ Tradução livre de: To distinguish schematic global structures, which pertain to the global "form" of the discourse, from the global meaning structures for which notions such as "theme," "topic," or "gist" are used, we use the specific theoretical term superstructures. (VAN DIJK, 1980, p. 6)
} 
texto $^{38}$, poderíamos dizer que, para Van Dijk (1980, p. 29), analisar o discurso supõe especificar como as micro, macro e superestruturas determinam e são determinadas umas pelas outras.

Essas noções são particularmente relevantes para o presente estudo no sentido de que a proposta de ensino de produção textual que apresentamos considera o artigo científico sob todos esses pontos de vista, abordando: questões semânticas de tema e tópico, quando contempla as singularidades das diversas áreas de interesse dos participantes; questões esquemáticas de organização do sentido global do texto, quando observa as formas possíveis de produzir e conectar seções do artigo como resumo, introdução, fundamentação teórica, conclusão, etc.; e questões referentes às microestruturas textuais, quando considera a adequação das formas diretamente expressas no discurso relativamente à sua função de expressar o conhecimento científico obtido. Além disso, observa-se ainda a maneira como tais estruturas influenciam umas às outras.

Outras perspectivas com as quais estamos em concordância no que diz respeito especificamente à abordagem pedagógica da produção da escrita acadêmica estão expressas em Castelló e Iñesta (2012), em Swales (1990) e Swales \& Feak (1994, 2004, 2012), uma proposta retomada, desenvolvida e adequada ao ensino em língua portuguesa por Motta-Roth e Hendges (2010), como veremos a seguir.

\subsubsection{Textos como Artefatos em Atividade}

Castelló e Iñesta (2012, p. 179), pesquisadoras espanholas que se dedicam à investigação da escrita acadêmica sob a perspectiva de ensino e aprendizagem, abordando questões de identidade autoral na escrita de artigos por parte de alunos, afirmam que atualmente a escrita acadêmica é considerada uma atividade social e culturalmente situada, inserida num microcontexto de situações comunicativas específicas que fazem sentido de acordo com o macrocontexto histórico e cultural em que ocorrem. Essas estudiosas dizem que os estudantes/escritores, ao lidarem com a aprendizagem dentro do ambiente acadêmico, participam de várias comunidades embutidas em complexos sistemas de atividades e que, para

\footnotetext{
${ }^{38}$ Tradução livre de: (...) superstructure is the schematic form that organizes the global meaning of a text. (VAN DIJK, 1980, p. 108)
} 
melhor compreender essa prática social participativa que é a escrita na universidade, é preciso ter consciência das tensões e contradições envolvidas em tais atividades.

Castelló e Iñesta (2012, p. 180) consideram textos 'Artefatos em Atividade' (Artifactsin-Activity) e, para esclarecer tal posicionamento, traçam um perfil dos textos que os estudantes de ensino superior devem produzir. Seguindo a classificação proposta por Russel e Cortes $(2012$, p. 3), essas autoras consideram tais textos pertencentes a um gênero específico situado entre os textos acadêmicos produzidos como parte das atividades de graduação - para serem lidos por professores - e os científicos, produzidos para serem publicados e lidos pela comunidade de pesquisa correspondente. Optam inicialmente por fazerem uma distinção entre os termos 'acadêmico' e 'científico' e dizem:

A Escrita de Texto Acadêmico de Pesquisa (ETAP) implica dois processos complexos. Primeiro os alunos precisam ser capazes de pensar e agir como pesquisadores enquanto desenvolvem seus estudos de pesquisa. Depois eles precisam comunicar adequadamente os resultados de sua pesquisa no gênero específico de Texto Acadêmico de Pesquisa (TAP). (CASTELLÓ e INESTA, 2012, p. 180) ${ }^{39}$

Essas pesquisadoras acrescentam que, para uma prática bem-sucedida, os alunos devem estar cientes das principais funções da escrita acadêmica; a primeira, a saber, a função epistêmica, que envolve a construção e a transformação de conhecimento, levando em conta as bases teóricas já estabelecidas pelo campo de pesquisa escolhido. O papel epistêmico da escrita acadêmica se dá como construção conjunta de significado inserida em uma dimensão histórica e, portanto, não pode ser exclusivamente baseada nas características individuais do escritor. (CASTELLÓ e IÑNETA, 2012, p. 180)

A segunda, a função dialógica da escrita acadêmica, refere-se ao diálogo que o escritor/estudante estabelece com outros membros da comunidade acadêmico-científica e por meio do qual aquele se alinha a uma ou outra teoria e aos correspondentes autores. Uma terceira função da escrita de pesquisa corresponde ao estabelecimento e manutenção de redes de influência, pois cada texto revela a importância que o escritor/estudante atribui às diferentes vozes invocadas nele. (CASTELLÓ e IÑESTA, 2012, p. 180)

\footnotetext{
${ }^{39}$ Tradução livre de: Academic research paper writing (ARPW) implies two complex processes. On the one hand, students need to be able to think and act as researchers when developing their research study. On the other hand, they need to appropriately communicate the results of their research in the specific genre of the ARP. (CASTELLÓ e IÑESTA, 2012, p. 180)
} 
A quarta função é a comunicativa, que envolve a divulgação e compartilhamento do conhecimento registrado por escrito com outros membros da comunidade de qual o escritor/estudante faz parte. Essa função é reforçada se houver o cumprimento das expectativas dos leitores no que se refere ao grau de adequação às convenções do gênero discursivo adotado. Por fim, escrever textos acadêmicos contribui para a construção de uma identidade social dos alunos como pesquisadores e autores acadêmicos, realizada por meio do diálogo que eles estabelecem com os diferentes atores envolvidos nesse processo de coautoria mais ou menos explícita que ainda não conhecem muito bem. (CASTELLÓ e IÑESTA, 2012, p. 181)

Castelló e Iñesta (2012) apontam para a complexidade que envolve a produção de escrita acadêmica como razão para considerarem textos 'Artefatos em Atividade', em oposição ao conceito de 'textos como produtos finais de pensamento'. Elas creem que eles, os textos, sejam "ingredientes centrais em torno dos quais o processo de construção de significado que as atividades de pesquisa e escrita envolvem é articulado e por meio do qual a identidade discursiva do autor é forjada e tornada visível para os leitores. "(CASTELLÓ e INESTA, 2012, p. 181) ${ }^{40}$

Na prática de atividades que propuseram como intervenção educacional, essas autoras sugerem o aumento da complexidade das representações que os alunos têm sobre a Escrita de Texto Acadêmico de Pesquisa (ETAP), com o intuito de promover neles a aquisição de estratégias para gerenciar e regular eficientemente sua própria atividade escrita, o que elas consideram um dos maiores desafios das propostas instrucionais centradas na escrita acadêmica na universidade. Segundo as autoras, "resumidamente, adquirir tais estratégias requer que os estudantes reflitam sobre suas intenções e objetivos quando escrevem cada texto em particular, e regulem suas práticas de escrita de modo a alcançar esses objetivos. "41 (CASTELLÓ e IÑESTA, 2012, p. 182)

Segundo as autoras, embora os universitários tenham incorporado estratégias linguísticas que deem conta de expressar por escrito o que já sabem, a maioria deles ainda não

40 Tradução livre de: ... central ingredientes around which the meaning construction process that the research and writing activities envolve is articulated and whereby the author's discoursal identity is forged and made visible to the readers. (CASTELLÓ e IÑESTA, 2012, p. 181)

${ }^{41}$ Tradução livre de: In short, acquiring such strategies requires students to reflect on their intention and objectives when writing every particular text, and to regulate their writing practices so as to fulfill these objectives. (CASTELLÓ e INESTA, 2012, p. 182) 
aprendeu como ajustar o conhecimento dos próprios objetivos retóricos e discursivos para produzir textos acadêmicos complexos. Tal aprendizado requer que os novos pesquisadores lidem com a combinação híbrida de leitura e escrita, orientada inicialmente para conhecer seu campo de pesquisa, um processo de construção de conhecimento que justapõe muitas vozes. Adquirida tal expertise sobre a área de pesquisa, é necessário construir uma arquitetura argumentativa que, além de estruturar seu posicionamento como pesquisador, mantenha-o dentro das fronteiras conceituais de sua comunidade acadêmica específica. (CASTELLÓ e IÑESTA, 2012, p. 182)

Tais desafios, segundo Castelló e Iñesta (2012, p. 182), não são adequadamente vencidos simplesmente com a aplicação de técnicas de planejamento ou revisão, ou ainda por apresentar ao estudante as macroestruturas ou os recursos linguísticos presentes nos artigos científicos. Para lidar com a complexidade desse processo e tirar dele o máximo proveito, é necessário implementar estratégias de regulação da escrita que são inseparáveis das representações de texto que o autor tenha construído, bem como dos sucessivos rascunhos que constituem atualizações do "texto ensaiado".

O que vai determinar o tipo de estratégia de ensino a ser utilizada é o estágio de desenvolvimento da arquitetura argumentativa que o autor atingiu, materializado nas especificidades do rascunho por ele produzido. Portanto, o que os alunos pesquisadores precisam aprender não se reduz a conhecer recursos linguísticos; é preciso que saibam quando, como e para atender a qual objetivo seu uso é requerido, tomando por base seus próprios textos. Desenvolver atividades que permitam aos estudantes usar estratégias de produção textual aprendidas pode ajudá-los a apresentar suas ideias de forma convincente perante a comunidade acadêmica.

Tais atividades podem envolver tanto um processo compartilhado, em que um autor menos experiente internalize estratégias reguladores próprias, graças ao diálogo com outros membros de sua comunidade, especialmente com seu professor ou orientador, quanto uma tomada de decisões e a realização de revisões de modo colaborativo com seus colegas estudantes. Em resumo, Castelló e Iñesta (2012, p. 183) afirmam:

Todas essas modalidades de regulação objetivam desenvolver no estudante consciência e conhecimento relativos: a) ao conteúdo sobre o qual eles estão escrevendo e o estabelecimento de novas relações conceituais; b) aos mecanismos discursivos e os recursos linguísticos valorizados em cada 
comunidade específica; c) às dimensões emocionais e identitárias envolvidas na regulação da escrita acadêmica. ${ }^{42}$

Assumimos, no presente estudo, juntamente com Castelló e Iñesta (2012), a importância de os novos pesquisadores conhecerem as funções da escrita acadêmica, considerada prática social participativa; refletirem sobre suas intenções e objetivos; conhecerem seu campo de pesquisa por meio da leitura de textos já escritos pela comunidade científica de que fazem parte; considerarem suas produções como passíveis de diversas atualizações, não só em relação ao tema desenvolvido, mas também em termos de uso de superestruturas e de recursos linguísticos, mediante a aquisição de estratégias de regulação da própria escrita, com base na arquitetura argumentativa já atingida em sua produção textual.

Interessa ainda observar a distinção que as autoras fazem entre os termos "textos acadêmicos", produzidos na graduação para serem lidos por professores e orientadores, e "textos científicos", produzidos com o objetivo de publicação na comunidade científica, situando, entre os dois, o que elas denominam Texto Acadêmico de Pesquisa (TAP), considerado por elas um gênero específico.

Acreditamos que, apesar de reconhecermos a diferença entre as audiências a que as produções se destinam, denominá-los "textos acadêmicos", "textos científicos" ou "textos de pesquisa" não estabelece essa distinção, pelo menos em termos de ensino de sua produção. A nosso ver, todas essas denominações são adequadas aos textos produzidos com a finalidade de expressar os resultados de uma pesquisa realizada no ensino superior, indiferentemente de serem destinados a professores ou à publicação nos periódicos especializados. Por motivo de este estudo ter objetivos pedagógicos, optamos por empregar as três opções como equivalentes em significado, bem como utilizar alternadamente os termos "artigo científico" e "artigo acadêmico", que também consideramos bastante próximos.

Outro teórico cujas propostas referentes ao ensino de gêneros acadêmicos em Língua Inglesa inspiraram esta pesquisa é o linguista John Swales, que apresenta os movimentos retóricos que o autor do texto acadêmico precisa efetuar para conquistar a adesão do leitor às suas ideias, como veremos a seguir.

42 Tradução livre de: All these academic writing regulation modalities aim to develop students' awareness and knowledge regarding: (a) the content they are writing about and the establishment of new conceptual relations; $(b)$ the discursive mechanisms and linguistic resources that are valued in each specific community; (c) the emotional and identity-related dimensions involved in academic writing regulation. (CASTELLÓ e IÑESTA, 2012, p. 183) 


\subsubsection{Sociorretórica de Swales}

Em estudos iniciais envolvendo áreas específicas de linguagem para fins de aprendizagem, destacando o ensino de língua inglesa para fins acadêmicos, Swales (1990) desenvolve uma abordagem que considera a análise e o exame de diferentes gêneros para torná-los acessíveis aos alunos. O autor concebe uma abordagem retórica, baseada em pesquisa e experiência de ensino com os gêneros da escrita acadêmica, e vem continuamente publicando e atualizando obras sobre o tema em parceria com Feak (SWALES e FEAK, 1994, 2004, 2012).

Ao introduzir a terceira edição da obra, os autores reconhecem tanto a crescente incorporação da escrita em contextos sociais e profissionais quanto a ampliação das atividades acadêmicas, nas universidades americanas e de diversos outros países, por conta da universalização da internet desde a propagação das tecnologias wireless. A tendência a conectar-se e colaborar virtualmente torna a escrita acadêmica hoje uma atividade muito mais cooperativa do que costumava ser, constituindo uma forma de socialização acadêmica. (SWALES e FEAK, 2012)

Seguindo o modelo bem-sucedido das duas primeiras edições, os autores mantêm a abordagem que se preocupa tanto em formar escritores acadêmicos quanto em melhorar os textos propriamente ditos. Com tom coloquial e dirigindo-se diretamente a um leitor que decidem assessorar no exercício de explorar, conhecer e escrever textos acadêmicos, os autores vão propondo tarefas variadas, que incluem desde questionamentos sobre que elementos priorizar numa conclusão para que o estudante estabeleça um posicionamento e crie uma imagem de credibilidade em seu campo de atuação, até exercícios mais específicos sobre usos linguísticos.

O enfoque geral de Swales e Feak (2012, p. ix) é analítico e retórico, sendo que os estudantes são estimulados a aplicar suas habilidades analíticas aos discursos de suas disciplinas e a explorar o grau de eficácia a ser atingido com sua produção escrita, num processo que eles denominam "elevação da consciência retórica". ${ }^{43}$ Para cada etapa do texto

43 Tradução adaptada de: The general approach is analytical and rhetorical: Users are asked to apply their analytical skills to the discourses of their chosen disciplines and to explore how effective academic writing is achieved. In effect, we are strong believers in this cycle, which is fashionably known as rhetorical consciousness raising ... (SWALES e FEAK, 2012, p. ix) 
acadêmico, os autores sugerem diferentes "movimentos retóricos", comparáveis a movimentos de um jogo de xadrez, o que envolve, além da dinâmica de avançar, a intenção de alcançar, por meio da utilização de determinados recursos linguísticos, o objetivo de convencer o interlocutor a ler o texto produzido e aderir aos argumentos nele defendidos.

Os conceitos e atividades de Swales e Feak (2012), com os quais concordamos em parte, dizem respeito ao fato de que a escrita acadêmica é produto de muitas considerações como: audiência, objetivo, organização, estilo, fluxo e apresentação ${ }^{44}$, conforme mostra o gráfico a seguir, com uma tradução nossa de figura retirada da referida obra à página 3:

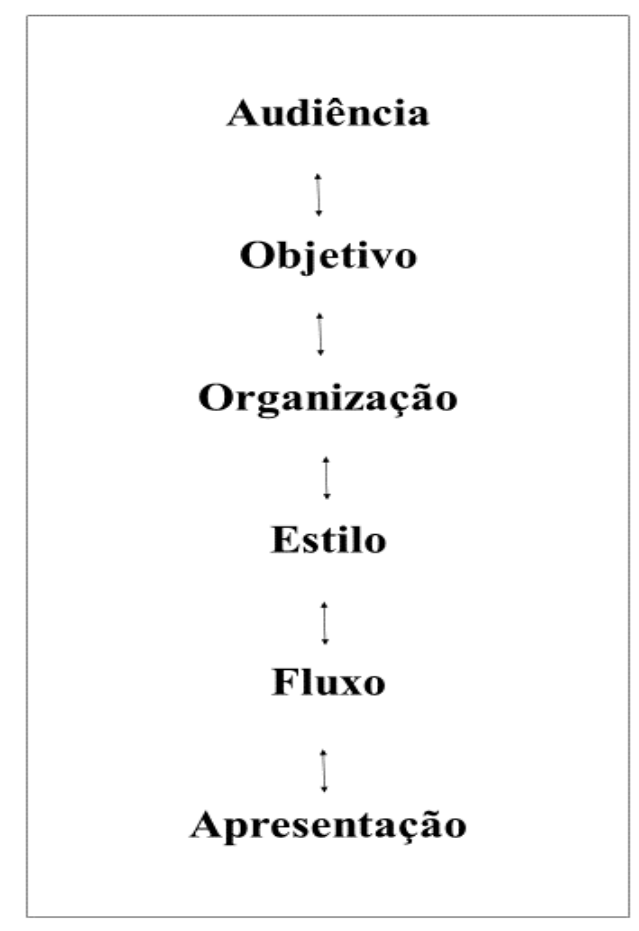

Figura 2: Considerações sobre escrita acadêmica (SWALES e FEAK, 2012, p. 3)

Swales e Feak (2012, p. 4) aconselham o estudante a considerar a audiência, ou seja, seu interlocutor, antes mesmo de começar a produzir seu trabalho acadêmico. Professores, orientadores, organizadores de eventos e colegas que pesquisam a mesma área podem compor essa audiência, e conhecê-la bem vai influenciar o processo de escrita, pois a familiaridade desse leitor/interlocutor com o tema abordado pode ser determinante para a escolha das informações que o trabalho deve conter. Além disso, o conhecimento da audiência influencia

${ }^{44}$ Tradução livre de: ... academic writing is a product of many considerations: audience, purpose, organization, style, flow and presentation. (SWALES \& FEAK, 2012, p. 3) 
diretamente o objetivo e a escolha da estratégia. Esses autores afirmam que, em geral, a situação mais comum enfrentada pelo graduando é o fato de sua audiência saber mais que ele, portanto seu objetivo seria demonstrar familiaridade e conhecimento sobre o tema abordado, escolhendo estratégias que conquistem a adesão dessa audiência, como evitar repetir-se, apresentar os resultados conectando-os a temas mais abrangentes, etc. (SWALES e FEAK, 2012, p. 6)

Quanto à organização, Swales e Feak (2012, p. 8) afirmam que pode ser vantajoso apresentar um texto num formato já pré-estabelecido, o que vai ao encontro das expectativas do leitor. Em relação ao estilo, os autores dizem que ele deve ser não só consistente, mas adequado tanto à mensagem quanto à audiência, prevalecendo a linguagem formal, embora haja possíveis variações dependendo da área de estudo, como no caso dos usos de verbos na voz passiva e de primeira pessoa do singular, aceitos em algumas disciplinas, mas não em outras. Esses estudiosos admitem que há muito de vago em tudo o que se encontra, seja na literatura especializada, seja na internet, sobre o estilo acadêmico, por isso optam por reservar seções que têm como foco questões bastante específicas de uso linguístico do inglês para fins acadêmicos, como a preferência por uma única forma verbal ao invés de verbos compostos, ou a escolha da forma nominal que transmita a ideia de maneira mais precisa. (SWALES e FEAK, 2012, p. 20)

Ainda segundo Swales e Feak (2012, p. 30), o fluxo, ou o estabelecimento de uma clara conexão entre as ideias expressas num texto, é outra consideração importante para uma comunicação bem-sucedida, pois vai ajudar o leitor a acompanhar o texto. Para auxiliar nessa direção, os autores apresentam exercícios que abordam questões de referenciação, uso adequado de conectores e pontuação. Para os autores, em termos de apresentação, mais importante que um texto livre de problemas gramaticais é que haja um bom fluxo de conteúdo e informação, com sentenças bem conectadas umas às outras, em parágrafos claros. Mesmo assim, aconselham considerar a revisão das concordâncias verbal e nominal, a ortografia e conferir se fontes e espaçamentos estão de acordo com o uso comum em cada disciplina. (SWALES e FEAK, 2012, p. 48)

A partir da familiaridade do 'escritor' com essas considerações sobre a escrita acadêmica, Swales e Feak (2012, p. 53) asseguram que ele estará pronto para posicionar-se como novo membro do seu campo de pesquisa. Especificamente em relação à produção de artigos científicos, Swales e Feak (2004, p. 221) afirmam que os autores geralmente operam em um ambiente altamente competitivo, portanto precisam garantir que suas perguntas de 
pesquisa sejam suficientemente interessantes em relação à literatura relevante da área e que ainda não tenham sido respondidas, assumindo um posicionamento cujo objetivo seja confirmar que seus estudos são importantes e significativos e têm novas contribuições a oferecer.

Embora admitam que há inúmeras variações possíveis, dependendo da área de estudo ou mesmo do tipo de pesquisa realizada, os autores apresentam um esquema sobre o que denominam a retórica geral das seções e dos movimentos que nelas ocorrem para a produção do artigo acadêmico, tratado por $R P$ (Research Paper), conforme se vê na figura seguinte, traduzida e adaptada de Swales e Feak (2004):

Introdução (I)

Métodos e

Materiais (M)

Resultados (R)

Discussão (D)
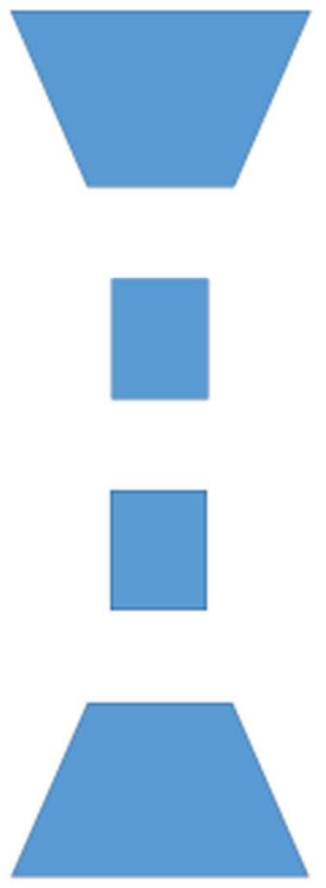

Geral
$\downarrow$
Especifico

Especifico

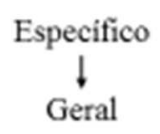

Figura 3: Formato geral de um artigo científico (SWALES e FEAK, 2004, p. 222)

Essa representação gráfica dá uma indicação do movimento inicial, que vai do geral ao específico, e depois do movimento de retomada do específico para o geral, segundo os autores, constituintes de um típico artigo acadêmico. Além disso, Swales e Feak (2004) indicam que as quatro diferentes seções são identificadas por quatro objetivos distintos: 
- Introdução (I): proporciona a justificativa do artigo, movimentando-se da discussão geral do tópico à questão particular ou hipótese a ser investigada. Também tem como objetivo secundário atrair o interesse dos leitores para o tópico.

- Métodos e Materiais (M): descreve a metodologia, os materiais (ou assuntos) e os procedimentos.

- Resultados (R): descreve as descobertas, acompanhadas por comentários.

- Discussão (D): oferece considerações cada vez mais generalizadas sobre o que foi aprendido no estudo, geralmente feitas por meio de uma série de afirmações, em que, pelos menos algumas delas fazem referência às declarações presentes na introdução.

Swales e Feak (2004) observam ainda que, como resultado de apresentarem objetivos diferentes, as quatro seções têm características linguísticas diferentes, e elaboram uma tabela, da qual se fez uma tradução livre, e que vem a seguir:

Tabela 1: Frequência de recursos linguísticos selecionados em seções de Artigos Acadêmicos

(SWALES E FEAK, 2004, p. 223)

\begin{tabular}{|c|c|c|c|c|}
\hline & Introdução & Métodos & Resultados & Discussão \\
\hline Verbos no Presente & alta & baixa & baixa & alta \\
\hline Verbos no Passado & média & alta & alta & média \\
\hline Voz Passiva & baixa & alta & variável & variável \\
\hline Citações & alta & baixa & variável & alta \\
\hline Qualificações & média & baixa & média & alta \\
\hline Comentários & alta & baixa & variável & alta \\
\hline
\end{tabular}

Os autores chamam a atenção para algumas similaridades de usos linguísticos encontradas, por um lado, entre a Introdução e a Discussão, e por outro entre Métodos e Resultados. Segundo Swales e Feak (2004, p. 223), pode-se observar um padrão de seções internas (Métodos e Resultados) mais "concretas", em termos de procedimentos e consequências, e seções externas (Introdução e Discussão), mais conceituais e interpretativas.

De considerável importância para a proposta de ensino que este estudo aborda, a questão da identificação de elementos linguísticos relevantes na produção de um texto pertinente a um dado contexto é citada também por Motta-Roth (2011, p. 163), que afirma ser essa uma questão permanente, seja para a pesquisa sobre gêneros discursivos, seja para o 
ensino e a aprendizagem de línguas. A autora menciona a possibilidade de identificar elementos significativos em qualquer nível - do fonológico ao retórico - a partir da observação de que eles sejam frequentes o bastante para se tornarem convencionais.

Com relação ao estabelecimento de movimentos retóricos que se utilizarão de recursos linguísticos para relatar determinado estudo ou pesquisa em um artigo acadêmico, tornou-se bastante conhecido o modelo CARS (Creating A Research Space) da Introdução de artigos, elaborado por Swales (1990, p. 141) e reformulado em diversas ocasiões, que constitui tanto um instrumento didático quanto de análise da estrutura retórica de introduções em artigos acadêmicos de diferentes áreas. Utilizando a tradução da terminologia encontrada em MottaRoth e Hendges (2010, p. 83), o modelo CARS, de 1990, apresenta a organização retórica de uma Introdução com três movimentos: 1) estabelecer um território de conhecimento; 2) construir um nicho para a pesquisa; 3) ocupar esse nicho. Para cada um desses movimentos, Swales sugere diferentes estratégias retóricas, como no caso do estabelecimento de um território de conhecimento, o que pode ser conseguido se o autor: a) asseverar a importância do assunto e/ou b) fizer generalizações sobre o assunto e/ou c) revisar itens de pesquisa prévia. Para cada passo, há indicação de expressões linguísticas mais ou menos adequadas, (MOTTA-ROTH e HENDGES, 2010, p. 84)

Uma adaptação da figura encontrada em Motta-Roth e Hendges (2010, p. 83), representando detalhadamente o modelo CARS da Introdução de artigos elaborado por Swales (1990, p. 141), vem a seguir: 


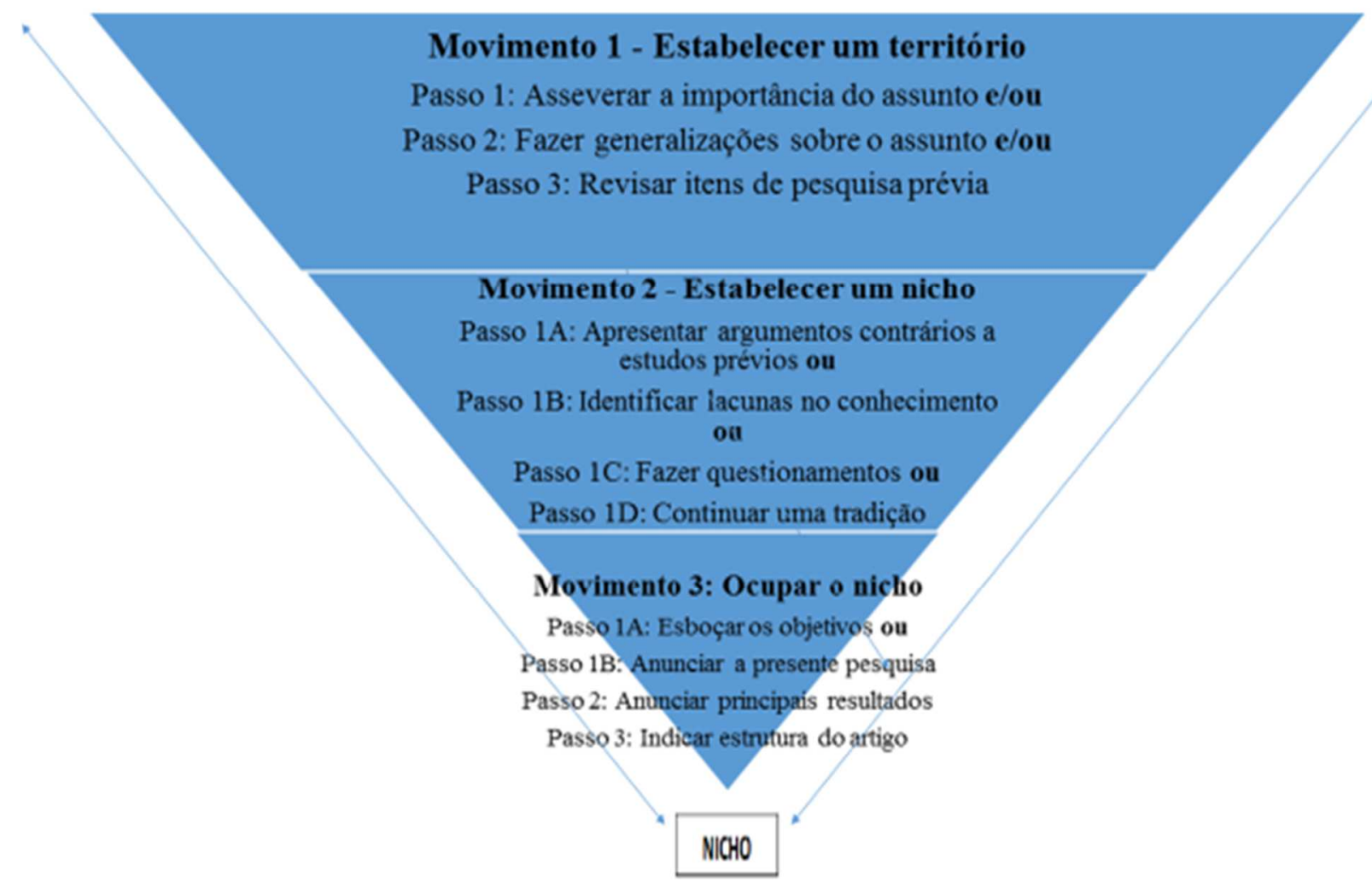

Figura 4: Modelo CARS da Introdução de Artigos (SWALES, 1990, p. 141)

Embora consideremos os estudos de Swales bastante adequados ao ensino de produção de escrita acadêmica, é preciso lembrar que tais estudos foram desenvolvidos para o ensino em Língua Inglesa, em muitas áreas considerada o principal idioma das publicações acadêmicas. Assim sendo, como nos propomos a priorizar o ensino em Língua Portuguesa, por questões já justificadas na Introdução deste trabalho, passamos mais adiante a examinar a proposta de adequar a sociorretórica de Swales (1990) e Swales e Feak (1994, 2004, 2012) ao ensino de escrita acadêmica em língua portuguesa elaborada por Motta-Roth e Hendges (2010).

\subsubsection{Escrita acadêmica em Língua Portuguesa: Motta-Roth e Hendges}

Motta-Roth e Hendges (2010, p. 9) apresentam sua obra na área de produção de gêneros acadêmicos como um material didático que "resulta de uma "reflexão prática" ou da íntima relação entre reflexão teórica e aplicação prática. " (grifo das autoras) Essas 
pesquisadoras têm por objetivos oferecer subsídios a escritores iniciantes, para auxiliá-los a produzir textos acadêmicos na universidade, além de atender à demanda de professores por um material sistematizado para desenvolver as habilidades comunicativas de seus alunos. Tanto a fundamentação teórica quanto a prática pedagógica que as autoras propõem foram construídas com base nos estudos de John M. Swales sobre gêneros discursivos acadêmicos e ensino de línguas, por considerarem que a abordagem sociorretórica que esse autor defende contribua efetivamente ao desenvolvimento do letramento científico.

Motta-Roth e Hendges (2010, p. 14) retomam e ampliam os estudos de Swales e Feak (1994, 2000, 2004) no que diz respeito aos fatores a observar para a produção do texto acadêmico. As autoras incluem, entre as considerações com Audiência, Objetivo, Organização, Estilo, Fluxo e Organização, de Swales e Feak (2012, p. 4), já descritas anteriormente neste capítulo, a definição do Tópico, para a qual a leitura é fundamental, e a Apresentação final do texto, o que implica a revisão a cada versão do texto escrito. Elas afirmam que guardar distanciamento e deixar o texto descansar podem ser estratégias para fazer uma leitura crítica do próprio texto para reorganizar as informações de maneira mais clara, identificar possíveis inadequações gramaticais e posicionar-se de maneira semelhante a outros membros da sua comunidade acadêmica, de sua área de estudo. (MOTTA-ROTH e HENDGES, 2010, p. 22)

Essas estudiosas caracterizam o artigo acadêmico como um texto de aproximadamente dez mil palavras, "produzido com o objetivo de publicar, em periódicos especializados, os resultados de uma pesquisa desenvolvida sobre um tema específico. " Em princípio, é "um documento escrito por um ou mais pesquisadores para relatar os resultados de uma atividade de investigação", um dos principais instrumentos para tornar públicos resultados de pesquisas e estudos avançados essencialmente ligados ao meio universitário. Dessa forma, dissemina conhecimento, condição primordial para o avanço de várias profissões e para a tomada de decisões em diversas instâncias da sociedade. (MOTTA-ROTH e HENDGES, 2010, p. 66)

Motta-Roth e Hendges (2010) citam três principais tipos de artigos, conforme suas características, a saber:

Há o artigo de revisão teórica, que relata uma pesquisa que consiste em um levantamento de toda a literatura publicada sobre um tema (o conceito de identidade na sociologia ou o mal de Alzheimer, por exemplo) em determinado período de tempo (nos últimos vinte anos, de 2000-2010 etc.). Há o artigo experimental, que relata um experimento montado para fins de testagem de determinadas hipóteses (testagem dos efeitos de impulsos elétricos no tratamento de depressão por meio de levantamento estatístico 
em um grupo de pacientes). Há os chamados artigos científicos empíricos, em que o autor ou autores não relatam uma pesquisa desenvolvida em um ambiente experimental controlado, mas reportam a observação direta dos fenômenos conforme percebidos pela experiência (a análise das representações sociais da mulher conforme observadas nos textos que circulam na mídia e nas entrevistas com os jornalistas autores dos textos). (MOTTA-ROTH e HENDGES, 2010, p. 67)

Essas pesquisadoras afirmam que, apesar de o objetivo básico do artigo ser reportar um estudo, é necessário que seu autor convença seu leitor da relevância e da adequação de tal estudo por meio da descrição, exposição e avaliação dos resultados, argumentando e concluindo convencionalmente segundo sua área de estudo, pois cada área tem modos particulares de expressar objetivos, propor metodologias e utilizar a linguagem para argumentar e refletir sobre suas questões.

Motta-Roth e Hendges (2010) utilizam uma dinâmica de procedimentos de progressão textual bem próxima à proposta por Swales e Feak (2004) já apresentada anteriormente na Figura 3, mas sempre admitem variações de nomenclatura conforme especificidades de cada campo de estudo. As autoras dizem que, de forma geral, o texto apresenta a progressão da informação em quatro seções principais: Introdução, Metodologia, Resultados e Discussão, num movimento que transita de um conhecimento amplamente aceito na área (geral), para a construção de um novo conhecimento (específico) e volta às questões da disciplina (geral), indicando a solução do problema apresentado inicialmente, as contribuições da pesquisa para a área e concluindo o estudo.

Uma observação que Motta-Roth e Hendges (2010, p. 70) fazem, e que consideramos essencial, é que a retomada, na Discussão, das questões citadas na Introdução torna essas duas seções "imagens espelhadas uma da outra". Concordamos que, para manter a coerência textual, que também julgamos fator persuasivo para a conquista da adesão da audiência à qual o artigo se destina, a Discussão e a Conclusão não podem deixar de responder às questões propostas inicialmente na Introdução. Apesar de essa colocação parecer óbvia, nossa prática de ensino de texto acadêmico revela a tendência de grande parte dos novos escritores a não dar atenção a essa circunstância.

Como ressalva de ordem geral referente ao planejamento da escrita do artigo, as autoras aconselham a organização do que denominam "mapa semântico", ou seja, um conjunto de conceitos centrais, representado por palavras-chave, que se combinem e estabeleçam relações que delimitem o tema, com o intuito de auxiliar o escritor a manter sua 
linha de discussão e, materializados no texto escrito, também orientem o leitor sobre as principais ideias desenvolvidas.

Ao tomar como base as propostas teóricas e metodológicas de Swales (1990) e Swales e Feak (1994, 2004, 2012), Motta-Roth e Hendges (2010) desenvolvem uma abordagem bastante detalhada, em termos de movimentos retóricos e elementos linguísticos que o autor do texto acadêmico pode utilizar para realizá-los, referentes às várias seções do artigo científico, como Introdução, Revisão da Literatura, Metodologia, Análise e Discussão de Resultados. No caso da Introdução, da qual se apresentará no Capítulo IV a referente sequência didática de aprendizagem combinada, essas pesquisadoras ampliam os termos da Figura 4, já reproduzida anteriormente neste capítulo, apresentando exemplos e atividades de produção textual cujo objetivo seja contextualizar o problema de pesquisa e estabelecer o objetivo e a justificativa do estudo. (MOTTA-ROTH e HENDGES, 2010, p. 73)

Com base na nomenclatura da Figura 4, Motta-Roth e Hendges (2010, p. 84) sugerem algumas estruturas linguísticas com as quais se pode realizar o movimento retórico de estabelecer um território de conhecimento, seja ao asseverar a importância do assunto (Por muito tempo/ nos últimos anos, tem havido um crescente interesse...), ao fazer generalizações sobre o assunto (a maioria dos estudos estabelece/ muitas das perspectivas adotadas descrevem) ou ainda ao revisar itens de pesquisa prévia (de acordo com __, $\mathrm{x}$ é/indica/significa/ y). Dessa forma bastante pormenorizada, as autoras examinam, orientam e sugerem a realização de atividades práticas de produção textual que se refiram a todos os movimentos retóricos necessários para compor as diversas seções do artigo acadêmico.

Estamos em concordância com a relação entre reflexão teórica e aplicação prática que Motta-Roth e Hendges (2010) propõem e consideramos bastante adequada sua aplicação à proposta de ensino de escrita acadêmica que esta pesquisa apresenta, principalmente porque tais práticas podem acontecer por meio de aprendizagem combinada desenvolvida ora em ambiente presencial, ora em meio virtual, ponto central de nossa pesquisa, em virtude de suas funcionalidades particulares, conforme justificaremos adiante no Capítulo 4.

Com relação à escolha de quais aspectos genéricos do artigo científico abordar na proposta de ensino de produção textual aqui estudada, seguimos caminho bem semelhante ao proposto por Motta-Roth (2011, p. 154), pois optamos por apresentar o gênero artigo científico situando-o no contexto acadêmico e conhecendo sua função comunicativa com respeito à expressão do conhecimento científico. Apresentamos a seguir nossa concepção do Artigo Científico, no sentido de que essa foi a maneira que encontramos de transmitir aos 
estudantes quais características esse gênero pode conter em termos de estruturas por meio das quais eles consigam abordar os temas de seus estudos.

\subsubsection{Concepção do gênero Artigo Científico}

A concepção de gênero acadêmico que apresentamos a seguir, elaborada tomando por base artigos científicos da área de Letras, foi construída como resultado de nossa experiência docente e de observações empíricas em alguns periódicos dessa área, como Linha D’Água, Bakhtiniana, Filologia e Linguística Portuguesa, ContraPonto. Admitimos, como Coutinho e Miranda (2009, p. 35), as dificuldades em descrever qualquer gênero por conta de sua natureza mutante e da grande variedade de fatos e critérios que podem interferir em tal descrição. Entretanto, essas autoras admitem que a impossibilidade de uma classificação exaustiva, por meio de um conjunto de parâmetros, não impede a possibilidade de descrição e, portanto, propõem um modelo de análise que observará condições de produção e arquitetura textual.

Encontramos também, em Dolz, Gagnon e Decândio (2010, p. 48), o que esses estudiosos denominam "modelo didático dos gêneros" e classificam como "ferramenta fundamental para organizar o ensino da produção textual por meio dos gêneros". Segundo os autores, o modelo descreveria provisoriamente as principais características de um gênero, para orientar as práticas de ensino. As principais categorias dos componentes desse modelo didático seriam: a situação de comunicação, os conteúdos temáticos, a organização no plano textual, a textualização por meio das unidades linguísticas, os meios paralinguísticos e a paginação do texto.

Silva e Santos (2011, p. 27), autores que se dedicam a estudar gêneros do discurso acadêmico, afirmam que caracterizá-los permite identificar os processos de construção dos textos que os integram. Esses pesquisadores alegam que a explicitação e a sistematização das características dos textos de um gênero também podem contribuir para melhorar a proficiência dos alunos de ensino superior que necessitem produzir textos deste gênero, embora concluam que nem sempre é o caminho suficiente para fazê-lo.

Embora concordemos em alguns pontos quanto às posições adotadas por Coutinho e Miranda (2009), Dolz, Gagnon e Decândio (2010) e Silva e Santos (2011), entre outros autores já mencionados neste capítulo, como Swales (1990), Swales e Feak (1994, 2004, 
2012) e Motta-Roth e Hendges (2010), resolvemos desenvolver nossa própria descrição do gênero artigo científico, diferente em alguns aspectos, mas com o mesmo propósito de ensinar a produção do referido gênero. Em sua elaboração, foram considerados critérios de funcionalidade do artigo científico, cujo principal propósito é o de comunicar os resultados de um estudo ou investigação acadêmica; e de arquitetura textual, ou seja, do conjunto de seções com diferentes objetivos e escolhas linguísticas, variáveis conforme as realizações temáticas da cada área.

Seguem a descrição que utilizamos e algumas observações quanto a variações possíveis, conforme as normas para submissão de diversos periódicos, em virtude de se considerar a real possibilidade de publicação dos artigos a serem produzidos:

\section{CONCEPÇÃO DO GÊNERO ARTIGO CIENTÍFICO}

- Título

- Autores e Instituições a que estão ligados

- Resumo

- Palavras-chave

- Introdução:

Contextualização da pesquisa

Objetivo

Justificativa

- Fundamentação Teórica - relação com o tema do estudo

- Metodologia - procedimentos do estudo

- Resultados e análises

- Conclusão

- Referências

- Título em Inglês e Abstract

- Keywords 
Observa-se ainda que, atualmente, grande parte das revistas científicas pede que a versão em Inglês do Título, do Resumo e das Palavras-chave suceda essas seções em Português. Outra variação pede que Title, Abstract e Keywords venham ao final do artigo. As seções de Fundamentação Teórica, Metodologia e Resultados não precisam necessariamente acompanhar essa nomenclatura, podendo seus títulos serem relacionados às realizações temáticas expressas no artigo.

Justificamos a validade de nossa descrição por considerá-la mais detalhada e adaptável que os modelos encontrados em outros autores. Além disso, tendo apresentado tal concepção nas duas aplicações de nossa proposta de produção textual como modelo passível de alterações conforme audiência ou área de estudo, verificamos que ela se mostrou bastante adequada e contribuiu para orientar as produções dos alunos.

Ao admitir atualizações e prever a possibilidade de redirecionamento das atividades conforme os resultados obtidos em cada etapa do processo, essa concepção de artigo científico articula-se ao procedimento didático de práticas sequenciadas denominado Sequências Didáticas. Descritas por Dolz, Noverraz, e Schneuwly (2004, p. 83) como um meio de "dar acesso aos alunos a práticas de linguagem novas ou dificilmente domináveis"; tal procedimento foi adotado por assumirmos sua adequação ao ensino de produção textual com base em gêneros, como veremos a seguir.

\subsubsection{O gênero artigo científico e as Sequências Didáticas}

Ao situar os gêneros textuais na sala de aula, Marcuschi (2008, p. 211) cita Dolz e Schneuwly como autores que se preocupam tanto com o ensino da escrita como da oralidade. Marcuschi afirma que esses autores são conhecidos aqui no Brasil principalmente pela metodologia utilizada para construir as sequências didáticas, por meio das quais abordam o ensino de gêneros textuais orais e escritos. Para esta pesquisa, interessam-nos principalmente os conceitos de gênero, de gênero como instrumento didático e as maneiras e princípios de estruturação das sequências didáticas desenvolvidas por Dolz, Schneuwly, juntamente a seus colegas do grupo de pesquisa da Universidade de Genebra, instituição da qual fazem parte.

Quanto ao conceito de gêneros, Schneuwly (2004), em artigo dedicado ao estudo de gêneros e tipos de discurso, cita e adota as noções de Bakhtin já referidas anteriormente: 
- cada esfera de troca social elabora tipos relativamente estáveis de enunciados: os gêneros;

- três elementos os caracterizam: conteúdo temático - estilo - construção composicional;

- a escolha de um gênero se determina pela esfera, as necessidades da temática, o conjunto dos participantes e a vontade enunciativa ou intenção do locutor. (2004, p. 23)

Em estudo contemporâneo, Schneuwly e Dolz (2004, p. 64), ao abordar questões de aprendizagem de linguagem, afirmam que ela se dá, precisamente, "no espaço situado entre as práticas e as atividades de linguagem", lugar esse em que são produzidas transformações sucessivas da atividade do aprendiz, que conduzem à construção das práticas de linguagem. $\mathrm{O}$ gênero, por atravessar a heterogeneidade das práticas de linguagem e fazer emergir uma série de regularidades no uso linguístico, constitui um termo de referência intermediário para a aprendizagem, podendo ser considerado um "megainstrumento que fornece um suporte para a atividade, nas situações de comunicação, e uma referência para aprendizes. " (SCHNEUWLY e DOLZ, 2004, p. 64)

Ainda em Schneuwly e Dolz (2004, p. 70), encontramos uma teorização do processo didático do ensino de gêneros que compreende três princípios em forte interação e perpétuo movimento: legitimidade, referindo-se aos saberes teóricos; pertinência, referindo-se às capacidades dos alunos, aos objetivos da escola e aos processos de ensino-aprendizagem; e solidarização, para tornar coerentes os saberes em função dos objetivos. A imbricação dos três princípios "constitui uma das dimensões da formação do objeto escolar, definido por sua modalização didática". (2004, p. 70) Nesse sentido, para "explicitar o conhecimento implícito do gênero", esses autores propõem a elaboração de "modelos didáticos de gêneros", que apresentariam, em resumo, duas principais características: 1) constituir uma síntese com objetivo prático para orientar as intervenções dos professores; 2) evidenciar as dimensões ensináveis do gênero, com base nas quais diversas sequências didáticas podem ser concebidas. (SCHNEUWLY e DOLZ, 2004, p. 70)

Ainda sobre o tema dos gêneros, Dolz, Noverraz e Schneuwly (2004) afirmam que os textos escritos ou orais que produzimos quando nos comunicamos são diferentes entre si, porque tal produção acontece em condições diferentes, o que pede uma adaptação. Todavia, apesar da diversidade, é possível constatar regularidades: em situações semelhantes, produzimos textos semelhantes - os gêneros de textos -, reconhecidos por todos, o que facilita a comunicação. Os autores citam como exemplos gêneros da modalidade escrita uma carta de solicitação, um conto; e da oral, uma exposição diante de uma sala de aula, uma conversa à 
mesa com amigos ou a família, salientando que alguns gêneros interessam mais à escola do que outros. (DOLZ, NOVERRAZ, e SCHNEUWLY, 2004, p. 83)

Ao tratar desse interesse que a escola tem em determinados gêneros, Dolz e Schneuwly (2004, p. 48) propõem um agrupamento de gêneros para fins didáticos, embora reconheçam que os limites entre um grupo e outro não sejam estanques. Arriscamos dizer que, embora não esteja relacionado em tal agrupamento, provavelmente por ser utilizado apenas no ensino superior e não no ensino fundamental, foco desses autores, o gênero artigo científico poderia estar entre aqueles cujos "Domínios sociais de comunicação" fossem "Transmissão e construção de saberes"; o "Aspecto tipológico" fosse "Expor"; e as "Capacidades de linguagem dominantes" fossem "Apresentação textual de diferentes formas dos saberes.

Concordamos com Dolz e Schneuwly (2004, p. 43) quando eles explicitam, como postulado fundamental de seu trabalho, o fato de que "comunicar-se oralmente ou por escrito pode e deve ser ensinado sistematicamente" e estabelecem que a concepção de conjunto do trabalho que propõem se articula por meio de uma estratégia chamada sequência didática, adequada tanto para a produção oral quanto a escrita, que consistiria de uma "sequência de módulos de ensino, organizados conjuntamente para melhorar uma determinada prática de linguagem." Tais procedimentos instauram "uma primeira relação entre um projeto de apropriação de uma prática de linguagem e os instrumentos que facilitam essa apropriação." (grifo dos autores) (DOLZ e SCHNEUWLY, 2004, p. 43)

Em artigo em coautoria com Noverraz (2004, p. 82), em que Dolz e Schneuwly se propõem especificamente a apresentar o procedimento das sequências didáticas para o oral e a escrita, os autores apresentam uma definição bastante semelhante, apenas um pouco ampliada: "Uma 'sequência didática' é um conjunto de atividades escolares organizadas, de maneira sistemática, em torno de um gênero textual oral ou escrito." (DOLZ, NOVERRAZ, e SCHNEUWLY, 2004, p. 82)

Segundo esses autores, a finalidade da sequência didática é "dar acesso aos alunos a práticas de linguagem novas ou dificilmente domináveis" (2004, p. 83), ou seja, esse conjunto de atividades organizadas em torno de um gênero que o aluno não domina, ou o faz ineficientemente, tem por objetivo que ele possa escrever ou falar de modo mais adequado em determinada situação de comunicação, ajudando-o a dominar melhor um gênero de texto. Resumidamente, Dolz, Noverraz e Schneuwly (2004) assim descrevem a sequência didática: 
elaboram um primeiro texto inicial, oral ou escrito, que corresponde ao gênero trabalhado; é a primeira produção. Essa etapa permite ao professor avaliar as capacidades já adquiridas e ajustar as atividades e os exercícios previstos na sequência às possibilidades e dificuldades reais de uma turma. Além disso, ela define o significado de uma sequência para o aluno, isto é, as capacidades que deve desenvolver para melhor dominar o gênero de texto em questão. Os módulos, constituídos por várias atividades ou exercícios, dão-lhe os instrumentos necessários para esse domínio, pois os problemas colocados pelo gênero são trabalhados de maneira sistemática e aprofundada. No momento da produção final, o aluno pode pôr em prática os conhecimentos adquiridos e, com o professor, medir os progressos alcançados. A produção final serve, também, para uma avaliação de tipo somativo, que incidirá sobre os aspectos trabalhados durante a sequência. (DOLZ, NOVERRAZ, e SCHNEUWLY, 2004, p. 84)

Ainda conforme se pode encontrar em Dolz, Noverraz e Schneuwly (2004, p. 83), o esquema a seguir representa a estrutura base de uma sequência didática:
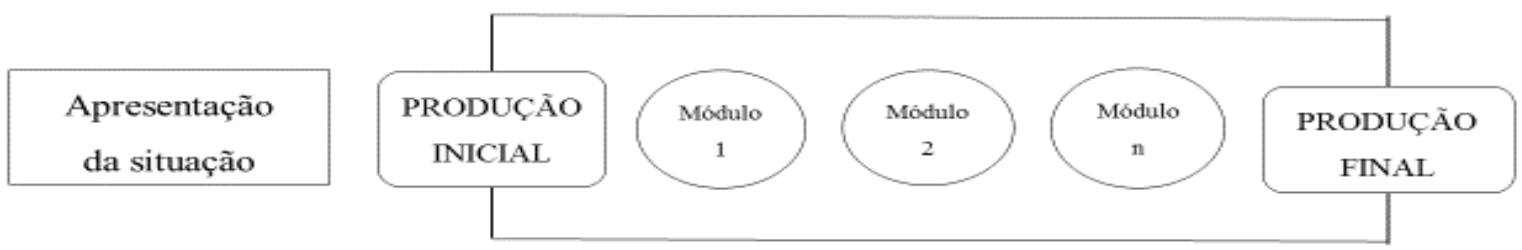

Figura 5: Esquema da Sequência Didática (Em Dolz, Noverraz e Schneuwly, 2004, p. 83).

Dolz, Noverraz e Schneuwly (2004, p. 91) acrescentam que, para melhor compreensão e apreciação do procedimento da Sequência Didática, ou SD como a referiremos daqui em diante, é necessário conhecer um pouco mais sobre os princípios teóricos que a nortearam, seu caráter modular, as diferenças entre sua aplicação na oralidade e na escrita e a articulação entre a sequência e outros domínios do ensino da língua. Procede-se, a seguir, a um detalhamento das escolhas pedagógicas, psicológicas e linguísticas que orientaram a elaboração do procedimento da Sequência Didática e suas principais finalidades, já que, não por coincidência, a decisão deste estudo em apresentar o ensino de produção do artigo científico por meio da SD tem por base a concordância com tais princípios. 
Entre os fundamentos teóricos do procedimento da sequência didática, algumas escolhas pedagógicas incluem a possibilidade de avaliação formativa para a regulação dos processos de ensino e aprendizagem, isto é, um processo avaliativo que detecte o problema particular de cada aluno e oriente-o ao procedimento adequado ${ }^{45}$. Segundo Dolz, Noverraz e Schneuwly (2004, p. 92), ao utilizar a SD, também se opta pela motivação dos alunos a, de fato, escrever e falar, e ainda por maximizar as chances de cada aluno se apropriar dos instrumentos e noções propostas, pela diversificação das atividades e exercícios. No que diz respeito ao presente estudo, pretende-se que essa maximização das possibilidades de apropriação do objeto de estudo seja significativamente ampliada pelo fato de se oferecerem atividades em ambientes presenciais e virtuais, de modo planejado e adequado às funcionalidades de cada meio.

As escolhas psicológicas (terminologia dos autores) que guiam a SD incluem a atividade de produção de textos escritos ou orais por meio da representação da situação de comunicação, além do trabalho sobre conteúdo e estruturação textual e a transformação do modo de falar e de escrever do aluno por meio da formação de uma consciência mais ampla do seu comportamento de linguagem. Para tanto, propõe-se o uso de diferentes instrumentos de linguagem, como formas particulares de argumentação, que possam ampliar seu domínio linguístico e discursivo. Em termos de atividades de linguagem, a SD escolhe instrumentos linguísticos que permitam compreender as unidades textuais e discursivas produzidas. A língua é abordada em seu funcionamento diversificado, adaptando-se às situações de comunicação, sendo que os gêneros de texto, "formas históricas relativamente estáveis de comunicação" constituem o objeto da SD, pois definem o que dizer, por meio de quais estruturas textuais e com quais meios linguísticos. (DOLZ, NOVERRAZ e SCHNEUWLY, 2004, p. 92)

Conforme esses autores, as finalidades gerais do procedimento da SD são: oferecer aos alunos instrumentos precisos e eficazes para melhorar suas capacidades de escrever e falar, preparando-os para dominar sua língua nas diversas situações cotidianas de comunicação; desenvolver uma relação consciente e voluntária entre o aluno e seu comportamento linguístico, favorecendo a avaliação formativa e a autorregulação; construir a representação

${ }^{45}$ Conforme Perrenoud (1999, p. 78), avaliação formativa pode ser definida como "toda prática de avaliação contínua que pretenda melhorar as aprendizagens em curso, contribuindo para o acompanhamento e orientação dos alunos durante todo o seu processo de formação. É formativa toda a avaliação que ajuda o aluno a aprender e a se desenvolver, que participa da regulação das aprendizagens e do desenvolvimento no sentido de um projeto educativo". 
das atividades de escrever e falar em situações complexas como produto de um trabalho de elaboração lento e cuidadoso.

Dolz, Noverraz e Schneuwly (2004, p. 93) afirmam que a característica geral de modularidade das SD ressalta os processos de observação e descoberta inscritos numa perspectiva construtivista, interacionista e social, com atividades intencionais que devem ser estruturadas e intensificadas de maneira a adaptarem-se às necessidades particulares de cada grupo de aprendizes. Desse modo, a modularidade associa-se à diferenciação pedagógica, tratando a heterogeneidade entre os estudantes como fator de enriquecimento, ao invés de obstáculo ao processo, ao selecionar, adaptar e transformar atividades em função das necessidades dos alunos, de sua história didática.

Uma observação pormenorizada da produção inicial dos alunos auxilia o professor a adaptar a SD à sua turma, exigindo que ele analise tais produções conforme os objetivos daquela sequência em particular e das características do gênero estudado. Conforme os resultados, são escolhidas atividades adequadas à continuação do procedimento e, nos casos de maior dificuldade, providenciadas intervenções profundas e diferenciadas, conforme os problemas detectados. (DOLZ, NOVERRAZ e SCHNEUWLY, 2004, p. 94)

Dado o fato de que, no texto escrito, em geral o processo de produção e o produto final ocorrem separadamente (exceto nas interações escritas diretas, como nos chats da internet, por exemplo), o autor pode considerar sua produção textual um objeto a ser trabalhado, revisto, reescrito até a versão final apresentada ao leitor. Concordamos integralmente com Dolz, Noverraz e Schneuwly (2004, p. 95), quando esses pesquisadores dizem que um objetivo fundamental do ensino de escrita é considerar o próprio texto um objeto a ser retrabalhado, pois, segundo eles, "escrever é (também) reescrever".

Segundo os autores, as sequências constituem um lugar de intersecção entre atividades de expressão e de estruturação que têm como objetivo aperfeiçoar as práticas de escrita e de produção oral e são centradas em aquisição de procedimentos e práticas. Ainda assim, as SD, conforme advertem Dolz, Noverraz e Schneuwly (2004, p. 96), "não podem assumir a totalidade do trabalho necessário para levar os alunos a um melhor domínio da língua e devem apoiar-se em certos conhecimentos, construídos em outros momentos. " Esses pesquisadores citam como abordagens complementares, que se articulam ao trabalho proposto com as sequências, questões mais particulares de textualização, como o emprego de tempos verbais e discursos indiretos, bem como questões de gramática, sintaxe e ortografia, que também devem ser consideradas. 
Complementando todas essas observações teóricas e metodológicas sobre as Sequências Didáticas, cumpre ressaltar que, apesar de os estudos ligados a elas terem sido desenvolvidos inicialmente por pesquisadores da Didática do Francês na Universidade de Genebra, entre eles os renomados professores Bernard Schneuwly e Joaquim Dolz, muitas transposições e adaptações de suas ideias já têm sido feitas aqui no Brasil, seja na edição dos PCN (Parâmetros Curriculares Nacionais) em 1997, que já previam esse tipo de estudo e de atividades sequenciadas, seja em Dolz, Gagnon e Decândio (2010), Machado, Lousada e Abreu-Tardelli, (2004, 2007, 2009, 2010), entre diversos outros.

Segundo Machado e Cristóvão (2006, p. 552), a elaboração das primeiras Sequências Didáticas aconteceu na tentativa de solucionar problemas de transposição didática, que seriam “o conjunto das transformações que um determinado conjunto de conhecimentos necessariamente sofre, quando temos o objetivo de ensiná-lo, trazendo sempre deslocamentos, rupturas e transformações diversas a esses conhecimentos. "Há três níveis básicos de transposição, do conhecimento científico ao conhecimento a ser ensinado, desse para o conhecimento efetivamente ensinado e desse último para o conhecimento efetivamente aprendido.

Um exemplo de problema que pode ocorrer em relação à transposição didática já vem acontecendo no Brasil desde elaboração dos PCN de LP (Parâmetros Curriculares Nacionais de Língua Portuguesa) de quinta a oitava séries, documentos que determinam o que pode ser considerado como objeto a ser ensinado, dentre os inúmeros objetos do conhecimento científico, uma seleção que sofre o controle social pelas autoridades e pelos especialistas que ajudaram a elaborar tais documentos. Nesse primeiro nível de transposição, a passagem do conhecimento científico para o conhecimento a ser ensinado, surge o problema da seleção dos conteúdos, que leva em conta tanto o conhecimento em si quanto as práticas sociais de linguagem. Entretanto, para ensinar tais práticas, é preciso construir conhecimento sobre elas, um conhecimento que nem sempre está consolidado. (MACHADO e CRISTÓVÃO, 2006, p. $553)$.

Segundo essas autoras, observar esse e outros problemas como a compartimentalização dos conhecimentos no campo do ensino de línguas, fez que, entre 1985 e 1988, os pesquisadores francofones construíssem o conceito da sequência didática para tentar superá-los, pois ela implica uma lógica de descompartimentalização dos conteúdos e capacidades que deveriam englobar as práticas de escrita, de leitura e as práticas orais. A princípio eram Sequências Didáticas abertas a diferentes objetos de conhecimento, só depois, 
na década de 90, começaram a centrar-se no ensino de gêneros textuais, sendo assumidas oficialmente nas instruções oficiais para o ensino de línguas na França em 1996. (p. 554)

Segundo Machado e Cristóvão (2006, p. 555), o interesse pelo procedimento das SD é justificado por muitas razões, a saber: permitiria um trabalho global e integrado; tanto conteúdos oficiais quanto objetivos de aprendizagem específicos seriam considerados em sua construção; a SD contemplaria o trabalho com atividades e suportes variados; permitiria integrar atividades de leitura, de escrita e de conhecimento da língua; facilitaria a construção de programas de continuidade; propiciaria a motivação do estudante ao explicitar os objetivos geral e específico das diferentes atividades.

A proposta de ensino de produção do gênero textual-discursivo artigo científico que este trabalho apresenta no Capítulo 4, a seguir, inspira-se nas já descritas bases da sequência didática, para apresentar um conjunto de atividades destinadas ao ensino de produção do gênero artigo acadêmico, planejadas conforme a funcionalidade dos ambientes em que serão desenvolvidas. Pelos resultados obtidos ao final das aplicações, referendados pelas respostas dos alunos ao questionário que lhes foi proposto (transcritas e analisadas no final do próximo capítulo), acreditamos estar contribuindo para alcançar o objetivo de preparar o aluno de ensino superior, público-alvo desta proposta, para a prática social de se expressar mais adequadamente na situação comunicativa de registrar e transmitir conhecimento científico.

Para tanto, optou-se por planejar a sequência de atividades a serem realizadas, tomando por base o referido estudo da organização retórica e das recorrências linguísticas de algumas seções do artigo científico, como o Resumo, a Introdução e a Conclusão, e de procedimentos como a produção de citações e de referências bibliográficas, conforme proposta de Swales (1990) e Swales e Feak (1994, 2000, 2004, 2012), ressignificada por Motta-Roth e Hendges (2010). De qualquer modo, fica o registro de que a proposta deste trabalho sempre poderá sofrer adaptações e reconstruções por conta do caráter dinâmico do processo educativo com respeito a particularidades contextuais e de audiência.

Em seguida, apresentamos, no Capítulo 4, o planejamento dos encontros, o conjunto de sequências didáticas de aprendizagem combinada em ambientes presenciais e virtuais elaboradas para o ensino de artigo acadêmico, uma análise de atividade e damos voz a alunos para que expressem seu posicionamento. 


\section{CAPÍTULO 4}

\section{$\mathrm{O}$ artigo científico em}

aprendizagem

\section{combinada - sequência}

de atividades 
O planejamento e as sequências de atividades combinadas que compõem esta abordagem do ensino do gênero artigo científico levam em conta fundamentos já mencionados nos capítulos anteriores, como 1) a perspectiva textual-interativa de língua, tomada como atividade sócio-histórica, sociocognitiva e sociointerativa, observando também seu aspecto sistemático, como indica Marcuschi (2008, p. 56); 2) a convicção de que os processos de ensino e aprendizagem só ocorrem efetivamente na interação de professores e alunos com o propósito de construir sentidos e conhecimentos conjuntamente, conforme Fávero, Andrade e Aquino (1998) e Silva (2002); 3) a possibilidade de tirar proveito das diferentes funcionalidades de ambientes presenciais e virtuais de aprendizagem, como postulam Haythornthwaite e Andrews (2011); 4) a combinação de atividades que integram pontos fortes do ensino presencial e virtual na Aprendizagem combinada (Blended learning) proposta por Garrison e Vaughan (2008); 5) o enfoque da linguagem como parte integrante da cognição, segundo a Linguística Cognitiva de Silva (2004); 6) e o exame das conexões mentais que ocorrem com o uso da linguagem e seus efeitos em diferentes contextos, conforme a Teoria da Mesclagem Conceitual de Fauconnier e Turner (2002).

Neste capítulo, encontra-se o planejamento das aulas que compõem a referida proposta, seguido do detalhamento das sequências de atividades planejadas para três momentos que consideramos fundamentais no ensino de produção de artigo científico: o Resumo, a Introdução e os Resultados/Discussão/Conclusão. Ao planejar esse conjunto de práticas, levamos em consideração a relação dos indivíduos entre si e com a situação discursiva, aspecto central no processo interlocutivo, de acordo com a visão sociointerativa de Marcuschi (2008, p. 77). Tal perspectiva demandará dos "novos" autores que, ao escreverem, tenham em mente seus interlocutores, já que a atividade de produzir textos não é unilateral, pois envolve enunciar conteúdos e sugerir sentidos "que devem ser construídos, inferidos, determinados mutuamente".

Escolhemos realizar as atividades constituintes de cada sequência em um determinado ambiente de aprendizagem, presencial ou virtual, e isso se justifica por conta das funcionalidades de cada um desses meios. Além disso, as práticas descritas estão relacionadas às indicações de um corpus de consulta, constituído de artigos que podem ser acessados por meio de links, pois se trata de textos já publicados em meio eletrônico. No ANEXO A deste trabalho, encontra-se a lista de tais links, um material que também é disponibilizado aos alunos durante os cursos. Como tal proposta de atividades já foi aplicada pelo menos em duas 
ocasiões, para turmas de Estatística e de Letras, as indicações de textos para leitura referem-se a ambas as áreas.

Apresentamos também a reprodução de uma tarefa comentada e reescrita, com a análise das implicações cognitivas de sua realização, com o propósito de examinar como essa intervenção contribuiu para a construção de conhecimento por parte do aluno. Ao final do capítulo, encontra-se a transcrição de uma pesquisa realizada entre alunos que participaram dessas duas aplicações e seus resultados comentados. Essa pesquisa revela a voz de quem efetivamente participou do processo e, por isso, consideramos de extrema importância inserila.

4.1 Proposta de Aprendizagem Combinada para o ensino de artigo científico

\subsubsection{Plano de trabalho}

Nas duas aplicações desta proposta ${ }^{46}$, o objetivo geral do curso foi desenvolver e aprimorar as competências linguísticas, discursivas e textuais dos participantes para a produção de escrita acadêmica, enquanto o objetivo específico foi produzir um texto integral do gênero artigo científico, com temas escolhidos pelos alunos, dentro de sua área de estudo. Nesse sentido, foram abordadas as diversas seções que compõem o artigo científico, em termos de superestruturas e componentes linguísticos. As aulas que compõem a aplicação da proposta foram planejadas para um curso semestral de quinze encontros semanais, em ambiente presencial, com a duração de cem minutos. Paralelamente, propomos a participação dos alunos nas atividades a serem desenvolvidas em ambiente virtual, por meio de grupos de emails ou de acesso ao ambiente Moodle de aprendizagem.

O planejamento apresentado a seguir na Tabela 2 é constituído de atividades passíveis de serem realizadas nos dois ambientes - e foram efetivamente aplicadas desse modo - e apresenta indicações também passíveis de reformulação de acordo com as necessidades da turma em que são aplicadas. $\mathrm{O}$ fato de combinar atividades face a face e online, e assim

\footnotetext{
${ }^{46}$ Conforme informação retomada da Introdução deste estudo, a primeira aplicação dessa proposta de produção de artigo científico ocorreu no segundo semestre de 2012, na disciplina obrigatória FLC 0474 - Língua Portuguesa no IME-USP, com nossa monitoria. A segunda aconteceu durante o segundo semestre de 2013, na disciplina optativa livre FLC 1261 - Leitura e Produção de textos II, na FFLCH-USP, lecionada pela Profa. Dra. Zilda Gaspar Oliveira de Aquino, com nossa monitoria no ambiente virtual de aprendizagem.
} 
ampliar as possibilidades de interação, permite que se identifiquem questões a serem revistas ou aprofundadas, num movimento de constante avaliação do andamento do curso. A Tabela 2 apresenta, na primeira coluna, o número de encontros. A coluna do meio corresponde às atividades realizadas em ambientes presenciais e a terceira coluna é indicativa das atividades desenvolvidas virtualmente. Observamos que as atividades não ocorrem concomitantemente e, além disso, ressaltamos que a interação virtual não tem um número exato de vezes para ocorrer, é livre.

Tabela 2 - Plano de curso

\begin{tabular}{|c|c|c|}
\hline Encontros & Ambiente presencial & Ambiente virtual \\
\hline $1^{\circ}$ & $\begin{array}{l}\text { Apresentações. Discussão sobre o programa, os } \\
\text { objetivos do curso e a expectativa dos } \\
\text { participantes. Instruções para a inserção dos } \\
\text { alunos no ambiente virtual. }\end{array}$ & $\begin{array}{l}\text { Instruções para a utilização de Fórum de } \\
\text { notícias, mensagens e postagens de atividades. } \\
\text { Postagem do Programa do curso, calendário, } \\
\text { critérios de avaliação e de links a artigos do } \\
\text { corpus de consulta. }\end{array}$ \\
\hline $2^{\circ}$ & $\begin{array}{l}\text { Discussão sobre escolha de temas. Considerações } \\
\text { sobre escrita acadêmica e Retórica geral das } \\
\text { seções do artigo científico, segundo Swales e } \\
\text { Feak (2004). Início da Sequência Didática para a } \\
\text { produção de Resumo, com a Produção de Leitura } \\
\text { e Observação de Resumos de artigos do corpus } \\
\text { de consulta. }\end{array}$ & $\begin{array}{l}\text { Abertura de tópico no Fórum de discussões e } \\
\text { envio de mensagens para discutir } \\
\text { individualmente os temas escolhidos pelos } \\
\text { alunos por meio de comentários e orientações } \\
\text { bibliográficas. }\end{array}$ \\
\hline $3^{\circ}$ & 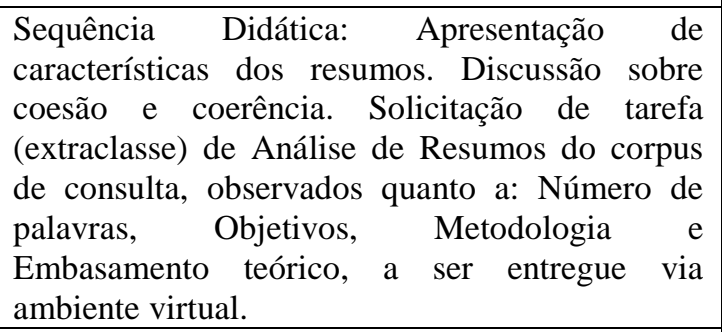 & $\begin{array}{l}\text { Recebimento de tarefas de análise de } \\
\text { Resumos. Devolutiva de comentários } \\
\text { individuais. Postagem de Pauta de Revisão da } \\
\text { tarefa Resumos, com observações sobre } \\
\text { adequações e inadequações recorrentes. }\end{array}$ \\
\hline $4^{\circ}$. & $\begin{array}{l}\text { Sequência Didática: Discussão da Pauta de } \\
\text { Revisão de tarefas com aprofundamento das } \\
\text { questões que provocaram dúvidas. Revisão sobre } \\
\text { Pontuação. Solicitação de tarefa (extraclasse): } \\
\text { Produção de um Resumo para o artigo científico } \\
\text { que pretendem escrever, a ser entregue via } \\
\text { ambiente virtual. }\end{array}$ & $\begin{array}{l}\text { Recebimento de tarefas de Produção de } \\
\text { Resumo. Devolutiva de comentários } \\
\text { individuais. Postagem de uma Pauta de } \\
\text { Revisão da tarefa Resumos, com observações } \\
\text { sobre adequações e inadequações recorrentes. }\end{array}$ \\
\hline $5^{\circ}$ & $\begin{array}{l}\text { Sequência Didática: Discussão da Pauta de } \\
\text { Revisão da produção de Resumo, com } \\
\text { aprofundamento das questões que provocaram } \\
\text { dúvidas. Início da Sequência Didática para a } \\
\text { produção de Introdução com leitura de uma } \\
\text { Introdução de artigo do corpus de consulta e } \\
\text { discussão em grupo. Solicitação de tarefa } \\
\text { (extraclasse): Reescrita final do Resumo, a ser } \\
\text { entregue via ambiente virtual. }\end{array}$ & $\begin{array}{l}\text { Recebimento de tarefas de Reescrita do } \\
\text { Resumo. }\end{array}$ \\
\hline $6^{\circ}$ & $\begin{array}{l}\text { Sequência Didática: Apresentação e discussão de } \\
\text { características da Introdução segundo o Modelo } \\
\text { CARS (SWALES e FEAK, 2004). Discussão: } \\
\text { uso de diacríticos. Solicitação de tarefa } \\
\text { (extraclasse) de leitura e observação das } \\
\text { Introduções de artigos do corpus de consulta } \\
\text { quanto ao Modelo CARS, a ser entregue via } \\
\text { ambiente virtual. }\end{array}$ & $\begin{array}{l}\text { Recebimento de tarefas de leitura e observação } \\
\text { das Introduções quanto ao Modelo CARS. } \\
\text { Devolutiva de comentários individuais. } \\
\text { Postagem de Pauta de Revisão da tarefa de } \\
\text { leitura de Introduções, com observações sobre } \\
\text { adequações e inadequações recorrentes. } \\
\text { Postagem de link para a página da Academia } \\
\text { Brasileira de Letras, busca no VOLP. }\end{array}$ \\
\hline
\end{tabular}




\begin{tabular}{|c|c|c|}
\hline $7^{0}$ & $\begin{array}{l}\text { Sequência Didática: Discussão da Pauta de } \\
\text { revisão da tarefa de leitura de Introduções, com } \\
\text { aprofundamento das questões que provocaram } \\
\text { dúvidas. Abordagem da produção de Citações e } \\
\text { Paráfrases, por meio de leitura e observação de } \\
\text { textos do corpus de consulta e da produção de } \\
\text { uma paráfrase. Solicitação de tarefa (extraclasse) } \\
\text { de produção de uma Introdução para o artigo } \\
\text { científico, a ser entregue via ambiente virtual. }\end{array}$ & $\begin{array}{l}\text { Recebimento de tarefas de produção de uma } \\
\text { Introdução para o artigo científico. Devolutiva } \\
\text { de comentários individuais. Postagem de Pauta } \\
\text { de Revisão da tarefa de produção de } \\
\text { Introduções, com observações sobre } \\
\text { adequações e inadequações recorrentes. }\end{array}$ \\
\hline $8^{\circ}$ & $\begin{array}{l}\text { Sequência Didática: discussão da Pauta de } \\
\text { Revisão da tarefa de produção de Introduções, } \\
\text { com observações sobre adequações e } \\
\text { inadequações recorrentes. Abordagem da questão } \\
\text { das "Normas para configuração de artigos" e } \\
\text { suas possíveis variações por meio da leitura de } \\
\text { alguns documentos disponíveis elaborados por } \\
\text { associações de normas técnicas, instituições e } \\
\text { periódicos de publicação. Discussão sobre o } \\
\text { estabelecimento de Orientações para a produção } \\
\text { do artigo científico a ser entregue para a } \\
\text { avaliação do curso. Solicitação de Reescrita final } \\
\text { (extraclasse) da produção da Introdução, para ser } \\
\text { entregue via ambiente virtual. }\end{array}$ & $\begin{array}{l}\text { Recebimento de tarefas de Reescrita final da } \\
\text { Introdução. Postagem das Orientações para a } \\
\text { produção do artigo científico a ser entregue } \\
\text { para a avaliação do curso. Abertura de Tópico } \\
\text { no Fórum de Discussões para que comentários } \\
\text { e dúvidas sobre as Orientações sejam } \\
\text { colocados, comentados e respondidos pelos } \\
\text { participantes. }\end{array}$ \\
\hline $9^{\circ}$ & $\begin{array}{l}\text { Sequência Didática: atividade em grupo de } \\
\text { leitura e observação em artigos do corpus de } \\
\text { consulta de seções de Desenvolvimento de } \\
\text { artigos científicos. Abordagem da produção de } \\
\text { Referências Bibliográficas por meio do exame de } \\
\text { Referências presentes nos artigos do corpus de } \\
\text { consulta. Atividade de produção de Referências } \\
\text { conforme Orientações de configuração de artigos } \\
\text { adotadas. Solicitação de tarefa (extraclasse) de } \\
\text { produção de Desenvolvimento do artigo, para ser } \\
\text { entregue via ambiente virtual. }\end{array}$ & $\begin{array}{l}\text { Recebimento de tarefas de produção de } \\
\text { Desenvolvimento. Devolutiva de comentários } \\
\text { individuais. Postagem de Pauta de Revisão da } \\
\text { tarefa de produção de Desenvolvimento com } \\
\text { observações sobre adequações e inadequações } \\
\text { recorrentes. Indicação de recursos existentes } \\
\text { em ambientes virtuais de busca (como o } \\
\text { Google Acadêmico) em que é possível } \\
\text { visualizar várias versões de referências } \\
\text { bibliográficas. }\end{array}$ \\
\hline $10^{\circ}$ & $\begin{array}{l}\text { Sequência Didática: discussão da Pauta de } \\
\text { Revisão da tarefa de produção de } \\
\text { Desenvolvimento, com observações sobre } \\
\text { adequações e inadequações recorrentes. Início da } \\
\text { Sequência Didática para a produção das seções } \\
\text { de Apresentação de Resultados, Discussão e } \\
\text { Conclusão: leitura e observação dessas seções } \\
\text { em artigos do corpus de consulta. Discussão } \\
\text { sobre a produção do título principal do artigo e } \\
\text { dos títulos de todas as seções. Solicitação de } \\
\text { tarefas (extraclasse): Reescrita final do } \\
\text { Desenvolvimento e produção de um título para o } \\
\text { artigo, para serem entregues via ambiente virtual. }\end{array}$ & $\begin{array}{l}\text { Recebimento de tarefas: Reescrita final do } \\
\text { Desenvolvimento e produção do título. } \\
\text { Devolutiva de comentários individuais. }\end{array}$ \\
\hline $11^{\circ}$ & $\begin{array}{l}\begin{array}{l}\text { Sequência Didática: } \\
\text { movimentos retóricos entação de de cacterísticas }\end{array} \\
\text { linguísticas das seções de Resultados, Discussão } \\
\text { e Conclusão, segundo Motta-Roth e Hendges } \\
\text { (2010). Solicitação de tarefa (extraclasse): } \\
\text { Análise das seções de Resultados, Discussão e } \\
\text { Conclusão quanto aos Movimentos Retóricos e } \\
\text { características linguísticas em artigos do corpus } \\
\text { de consulta, para ser entregue via ambiente } \\
\text { virtual. }\end{array}$ & $\begin{array}{l}\text { Recebimento de tarefas com a análise das } \\
\text { seções de Resultados, Discussão e Conclusão. } \\
\text { Devolutiva de comentários individuais. } \\
\text { Postagem de uma Pauta de Revisão com } \\
\text { observações sobre adequações e inadequações } \\
\text { recorrentes. }\end{array}$ \\
\hline
\end{tabular}




\begin{tabular}{|c|c|c|}
\hline $12^{\circ}$ & $\begin{array}{l}\text { Sequência Didática: discussão da Pauta de } \\
\text { Revisão da tarefa de análise das seções de } \\
\text { Resultados, Discussão e Conclusão. Abordagem } \\
\text { da questão da Persuasão no discurso acadêmico. } \\
\text { Solicitação de tarefa (extraclasse): produção das } \\
\text { seções de Resultados, Discussão e Conclusão do } \\
\text { Artigo Científico, para ser entregue via ambiente } \\
\text { virtual. }\end{array}$ & $\begin{array}{l}\text { Recebimento de tarefas com a produção das } \\
\text { seções de Resultados, Discussão e Conclusão } \\
\text { do Artigo Científico. Devolutiva de } \\
\text { comentários individuais. Postagem de Pauta de } \\
\text { Revisão com observações sobre adequações e } \\
\text { inadequações recorrentes. }\end{array}$ \\
\hline $13^{\circ}$ & $\begin{array}{l}\text { Sequência Didática: discussão da Pauta de } \\
\text { Revisão da tarefa de produção das Seções de } \\
\text { Resultados, Discussão e Conclusão, com } \\
\text { observações sobre adequações e inadequações } \\
\text { recorrentes. Atendimento individual para sanar } \\
\text { dúvidas sobre as produções. Solicitação de tarefa } \\
\text { (extraclasse): Reescrita final do Artigo } \\
\text { Científico, para ser entregue via ambiente virtual. }\end{array}$ & $\begin{array}{l}\text { Troca de mensagens para esclarecimento de } \\
\text { dúvidas. Recebimento da produção final do } \\
\text { artigo científico para avaliação. }\end{array}$ \\
\hline $14^{\circ}$ & $\begin{array}{l}\text { Atendimento individual para sanar dúvidas sobre } \\
\text { as produções finais. }\end{array}$ & $\begin{array}{l}\text { Recebimento da produção final do artigo } \\
\text { científico para avaliação. }\end{array}$ \\
\hline $15^{\circ}$ & $\begin{array}{l}\text { Orientações finais e avaliação dos resultados do } \\
\text { curso pelo ponto de vista do professor, do } \\
\text { monitor e dos alunos. }\end{array}$ & $\begin{array}{l}\text { Abertura de tópico no Fórum de Discussões } \\
\text { para que os participantes avaliem o curso. }\end{array}$ \\
\hline
\end{tabular}

4.1.2 Práticas adaptadas às funcionalidades dos ambientes

As práticas pedagógicas desenvolvidas durante as aplicações da presente proposta, incluindo as Sequências Didáticas, foram planejadas para se realizarem em determinado ambiente de aprendizagem, presencial ou virtual, por conta das funcionalidades de cada um desses meios, conforme a perspectiva de Haythornthwaite e Andrews (2011). Justificamos a seguir a escolha do ambiente em que foi realizada cada atividade, pela relação de adequação entre a natureza da atividade e a funcionalidade do ambiente.

Após contatos iniciais entre o professor e seus alunos, inicia-se uma fase de orientação sobre a escolha de temas sobre os quais se produzirá o artigo científico. Embora essa etapa seja considerada fundamental para autores como Severino (2007), que propõe diversas técnicas de leitura, síntese textual, documentação bibliográfica com o intuito de preparar o estudante para a investigação científica, a definição de temas não será abordada minuciosamente neste estudo, por não ser esse seu principal objetivo. Além disso, os alunos que participaram dessas duas aplicações, uma turma de Estatística e outra de Letras, já tinham áreas de pesquisa razoavelmente definidas, o que nos levou a optar por um questionamento geral sobre os temas já escolhidos e, quando necessário, uma orientação individual mais específica para os que ainda não haviam se decidido. 
A atividade presencial de questionar aos alunos sobre seus temas de pesquisa pode ser positiva para aqueles que já estão decididos ou aqueles que espontaneamente colocam suas dúvidas, mas a funcionalidade de quase anonimato do ambiente virtual de aprendizagem, indicada por Haythornthwaite e Andrews (2011, p. 14), pode incentivar a interação com os mais tímidos, preocupados com o julgamento alheio sobre sua participação, proporcionando oportunidade para uma orientação mais particular. Em seguida à escolha dos temas, para que obtenham uma visão geral da estruturação do texto que têm como objetivo produzir, é apresentado aos alunos e comentado o esquema da retórica geral das seções do artigo científico, de Swales e Feak (2004, p. 222), conforme Figura $3^{47}$, retomada do Capítulo 3:

Introduçào (I)
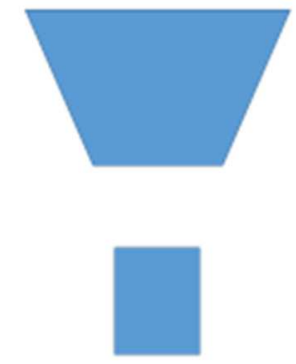

Materiais (M)

Resultados (R)

Discussào (D)
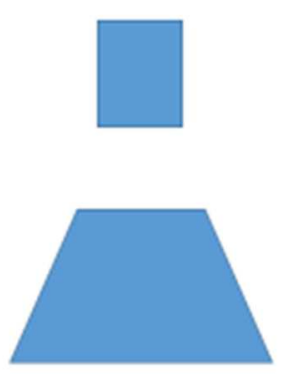

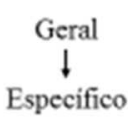

Especifico
$\downarrow$
Geral

Figura 3 - Formato geral de um artigo científico (SWALES e FEAK, 2004, p. 222)

Essa atividade é realizada em ambiente presencial pela funcionalidade deste em reunir face a face professor e alunos e, como consequência, facilitar a detecção de dúvidas em relação à teoria mencionada, conforme a interação ocorrida. Em complementação, apresentam-se ainda as considerações sobre a escrita acadêmica, também em ambiente presencial, conforme a Figura $2^{48}$, retomada do Capítulo 3, a seguir, referente à proposta de

${ }^{47}$ A Figura "Formato geral de um artigo científico (SWALES e FEAK, 2004, p. 222)" já foi referida no Capítulo 3 com a numeração "Figura 3", portanto optamos por retomá-la com a mesma numeração, visto tratar-se da mesma figura.

${ }^{48}$ A Figura "Considerações sobre escrita acadêmica (SWALES e FEAK, 2012, p. 3) já foi referida no Capítulo 3 com a numeração "Figura 2", portanto optamos por retomá-la com a mesma numeração, visto tratar-se da mesma figura. 
Swales e Feak (2012, p. 1), que relaciona audiência, objetivo, organização, estilo, fluxo e apresentação.

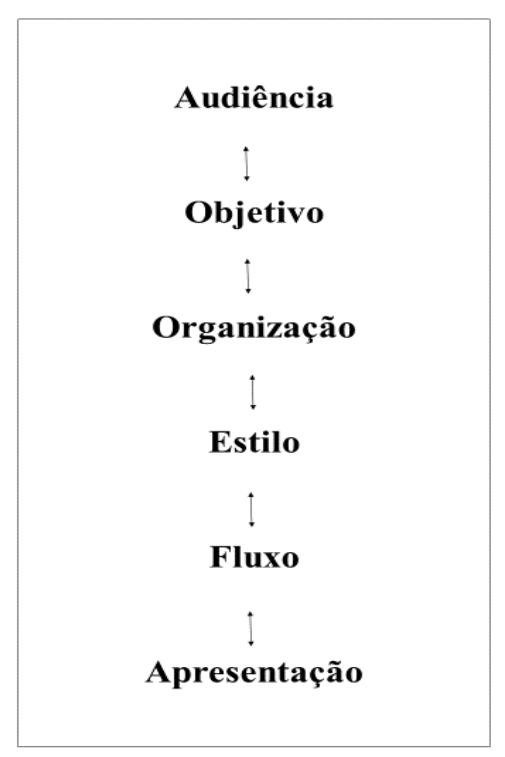

Figura 2 - Considerações sobre escrita acadêmica (SWALES e FEAK, 2012, p. 3)

Após leitura e discussão sobre tais considerações, com ênfase na preocupação com a audiência, o que influencia as demais, iniciam-se as atividades de produção propriamente dita presentes na Sequência Didática para a Produção do Resumo, conforme a Figura 6, mais adiante. Optamos por iniciar o curso sobre produção de artigo científico abordando o Resumo, visto que essa seção contém os elementos centrais do texto integral. De qualquer maneira, ao final da produção do artigo, o Resumo admite revisão, para que expresse de fato a íntegra do estudo que o artigo expressa. Embora tenhamos selecionado apresentar detalhadamente apenas três Sequências Didáticas, ressaltamos nosso interesse pela unidade textual-discursiva, o que nos levou a avaliar o artigo produzido pelos alunos durante o curso como um todo.

\subsubsection{Sequência Didática da Produção do Resumo}

Para comentarmos a Figura 6 a seguir, correspondente à "Sequência Didática da Produção do Resumo", vamos nos reportar à numeração de 1 a 11 que se encontra dentro das formas em azul e que indicam a ordem das atividades realizadas. 
SEQUÊNCIA DIDÁTICA: RESUMO
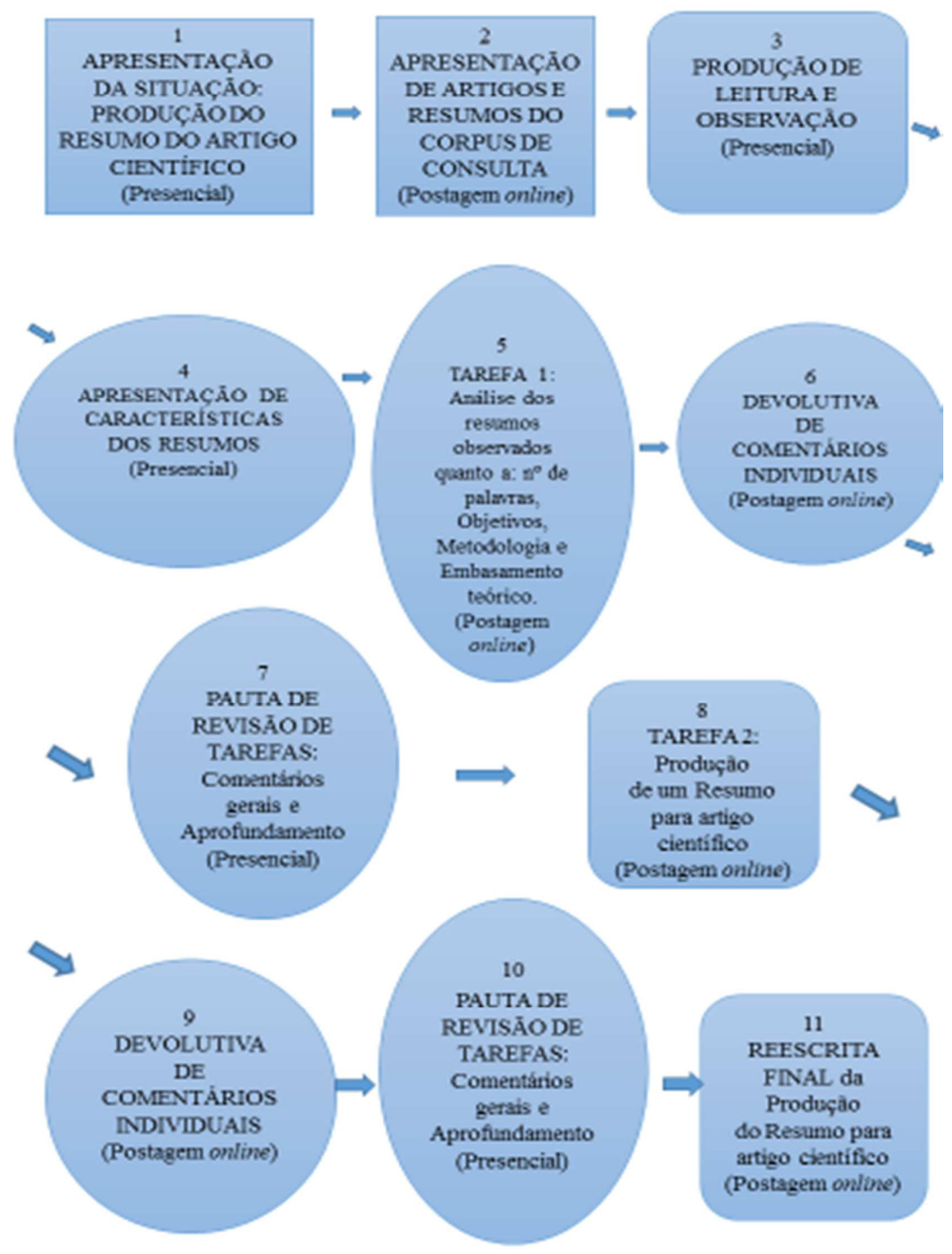

Figura 6 - Sequência Didática da Produção do Resumo 
Para apresentar a situação da Produção do Resumo do artigo científico (cf. 1), é necessário indicar que o também chamado Resumo Acadêmico acompanha textos como o artigo científico, as dissertações e as teses, sintetizando-os com a função de dar ao leitor uma ideia do que ele vai encontrar no texto integral, particularmente no caso de publicação em bibliotecas, acervos digitais e revistas científicas. Além disso, o Resumo também pode ser enviado a organizadores de Congressos, Seminários e outros encontros da comunidade acadêmica para propor a apresentação de um estudo ou pesquisa em tais eventos.

Ambas as funções implicam a observação de normas específicas - como número de palavras e seções obrigatórias - que cada instituição ou periódico de publicação adotam, seja para a produção do texto integral, seja para a produção do resumo. De qualquer modo, em geral, um Resumo deve conter: Justificativa/Objetivo, Perspectiva teórica, Metodologia, Resultados e Conclusão, com variações possíveis de acordo com a área de estudo, o que indica a necessidade de os alunos conhecerem o maior número possível de artigos e resumos da área de pesquisa que escolheram.

A Leitura e a Observação (cf. 3) de artigos do corpus de consulta e seus respectivos resumos (cf. 2), antecedem a Apresentação de Características dos Resumos (cf. 4), para a qual foi utilizada uma adaptação da obra de Motta-Roth e Hendges (2010), indicada nos slides de PowerPoint a seguir.

\section{Um Resumo Acadêmico pode ser construído com as} respostas às seguintes questões:

- Justificativa/Objetivo: Por que e para que o estudo foi realizado?

- Perspectiva teórica: Que conceito(s) é (são) central(is) ao trabalho?

- Metodologia: Como o estudo foi realizado?

- Resultados: Que resultados foram obtidos?

- Conclusão: Qual a significação desses resultados para a área? 


\section{Organização retórica do resumo}

- No artigo de revisão da literatura, o resumo trará os elementos centrais da discussão feita no texto integral, indicando o objetivo de levantar as questões teórico-bibliográficas em estudos que abordam e discutem o tema escolhido.

- No resumo empírico ou experimental, uma ordem possível é:

a) Definir o problema (intenção do autor, tese)

b) Estabelecer objetivo (justificativa, objetivo, diferença de pesquisas prévias)

c) Descrever o método (apresentação dos procedimentos envolvidos)

d) Apresentar resultados (detalhamento de resultados e consequentes inovações para a área)

e) Indicar a conclusão (implicações dos resultados)

Adaptado de MOTTA-ROTH HENDGES, 2010

\section{Características linguísticas do resumo}

Características gerais:

- Verbos no pretérito e no presente do indicativo, $3^{\Perp}$. do singular, voz passiva.

- Linguagem econômica com vocabulário variado, sentenças declarativas simples, sem redundåncias, superlativos, abreviaçóes ou excesso de detalhes.

Marcadores metadiscursivos específicos:

- Definição do problema: Exploraçōes recentes em $x$ indicam $y$; A última década trouxe significativa intensificaçăo no estudo de $x$, entretanto nenhum consenso foi atingido no que concerne a $y$.

- Objetivo: Neste trabalho pretendemos $x$; Este artigo relata/apresenta uma pesquisa sobrex;

- Método: Em primeiro lugar examinaremos $x ; E$ seguida, observaremos $y$;

- Resultados: Os resultados da pesquisa incluem indicaç̋es de $x$;

- Conclusão: As conclusões alcançadas referem-se a $x$; O trabalho argumenta que $x$;

Adaptado de MOTTA-ROTH e HENDGES, 2010

Figura 7 - Slides de PowerPoint: Resumo Acadêmico

No primeiro slide, apresenta-se a possibilidade de construir um Resumo por meio de respostas a questões sobre Justificativa, Objetivo, Metodologia, Resultados e Conclusão. No segundo, aborda-se a produção do Resumo empírico ou experimental sob a perspectiva da sua Organização retórica, sugerindo uma possível ordem de ações. No terceiro slide, trata-se das características linguísticas gerais do Resumo e indicam-se marcadores metadiscursivos específicos para cada ação sugerida no slide anterior. 
Voltando à Sequência Didática (Figura 6), procede-se às atividades relativas à realização da TAREFA 1: Análise dos resumos observados quanto a: $\mathrm{n}^{\circ}$ de palavras, Objetivos, Metodologia e Embasamento teórico (cf. 5), proposta em sala de aula presencial para ser postada online. Também via ambiente virtual, são enviadas as respectivas Devolutivas de comentários individuais (cf. 6) e é elaborada uma PAUTA DE REVISÃO DE TAREFAS: Comentários gerais e Aprofundamento (cf. 7). Esta Pauta é apresentada presencialmente aos alunos, sempre garantindo o anonimato quanto à autoria dos trechos comentados, como forma de solução das dificuldades mais frequentes ou aprofundamento dos acertos. Cada Pauta de Revisão tem conteúdo único, pois sua elaboração é um reflexo do que efetivamente foi produzido pelos alunos, apontando, portanto, quais aspectos devem ser revistos com o propósito de consolidar o conhecimento necessário para passar às próximas etapas da produção do Resumo.

Com relação a esse encadeamento de atividades, acrescentamos que a presente proposta de ensino de artigo científico prevê reformulações conforme as observações feitas após as tarefas pedidas e a consequente organização das Pautas de Revisão. Podem ser programadas atividades complementares sob diferentes perspectivas teóricas, desde que consideradas adequadas à solução de dificuldades detectadas durante o processo de produção textual. As observações sobre as recorrências feitas na Pauta de Revisão contribuem para identificar o que precisa ser retomado ou aprofundado

O próximo conjunto de atividades da Sequência da Figura 6 é referente à TAREFA 2: PRODUÇÃO de um Resumo para artigo científico (cf. 8, 9, 10 e 11), e dele constam: uma proposta de Tarefa a ser postada online (cf. 8); a Devolutiva de Comentários Individuais (cf. 9), também enviada online; a elaboração, por parte do professor, e a discussão presencial da Pauta de Revisão (cf. 10) e a posterior Reescrita Final da produção do Resumo (cf. 11), realizada pelos alunos, após o aprofundamento e a solução de questões recorrentes que suscitaram dificuldade, e postada no ambiente virtual de aprendizagem, encerrando essa Sequência.

Referindo-se a essas atividades, encontram-se reproduzidos a seguir, e também na seção de ANEXOS desta pesquisa, dois documentos: I) uma tarefa enviada por aluno, sob o título de "Tarefa de Aluno: Resumo", com os comentários do professor (ANEXO B); e II) um exemplo de Pauta de Revisão, sob o título de "Pauta de revisão: RESUMO", elaborada a partir da observação do conjunto de tarefas e discutida presencialmente com os alunos (ANEXO C). 


\section{I) Tarefa de Aluno: Resumo}

Referente à Sequência Didática da Produção do Resumo, a reprodução a seguir contém o texto produzido pelo aluno e os comentários feitos pelo professor, numerados de acordo com a numeração dos segmentos de texto a que se referem. O uso apenas das iniciais do nome do aluno garantiu o sigilo quanto à autoria dessa tarefa, embora o autor tenha autorizado sua reprodução.

\section{ARGUMENTATIVIDADE E COESÃO NOS TEXTOS JORNALÍSTICOS: INSTRUMENTOS DE INFLUÊNCIA NA FORMAÇÃO DA OPINIÃO PÚBLICA (1)}

R. S. R. (2)

Resumo (3): Este artigo tem como objetivo demonstrar (4) como a argumentatividade e a coesão são fatores determinantes, em artigos jornalísticos, para a formação da opinião pública. Por meio da análise do artigo jornalístico "Possível ataque à Síria não tem base jurídica", escrito para um site de consultoria jurídica, buscar-se (5) explicitar o uso da argumentação e da coesão como instrumentos essenciais para se atingir um público determinado e para possibilitar que o texto exerça influência na formação da opinião deste público (6) Para tanto, toma-se como base... NÃO CONSIGO ENCONTRAR TEORIAS/AUTORES PARA ME BASEAR.PODERIA, POR FAVOR, ME AJUDAR? (7) (8)

Palavras-chave: Argumentatividade e coesão. artigo jornalístico. formação da opinião pública. (9)

\section{Comentários do Professor:}

(1) O título merece ser melhorado. Sugestão: Discurso jornalístico: um estudo dos mecanismos de textualidade na formação de opinião.

(2) Complete com o nome da instituição à qual você pertence: R.S.R. - FFLCH-USP.

(3) Seu resumo não atinge o número mínimo de palavras, procure ampliar.

(4) Prefira 'observar'.

(5) Digitação: 'busca-se'.

(6) Evite repetição. Delete e insira 'dos leitores'.

(7) Sugestões de bibliografia - adicionei a primeira à lista que já havia mandado por mensagem: 
CHARAUDEAU, P. Discurso das mídias. São Paulo: Contexto, 2007.

KOCH, I. G. V. Argumentação e Linguagem. São Paulo: Cortez, 2004.

PERELMAN, C., OLBRECHTS-TYTECA, L. Tratado da Argumentação: a Nova Retórica. $2^{a}$ ed. Trad. Maria Ermantina Galvão. São Paulo: Martins Fontes, 2005. (Original: PERELMAN, C. \& OLBRECHTS-TYTECA, L. Traité de l'Argumentation. La nouvelle rhetórique. Bruxelles: Éditions de l' Université de Bruxelles, (1958). 1983.)

PLANTIN, C. A Argumentação: História, teorias, perspectivas. Trad. Marcos Marcionilo. São Paulo: Parábola, 2008. (Original: PLANTIN, C. L'Argumentation. Paris: Presses Universitaires de France, 2005)

(8) Como forma de ampliar, você poderia antecipar alguns resultados de sua análise.

(9) Palavras-chave iniciadas por maiúscula. Prefira separar: Argumentatividade. Coesão.

\section{II) Pauta de revisão: RESUMO}

Reprodução da Pauta de Revisão sobre a Produção de Resumo, elaborada a partir de recorrências nos comentários individuais feitos sobre a atividade Tarefa 2: Produção de um Resumo para artigo científico.

Pauta de revisão: RESUMO

TAREFA 2: PRODUÇÃO de um Resumo para artigo científico: Escrever um Resumo Acadêmico, sobre tema de sua escolha, com 250 a 300 palavras e 3 a 5 palavras-chave. Enviar via ambiente virtual.

Observações após comentários individuais nas tarefas apresentadas:

a) Quanto à superestrutura:

O RESUMO deveria conter:

- Justificativa / Objetivo

- Perspectiva teórica

- Metodologia

- Resultados

- Conclusão

Obs.: Nos comentários recebidos individualmente, sua produção foi comentada quanto à Superestrutura Esquemática do Resumo (Justificativa / Objetivo; Perspectiva teórica; Metodologia; Resultados; Conclusão). Para atingir a adequação, sua produção deveria conter todos esses elementos.

b) Quanto ao tema: 
- Manter o FOCO - o 'mundo' não cabe em um artigo.

c) Quanto às Fontes de pesquisa:

- Preferir consultar livros e artigos publicados para a fundamentação teórica. Procurar sites oficiais para colher dados e informações.

d) Quanto aos elementos linguísticos:

- Verificar uso de Este/esse - referência a termo posterior ou mais próximo/referência a termo anterior ou mais distante

- Optar por linguagem mais formal: “... o fato de a análise levar ao conhecimento ..."

- Verificar concordância na Passiva sintética: “...gerando uma tendência de se realizarem pesquisas..."

- Preferir “... executaram-se os protocolos de investigação..." pois é equivalente a 'foram executados os protocolos de investigação"

- Verificar uso de vírgula: “... um teste será aplicado e, após uma semana, outros examinadores..."

- Preferir o uso formal ao popular. Sugestão: "projetos mais bem dimensionados" em vez de "projetos melhor dimensionados". Indica-se como norma culta da língua: Para intensificar sentido de verbos = ele dimensionou melhor / ele conhece melhor. Para acompanhar expressões adjetivas com verbos no particípio, o 'mais' se refere a 'bem dimensionado' / 'o mais bem preparado'.

- Uso dos verbos conforme o objetivo do Resumo. Se for para um Projeto, tempos no futuro. Para um Artigo, preferir tempos no presente ou no passado. Procurar uniformizar o uso dos tempos verbais.

- Utilizar para dúvidas sobre o Novo Acordo Ortográfico o link para a página de busca no VOLP da Academia Brasileira de Letras: http://www.academia.org.br/nossa-lingua/busca-no-vocabulario?sid=23

Reprodução de alguns Comentários recorrentes:

- Observe sempre as normas definidas pelo periódico ou instituição em que seu texto será publicado. Essas normas sempre prevalecerão. 
- Seu resumo está bastante adequado, pois as principais características estruturais estão presentes, como você pode observar nas marcações coloridas em seu texto reproduzido. Os recursos linguísticos utilizados estão adequados, salvo observações feitas.

- Contamos as palavras do Resumo exclusivamente pelas palavras que estão no corpo do texto. Seu resumo está um pouco acima/abaixo do limite da tarefa, mas o importante é consultar as normas da instituição de publicação.

- Em geral, a palavra Resumo antecede o texto. Em geral adota-se o alinhamento Justificado.

- Fiquei curiosa pelo título. Se possível, coloque-o ao reescrever.

- Confira as normas de publicação. Em geral, entre o título e o início do Resumo, colocam-se o nome do autor e da instituição à qual está vinculado.

Passamos, no próximo item, a comentar o conjunto de atividades referentes à abordagem da Produção da Introdução do Artigo científico.

\subsubsection{Sequência Didática da Produção da Introdução}

Para comentarmos a Figura 8, a seguir, correspondente à "Sequência Didática da Produção da Introdução", vamos nos reportar à numeração de 1 a 11 que se encontra dentro das formas em amarelo e que indicam a ordem das atividades realizadas. 
SEQUÊNCIA DIDẢTICA: INTRODUÇÃO

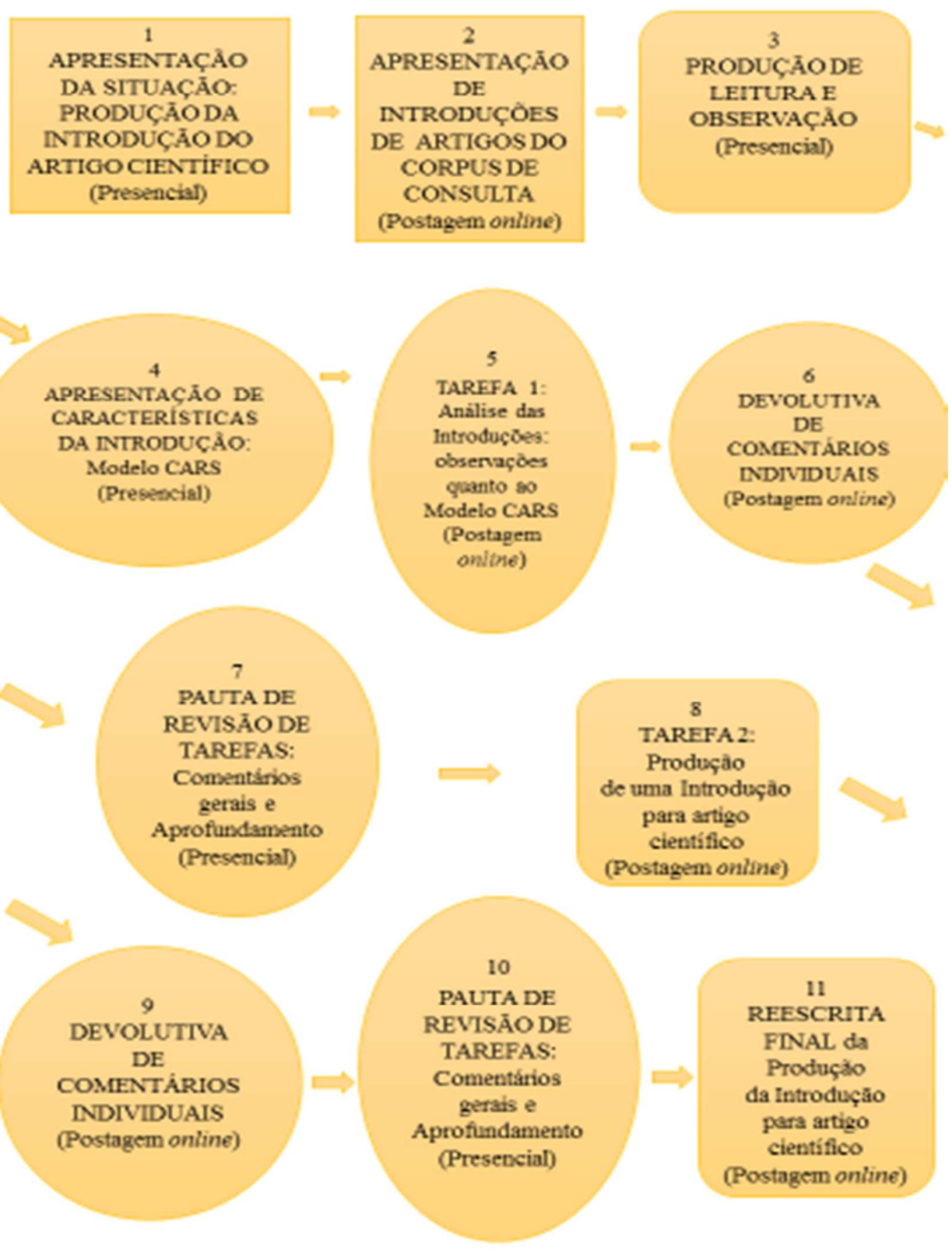

Figura 8 - Sequência Didática da Produção da Introdução 
Nessa Sequência Didática, a Apresentação da Situação (cf. 1) de produzir a Introdução do artigo científico é iniciada em ambiente presencial, com a formação de grupos para realizar a leitura desta seção presente em artigos do corpus de consulta, seguida da atividade de sintetizar e apresentar por escrito as principais ideias contidas no texto lido. Segundo Haythornthwaite e Andrews (2011, p. 13), a interação presencial em grupos pequenos permite a troca de inúmeras informações que podem facilitar a construção colaborativa de conhecimento.

A próxima atividade em ambiente presencial será a Produção de leitura e observação (cf. 3), antecipadamente preparada com a postagem de Introduções de artigos cujos links se encontram no Corpus de consulta (cf. 2) no ambiente virtual de aprendizagem. Ainda conforme Haythornthwaite e Andrews (2011, p. 14), a assincronia e a mobilidade dos ambientes virtuais de aprendizagem conectam amplamente os sujeitos envolvidos e promovem rápida atualização e integração de informação, portanto o desenvolvimento dessa preparação de atividade mostra-se mais adequado ao ambiente virtual.

Como a atividade de Leitura e Observação (cf. 3) prevê uma ação comparativa para a observação de características da Introdução, foram escolhidos, para a turma de Estatística, os artigos "Predição de séries financeiras utilizando wavelets e redes neurais: um modelo para os fundos de investimentos imobiliários" e "Teoria semiótica e ensino de redação"; para os alunos de Letras, os artigos "Interação e conflito no discurso oral culto" e "Teoria semiótica e ensino de redação"49. A partir dessa leitura comparativa das Introduções dos artigos sugeridos para cada área, os estudantes recebem a tarefa observar e comentar diferenças e semelhanças entre os textos lidos. ${ }^{50}$

${ }^{49}$ São referências dos artigos mencionados:

AQUINO, Z. G. O. Interação e conflito no discurso oral culto (SBPC 98). Linha D'Água, n. spe, p. 1123, 2000. Disponível em http://www.revistas.usp.br/linhadagua/article/view/69174/71626> Acesso em 25/04/2016.

SOARES, F.; FROZZA, R.; PAZOS, R. E. Predição de séries financeiras utilizando wavelets e redes neurais: um modelo para os fundos de investimentos imobiliários. Cadernos do IME-Série Estatística, vol. 25, n. 2, pp. 36-53, 2008. Disponível em <http://www.epublicacoes.uerj.br/index.php/cadest/article/view/15732/11903> Acesso em 26/04/2016

GOMES, R. S. Teoria semiótica e ensino de redação. Cadernos do CNLF (CiFEFil), v. X, pp. 202216 , 2007. Disponível em: <https://docs.google.com/viewer?a=v\&pid=sites\&srcid=ZGVmYXVsdGRvbWFpbnxwcm9mYWRy YXJ1Z2luYXNvdXphZ29tZXN8Z3g6NWU1MGFhZjA2Y2ZmY2UxYg> Acesso em 25/04/2016.

${ }^{50}$ Deu-se preferência, para a apresentação das atividades que esta pesquisa propõe, por utilizar artigos e outros gêneros de textos acadêmicos que estejam publicados em edições online de revistas científicas, com livre acesso a quem deseje lê-los ou estudá-los. 
No encontro presencial seguinte, ocorre a Apresentação de características da Introdução (cf. 4), por meio de leitura e discussão em grupos, para preparar para a tarefa que será proposta. Foi utilizado, como indica Swales (1990, p. 141), o Modelo CARS (Creating A Research Space) da Introdução de artigos, conforme a figura ${ }^{51}$ a seguir, recuperada do Capítulo 3 deste estudo.

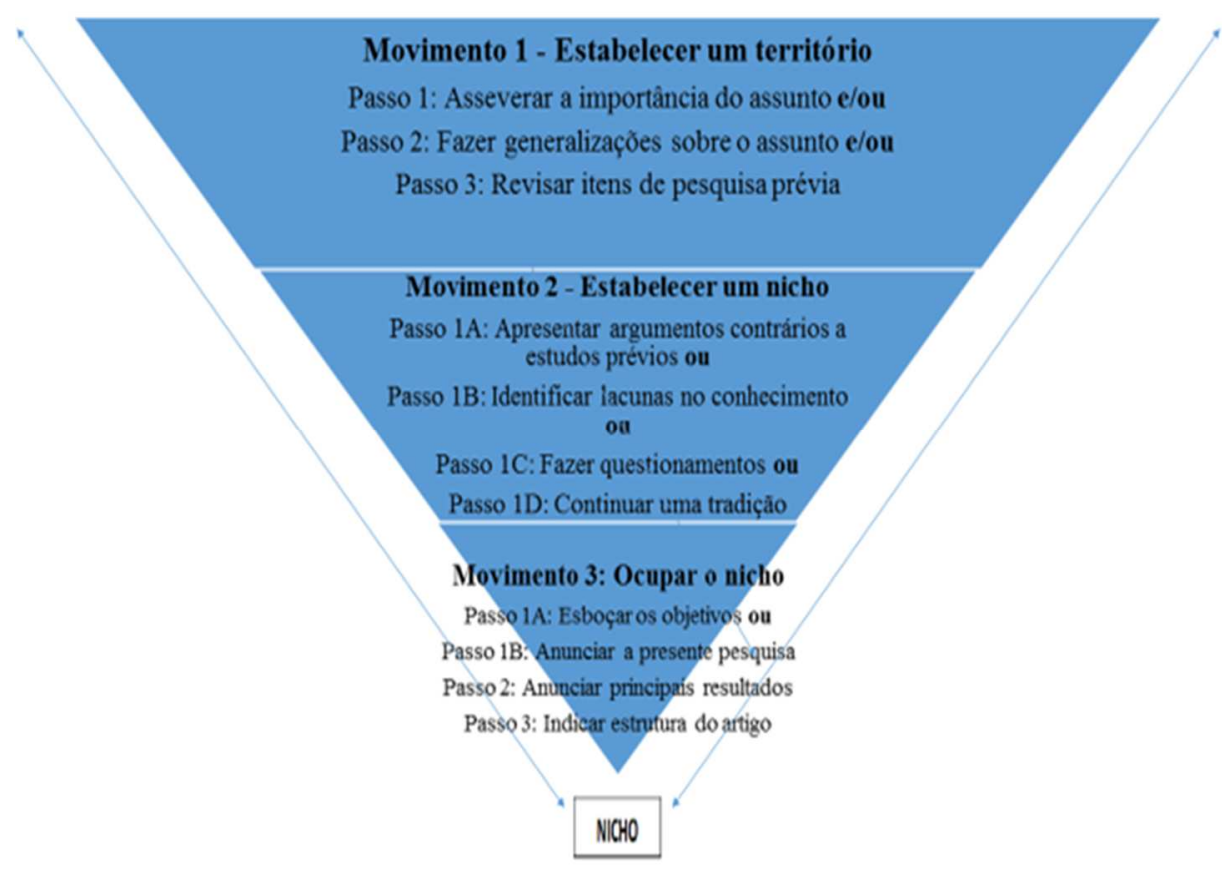

Figura 4 - Modelo CARS da Introdução de Artigos (SWALES, 1990, p. 141, In: Motta-Roth e Hendges, 2010, p. 83)

A atividade seguinte constitui uma tarefa, com o objetivo de Análise das Introduções, quanto ao Modelo CARS (cf. 5), em que os alunos, individualmente, produzem um pequeno relatório sobre os pontos de contato entre a observação feita nos textos concretos e os esquemas teóricos apresentados, ou seja, o Movimento 1, de Estabelecer um território; o Movimento 2, de Estabelecer um nicho; e o Movimento 3, de Ocupar um nicho. A entrega desta tarefa é por postagem online, bem como a Devolutiva de comentários individuais (cf. 6) por parte do professor, que faz anotações breves e particulares em cada postagem. Depois de cada tarefa ser realizada e comentada individualmente pelo professor, é elaborada uma Pauta

${ }^{51}$ A Figura "Modelo CARS da Introdução de Artigos (SWALES, 1990, p. 141, In: Motta-Roth e Hendges, 2010, p. 83)" já foi referida no Capítulo 3 com a numeração "Figura 4", portanto optamos por retomá-la com a mesma numeração, visto tratar-se da mesma figura. 
de Revisão de Tarefas (cf. 7), com comentários gerais sobre todas as tarefas realizadas individualmente.

Após os comentários individuais sobre a segunda tarefa pedida aos alunos, Produção de uma Introdução para artigo científico (cf. 8), foi organizada uma Pauta de Revisão (cf. 10) tendo em vista a produção de Objetivos como parte da Introdução do artigo, uma questão que provocou dúvidas quanto à utilização de elementos linguísticos adequados. Em ambiente presencial, utilizou-se o material a seguir, em forma de PowerPoint, para apresentar a questão sob outro ponto de vista, observando a relação entre ação e finalidade detectadas a partir do uso real das expressões linguísticas na produção de Objetivos.

\section{Pauta de Revisão: O objetivo na Introdução do Artigo Científico}

1. Exame de comentários sobre produção de Objetivos

2. Sugestão de Elementos Linguísticos a utilizar

3. Reescrita do Objetivo

\section{Segmento de texto enviado como tarefa}

Em nossa pesquisa, utilizaremos o programa $R$ para simular o comportamento de um grid, representação computacional de um material poroso, analisando as mudanças em seu comportamento quando as variáveis: número de simulações, probabilidade de infiltração, tamanho e tipo de grid são alteradas. 


\title{
COMENTÁRIOS do professor
}

'Utilizar' não é verbo indicado para produção de objetivo. Ele se ajusta mais à metodologia. A sugestão é que você o substitua pelo verbo 'observar' e o PARA seja deslocado iniciando a finalidade, que é 'descrever as mudanças'. Experimente fazer essas substituições e os ajustes necessários para que seu objetivo fique mais claro

\section{Uma possibilidade de Reescritura, após os comentários do Professor}

\begin{abstract}
Em nossa pesquisa, observaremos a simulação promovida pelo programa $\mathrm{R}$ quanto ao comportamento de um grid, representação computacional de um material poroso, para descrever as mudanças que ocorrem quando são alteradas as variáveis: número de simulações, probabilidade de infiltração, tamanho e tipo de grid.
\end{abstract}

Figura 9 - Slides de PowerPoint: Pauta de Revisão

No primeiro slide, é apresentado o tema da Pauta de Revisão e as abordagens a serem contempladas. O segundo slide traz uma produção de aluno e o terceiro, os comentários feitos pelo professor em relação à seleção lexical utilizada. O quarto slide apresenta uma possibilidade de reescrita do segmento em questão, após as indicações do professor.

A última atividade dessa Sequência Didática é a REESCRITA FINAL da Produção da Introdução para artigo científico (cf. 11), realizada após o recebimento, por parte dos alunos, em ambiente privado, dos comentários individuais em sua produção e do exame e a discussão sobre a Pauta de Revisão, atividade que considera a produção dos alunos de forma anônima, para fazer observações gerais sobre estruturas textuais e elementos linguísticos mais adequados, sempre admitindo outras possibilidades. 
Ao propor a atividade da Pauta de Revisão (cf. 10), estamos de acordo com a posição de Castelló e Iñesta (2012, p. 183), de orientar o aluno quando, como e para atender a qual objetivo são usados determinados recursos linguísticos, tomando por base seu próprio texto. Em relação à atividade de Reescritura (cf. 11), também concordamos com tais pesquisadoras ao considerarmos o texto um "artefato em atividade", produzido em sucessivos rascunhos que vão atualizando o texto inicial; e ainda com a perspectiva de Dolz, Noverraz e Schneuwly (2004, p. 95), de que “escrever é (também) reescrever".

Referente à Sequência Didática da Produção da Introdução, encontra-se reproduzido abaixo, e também no ANEXO D deste trabalho, sob o título de: III) "Tarefa de aluno Estatística: Introdução e Reescrita com Resumo", um conjunto de atividades que se referem à tarefa de produção de uma Introdução enviada por aluno da área de Estatística, os comentários feitos pelo professor e a reescrita dessa Introdução a partir dessas observações. No item 4.2 deste capítulo, e também no ANEXO E deste trabalho, há ainda a reprodução de outro conjunto de atividades do mesmo tipo, porém de aluno da área de Letras, sob o título de: IV) “Tarefa de aluno Letras: Introdução e Reescrita”, que será objeto de nossa análise.

\section{III) Tarefa de aluno Estatística: Introdução e Reescrita com Resumo}

Essa reprodução refere-se a um conjunto de atividades: um texto produzido por aluno, os comentários feitos pelo professor numerados de acordo com a numeração dos segmentos de texto a que se referem e a reescrita dessa Introdução a partir das observações. O uso apenas das iniciais do nome do aluno garantiu o sigilo quanto à autoria dessas atividades, embora o autor tenha autorizado sua reprodução.

Instituto de Matemática e Estatística

Universidade de São Paulo

Disciplina: FLC 0474 - "Língua Portuguesa"

Introdução de artigo científico 


\section{Objetivo}

Elaboração de um texto científico sobre o impacto do consumo de álcool sobre a mortalidade no trânsito na cidade de São Paulo para constatar ou não a eficácia da Lei Seca. (1)

\section{Fundamentos}

É conhecida a associação entre o uso do álcool e mortes no trânsito. No texto a $\underline{\text { ser elaborado, }}$ (2) serão utilizados dados recentes sobre o tema, de forma a compor um panorama geral e atual.

A fonte principal de pesquisa serão artigos encontrados no website Google Acadêmico (http://scholar.google.com.br/) os quais mostrem estatísticas recentes a respeito do objetivo proposto. (3)

Este será um trabalho de análise de dados estatísticos obtidos da correlação das mortes no trânsito e consumo de álcool e a base teórica da análise dos dados será de acordo com os fundamentos teóricos que constam na obra de Morettin, P.A. E Bussab, W. O. "Estatística Básica".

Como exemplo de modelo inicial deste, (4) será utilizado o artigo "PERFIL DOS CONSUMIDORES DE BEBIDA ALCÓOLICA DE 18 A 30 ANOS E O IMPACTO DA LEI SECA NO COMPORTAMENTO DOS MORADORES DO RIO DE JANEIRO DE CLASSE A E B", de Castro, G. C. et.al. Publicado no periódico Cadernos do IME - Série estatística, Universidade do Estado do Rio de Janeiro - UERJ, Rio de Janeiro - RJ - Brasil, v.30 p. $19-33,2011$.

Posteriormente serão obtidos dados a respeito da cidade de São Paulo para compor uma base de dados a ser avaliada. $\underline{O}$ período a ser analisado (5) dependerá da qualidade dos dados obtidos, porém como ponto inicial, espera-se fazer um trabalho que avalie cinco anos de mortalidade no trânsito. (6)

São Paulo, 08 de outubro de 2012

C. H. P. S.

\section{Comentários do Professor:}

(1) Ampliar o objetivo: na verdade, o objetivo é descrever o estudo, e o artigo é que tem essa função. Como justificativa da importância de seu estudo, você poderia fazer uma comparação de dados em diferentes épocas para observar se houve aumento ou diminuição de mortalidade, procurando apontar uma razão para isso. É importante definir um local, a cidade de São Paulo, por exemplo - ou algum local de onde você consiga dados com maior facilidade. A hipótese, a ser comprovada ou não, poderia ser de que, mesmo com a Lei Seca, não houve progresso, ou algo assim, que você pode conhecer ao levantar os dados.

(2) Procure não se referir ao próprio texto, mas ao estudo realizado. Fale um pouco mais sobre o contexto em que seu estudo se insere: sobre o consumo de álcool, a Lei Seca, etc. 
(3) Tema de interesse e fonte de dados confiável - mas precisa especificar a base teórica, as teorias/autores que você vai usar no seu artigo - use a técnica da paráfrase ou da citação para colocar as ideias desses autores dentro de seu texto. No seu caso, mencione aquele artigo que já estudamos.

(4) Mencione só o nome do autor e a data (2011) aqui, a Referência completa vai apenas no final do artigo.

(5) Geralmente o estudo já foi feito quando se escreve o artigo para relatá-lo, prefira: "o período analisado foi ..." Pense nisso ao reescrever: há muitos verbos no futuro em sua introdução.

(6) Mencionar COMO - qual é o método / o passo a passo seguido para realizar o estudo. Prefira produzir a introdução sem os subtítulos "Objetivo", "Fundamentos"

Reescrita Final da Introdução: (Já com Título, Resumo e Palavras-chave)

\title{
IMPACTO DA LEI SECA NA MORTALIDADE DE ACIDENTES POR TRÂNSITO EM SÃO PAULO
}

\author{
C. H. P. S.
}

Instituto de Matemática e Estatística da USP

\section{Resumo}

Estudo descritivo com o objetivo de verificar o impacto da lei 11.705/2008, a chamada "Lei Seca" na mortalidade por acidentes de trânsito no município de São Paulo nos anos de 2007 a 2009, (que cobrem os períodos pré e pós Lei Seca) para avaliar a eficácia imediata da lei no sentido de diminuir a mortalidade no trânsito devido ao uso do álcool por parte dos motoristas.

Palavras-chave: lei Seca, município de São Paulo, mortalidade no trânsito.

\section{Introdução}

O consumo de álcool é um hábito difundido na maioria dos países, mesmo levando a consequências como dependência, transtornos mentais, comportamento agressivo, suicídio, neoplasias, absenteísmo, dentre outros (SOIBELMAN et al., 2004, p. 539 - 540). A Organização Mundial de Saúde (OMS, 2002) aponta a combinação de direção e embriaguez como causa específica de morte entre vítimas de Acidentes de Transporte Terrestre, termo esse doravante denominado ATT.

Segundo dados da National Highway Traffic Safety Administration (NHTSA), órgão federal americano responsável pela administração da segurança no trânsito nos Estados Unidos, motoristas com concentração alcoólica de $0,2 \mathrm{~g} / \mathrm{L}$ de sangue já possuem atenção 
dividida com redução nas habilidades visuais e motoras e, quanto maior a concentração de álcool, maior será a probabilidade de ocorrer um ATT (NHTSA, 2008).

No Brasil, tentando diminuir o número de acidentes provocados pela mistura de álcool e direção, foi promulgada, em 19 de junho de 2008, a lei 11.705, conhecida popularmente como "Lei Seca" que alterou o Código de Trânsito Brasileiro. A partir dessa data, o motorista que fosse flagrado numa blitz policial apresentando qualquer concentração de álcool por litro de sangue detectável pelo 'bafômetro' estaria sujeito a multa de $\mathrm{R} \$ 957,00$, apreensão do veículo e suspensão do direito de dirigir por 12 meses. Caso a concentração de álcool no sangue fosse superior a $0,6 \mathrm{~g} / \mathrm{L}$, a infração pode ser classificada como crime com pena de reclusão (D.O.U., 2008).

Levando em conta essa relação entre o consumo de álcool e os ATT, este artigo tem por finalidade avaliar se houve impacto nos números da mortalidade no trânsito da cidade de São Paulo em decorrência da promulgação da Lei Seca.

Vem, a seguir, a próxima Sequência Didática, referente à produção das seções de Apresentação de resultados, Discussão e Conclusão, conforme esquema reproduzido na Figura 10, mais adiante.

4.1.2.3 Sequência Didática da Produção de Apresentação de Resultados, Discussão e Conclusão

Para comentarmos a Figura 10, a seguir, correspondente à "Sequência Didática: Apresentação de Resultados, Discussão e Conclusão", vamos nos reportar à numeração de 1 a 11 que se encontra dentro das formas em verde e que indicam a ordem das atividades realizadas. 


\section{SEQUĖNCLA DIDÁTICA: APRESENTAÇÃO DE RESULTADOS, DISCUSSĀO E CONCLUSÃO}

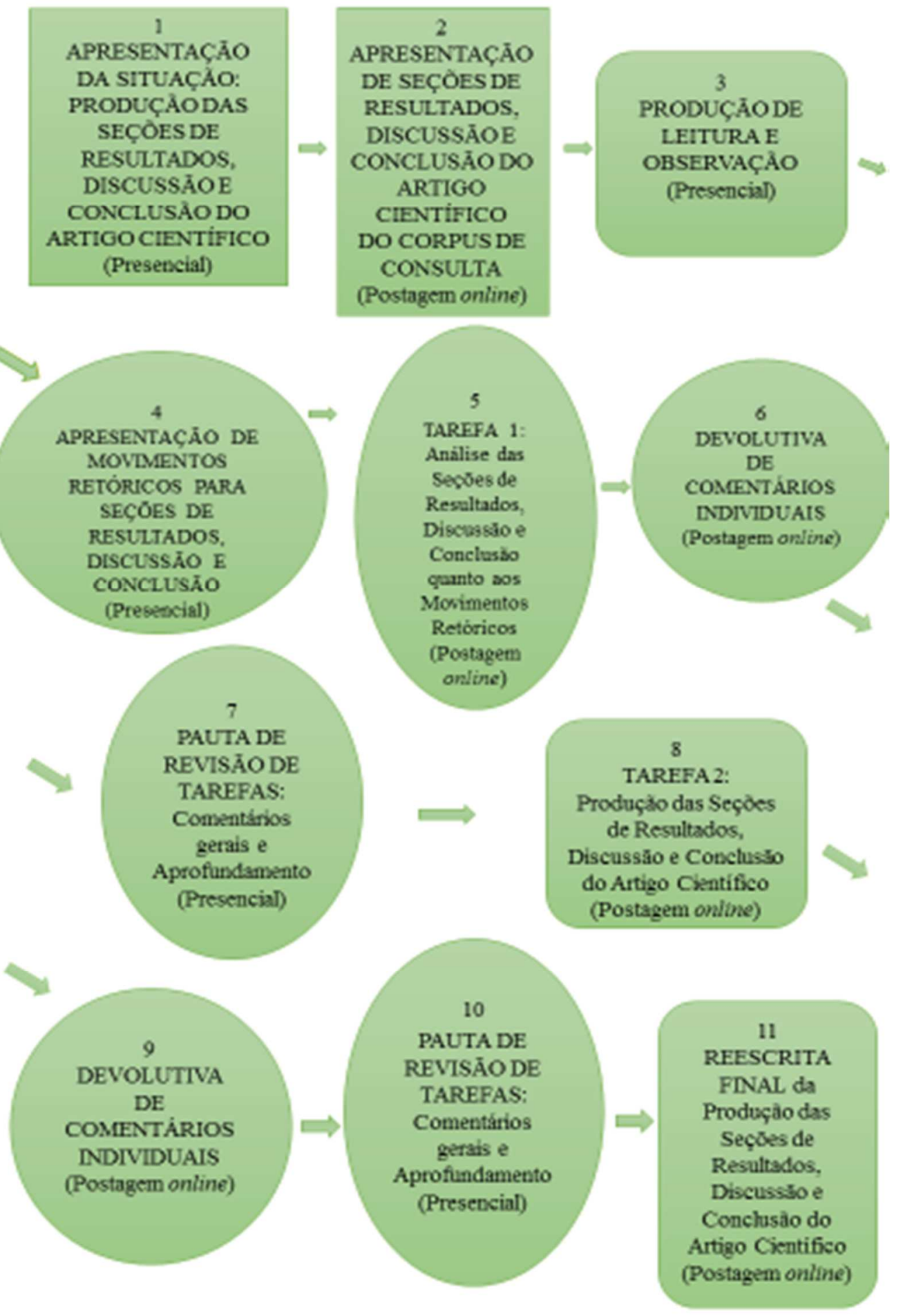

Figura 10 - Sequência Didática: Apresentação de Resultados, Discussão e Conclusão 
As atividades que compõem a Sequência Didática referente à produção das seções de Apresentação de Resultados, Discussão e Conclusão guardam semelhanças com aquelas que apresentam a Introdução, porém diferem em termos de objetivos das seções. Segundo Swales e Feak (2004, p. 222), enquanto a Introdução traz a justificativa e o objetivo do artigo, a seção de Resultados descreve e comenta as descobertas obtidas, e a Discussão generaliza o que se aprendeu no estudo, fazendo referência às declarações da Introdução.

Na APRESENTAÇÃO DA SITUAÇÃO da Produção das seções de Resultados, Discussão e Conclusão (cf. 1), comentam-se esses objetivos presencialmente com os alunos e prepara-se, por meio de postagem online de $\operatorname{artigos}^{52}$ a serem estudados, a atividade de IDENTIFICAÇÃO DE RESULTADOS, DISCUSSÃO e CONCLUSÃO EM ARTIGOS DO CORPUS DE CONSULTA (cf. 2) e propõe-se a atividade presencial de PRODUÇÃO DE LEITURA E OBSERVAÇÃO (cf. 3).

Após esse contato com a linguagem em uso nos textos lidos e a discussão sobre objetivos de cada seção, são apresentados, em aula presencial, os MOVIMENTOS RETÓRICOS PARA RESULTADOS, DISCUSSÃO e CONCLUSÃO (cf. 4), com base numa sintetização feita por Motta-Roth e Hendges (2010, p. 128), levando em conta informações recorrentes em diversos modelos que essas autoras estudaram. Elas identificaram oito movimentos retóricos, apresentados aos alunos por meio da figura que segue:

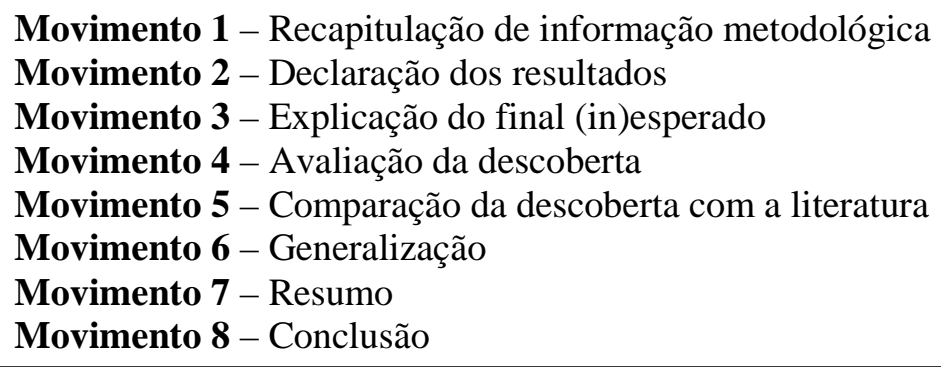

Figura 11 - Síntese da organização retórica da seção de resultados e discussão (retirada de Motta-Roth e Hendges, 2010, p. 128)

\footnotetext{
${ }^{52}$ Foram escolhidos e adicionados ao Corpus de Consulta, respectivamente para as turmas de Letras e Estatística, os artigos cujas referências são:
}

BASNIAK, M. I.; CHAVES NETO, A. Avaliação de recursos tecnológicos implantados no ensino básico através da análise de correlação canônica. Cadernos do IME-Série Estatística vol. 29, n. 2, pp. 47-62, 2010. Disponível em: http://www.e-publicacoes.uerj.br/index.php/cadest/article/view/15736/1190747 Acesso em 27/04/2016. Acesso em 27/04/2016.

AQUINO, Z. G. O.; Luques, S. U. Propaganda político-eleitoral - um discurso em busca de legitimidade. Linha $\begin{array}{lllllll}\text { D'Água, vol. } & 25, & \text { n. } & 2, & \text { pp. } & 131-145 . & \text { Disponível }\end{array}$ http://www.revistas.usp.br/linhadagua/article/view/47718/51453 Acesso em 27/04/2016. 
As autoras indicam que alguns desses movimentos são essenciais, como a Declaração de resultados (Movimento 2), a Explicação do final (in)esperado (Movimento 3), a Comparação da descoberta com a literatura (Movimento 5) e a Conclusão (Movimento 8), mas que os demais movimentos retóricos também são usados, mais ou menos frequentemente, conforme as características da pesquisa realizada. Motta-Roth e Hendges (2010, p. 128) relacionam a relevância desses movimentos à função primordial do gênero artigo acadêmico de "relatar resultados de uma pesquisa, avaliando-os em relação à literatura na área e fornecendo uma conclusão quanto a seu significado. " (MOTTA-ROTH e HENDGES, 2010, p. 128)

Referindo-se ao movimento retórico da Conclusão, essas pesquisadoras observam que essa seção pode vir como uma parte da discussão dos resultados, ou como uma seção independente, sinalizada por títulos como "Conclusão" ou "Considerações finais". MottaRoth e Hendges (2010, p. 140) também indicam elementos linguísticos que podem compor as seções finais do artigo acadêmico, exemplificando com uma série de expressões e verbos mais utilizados. Oferecer ao aluno essa informação sobre a organização das seções tanto em termos de sua funcionalidade como das microestruturas expressas no discurso, tem o propósito de prepará-lo para as duas tarefas seguintes: Análise das Seções quanto aos Movimentos Retóricos (cf. 5) e Produção das seções de Resultados, Discussão e Conclusão (cf. 8).

Para a Tarefa de Análise das Seções quanto aos Movimentos Retóricos (cf. 5), os alunos devem examinar os artigos “Avaliação de recursos tecnológicos implantados no ensino básico através da análise de correlação canônica" e "Propaganda político-eleitoral - um discurso em busca de legitimidade" já referenciados anteriormente, com o intuito específico de identificar os elementos linguísticos que introduzem os movimentos retóricos de Declarar resultados, Comparar a descoberta com a literatura e Concluir.

Em geral, todas as tarefas são postadas no ambiente virtual de aprendizagem, e todos os alunos recebem uma Devolutiva de comentários individuais (cf. 6 e 9) também por esse meio. Em seguida, organiza-se uma PAUTA DE REVISÃO (cf. 7 e 10) que é apresentada presencialmente ao grupo de alunos, com os comentários mais gerais e a abordagem das questões que merecem aprofundamento. O procedimento é o mesmo para a Tarefa de Produção das seções de Resultados, Discussão e Conclusão (cf. 8). A postagem online da REESCRITA FINAL da Produção das seções de Resultados, Discussão e Conclusão (cf. 11) é a última atividade, finalizando o processo. 
Gostaríamos de acrescentar que a avaliação realizada nas duas aplicações desta proposta, tema sobre o qual não nos aprofundamos neste trabalho por não ser este seu foco, incluiu uma consulta informal aos alunos sobre suas impressões referentes às atividades realizadas em ambientes presenciais e virtuais e observou a frequência e a participação nessas atividades, dada a importância do envolvimento dos participantes durante todo o processo de construção de conhecimento. Além disso, foi considerada a adequação da produção individual, por parte dos alunos, de um artigo científico, conforme as indicações teóricas feitas durante o curso.

Feitas as explicitações referentes às aplicações das Sequências Didáticas, voltamos nossa atenção para as implicações cognitivas dessas atividades, que constituem um dos objetivos centrais desta pesquisa, pois que importa conhecer o processo de produção textual dos alunos para observar como ocorreu a dinâmica de construção de conhecimento por parte deles. Para tanto, reproduzimos e procedemos à análise, no item a seguir, de Tarefa referente à Produção e Reescrita de Introdução.

\subsection{Reprodução e Análise da Tarefa de aluno Letras: Introdução e Reescrita}

Reproduzimos a seguir o conjunto de atividades referentes à Produção de Introdução para o artigo científico, sob o título: IV) "Tarefa de aluno Letras: Introdução e Reescrita”, também constante do ANEXO E deste trabalho, a saber: a) Primeira versão da Introdução de um artigo científico produzida por aluno ${ }^{53}$; b) Comentários feitos pelo professor numerados (em algarismos romanos) de acordo com a numeração dos segmentos de texto a que se referem; c) Reescrita dessa Introdução a partir das observações, como versão definitiva para compor o artigo que produziu para ser avaliado pela sua participação na disciplina FLC1261 Leitura e Produção de Textos II, do curso de Letras da FFLH-USP.

As linhas referentes à produção da tarefa e à reescrita foram numeradas (em algarismos arábicos) de modo a organizar a subsequente análise quanto às implicações cognitivas de tal atividade.

${ }^{53} \mathrm{O}$ anonimato foi garantido com a reprodução apenas das iniciais como forma de identificação, embora a publicação dessas atividades tenha sido autorizada pelo aluno. 


\section{IV) Tarefa de aluno Letras: Introdução e Reescrita}

a) Primeira versão da Introdução de um artigo científico produzida por aluno:

\section{INTRODUÇÃO}

A opinião pública é amplamente (I) influenciada pelos meios de comunicação. E, com o amplo acesso a informação, possibilitado, principalmente, pela televisão e pela internet, a quantidade de informações que pode hoje ser acessada por uma pessoa é cada vez maior. Em alguns minutos, as notícias percorrem o planeta e milhões de pessoas são influenciadas por elas.

Porém, neste contexto, é preciso refletir sobre como as inúmeras informações colocadas à disposição de cada pessoa diariamente podem, de algum modo, influenciar sua opinião. Nem toda a informação é recebida de modo eficaz (II) e aceita pelo receptor. E, neste processo, a argumentação e a referenciação exercem um papel essencial.

Quando se fala em meios de comunicação especialmente voltados para determinados setores da sociedade, a informação tem que ser trabalhada (III) de modo a facilitar sua aceitação pelo receptor. No meio jurídico, por exemplo, o modo pelo qual a argumentação de um texto é feita e a maneira pela qual os itens que tem (IV) por função estabelecer referências são utilizados tem (V) muita influência para que o receptor aceite aquilo que lhe é transmitido.

Por isso, trabalhar com textos produzidos na mídia para um público específico exige um estudo mais detido do modo de pensar e de conceber o mundo daquele grupo. E é por meio deste conhecimento que a argumentação e a referenciação podem agir de modo bastante incisivo na formação da opinião daquele público.

Este artigo tem como objetivo observar a argumentação e a referenciação como fatores determinantes, em artigos jornalísticos, para a formação da opinião pública, especialmente no que tange a um grupo específico, qual seja o de pessoas ligadas ao mundo jurídico.

É preciso refletir sobre o modo como argumentação e referenciação (VI) são trabalhadas $(V I I)$ em um texto para que ele atinja seu objetivo. Será que basta apenas argumentar para influenciar a opinião deste público? Ou é preciso trabalhar com a 
argumentação e com o modo de utilização dos itens referenciais e direcioná-los ao modo de pensar e de conceber o mundo daquele público em especial?

A argumentação está intimamente ligada, na concepção contemporânea, às noções de verdade e de verossimilhança. (VIII) A noção do crível, do razoável, baseia seu estudo. A argumentação é, em suma, um modo de alcançar ou intensificar o assentimento do público, utilizando-se do discurso.

O ser humano tem o poder de impregnar na linguagem marcas de subjetividade relativas às suas crenças em geral. A maneira pela qual cada indivíduo percebe a realidade é revelada pelo uso das expressões referenciais, que se tornam ainda mais relevantes em textos formais escritos que tem (IX) por objetivo convencer alguém a compartilhar dado ponto de vista.

Por meio da análise das estratégias argumentativas utilizadas e de como ocorre a referenciação no artigo jornalístico "Possível ataque à Síria não tem base jurídica", publicado em um site de consultoria jurídica em 02/09/2013, busca-se explicitar, no presente artigo, o uso da argumentação e da referenciação como instrumentos essenciais para se atingir um público determinado e para possibilitar que o texto exerça influência na formação da opinião deste público.

Para tanto, toma-se como base as pesquisas de Koch (1996), Maingueneau (2000) e Marcuschi (1998).

OBS.: desenvolverei mais a questão da base teórica utilizada após iniciar o desenvolvimento do artigo. Como ainda não defini os autores nos quais me basearei, não consigo desenvolver muito este ponto na introdução. R. S. R. (X)

b) Comentários feitos pelo professor numerados (em algarismos romanos) de acordo com a numeração dos segmentos de texto a que se referem:

\section{Comentários do Professor:}

(I) Seleção lexical / repetição - sugiro rever 
(II) Pense um pouco nisso - o que significaria 'receber informação de modo eficaz'? - o interlocutor vai interpretar segundo seu repertório/seu mundo - ele pode até ser influenciado, convencido - por isso o uso das estratégias argumentativas e de referenciação

(III) Prefira construída/elaborada

(IV) têm

(V) têm

(VI) Substituir para evitar repetição

(VII) Rever repetição

(VIII) Procure citar o autor/ao autores que expressam esse pensamento

(IX) têm

(X) Ok. Aguardo a reescrita final.

c) Reescrita dessa Introdução a partir das observações, como versão definitiva para compor o artigo que produziu para ser avaliado pela sua participação na disciplina FLC1261 Leitura e Produção de Textos II, do curso de Letras da FFLH-USP:

\section{INTRODUÇÃO}

A opinião pública é fortemente influenciada pelos meios de comunicação. E, com o amplo acesso à informação, possibilitado, principalmente, pela televisão e pela internet, a quantidade de informações que pode hoje ser acessada por uma pessoa é cada vez maior. Em alguns minutos, as notícias percorrem o planeta e milhões de pessoas são influenciadas por elas.

Neste contexto, é preciso refletir sobre a organização do discurso e como as inúmeras informações colocadas à disposição de cada pessoa diariamente podem, de algum modo, influenciar sua opinião. Sabemos que nem toda a informação é recebida do modo como o autor pretendeu inicialmente e aceita pelo receptor como aquele espera. É, neste processo, que a argumentação e a referenciação exercem um papel essencial.

Quando se fala em meios de comunicação especialmente voltados para determinados setores da sociedade, a informação tem que ser formulada de modo a facilitar sua aceitação pelo receptor. No meio jurídico, por exemplo, o modo pelo qual a argumentação de um texto é

60 feita e a maneira pela qual os itens que têm por função estabelecer referências são utilizados influenciam a aceitação pelo receptor daquilo que lhe é transmitido. 
Por isso, trabalhar com textos produzidos na mídia para um público específico exige um estudo mais detido do modo de pensar e de conceber o mundo daquele grupo. E é por meio deste conhecimento que a argumentação e a referenciação podem agir de modo bastante incisivo na formação da opinião daquele público.

Este artigo tem como objetivo observar a argumentação e a referenciação como fatores determinantes, em artigos jornalísticos, para a formação da opinião pública, especialmente no que tange a um grupo específico, qual seja o de pessoas ligadas ao mundo jurídico.

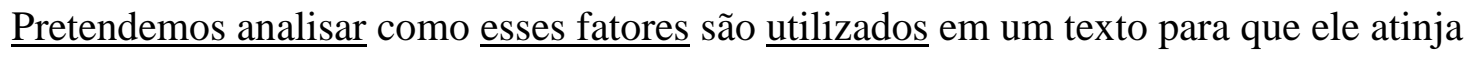
seu objetivo. Será que basta apenas argumentar para influenciar a opinião deste público? Ou é preciso trabalhar com a argumentação e com o modo de utilização dos itens referenciais e direcioná-los ao modo de pensar e de conceber o mundo daquele público em especial?

Para responder a essas questões, partimos dos seguintes conceitos (PALUMBO, 2007): 1. A argumentação está intimamente ligada, na concepção contemporânea, às noções de verdade e de verossimilhança. A noção do crível, do razoável, baseia seu estudo; 2. A argumentação é, em suma, um modo de alcançar ou intensificar o assentimento do público, utilizando-se do discurso.

O ser humano tem o poder de impregnar na linguagem marcas de subjetividade relativas às suas crenças em geral. A maneira pela qual cada indivíduo percebe a realidade é revelada pelo uso das expressões referenciais, que se tornam ainda mais relevantes em textos formais escritos que têm por objetivo convencer alguém a compartilhar dado ponto de vista (SILVA, 2011).

Por meio da análise das estratégias argumentativas utilizadas e de como ocorre a referenciação no artigo jornalístico "Possível ataque à Síria não tem base jurídica", publicado em um site de consultoria jurídica em 02/09/2013, busca-se explicitar, no presente artigo, o uso da argumentação e da referenciação como instrumentos essenciais para se atingir um público determinado e para possibilitar que o texto exerça influência na formação da opinião deste público.

Para tanto, toma-se como base as pesquisas de Marcuschi (2002), Palumbo (2007) e 90 Charaudeau (2006). Em Marcuschi temos teoria dos gêneros como fruto da história e da sociedade e o estudo sobre a possibilidade de os gêneros aparecem mesclados nos textos, afastando a concepção de que estes são estáticos e imutáveis. Palumbo, por sua vez, desenvolveu uma pesquisa sobre referenciação e argumentação nas orientações 
argumentativas. Por fim, Charaudeau trata do discurso nas mídias e de como ocorre a recepção das informações veiculadas pelos receptores.

Nossa análise das implicações cognitivas desta tarefa de aluno tem o propósito de observar como ocorreu a dinâmica de construção de conhecimento nesta prática que envolve produção textual em Língua Portuguesa, tomada, segundo Marcuschi (2008), como atividade interativa, social e mental estruturadora de nosso conhecimento. Em conformidade com os posicionamentos expressos em Fauconnier e Turner (2002) e Fauconnier (2005), mencionados no Capítulo 2 deste trabalho, buscamos examinar, de maneira integrada ao processamento discursivo e interacional, implicações cognitivas dessa atividade de produção de texto por meio da seleção lexical. ${ }^{54}$

É possível observar, na transcrição dos exemplos (1) e (2) a seguir, o primeiro retirado da versão inicial e o segundo da reescrita, que o aluno R.S.R. acolheu a sugestão apontada no Comentário (I) e optou por uma seleção lexical mais ajustada, que valorizou sua produção em termos de adequação e variação vocabular:

(1) A opinião pública é amplamente (I) influenciada pelos meios de comunicação. E, com o amplo acesso a informação, ... ( linhas 3 e 4)

(2) A opinião pública é fortemente influenciada pelos meios de comunicação. E, com o amplo acesso à informação, ... (linhas 47 e 48)

Quanto ao Comentário II ('o que significa receber informação de modo eficaz?'), é possível dizer que a indagação feita pelo professor levou o aluno a refletir sobre o conceito de 'eficácia', reformulando sua produção, de maneira mais adequada ao que ocorre no processamento discursivo, como se pode verificar nos exemplos (3) e (4) a seguir, retirados da versão inicial e da reescrita respectivamente:

Nem toda a informação é recebida de modo eficaz (II) e aceita pelo receptor. (linha 10)

(4) Sabemos que nem toda a informação é recebida do modo como o autor pretendeu inicialmente e aceita pelo receptor como aquele espera. (linhas 54 e 55)

54 Retomando posicionamento que consta do Capítulo 2, para Fauconnier, conhecimentos linguísticos e gramaticais fornecem evidências para atividades mentais implícitas, como a construção, a conexão e a transferência de espaços mentais - conjuntos de memória de trabalho que construímos enquanto pensamos e falamos - numa integração a partir da qual podem surgir novas estruturas criativas à medida que se avança no processo cognitivo, configurando a construção do conhecimento. (COSCARELLI, 2005, p. 291) 
Interessa ainda, para nossos estudos, observar a situação desencadeada pelo Comentário III - 'Prefira construída/elaborada', feito em relação ao termo 'trabalhada' (exemplo 5), que se repete em sua forma plural 'trabalhadas' (exemplo 6), objeto do Comentário VII.

Embora na reescrita o aluno não tenha acolhido especificamente as sugestões feitas pelo professor, o texto final apresenta uma seleção lexical mais adequada às questões linguístico-discursivas de produção de enunciados na primeira (exemplo 7) e na segunda ocorrências (exemplo 8), inclusive evitando a repetição. Essas reformulações indicam que houve, por parte do aluno, atividades mentais implícitas envolvendo aspectos teóricos e linguísticos, indicadoras tanto da construção de conhecimento, como do desenvolvimento de um certo grau de independência, já que o aluno preferiu buscar uma solução alternativa à sugestão do professor.

Na versão inicial, temos:

(5) Quando se fala em meios de comunicação especialmente voltados para determinados setores da sociedade, a informação tem que ser trabalhada (III) de modo a facilitar sua aceitação pelo receptor. (linhas 12 a 14)

(6) É preciso refletir sobre o modo como argumentação e referenciação (VI) são trabalhadas (VII) em um texto para que ele atinja seu objetivo. (linhas 25 e 26)

Na reescrita:

(7) Quando se fala em meios de comunicação especialmente voltados para determinados setores da sociedade, a informação tem que ser formulada de modo a facilitar sua aceitação pelo receptor. (linhas 57 a 59)

(8) Pretendemos analisar como esses fatores são utilizados em um texto para que ele atinja seu objetivo. (linhas 69 e 70)

Ainda em relação aos exemplos (6) e (8), em que o professor aponta, no Comentário VI, a necessidade de 'Substituir para evitar repetição', o aluno, aplicando a própria teoria da Referenciação, substitui na reescrita 'argumentação e referenciação' pelo termo 'fatores', retomado do parágrafo anterior (linha 22 na versão inicial, linha 66 na reescrita).

Pode-se observar também que a transcrição do exemplo (8) marca uma mudança de atitude em relação à própria pesquisa, ao substituir 'É preciso refletir' do exemplo (6) por 'Pretendemos analisar', em combinação com a troca de 'trabalhadas', do exemplo (6), para 'utilizados' (exemplo 8). Poderíamos dizer que a seleção lexical da reescrita é indício de estrutura emergente que sugere um envolvimento maior do aluno com questões como o 
funcionamento dinâmico da linguagem e a postura do pesquisador em investigar seu uso, posicionamentos defendidos durante o curso sobre produção de artigo científico.

O Comentário VIII, feito em relação ao exemplo (9) da versão inicial, a seguir, referese à questão da incorporação de outras vozes no discurso do aluno devido à função epistêmica da escrita acadêmica, de envolver a construção e a transformação de conhecimento, levando em conta as bases teóricas já estabelecidas pelo campo de pesquisa escolhido. (CASTELLÓ e INESTA, 2012, p. 180)

A reescrita do segmento, transcrita no exemplo (10) a seguir, apresenta a inserção do nome do autor consultado e da data da obra, conforme sugestão do professor, reconhecendo a adequação dessa prática.

(9) A argumentação está intimamente ligada, na concepção contemporânea, às noções de verdade e de verossimilhança. (VIII) (linhas 30 e 31 )

(10) Para responder a essas questões, partimos dos seguintes conceitos (PALUMBO, 2007): 1. A argumentação está intimamente ligada, na concepção contemporânea, às noções de verdade e de verossimilhança. (linhas 73 a 75 )

Ainda em relação ao exemplo (10), indicamos o acréscimo, na reescrita, do segmento inicial 'Para responder a essas questões,' que estabelece conexão com o parágrafo anterior, referindo-se a questões de pesquisa mencionadas nas linhas 26 a 29. Consideramos tal segmento uma estrutura criativa emergente, indício de atividade mental implícita que se refere à manutenção do que Swales e Feak (2012) denominam 'fluxo', ou seja, o estabelecimento de uma clara conexão entre as ideias expressas num texto, tema abordado em ambiente presencial durante o curso. O segmento posterior, ainda no exemplo (10) 'partimos dos seguintes conceitos', com igual propósito, estabelece a conexão com o enunciado seguinte, que traz os posicionamentos do autor citado.

O último Comentário (X) refere-se à observação, iniciada pela abreviatura "OBS.:", após a linha 46, feita pelo aluno sobre sua impossibilidade em desenvolver a base teórica antes de definir os autores que consultará, numa alusão à necessidade de refletir sobre os fundamentos teóricos a adotar. Sobre essa observação, é possível observar, na reescrita final, nas linhas 89 a 95, que as escolhas foram feitas e que são bastante adequadas ao estudo proposto para o artigo, sugerindo a integração de espaços mentais e o surgimento de novas estruturas com o avanço do processo cognitivo. 
Finalizada a nossa análise, apresentamos, a seguir, uma pesquisa realizada entre alunos que participaram de cursos em que a proposta deste estudo foi aplicada, como modo de conhecer, por meio do que eles revelam ao responder a questões sobre o processo, o ponto de vista de estudantes que tenham participado de uma experiência pedagógica de produção de texto acadêmico nos dois ambientes, presencial e virtual.

\subsection{Pesquisa com alunos}

Um aspecto do conjunto das pesquisas realizadas para este estudo é de natureza etnográfica, pois contou com a observação participante do professor durante as aplicações desta proposta pedagógica de atividades combinadas em ambientes presencial e virtual com a finalidade de, por meio de procedimentos metodológicos de diagnóstico e intervenção, contribuir para o ensino de escrita acadêmica no ensino superior. Além disso, foram também elaborados questionamentos dirigidos a professores e alunos sobre os temas do ensino de produção dos gêneros acadêmicos e da interação em ambiente virtual. Conforme já mencionado na Introdução deste trabalho, essa conduta se alinha ao pensamento de MottaRoth (2011, p. 167) em relação a pesquisas de linguagem como gênero, quando essa autora indica um processo cíclico de interpretação que leve em conta a literatura de referência, o estudo dos textos, a teoria do pesquisador e o depoimento de participantes da interação.

A pesquisa junto a professores já foi descrita e analisada no Capítulo 1 deste estudo, e aquela que entrevistou alunos será apresentada a seguir. Tal opção se justifica pela colaboração que a análise desse questionamento traz para a apresentação dos resultados apontados pelo conjunto de procedimentos metodológicos adotado. Procurou-se encontrar estudantes universitários que, preferencialmente, já tivessem participado de disciplina ou curso que abordasse o tema da produção de texto acadêmico. Igualmente ao que aconteceu na pesquisa feita junto a professores, também foi utilizado um questionário do tipo 'Formulário Google', elaborado em ambiente virtual. Para conhecer o perfil e as posições dos alunos participantes, tal questionário propôs vinte e duas (22) questões fechadas e abertas, acessadas e respondidas através de um link ao referido formulário, enviado ao email ou à página da rede social do participante.

O convite foi feito de maneira bastante informal, como se pode ver na reprodução de uma postagem feita no Grupo Google dos alunos do IME-USP da disciplina FLC0474 Língua Portuguesa ao final do segundo semestre de 2012, convidando-os a participar da 
pesquisa, reproduzida no ANEXO G, da seção de ANEXOS deste trabalho. O grupo era formado por cinquenta e nove (59) membros, sendo cinquenta e oito alunos e um professor. Uma mensagem nos mesmos moldes também foi postada no ambiente virtual de aprendizagem Moodle USP Stoa, ao final do segundo semestre de 2013, para o grupo de alunos de Letras da FFLCH-USP que cursou a Disciplina FLC1261 Leitura e Produção de textos II, com vinte e um (21) participantes, sendo dezenove alunos, um professor e um monitor.

Conforme ainda se pode observar, na reprodução do email enviado a cento e um (101) professores com o convite a participarem da pesquisa, no ANEXO F, da seção de ANEXOS, além desse convite havia outro pedido: "Se for possível, por favor encaminhe a seus alunos a versão 'alunos' do questionário, via link: https://docs.google.com/forms/d/1qmgMwiccnntNk_cDKnN9TXBz3cRO2PpDYojqQhYXus/viewform.” Tais informações justificam a incerteza em relação a quantos alunos de fato receberam o convite para responder à pesquisa, porém certamente foram mais do que o total de setenta e sete (77) dos membros dos grupos virtuais mencionados.

O fato de haver entrevistados da área de Letras de outros centros universitários, como a Universidade Federal de Uberlândia (UFU), a Universidade do Estado do Rio de Janeiro (UERJ), a Universidade Estadual de Campinas (UNICAMP), também evidencia que, embora a grande maioria dos alunos que responderam ao questionário tenha declarado ser da Universidade de São Paulo (USP), alunos de outras universidades também tomaram conhecimento da pesquisa, provavelmente através de seus professores, que atenderam ao apelo da mensagem que lhes foi enviada. Quando ocorreu o encerramento da pesquisa, em abril de 2014, vinte (20) alunos dessas diferentes universidades haviam participado.

Esse convite mais direcionado aos estudantes da Universidade de São Paulo, do IMEUSP e da FFLCH-USP teve como resultado uma maior participação de alunos dessa instituição, da ordem de setenta e cinco por cento $(75 \%)$, em relação aos de outras universidades, vinte e cinco por cento (25\%). Embora tenhamos conhecimento de que as respostas obtidas reflitam em boa parte o que acontece particularmente na Universidade de São Paulo, consideramos sua relevância para nosso estudo visto que o perfil que buscamos foi de alunos que preferencialmente tivessem tido experiência com aprendizagem combinada, como é o caso dos grupos que acompanhamos.

Como ocorreu na pesquisa junto aos professores, também na pesquisa entre os alunos houve questões de identificação para informar 'Nome', 'Email' ou 'Sexo' (Questões 1, 2 e 3), que não serão referidas na descrição e na análise, por questão de sigilo da identificação, 
assegurado a todos os participantes. Todavia, para garantir que cada conjunto de informações tenha sido fornecido pelo mesmo entrevistado, também foram atribuídos a cada um deles uma sigla e um número, portanto temos RA1, RA2, RA3... respectivamente a cada Respondente Aluno, sendo utilizado termo RA em substituição a Respondente Aluno daqui em diante. Com o intuito de facilitar a consulta às informações obtidas, todas as respostas estão transcritas na seção ANEXOS deste trabalho, no ANEXO I.

Segue a lista das questões propostas aos alunos, com a respectiva caracterização de sua modalidade: questões que pedem respostas abertas, por meio de palavras, sentenças ou parágrafos, ou questões com múltiplas alternativas previamente elaboradas, consideradas de resposta 'fechada'.

1. Nome (Resposta aberta)

2. Email (Resposta aberta)

3. Sexo (Alternativas: Feminino / Masculino)

4. Grupo etário a que pertence (Alternativas: 17 a 20 anos / 21 a 25 anos / 26 a 29 anos / 30 a 39 anos / 40 a 49 anos / 50 a 59 anos / 60 anos ou mais)

5. Universidade em que estuda (Resposta aberta)

6. Nome do curso que faz (Resposta aberta)

7. Ano de ingresso nesse curso (Resposta aberta)

8. Seu curso é (Alternativas: Totalmente presencial / Totalmente a distância / parte presencial e parte a distância)

9. No curso que frequenta no momento, você já fez ou está fazendo disciplina que envolva o ensino de produção de texto? (Alternativas: Sim / Não)

10. Em caso de resposta positiva à pergunta anterior, responda às questões que seguem. Qual é o nome da disciplina que você cursa/cursou? (Resposta aberta)

11. Enumere, resumidamente, as atividades que você desenvolve/desenvolveu nessa disciplina. (Resposta aberta)

12. O ensino de produção de texto acadêmico (ou artigo científico) fez/faz parte das atividades desenvolvidas nessa disciplina? (Alternativas: Sim / Não) 
13. Se você respondeu "Sim", você crê que aprender a produzir textos acadêmicos possa contribuir na promoção da aprendizagem de outras disciplinas? Por quê? (Resposta aberta)

14. O professor ou monitor responsável pela disciplina utilizou meios digitais para se comunicar com os alunos fora do horário de aula presencial? (Alternativas: Sim / Não)

15. Em caso de resposta positiva à questão anterior, quais? (Alternativas: Grupo de emails do correio eletrônico convencional / Grupo do Google / Página no Facebook / Ambiente educacional do tipo plataforma Moodle / Outro: Resposta aberta)

16. Você enfrenta algum tipo de problema por conta da utilização desses ambientes virtuais? (Alternativas: Sim / Não)

17. Em caso positivo, qual/quais? (Resposta aberta)

18. Você avalia positiva ou negativamente a utilização do ambiente virtual? (Alternativas: Positivamente / Negativamente)

19. Você acredita que todos participam igualmente das atividades desenvolvidas no ambiente virtual? (Alternativas: Sim / Não)

20. Você e/ou seus colegas tiveram dificuldades no acesso ao ambiente virtual? Comente. (Resposta aberta)

21. Quanto aos resultados em termos de aprendizagem, você acredita que o curso e as atividades em ambiente virtual contribuíram para a construção de conhecimentos novos para você? (Alternativas: Sim / Não)

22. Qual é a sua opinião sobre o ambiente virtual como canal de apoio ao ensino? Comente. (Resposta aberta)

É possível dizer que a pesquisa enviada aos alunos engloba aspectos quantitativos e qualitativos - pois dele constam onze (11) questões 'fechadas' (números: três, cinco, oito, nove, doze, catorze, quinze, dezesseis, dezoito, dezenove, vinte e um), que propõem respostas prontas de múltipla escolha, e onze (11) questões 'abertas' (números: um, dois, quatro, seis, sete, dez, onze, treze, dezessete, vinte, vinte e dois), que permitem ao participante produzir as próprias respostas - embora não haja um envolvimento muito grande entre pesquisador e pesquisados para que estes desenvolvam mais suas respostas. Em comparação ao número de dez professores que respondeu à primeira pesquisa (Capítulo 1), foi considerado bastante 
adequado o número de vinte (20) alunos que efetivamente participaram da pesquisa. Ainda assim, é um número pequeno para que se faça a extrapolação de dados para uma população maior; nessa direção, também optamos por fazer uma análise qualitativa das respostas.

O item 4.3.1, a seguir, contém algumas representações gráficas dos números obtidos em respostas a questões com alternativas, sua análise e ainda a análise de respostas às questões abertas.

4.3.1 Tabulação de resultados, gráficos e análises de questões propostas aos alunos

Quando as questões propostas assim o permitiram, por admitirem apenas respostas escolhidas entre alternativas já definidas, foram elaborados gráficos que representam as quantidades de respostas obtidas para cada alternativa. Após tais gráficos, os resultados são analisados e, seguindo a ordem das questões, há também análises de respostas produzidas pelos entrevistados, referentes a perguntas abertas. Para garantir o sigilo dos participantes, as questões relativas à sua identificação (Questão 1: Nome, Questão 2: Email, Questão 3: Sexo) não farão parte dessa tabulação de resultados, iniciada a partir da Questão 4.

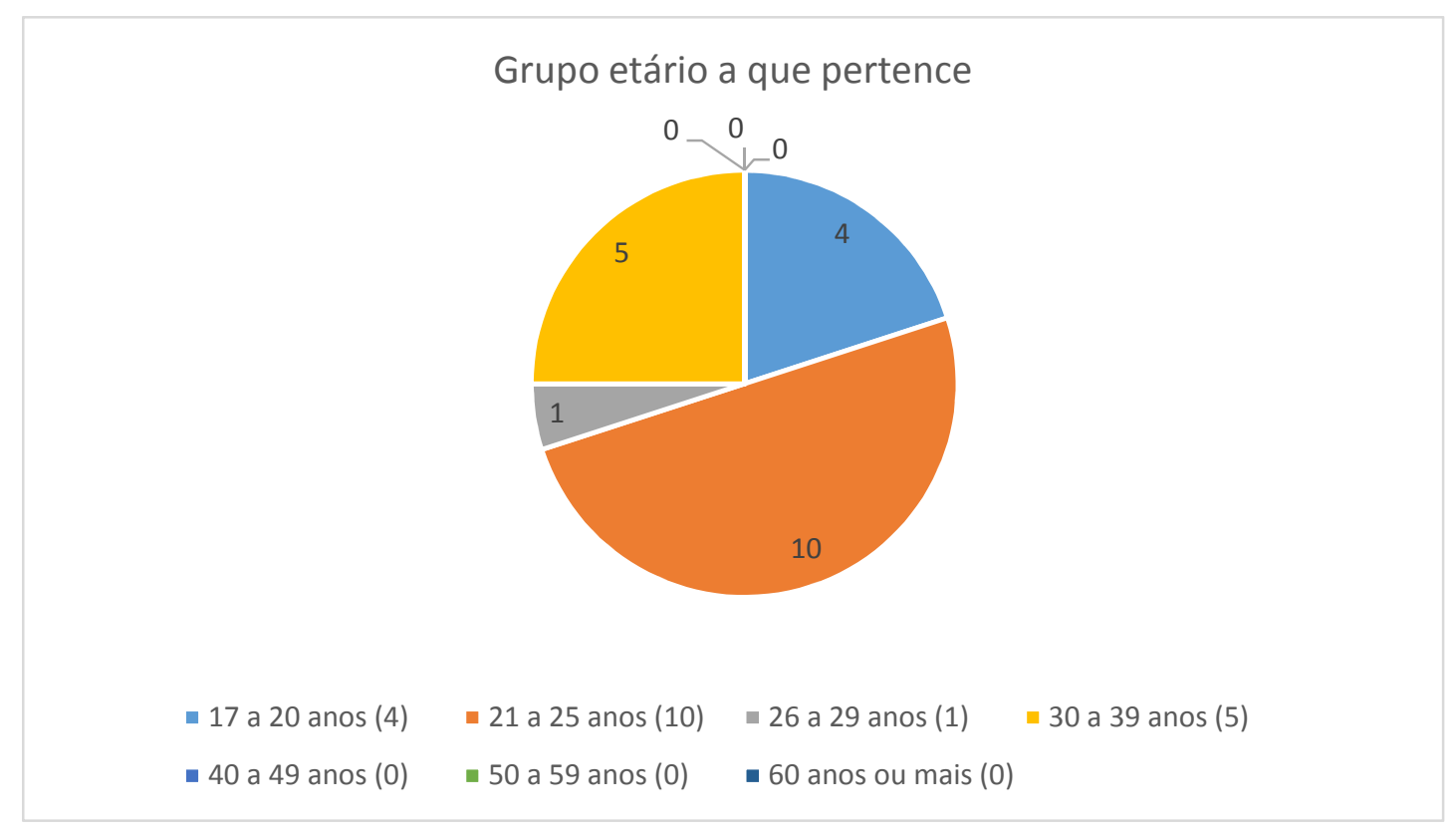

Gráfico 10 - Questão 4: Grupo etário a que pertence 
O gráfico referente ao Grupo etário (Questão 4) contribui com a identificação dos participantes ao informar que eles pertencem, principalmente, ao grupo etário de '21 a 25 anos' (50\%), mas que também há alguns nos grupos de '30 a 39 anos' (25\%), de '17 a 20 anos' (20\%) e de '26 a 29 anos' (5\%). Não há respondentes de 40 anos ou mais.

O gráfico que segue, relativo à Questão 5 sobre a universidade frequentada, informa que há RAs da Universidade do Estado do Rio de Janeiro - UERJ (10\%), da Universidade Federal de Uberlândia - UFU (10\%) e da Universidade Estadual de Campinas - UNICAMP (5\%). A alta porcentagem de participantes (75\%) que estudam na Universidade de São Paulo - USP confirma a expectativa de que os alunos dos cursos em que houve aplicações desta proposta de ensino para o gênero artigo científico, convidados a se posicionarem sobre sua experiência, aceitaram o convite e constituíram a grande maioria dos entrevistados.

\section{Universidade em que estuda}

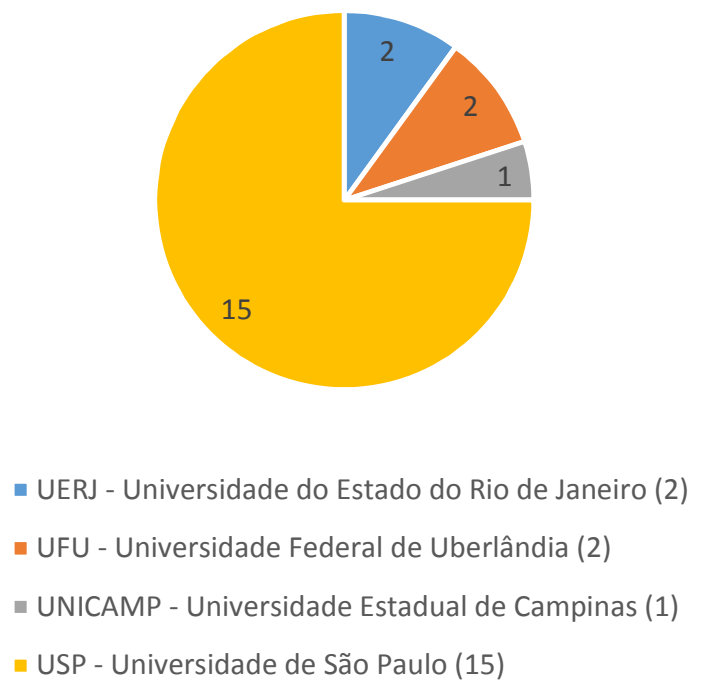

Gráfico 11 - Questão 5: Universidade em que estuda

Os dados presentes no gráfico da Questão 6, a seguir, também confirmam a porcentagem bastante equilibrada da participação de RAs de cursos da área de Letras (45\%) e da área de Estatística (55\%). Logo depois, o gráfico da Questão 7, traz a informação de que 
$60 \%$ dos alunos estavam no início de sua graduação, pois haviam ingressado em seu curso em 2012, pelo menos um ano antes da participação na pesquisa.

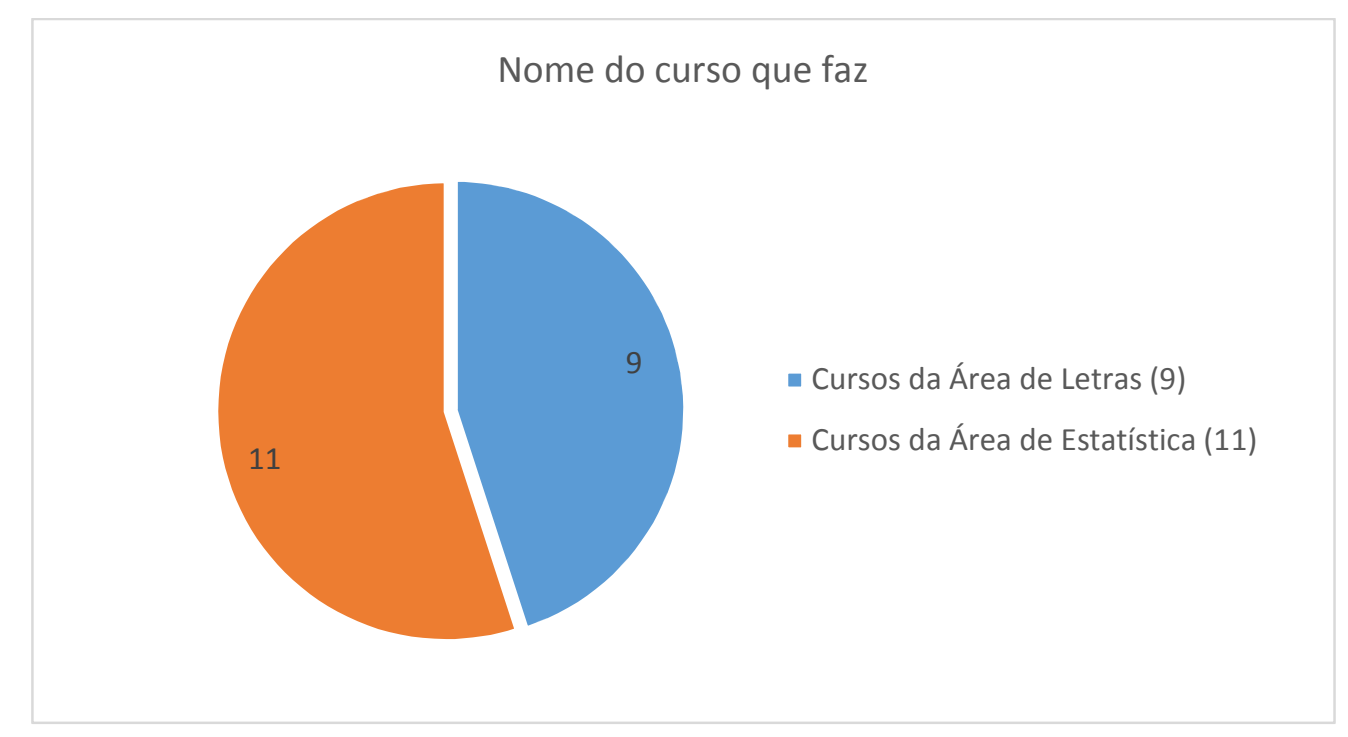

Gráfico 12 - Questão 6: Nome do curso que faz

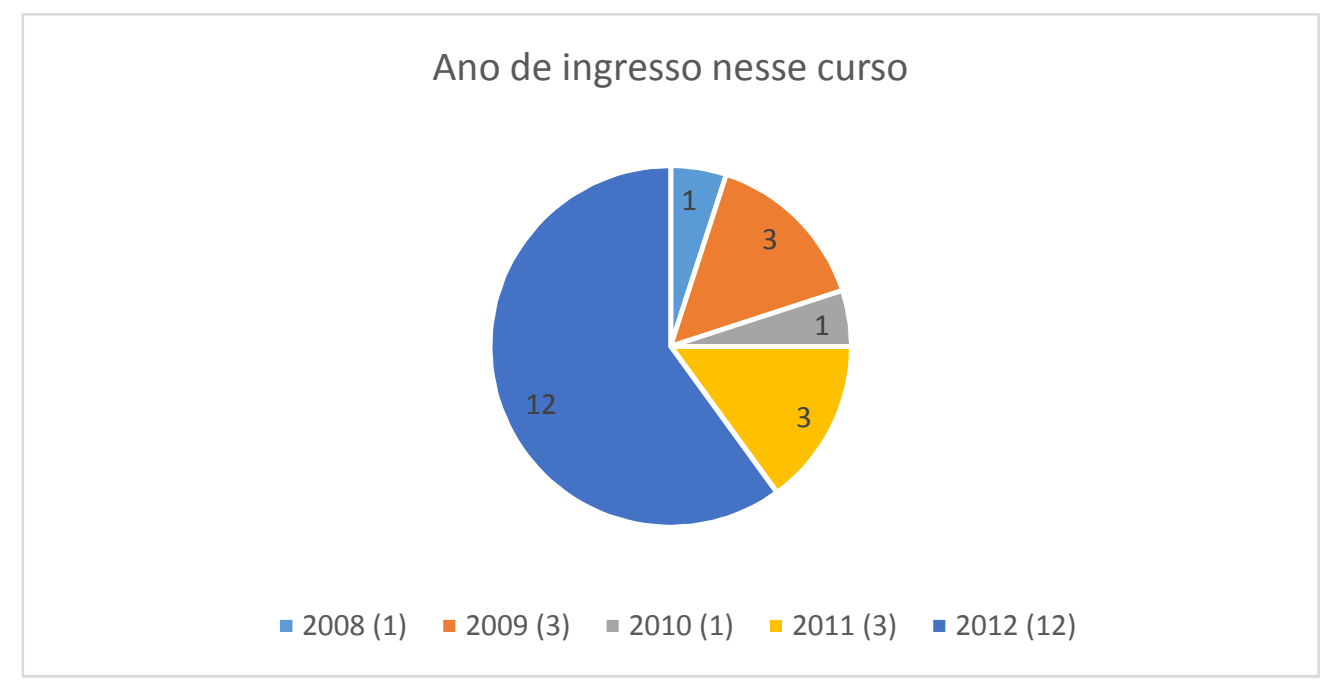

Gráfico 13 - Questão 7: Ano de ingresso nesse curso

As respostas obtidas na Questão 8, representadas a seguir, referem-se à percepção dos respondentes quanto à diferenciação entre ensino presencial, que consideramos as atividades que acontecem em sala de aula por meio de interação face a face, e ensino a distância, que 
para esta pesquisa significa o conjunto de atividades realizadas por meio de ambiente virtual. Volta-se ao tema do ambiente virtual apenas a partir da Questão 14, quando se coloca a possibilidade de o professor ou monitor responsável pela disciplina utilizar meios digitais para se comunicar com os alunos fora da aula presencial.

É interessante observar que, conforme o gráfico da Questão 8, 100\% dos entrevistados escolheu a alternativa 'Totalmente presencial', enquanto que, em resposta à Questão 14, que coloca a mesma questão de modo diferente, num outro momento do questionário, $95 \%$ dos estudantes responderam afirmando que o professor ou monitor utilizou meios digitais para se comunicar com os alunos fora do horário de aula. Respostas a outras questões, principalmente à Questão 22, analisada mais detalhadamente no final, indicam que não houve apenas 'comunicação', mas ações, como o mencionado "contato com a monitora do curso para esclarecimento de dúvidas bem como orientação de trabalhos", entre outras, o que configuraria que atividades didáticas também foram desenvolvidas em ambiente virtual, em combinação com as aulas presenciais.

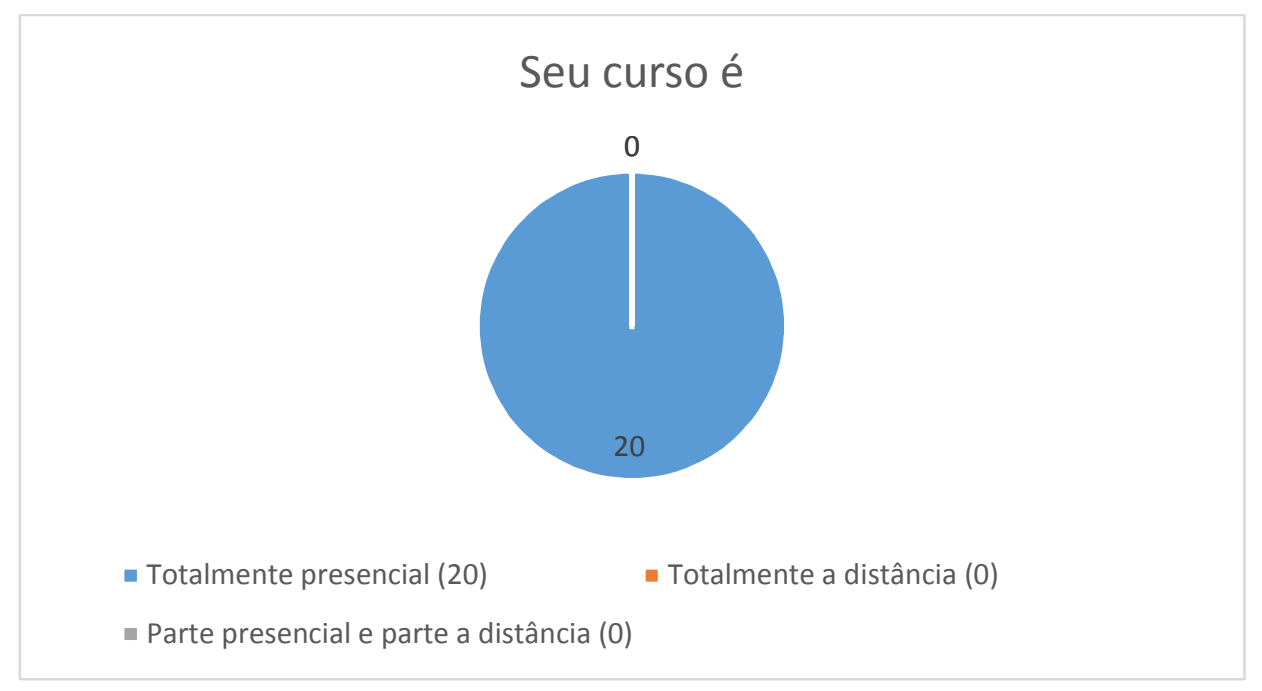

Gráfico 14 - Questão 8: Seu curso é 
As Questões 9 a 13 referem-se ao ensino de produção textual e à produção de texto acadêmico ou artigo científico em particular. Nos gráficos que as representam a seguir, podemos respectivamente observar que $95 \%$ dos RAs declara que seu curso ou disciplina envolve/envolveu o ensino de produção de texto (Questão 9); que, entre as disciplinas cursadas (Questão 10), prevalecem aquelas nomeadas como Língua Portuguesa (50\%) e Leitura e Produção de Textos (35\%), sobre as designadas por Metodologia (10\%); e que, em $80 \%$ dos casos, o ensino de produção de texto acadêmico ou artigo científico faz/fez parte das atividades desenvolvidas (Questão 12).

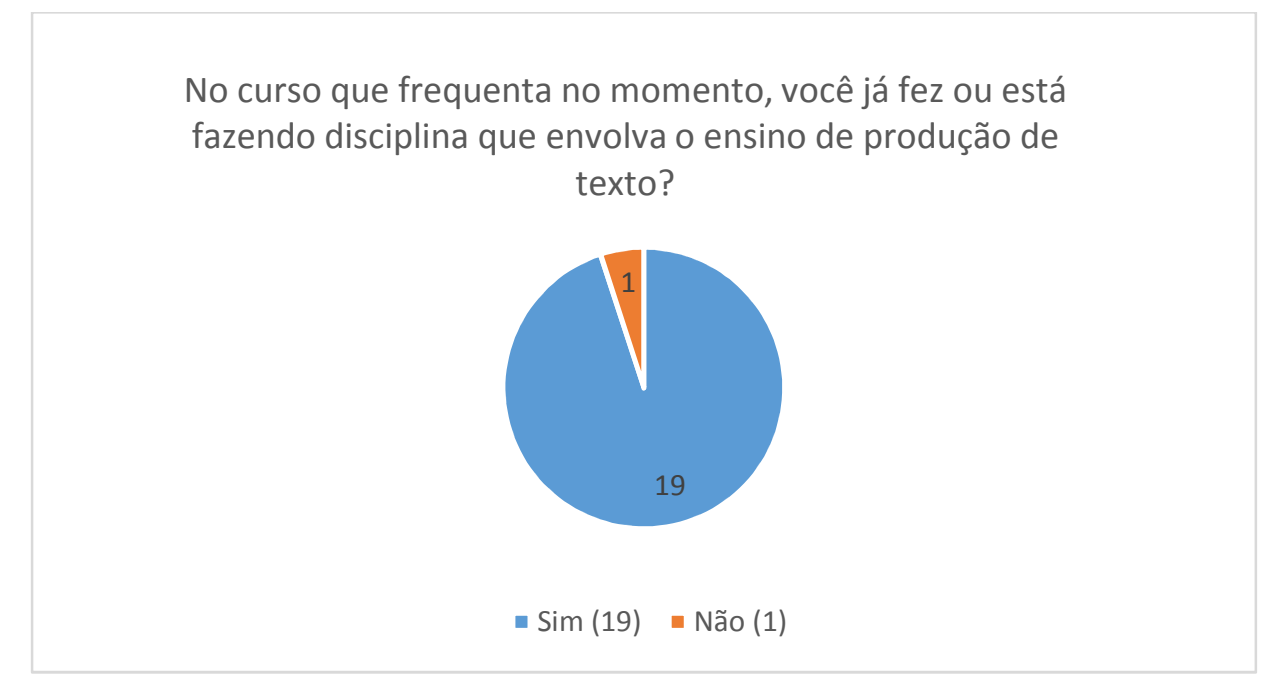

Gráfico 15 - Questão 9: No curso que frequenta no momento, você já fez ou está fazendo disciplina que envolva o ensino de produção de texto?

Em caso de resposta positiva à pergunta anterior, responda às questões que seguem. Qual é o nome da disciplina que você cursa/cursou?

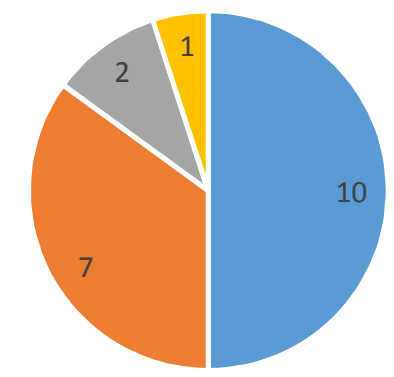

- Língua Portuguesa (10) - Leitura e Produção Textual (7) - Metodologia (2) - Não respondeu (1)

Gráfico 16 - Questão 10: Em caso de resposta positiva à pergunta anterior, responda às questões que seguem. Qual é o nome da disciplina que você cursa/cursou? 
O ensino de produção de texto acadêmico (ou artigo científico) fez/faz parte das atividades desenvolvidas nessa disciplina?

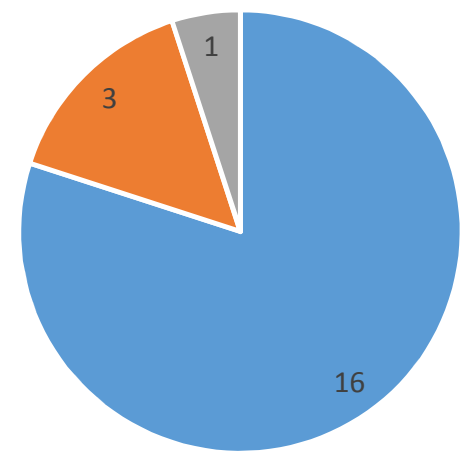

- Sim (16) $\quad$ Não (3) Não respondeu (1)

Gráfico 17 - Questão 12: O ensino de produção de texto acadêmico (ou artigo científico) fez/faz parte das atividades desenvolvidas nessa disciplina?

As respostas referentes à Questão 11: Enumere, resumidamente, as atividades que você desenvolve/desenvolveu nessa disciplina. , de resposta aberta, foram transcritas abaixo como forma de confirmação de que os respondentes de fato desenvolveram, nas disciplinas que cursaram, atividades relacionadas ao ensino de leitura e produção escrita de diversos gêneros acadêmicos, entre os citados: "artigo científico" (RA2, RA4, RA7, RA8, RA11, RA12, RA13, RA14, RA15); "resumo" (RA4, RA8, RA10); “resenha” (RA4, RA20); "relatório" (RA6, RA8, RA9); "pôster” (RA6, RA10). Tal condição os habilita a responder à Questão 13, cujas respostas também vêm reproduzidas a seguir, com as respectivas análises. ${ }^{55}$

RA1 Leitura e produção de textos acadêmicos.

RA2 Leitura e interpretação de textos, Produção de artigo científico RA3 -

RA4 A principal meta consistiu em escrever um artigo científico. Ao longo do curso foram realizadas atividades com a finalidade de conhecer técnicas para a redação de um artigo, como escrever resumos, resenhas e foram analisados textos científicos para se familiarizar com a linguagem e a estrutura.

55 Todas as transcrições correspondem aos textos originais, conforme produzidos pelos respondentes. A transcrição completa de todas as respostas está no ANEXO I da seção de ANEXOS. 
RA5 Em suma, o objetivo da disciplina era desenvolver nos alunos a capacidade de elaboração de textos científicos.

RA6 Desenvolvimento de Relatório Estatístico com base num projeto do CEA (Centro de Estatística Aplicada), Desenvolvimento de um pôster baseado no mesmo projeto.

RA7 Leitura de textos e atividades voltadas à produção de artigos científicos.

RA8 Relatórios, Produção de Textos, Resumos, Artigos

RA9 Aprendi como fazer um relatório científico

RA10 Realização de resumo e introdução para um trabalho acadêmico, realização de apresentação (estilo powerpoint) e de um pôster ambos acadêmicos também.

RA11 Análise de artigos científicos provenientes da área de Ciência da Computação, Produção de artigo científico em tema da minha área (Estatística), Noções acerca da produção de textos: coesão e coerência, paráfrase e citação, competências linguísticas, entre outras.

RA12 Estudamos linguística textual, Estudamos estratégias para a construção de um texto, Estudamos as normas da ABNT, Realizamo a produção de um artigo acadêmico com acompanhamento contínuo.

RA13 Quanto à forma: desenvolver os textos a partir das normas da ABNT para trabalhos científicos, Quanto ao conteúdo: analisar questões de coesão e coerência, intertextualidade e como argumentar em artigo científico.

RA14 Escrevemos um artigo cientifico

RA15 desenvolvimento de técnicas para produção de artigo científico, atividades via moodle (à distância), orientação para trabalho dada pela professora e pela monitora do curso

RA16 1 - desenvolvimento de estruturação modelo de trabalho de Iniciação Científica, 2 produção textual dentro do formato proposto, 3 - normas ABNT, 4 - considerações teóricas acerca da produção do projeto, 5 - seleção de arcabouço teórico

RA17 PESQUISA, LEITURA, MONTAGEM DE TEXTO.

RA18 Produção de alguns gêneros textuais.

RA19 Discussões teóricas, Provas

RA20 -RESENHA CRÍTICA， -REESCRITURA DE CONTO, -PRODUÇÃO E PARÁGRAFO PADRÃO, -PRODUÇÃO DE UMA NOTÍCIA DE JORNAL, -ARTIGO SOBRE UM TEXTO, -CRÔNICA

Questão 13: Se você respondeu "Sim", você crê que aprender a produzir textos acadêmicos possa contribuir na promoção da aprendizagem de outras disciplinas? Por quê?

RA1 Outras disciplinas exigem a produção de textos acadêmicos, sendo necessária sua aprendizagem.

RA2 Sim, porque facilita a leitura e compreensão dos textos científicos das outras disciplinas - mesmo sendo de exatas, a estrutura permanece a mesma. Auxilia também na estruturação de um pensamento lógico, baseado em argumentos da literatura e não apenas em conjecturas. 
RA3 -

RA4 Sim porque auxilia no desenvolvimento de atividades em que a produção de textos acadêmicos é necessária para explicar determinado estudo.

RA5 Com certeza. Em todos os níveis de ensino, faz-se necessária a produção de textos científicos, com boa base teórica e argumentação.

RA6 -

RA7 Não. O foco desta graduação é totalmente matemático.

RA8 Porque proporciona uma série de ferramentas uteis para ser aplicada a outras áreas do conhecimento!

RA9 Sim, pois ajuda bastante no desenvolvimento da área acadêmica do curso.

RA10 Sim, pois, por exemplo, no curso de estatística mesmo, temos uma matéria no quarto ano que temos que elaborar um texto desse tipo, então é de grande ajuda aprender o quanto antes. Essa atividade é ainda mais importante para aqueles que desejam seguir carreira no meio acadêmico.

RA11 Julgo que não há contribuição na aprendizagem das disciplinas em si, no caso do meu curso; porém, a experiência técnica adquirida foi (e será) valiosa para a vida pessoal e profissional.

RA12 Acredito que o aprendizado da produção de textos acadêmicos contribui com outras disciplinas. Primeiramente, porque existe uma norma para construir trabalhos acadêmicos que deve ser seguida na maioria das matérias, logo estaríamos aptos para a produção desses trabalho. Em segundo lugar, aprender a produzir um texto acadêmico ajuda no desenvolvimento e na elaboração das ideias em torno de uma análise.

RA13 Sim, porque treinar produção de texto acadêmico colabora inclusive a organizar o conteúdo oriundo de qualquer outra disciplina.

RA14 Sim, pq nos auxilia a saber escrever melhor os trabalhos de outras disciplinas.

RA15 Sim, a partir disso é possível aprimorar a escrita, adequando trabalhos e outras atividades ao meio acadêmico.

RA16 Com certeza. A confiança que a produção de um texto acadêmico dá é muito positivo. Além de melhorar a escrita, a produção, a seleção de corpus para análise, arcabouço teórico.

RA17 SEM DUVIDAS. FOI DE FUNDAMENTAL IMPORTANCIA. ACREDITO AINDA QUE ESTA MATERIA DEVERIA ESTAR NO SEGUNDO SEMESTRE E NAO NO TERCEIRO.

RA18 -

RA19 -

RA20 SIM. DEVIDO AO FATO DO INDIVÍDUO SE TORNAR MAIS CRÍTICOS E TER HABILIDADE PARA DISCUTIR E PRODUZIR DIFERENTES TIPOS DE TEXTOS. ISSO DE UM MODO GERAL CONTRIBUI PARA A FLUIDEZ DA APRENDIZAGEM DE OUTRAS DISCIPLINAS. 
Com a exceção de RA3, RA6, RA18 e RA19 que deixaram de responder, apenas RA7 disse "Não", justificando que o foco de seu curso era totalmente matemático. RA11 reconheceu que a experiência é valiosa para a futura vida profissional, embora creia que não tenha havido contribuição para as outras disciplinas. É possível dizer que essa posição, apesar da negativa, reconhece o valor do estudo.

Por outro lado, quinze respondentes (75\%) concordam com o fato de que aprender a produzir textos acadêmicos auxilia práticas de outras disciplinas (RA1, RA2, RA4, RA8, RA9, RA12, RA13, RA14), ajuda a aprimorar a escrita (RA14, RA15, RA16), a estruturar o pensamento (RA2), e torna-os mais críticos e aptos a analisar, discutir, argumentar e produzir outros textos. Há ainda entre esses respondentes a menção à produção de um trabalho obrigatório para a conclusão da graduação e de outros trabalhos acadêmicos, atividade que se beneficiará das competências linguísticas desenvolvidas nas aulas de produção de texto acadêmico, segundo os entrevistados RA10 e RA12.

Vindo ao encontro das proposições do presente estudo, quanto à relação de benefício mútuo que se dá entre o desenvolvimento de competências linguísticas, discursivas e textuais e a construção dos conhecimentos acadêmicos em geral, a grande maioria dos Respondentes Alunos reconhece que aprender a produzir textos acadêmicos pode ser um facilitador da aprendizagem acadêmica em geral. Tal reconhecimento é um indicativo de que o desenvolvimento de práticas de ensino nessa área pode ser intensificado, pois elas têm grandes chances de serem bem aceitas pelos aprendizes, visto que esses reconhecem a possibilidade de aplicação dessa experiência com produção textual tanto na universidade como em outros campos de atuação.

As Questões 14 a 22 abordam o tema do ambiente virtual: se foi utilizado durante o curso (Questão 14), quais foram utilizados (Questão 15), se houve e quais foram as dificuldades nessa utilização (Questões 16, 17, 19 e 20) e qual o posicionamento do entrevistado quanto à contribuição do ambiente virtual para construção de novos conhecimentos (Questão 21) e seu uso como canal de apoio ao ensino (Questão 22).

Os gráficos seguintes, relativos às Questões 14, 15, 16, 18, 19 e 20 ${ }^{56}$, confirmam a atitude bastante positiva dos estudantes pesquisados quanto ao uso do ambiente virtual, praticamente sem dificuldades de acesso declaradas, facilidade que também observam quanto

${ }^{56}$ A Questão 17 não foi respondida por nenhum participante, visto que deveriam fazê-lo somente em caso de resposta positiva à questão anterior, sobre enfrentar problemas na utilização de ambientes virtuais, o que não aconteceu. 
aos colegas, apesar de considerarem que nem todos tenham participado igualmente nas atividades realizadas a distância (Questão 19). Tais informações parecem apoiar nossa posição de que o uso dos ambientes virtuais como colaboradores nas questões de ensino pode ser bem aceito pelos estudantes, visto que, na maioria dos casos, eles dominam tal uso e reconhecem a importância do ensino por esse meio.

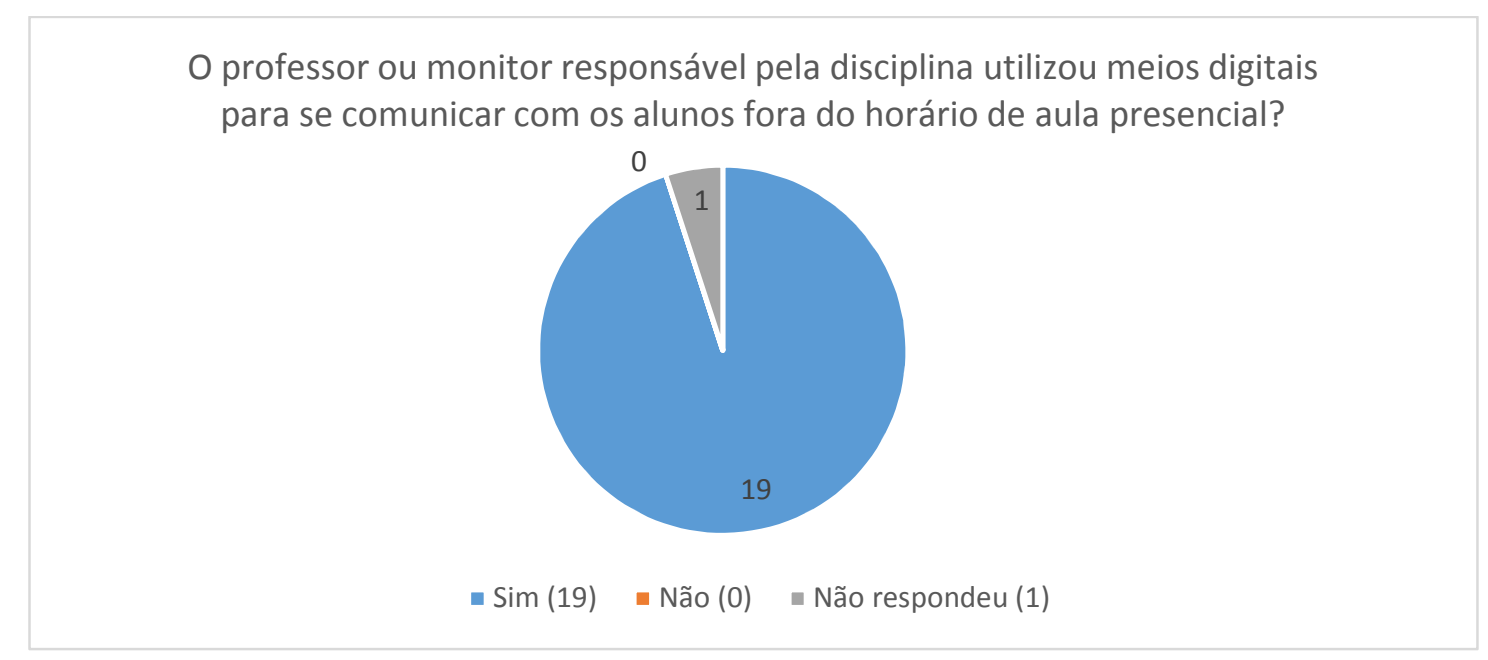

Gráfico 18 - Questão 14: O professor ou monitor responsável pela disciplina utilizou meios digitais para se comunicar com os alunos fora do horário de aula presencial?

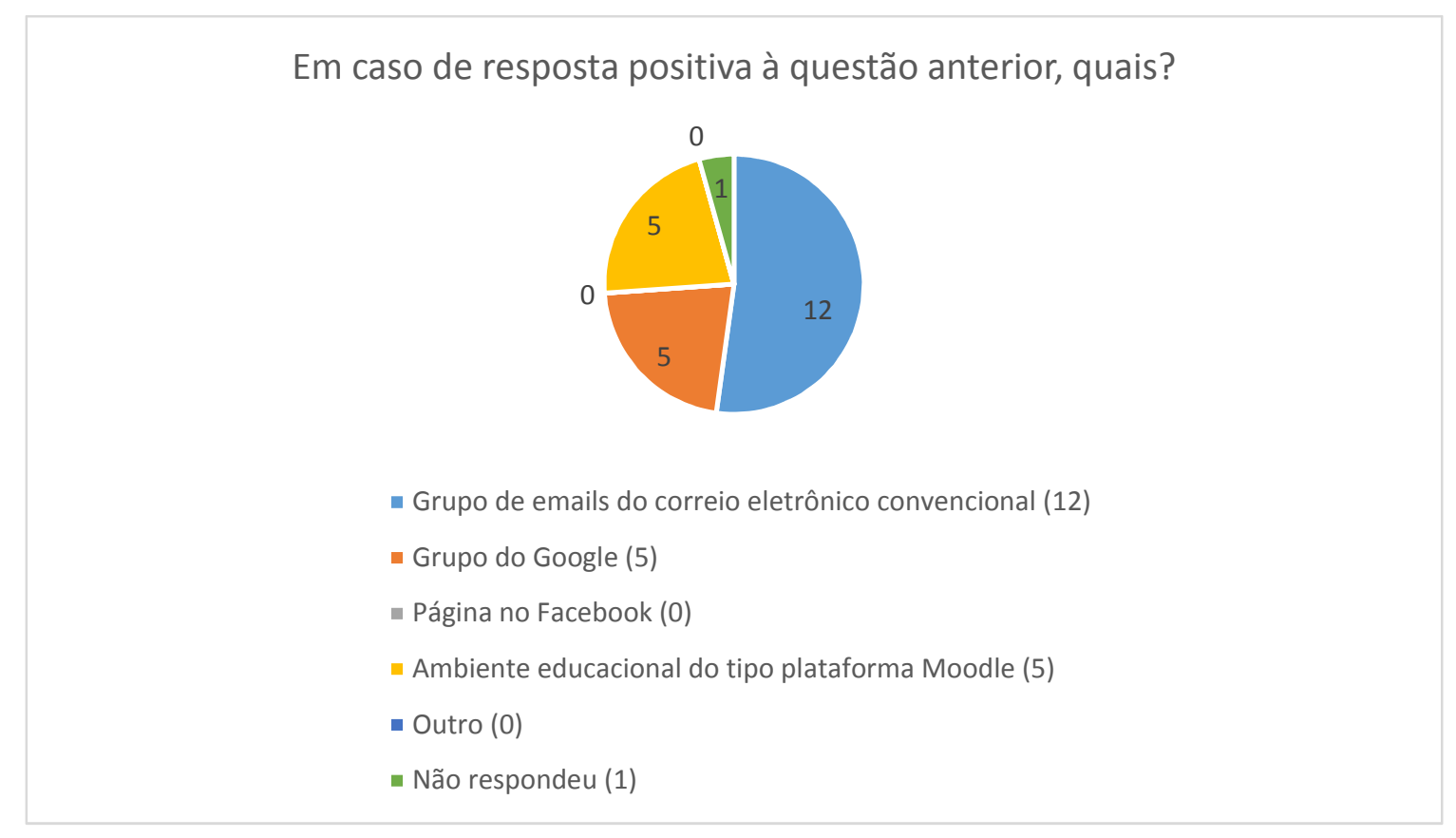

Gráfico 19 - Questão 15: Em caso de resposta positiva à questão anterior, quais?

Obs.: Era possível escolher mais de uma resposta. 
Você enfrenta algum tipo de problema por conta da utilização desses ambientes virtuais?

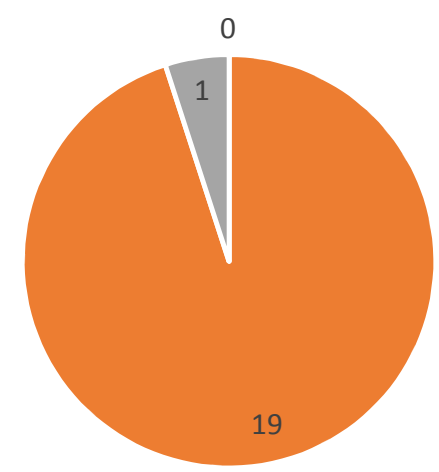

- Sim (0) - Não (19) — Não respondeu (1)

Gráfico 20 - Questão 16: Você enfrenta algum tipo de problema por conta da utilização desses ambientes virtuais?

Você avalia positiva ou negativamente a utilização do ambiente virtual?

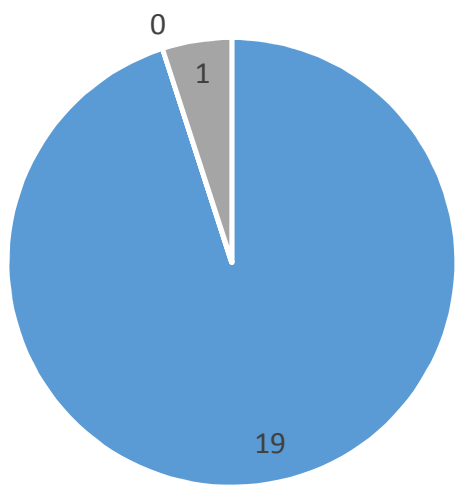

- Positivamente (19) - Negativamente (0) - Não respondeu (1)

Gráfico 21 - Questão 18: Você avalia positiva ou negativamente a utilização do ambiente virtual? 
Você acredita que todos participam igualmente das atividades desenvolvidas no ambiente virtual?

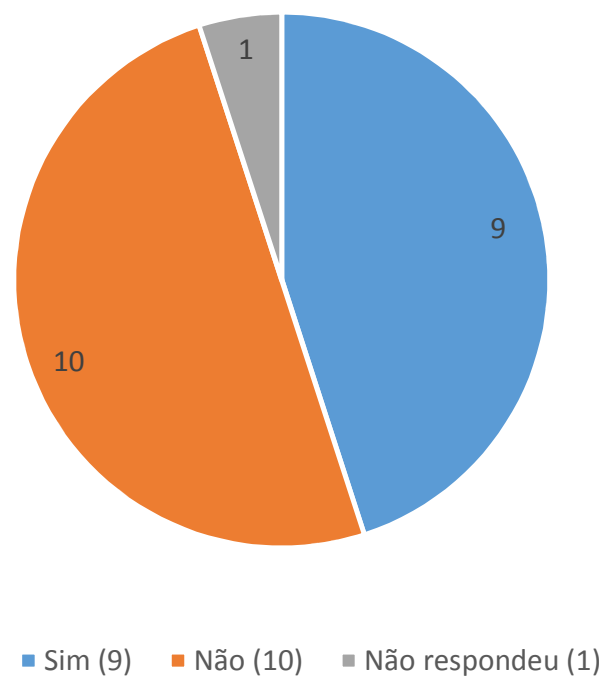

Gráfico 22 - Questão 19: Você acredita que todos participam igualmente das atividades desenvolvidas no ambiente virtual?

Você e/ou seus colegas tiveram dificuldades no acesso ao ambiente virtual? Comente.

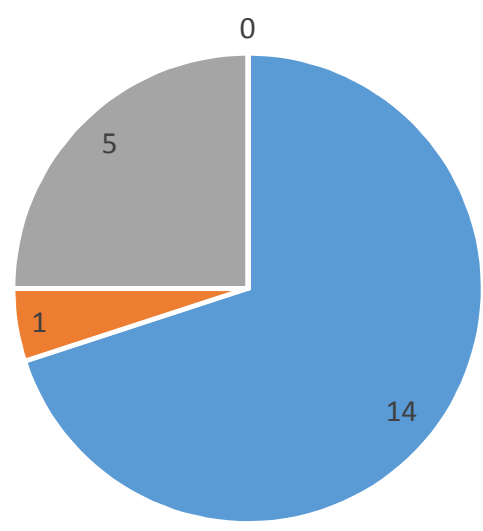

- Respostas com teor negativo (14) = Resposta positiva (1) = Não responderam (5) =

Gráfico 23 - Questão 20: Você e/ou seus colegas tiveram dificuldades no acesso ao ambiente virtual? Comente. 
Os comentários feitos pelos respondentes, quando houve, estão reproduzidos nas respostas abaixo:

RA1 Não.

RA2 Não, foi bem fácil a comunicação com a professora e entrega de trabalhos.

RA3 -

RA4 Não foram enfrentadas dificuldades.

RA5 Não. No geral, os meus colegas tem acesso ao ambiente virtual, sem dificuldades.

RA6 Não, há computadores com acesso à internet na faculdade.

RA7 a turma era nova, todos estavam acostumados ao ambiente virtual.

RA8 Não

RA9 Não

RA10 -

RA11 Não tive dificuldades. Não tomei conhecimento, também, de dificuldades alheias.

RA12 "Tive dificuldades a principio com o moodle, para entender seu funcionamento e acredito que esta seja uma dificuldade geral. Porém, pessoalmente, depois que compreendi o funcionamento da plataforma não tive mais dificuldades."

RA13 Não tive problemas com a plataforma.

RA14 Não.

RA15 -

RA16 Não, mas prefiro a aula expositiva, com considerações frente a frente.

RA17 NÃO. ACREDITO QUE O AMBIENTE VIRTUAL FACILITA O APRENDIZADO. POREM MUITAS VEZES ISSO É CONFUNDIDO PELOS ALUNOS COMO MAIS TRABALHO.

RA18 -

RA19 -

RA20 DIANTE DO MEU POSICIONAMENTO ACREDITO QUE NÃO, ATÉ MESMO PELO FATO DO AMBIENTE VIRTUAL PROPORCIONAR DE CERTA FORMA MAIS FACILIDADE DE COMUNICAÇÃO ENTRE AS PESSOAS.

Reproduzidas no gráfico seguinte, as respostas afirmativas à Questão 21, sobre resultados em termos de aprendizagem, indicam que a grande maioria dos participantes da pesquisa $(75 \%)$ considera que o curso sobre produção de texto acadêmico que incluiu atividades realizadas em ambiente virtual foi eficiente quanto ao objetivo de construir novos conhecimentos. 


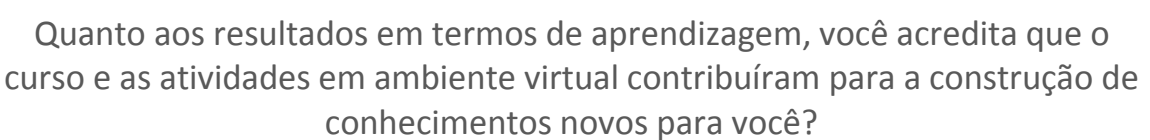

conhecimentos novos para você?

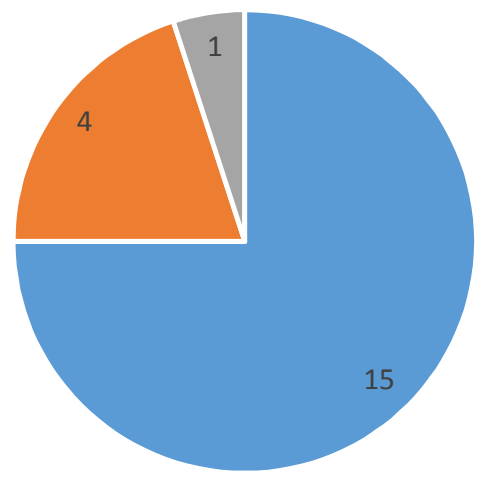

—Sim (15) — Não (4) — Não respondeu (1)

Gráfico 24 - Questão 21: Quanto aos resultados em termos de aprendizagem, você acredita que o curso e as atividades em ambiente virtual contribuíram para a construção de conhecimentos novos para você?

Finalmente, como as respostas à Questão 22 são bastante relevantes para esta pesquisa, elas estão transcritas a seguir, acompanhadas por sua análise.

Questão 22: Qual é a sua opinião sobre o ambiente virtual como canal de apoio ao ensino? Comente.

RA1 Considero muito bom por facilitar o compartilhamento de materiais didáticos.

RA2 Atualmente é o meio mais fácil e eficiente de auxílio ao ensino pois seu uso é disseminado entre praticamente todos os alunos do meu curso.

RA3 (não respondeu)

RA4 O ambiente virtual auxilia na comunicação rápida e em grande escala.

RA5 Além de ser muito importante a inserção das fases do aprendizado nos meios virtuais, esse ato facilita muitos processos, como o transporte de informações sobre o curso de maneira rápida e eficiente.

RA6 Apoio o uso do ambiente virtual como auxílio ou feedback das aulas, não como parte do ensino em si.

RA7 Totalmente favorável.

RA8 Beneficio para a aquisição de material e de informações a serem transmitidas! 
RA9 O ambiente virtual é bom, pois deixa a aula mais interessante e facilita bastante a visualização dos gráficos.

RA10 Apoio essa utilização, pois estreita o caminho professor-aluno. E também, no meu caso, as aulas eram só uma vez por semana, então se alguma dúvida surgisse não precisávamos esperar 1 semana até a próxima aula e etc.

RA11 Considero o ambiente virtual um importante aliado do ensino, sobretudo em nossos tempos; porém, não deve ser exclusivo. As aulas presenciais são, ainda, essenciais.

RA12 Acredito que seja necessário que o ensino acompanhe o desenvolvimento da tecnologia. Porém, não acredito em um ensino que seja feito somente a distância. Penso que os dois devem caminhar em conjunto.

RA13 Acho que é uma maneira dos alunos interagirem e, por vezes, dúvidas de alguns pode ser de todo mundo.

RA14 Em tempos de internet, é um modo inteligente de aprimorar o estudo e conversar com os educadores.

RA15 O ambiente virtual foi bastante importante para ter acesso a textos, contato com a monitora do curso para esclarecimento de dúvidas bem como orientação de trabalhos, complementando o que foi desenvolvido em sala de aula.

RA16 Gosto do meio virtual como 'auxílio' no aprendizado. Mas não acredito no ambiente virtual substituindo a sala de aula.

RA17 ACREDITO QUE SEJA POSITIVO. POREM ALGUNS PROFESSORES EXAGERAM EM SEU USO. COMO VOCE MESMO DISSE "APOIO". ISTO NAO SIGNIFICA "OVER WORK".

RA18 Positiva. No mundo atual é quase impossível não usar o ambiente virtual.

RA19 O sucesso de um ambiente virtual com fins educacionais depende da qualidade das interações que ali se desenvolverão tanto entre professor e alunos quanto entre alunos. Daí a necessidade, a meu ver, de se disponibilizar (e investir esforços em) fóruns de discussão nesses ambientes. E se não houver um (ou mais) bom (ns) mediadore(s) (ou seja, pessoas que incentivem as interações, comentando/questionando o que foi postado) desses fóruns, não faz muito sentido adotar um ambiente virtual. Estamos acostumados a ver mais esses ambientes sendo utilizados como repositórios de conteúdo do que como espaço democrático de discussões. Sem interação, contudo, não há aprendizagem.

RA20 É UM CANAL QUE PRODUZ RETORNO, CLARO QUE SEMPRE DEVEMOS ESTAR ATENTOS AOS SITES CONSULTADOS PARA SABER SE AS INFORMAÇÕES DITAS NELE SÃO VERÍDICAS OU MERAS ILUSÕES "MENTIRAS, POIS COM O AVANÇO DA TECNOLOGIA TUDO FICA MAIS FÁCIL, COM APENAS UM CLICK SE CONSEGUE TER ACESSO A INÚMERAS INFORMAÇÕES IMPORTANTES PARA A APRENDIZAGEM DO SER HUMANO. SIM, O AMBIENTE VIRTUAL É UM CANAL DE APOIO AO ENSINO. VALE RESSALTAR QUE, ELE SERVE PARA APOIAR E, NUNCA PARA SUBSTITUIR A FUNÇÃO QUE EXERCE UM PROFESSOR(A).

Com respostas mais resumidas, como RA7, que diz ser "Totalmente favorável” ou de forma mais completa, como RA20, que admite o "retorno" que o "canal" produz, mas alerta 
para a necessidade de verificar a confiabilidade dos "sites consultados", pode-se observar que todos os 19 alunos que responderam a essa questão são favoráveis ao uso do ambiente virtual como apoio ao ensino. Há ainda aqueles que creem que a escola não pode ignorar as inovações tecnológicas, empregando-as de maneira adequada aos objetivos das práticas educacionais que promove. Nesse sentido, RA12 responde: "Acredito que seja necessário que o ensino acompanhe o desenvolvimento da tecnologia."

Os alunos pesquisados citam principalmente as questões de rapidez nos processos de comunicação e acesso a informações, como RA4, ao dizer que o ambiente virtual "auxilia na comunicação rápida e em grande escala"; RA1, ao afirmar que ele facilita "o compartilhamento de materiais didáticos"; e RA15 que faz referência à importância do "contato com a monitora do curso para esclarecimento de dúvidas bem como orientação de trabalhos", feito pelo meio virtual. RA10 comenta ainda as vantagens do ambiente virtual com relação à possibilidade de contato com o professor a qualquer tempo, ao assegurar que "se alguma dúvida surgisse não precisávamos esperar 1 semana até a próxima aula”. Tais informações coincidem com as funcionalidades de mobilidade, conectividade e assincronia, postuladas por Haythornthwaite e Andrews (2011, p. 18), e já mencionadas no Capítulo 2 desse trabalho.

Muitos deles (RA11, RA12, RA16, RA20), entretanto, fazem questão de destacar que o ambiente virtual deve funcionar apenas como apoio, sem pretensões de substituir as atividades presenciais e a 'função que exerce um professor' (RA20), considerando-o 'um auxílio’ (RA16) ‘um importante aliado’ (RA11), que deve ‘caminhar em conjunto’ (RA12) ao trabalho presencial do professor. Outros (RA19) ainda apontam que, sem interação de qualidade e uma boa mediação, não faz sentido adotar um ambiente virtual como apoio às aulas presenciais. Tais posicionamentos estão de acordo com os nossos em relação a assegurar que as atividades, realizadas tanto em ambiente presencial quanto virtual, contribuam para que haja uma interação dialógica de professor e alunos, com o objetivo de construir conhecimentos de forma conjunta.

Constata-se, portanto, que as opiniões dos alunos consultados são bastante favoráveis ao uso de ambiente virtual, embora eles enfatizem que a interação a distância não pode substituir as aulas presenciais e que a mediação professor/aluno deve ser feita de modo a incentivar a interação por meio do debate, da pesquisa e, como consequência, permitir a construção da aprendizagem. Nesse sentido, a opinião dos entrevistados está em concordância com a proposta deste estudo de acrescentar, a cada etapa das práticas presenciais de ensino de 
produção do artigo científico, a interação por meio de ambiente virtual com atividades planejadas de acordo com a funcionalidade de cada ambiente.

Na elaboração dessa proposta, destacam-se algumas atividades, por sua importância: o contato com a linguagem em funcionamento, por meio da leitura de artigos do corpus de consulta; a produção da Pauta de Revisão, elemento cuja elaboração reflete a produção dos alunos e aponta quais aspectos devem ser retomados ou aprofundados para consolidar o conhecimento necessário para passar às próximas etapas do processo; as sucessivas reescritas realizadas por parte dos alunos até chegarem à versão final de suas produções, nas quais se poderá observar a construção de conhecimento ocorrida; a participação em todo o processo e a adequação da produção final à proposta do curso como critérios de avaliação para aprovação.

Essa sucessão de atividades promovida pela movimentação entre os ambientes presenciais e virtuais instaura uma interação continuada, permitindo a constante reformulação do curso conforme os resultados obtidos após cada etapa das Sequências Didáticas, cada tarefa produzida, comentada e reescrita, cada Pauta de revisão discutida. Observando o conjunto das considerações obtidas por meio dos procedimentos metodológicos adotados, podemos dizer que essa dinâmica da interação continuada entre os ambientes de aprendizagem contribuiu de maneira significativa para a construção de conhecimento no ensino de produção de artigo científico. 
CONCLUSÃO 
Esta pesquisa buscou contribuir para os estudos sobre o desenvolvimento de competências relacionadas à produção do texto acadêmico em Língua Portuguesa no ensino superior, tendo em vista o aumento da conectividade e da colaboração promovido pela universalização das novas tecnologias de informação e comunicação.

Ao iniciarmos, por conta de nossas observações sobre o cenário universitário brasileiro e o ensino de produção de texto acadêmico, havíamos proposto questionamentos a que procuramos responder no decorrer de nossos estudos. Primeiramente, indagamos se a inserção de uma disciplina ou curso voltados ao ensino de texto acadêmico em Língua Portuguesa poderia trazer resultados significativos em termos de aprendizagem para alunos de graduação; a outra indagação referiu-se à produção de gêneros do domínio acadêmico como o artigo científico, para buscar compreender se uma proposta que combinasse atividades desenvolvidas em ambientes presenciais e virtuais poderia se justificar e por quais razões.

Os resultados obtidos pelo conjunto de procedimentos metodológicos adotados: a revisão de literatura sobre o tema, a nossa observação participante durante as duas aplicações da proposta de aprendizagem combinada de produção de texto acadêmico que elaboramos, as indagações a professores e alunos e as nossas análises permitem responder afirmativamente às duas questões que propusemos. Nessa direção, é possível afirmar que a interação continuada propiciada pela dinâmica de alternar atividades presenciais e online no ensino de produção de texto acadêmico contribui significativamente para uma aprendizagem participativa e reflexiva, que leva à construção de conhecimento no ensino superior.

Consideramos ter alcançado nosso objetivo de descrever o cenário em que hoje se insere o ensino de produção textual na universidade brasileira, em especial a pública, por meio das investigações a que procedemos e que também nos permitiram conhecer estatísticas oficiais que atestam queda no desempenho em Redação no Exame Nacional do Ensino Médio, hoje porta de acesso para o ensino superior, o que pode desfavorecer o desempenho dos futuros universitários. Além disso, tivemos conhecimento de um considerável número de iniciativas com a finalidade de suprir a demanda dos estudantes universitários por habilitarem-se a produzir os gêneros do discurso acadêmico, tanto em universidades brasileiras como em estrangeiras. Podemos também dizer que essa demanda ainda não está sendo atendida nas instituições brasileiras.

A revisão da literatura sobre ensino de produção de texto acadêmico, em especial do artigo científico, gênero que escolhemos como objeto de estudo e de ensino, permitiu inferir a crescente valorização dessa prática, visto termos encontrado muitos pesquisadores e autores 
que se dedicam ao tema, embora adotem perspectivas diferentes de nossa abordagem. Dentre os já citados no Capítulo 1, lembramos os brasileiros Severino (2007) e Motta-Roth e Hendges (2010), os americanos Swales e Feak (1994, 2004, 2012) e o grupo do qual fazem parte Castelló e Donahue (2012), pesquisadoras espanhola e americana, respectivamente, para quem os calouros enfrentam novas demandas em termos de leitura e escrita que requerem competências não necessariamente transferíveis de experiências de aprendizagem anteriores, demandas essas que podem ser atendidas pelo aprimoramento de sua prática escrita.

Podemos inferir desse conjunto de informações que a atenção de instituições e autores já foi despertada para atender às necessidades de estudantes e pesquisadores do ensino superior em relação às questões da aprendizagem de texto acadêmico, mas que ela ainda não foi implementada nas universidades brasileiras como precisará ser.

Nesse sentido, as aplicações da proposta de ensino de artigo científico em ambientes presenciais e virtuais que elaboramos permitiram observar que o processo de ensinar e produzir textos acadêmicos em língua materna de fato promove uma aprendizagem participativa e reflexiva. Consideramos, portanto, que as demandas em termos de leitura e escrita enfrentadas pelos calouros das universidades brasileiras podem ser supridas por meio de cursos em que aprendam a escrita de gêneros acadêmicos, o que pode desenvolver não só suas competências linguísticas, discursivas e textuais, como também levá-los à reflexão sobre os novos conhecimentos que a área de estudo propõe.

Além disso, entendemos que, por ocasião da graduação, quando tais conhecimentos ainda estão se consolidando, produzir gêneros do discurso acadêmico numa língua em que o aluno já é consideravelmente competente, sua língua nativa, pode auxiliar seu processo de aprendizagem. A investigação que realizamos junto a professores envolvidos com o ensino de produção de gêneros acadêmicos na universidade indica que eles concordam com esses posicionamentos, pois entendem que, além de desenvolver a escrita propriamente dita, ensinar gêneros acadêmicos também habilita à leitura crítica e à produção de diferentes gêneros, numa transferência de habilidades a outros campos de atuação.

Tendo em vista todas essas observações sobre o contexto em que se insere o ensino de produção de gêneros acadêmicos, consideramos ter atingido o objetivo de justificar nossa proposta de incluir disciplinas e cursos sobre produção de texto acadêmico em Língua Portuguesa na graduação, nas diversas áreas de conhecimento das universidades brasileiras. 
A pesquisa a partir de autores que abordam o tema da cognição contribuiu para confirmar nossa posição de que ensinar práticas linguísticas de produção textual tem várias implicações cognitivas. Silva (2007), da Linguística Cognitiva, afirma que nossa interação com o mundo é mediada pela linguagem, instrumento de construção e organização de conhecimento e, na mesma direção, Fauconnier e Turner (2002), criadores da Teoria da Mesclagem Conceptual, propõem que a capacidade humana única de fazer integrações conceituais e avançar no processo cognitivo é uma atividade mediada pelo pensamento e pela linguagem.

Nossas observações durante os cursos que ministramos e o resultado de nossas análises vão ao encontro das posições desses estudiosos da cognição, levando-nos a afirmar que, quanto mais se desenvolve a competência linguística - e a aprendizagem de produção de texto acadêmico promove o desenvolvimento de tal competência - mais conexões mentais para o avanço do processo cognitivo são estabelecidas, favorecendo tanto a construção de conhecimento linguístico como de saberes específicos, numa relação dialógica, o que corrobora hipótese que propusemos nessa direção.

Nossa outra hipótese de que combinar abordagens multimodais poderia auxiliar a construção de uma aprendizagem mais efetiva, por promover a interação em diferentes ambientes e possibilitar mais articulações cognitivas, confirmou-se na prática das aplicações de nossa proposta e também a partir do exame de autoras como Fávero, Andrade e Aquino (1998) e Kenski (2003), entre outros, que se dedicam a estudar como se dá a interação, tanto no ambiente presencial (as primeiras), como no virtual (a segunda). Contribuíram também para confirmar tal hipótese nossos estudos sobre o posicionamento de Haythornthwaite e Andrews (2011) em relação ao potencial de uso tanto das interações face a face quanto das tecnologias de comunicação mediada por computador de gerar oportunidades para comunicarse, aprender e criar entendimento e objetivos comuns.

Tais afirmativas nos levam a considerar ter atingido nosso objetivo de examinar como ocorre a interação e a construção de conhecimentos por meio da linguagem em abordagens multimodais de aprendizagem. Nossa prática de Aprendizagem combinada e o posicionamento dos estudiosos consultados reforçou nossa convicção de que os processos de ensino e aprendizagem só ocorrem de forma efetiva se estiver garantida uma interação determinada pela capacidade de ação de todos os sujeitos envolvidos, numa ação dialógica contínua em que, nesse caso, professores e alunos constroem sentidos e conhecimentos de forma conjunta. 
Embora durante nossa pesquisa tenhamos confirmado a existência de diferenças entre a interação face a face da sala de aula presencial e aquela que acontece por meio do ambiente virtual - em relação ao espaço e à sincronia ou assincronia temporal em que ocorrem -, assumimos ser mais adequado considerá-las formas complementares de interagir, em vez de opostas. O exame de pesquisadores como Paiva (2010) e Haythornthwaite e Andrews (2011), que estudam respectivamente características e funcionalidades de ambientes presenciais e virtuais de aprendizagem, também contribuiu para melhor entendermos como explorá-los de maneira a selecionar atividades pedagógicas que promovam tanto o protagonismo dos sujeitos na construção de sua aprendizagem, como a cooperação entre os participantes.

Conhecer e explorar características e funcionalidades desses dois modos de interagir sob a perspectiva de complementaridade contribuiu para conceber quais atividades pedagógicas referentes à produção do artigo científico seriam mais ajustadas a cada ambiente, presencial e virtual, e assim elaborar uma proposta de ensino que levasse a uma aprendizagem mais significativa.

Ao levar em conta os estudos que realizamos, os resultados que observamos e as declarações de alunos em relação à experiência da aplicação dessa proposta de Aprendizagem combinada de que participaram, entendemos que há, de fato, algumas práticas mais adequadas a ambientes presenciais, enquanto outras são mais ajustadas a ambientes virtuais de aprendizagem, confirmando a hipótese que levantamos nesse sentido. Consideramos também que o objetivo de estabelecer quais práticas em ambientes presenciais e virtuais podem ser mais adequadas para a aprendizagem de gêneros como o artigo científico em Língua Portuguesa tenha sido alcançado nesta pesquisa.

Em consequência dessas observações, concordamos com Garrison (2011 [2003]), quando este autor afirma que a total integração de atividades presenciais e virtuais pode ser uma resposta ao desafio de envolver alunos da educação superior num processo de aprendizagem mais participativo e, portanto, mais significativo.

Por combinar práticas pedagógicas presenciais e virtuais no ensino superior, levando em conta estudos de Haythornthwaite e Andrews (2011) que indicam as funcionalidades desses ambientes, consideramos ainda a possibilidade de a experiência que este estudo propõe na área de Blended learning (ou Aprendizagem combinada, conforme tradução que propusemos) representar uma transformação positiva na educação superior, ao maximizar a interação de alunos e professores, aumentar articulações cognitivas e ajudar a construir credibilidade para outras formas de ensino online. 
Em relação ao objetivo de observar as possíveis contribuições da teoria dos gêneros para justificar a apresentação de uma proposta de aprendizagem combinada, nossos estudos sobre a teoria dos gêneros em autores como Marcuschi (2008, 2011), Lopes-Rossi (2011) e Motta-Roth (2011), entre outros, ajudaram a comprovar a adequação de escolhermos o gênero como instrumento didático, pelas implicações discursivas, interativas e sociais que tal opção encerra. Além disso, consideramos as Sequências Didáticas de Schneuwly e Dolz (2004) maneira bastante adequada de propor aos alunos atividades desenvolvidas tanto em ambientes presenciais como virtuais, dada sua característica geral de modularidade, que admite atualizações, redirecionamentos e adaptações às características de cada grupo de alunos, respeitando sua história didática e sua heterogeneidade.

Consideramos ajustado afirmar que a escolha desses procedimentos didáticos bastante flexíveis contribuiu para que se atingisse, por meio da combinação de atividades desenvolvidas em ambientes presenciais e virtuais, uma dinâmica de interação continuada que foi decisiva para construir conhecimento no ensino de produção de artigo científico.

O conjunto de resultados que obtivemos nesta pesquisa permite-nos confirmar nossa tese de que ensinar texto acadêmico em Língua Portuguesa mediante a combinação de práticas desenvolvidas em ambientes virtuais e presenciais, uma experiência de Blended learning, pode trazer resultados de aprendizagem significativos, tanto em termos de aquisição de competências linguísticas, discursivas e textuais, como de construção de conhecimentos acadêmicos específicos de uma área, desde que essa combinação seja criteriosamente planejada em termos interativos, cognitivos e didáticos. 


\section{REFERÊNCIAS}

\section{BIBLIOGRÁFICAS}


ANDERSON, T., ROURKE, L., GARRISON, R., e ARCHER, W. Assessing teaching presence in a computer conferencing context. Journal of Asynchronous Learning Networks, vol.5(2), pp. 1-17, 2001.

AQUINO, Z. G. O. Interação e conflito no discurso oral culto (SBPC 98). Linha D'Água, Brasil, p. 11-23, jan. 2000. ISSN 2236-4242. Disponível em: http://www.revistas.usp.br/linhadagua/article/view/69174/71626. Acesso em: 13/05/2016.

Conversação e Conflito - um estudo das estratégias discursivas em interações polêmicas. 367 f. Tese (Doutorado em Linguística) Faculdade de Filosofia, Letras e Ciências Humanas da Universidade de São Paulo, São Paulo, 1997.

BACICH, L.; TANZI NETO, A.; TREVISANI, F. M. (Orgs.) Ensino Híbrido: Personalização e Tecnologia na Educação. Porto Alegre: Penso, 2015.

BAKHTIN, M. Os gêneros do discurso. In: BAKHTIN, M. Estética da criação verbal. Trad. Maria Ermantina Galvão G. Pereira. São Paulo: Martins Fontes, pp. 277-326, [1979] 1997.

BAZERMAN, C. KERANEN, N. PRUDENCIO, F. E. Facilitated Immersion at a Distance in Second Language Scientific Writing. In: CASTELLÓ, M., DONAHUE, C. (ed.) University Writing: Selves and Texts in Academic Societies (Studies in Writing, Vol. 24). Bingley, UK: Emerald Group Publishing Limited, pp. 235-248, 2012.

BRAIT, B. O processo interacional. In: PRETI, D. (org.) Análise de textos orais. São Paulo: Humanitas, v. 1, pp. 215-244, 2003.

BRETON, P. A argumentação na comunicação. Bauru/SP: Verbum/EDUSC, 1999.

CASTELlÓ, M., DONAHUE, C. (eds.) University Writing: Selves and Texts in Academic Societies (Studies in Writing, Vol. 24). Bingley, UK: Emerald Group Publishing Limited, 2012.

CASTELLÓ, M, IÑESTA, A. Texts as Artifacts-in-Activity: Developing Authorial Identity and Academic Voice in Writing Academic Research Papers. In: CASTELLÓ, M., DONAHUE, C. (eds.) University Writing: Selves and Texts in Academic Societies (Studies in Writing, Vol. 24). Bingley, UK: Emerald Group Publishing Limited, pp. 179 - 200, 2012.

CASTElló, M., MATEOS, M., CASTElls, N., IÑESTA, A., CUEVAS, I., \& SOlÉ, I. Academic Writing Practices in Spanish Universities. Electronic Journal of Research in Educational Psychology, 10 (27), pp. 569-590, 2012.

CHARAUDEAU, P. Discurso Político. Trad. Fabiana Komesu e Dílson Ferreira da Cruz. São Paulo: Contexto, 2008. (Original: CHARAUDEAU, P. Le discours politique: les masques du pouvoir. Paris: Vuibert, 2005)

COSCARELLI, C. V. Uma conversa com Gilles Fauconnier. Revista Brasileira de Linguística Aplicada, Belo Horizonte, v. 5, n. 2, pp. 291-303, 2005. Disponível em <http://www.scielo.br/scielo.php?script=sci_arttext\&pid=S1984-63982005000200012>. Acesso em 22/02/2016. 
COUTINHO, M. A.; MIRANDA, F. To describe textual genres: problems and strategies. In BAZERMAN, Ch., FIGUEIREDO, D. \& BONINI, A. (orgs). Genre in a Changing World. Perspectives on Writing. Fort Collins, Colorado: The WAC Clearinghouse and Parlor Press, pp. 35-55, 2009.

DOLZ, J.; SCHNEUWLY, B. Gêneros e progressão em expressão oral e escrita - elementos para reflexões sobre uma experiência suíça (francófona). In: SCHNEWLY, B., DOLZ, J. (e colaboradores) Gêneros Orais e Escritos na Escola. Trad. e Org. Roxane Rojo e Glaís Sales Cordeiro. Campinas: Mercado de Letras, pp. 35-60, 2004.

DOLZ, J.; GAGNON, R; DECÂNDIO, F. Produção escrita e dificuldades de aprendizagem. Adap. Joaquim Dolz e Fabrício Decândio. Trad. Fabrício Decândio e Anna Rachel Machado. Campinas: Mercado de Letras, 2010.

DOLZ, J., NOVERRAZ, M., SCHNEUWLY, B. Sequências Didáticas para o oral e a escrita: apresentação de um procedimento. In: SCHNEWLY, B., DOLZ, J. (e colaboradores) Gêneros Orais e Escritos na Escola. Trad. e Org. Roxane Rojo e Glaís Sales Cordeiro. Campinas: Mercado de Letras, pp. 81-108, 2004.

FAUCONNIER, G. Mappings. In: Mappings in Thought and Language. Cambridge: Cambridge University Press, 1997. (Disponível em: <http://dx.doi.org/10.1017/CBO9781139174220.006>, acesso em 19/02/2016)

FAUCONNIER, G.; TURNER, M. The way we think: conceptual blending and the mind's hidden complexities. New York: Basic Books, 2002.

FÁVERO, L. L. Coesão e coerência textuais. 9.ed. São Paulo: Ática, 2002.

FÁVERO, L. L.; ANDRADE, M. L. C. V. O.; AQUINO, Z. G. O. Discurso e interação - a reformulação nas entrevistas. DELTA. Documentação de Estudos em Linguística Teórica e Aplicada, SP/PUC, v. espec., pp. 91-104, 1998.

FIORIN, J. L. Astúcias da Enunciação. As categorias de pessoa, espaço e tempo. São Paulo: Ática, 1996.

GANNETT, C.; BRERETON, J.; DONAHUE, C.; DEANE, M. Encouraging and Supporting Teacher Research in the US and UK. In: Journal of Academic Writing, Vol. 1 n. 1, pp. 280296, 2011.

GARRISON, D. R. Communities of inquiry in online learning. In: ROGERS, P. L. et al (eds.), Encyclopedia of distance learning, 2nd. ed., Hershey, PA: IGI Global, pp. 352-355, 2009.

E-learning in the 21st century: A framework for research and practice. 2nd ed. Taylor \& Francis, Routledge: New York, 2011.

GARRISON, D. R.; ANDERSON, T.; ARCHER, W. Critical Inquiry in a text-based environment: Computer conferencing in higher education. The Internet and Higher Education, vol. 2 (2-3), pp. 87-105, 2000. 
GARRISON, D. R.; ANDERSON, T.; ARCHER, W. Critical thinking, cognitive presence and computer conferencing in distance education. American Journal of Distance Education, vol 15(1), pp. 7-23, 2001.

GARRISON, D. R.; VAUGHAN, N. D. Blended learning in higher education: Framework, principles, and guidelines. John Wiley \& Sons: San Francisco, 2008.

GRICE, H. P. Lógica e conversação. In: DASCAL, Marcelo. (org.) Fundamentos metodológicos da Linguística. Pragmática. V. 4. Campinas, pp. 81-103, 1982.

HAYTHORNTHWAITE, C., ANDREWS, R. E-learning Theory and Practice. London: Sage, 2011.

HORN, M. B.; STAKER, H. Blended: usando a inovação disruptiva para aprimorar a educação. Trad. Maria Cristina Gularte Monteiro; Rev. Téc.: Adolfo Tanzi Neto, Lilian Bacich. Porto Alegre: Penso, 2015. [Original: HORN, M. B.; STAKER, H. Blended: using disruptive innovation to improve schools. San Francisco: Jossey-Bass, Wiley, 2015.]

KARWOSKI, A. M.; GAYDECZKA, B.; BRITO, K. S. (Org.). Gêneros Textuais: reflexões e ensino. São Paulo: Parábola Editorial, 2011.

KENSKI, V. M. Tecnologias e ensino presencial e a distância. Campinas, SP: Papirus, 2003.

KOCH, I.G.V. A inter-ação pela linguagem. 10 ed., São Paulo: Contexto, [1992] 2007.

LAKOFF, G.; JOHNSON. M. Metaphors we live by. Chicago/London: The University of Chicago Press, 1980.

LÉVY, P. Cibercultura. São Paulo: Editora 34, 1999.

LOPES-ROSSI, M. A. G. Tendências Atuais da Pesquisa em Linguística Aplicada. In: Anais do $5^{\circ}$. Seminário de Pesquisas em Linguística Aplicada, SePLA. Taubaté: Unitau, 2009. (Disponível em <http://site.unitau.br//scripts/prppg/la/5sepla/site/comunicacoes_orais/artigomaria_aparecida.pdf>, acesso em 27/01/2016.)

Gêneros discursivos no ensino de leitura e produção de textos. In: KARWOSKI, A. M.; GAYDECZKA, B.; BRITO, K. S. (Org.). Gêneros textuais: reflexões e ensino. 4ed., São Paulo: Parábola Editorial, p. 69-82, 2011.

MACHADO, A. R.; CRISTOVÃO, V. L. L. A construção de modelos didáticos de gêneros: aportes e questionamentos para o ensino de gêneros. Linguagem em (Dis)curso,

v. $6, \quad$ n. 3, pp. 547-573, 2010. Disponível em: <http://www.portaldeperiodicos.unisul.br/index.php/Linguagem_Discurso/article/view/349/37 0>. Acesso em: 20 Abr. 2016.

MARCUSCHI, L. A. Cognição, linguagem e práticas interacionais. Rio de Janeiro: Lucerna, 2007.

Produção textual, análise de gêneros e compreensão. São Paulo: Parábola, 2008. 
Gêneros textuais: configuração dinamicidade e circulação. In: KARWOSKI, A. M.; GAYDECZKA, B.; BRITO, K. S. (Org.). Gêneros Textuais: reflexões e ensino. São Paulo: Parábola Editorial, pp. 17-31, 2011.

MARQUESI, S. C.; CABRAL, A. L. T.; ElIAS, V. M. S.; VILlELA, A. M. N. Ensino em meios digitais: uma questão de leitura e escrita. In: BENTES, A. C.; LEITE, M. Q. (Org.). Linguística de texto e análise da conversação panorama das pesquisas no Brasil. São Paulo: Cortez, pp. 354-388, 2010.

MILITÃO, J. A. Compressão e descompressão: a chave da compreensão. In: COSTA. J.C., PEREIRA, V. W., (orgs.) Linguagem e Cognição: relações interdisciplinares. Porto Alegre: EDIPUCRS, pp. 304-318, 2009.

MOITA LOPES, L. P. Oficina de Lingüística Aplicada. Campinas: Mercado de Letras, 1996.

MORAN, J. M. Educação híbrida. Um conceito-chave para a educação, hoje. In: BACICH, L.; TANZI NETO, A.; TREVISANI, F. M. (Orgs.) Ensino Híbrido: Personalização e Tecnologia na Educação. Porto Alegre: Penso, pp. 27-45, 2015.

Ensino e aprendizagem inovadores com tecnologias audiovisuais e telemáticas. In: MORAN, J. M.; MASETTO, M. T.; BEHRENS, M. A. Novas tecnologias e mediação pedagógica. 19a. ed., Campinas, SP: Papirus, 2012.

MOTA, J. C., Da Web 2.0 ao e-Learning 2.0: Aprender na Rede. Dissertação (Mestrado em Pedagogia do e-learning), Universidade Aberta, 2009.

MOTTA-ROTH, D. Questões de metodologia em análise de gêneros. In: KARWOSKI, A. M.; GAYDECZKA, B.; BRITO, K. S. (Org.). Gêneros textuais: reflexões e ensino. São Paulo: Parábola, pp. 153-173, 2011.

MOTTA-ROTH, D.; HENDGES, G. R. Produção textual na universidade. São Paulo: Parábola, 2010.

PAIVA, V. L. M. O. A sala de aula tradicional X a sala de aula virtual. In: Congresso da Associação de Professores de Língua Inglesa do Estado de Minas Gerais, 3, In: Anais ... Belo Horizonte, pp. 129-145, 2001.

PAIVA, V. M. de O. Ambientes virtuais de aprendizagem: implicações epistemológicas. Educação em Revista. [online]. vol. 26, n.3, pp. 353-370, 2010. (Disponível em < http://www.scielo.br/pdf/edur/v26n3/v26n3a18.pdf $>$, acesso em 12/10/2015.)

PAIVA, V. L. M.; RODRIGUES JR., A. Fóruns online: intertextualidade e footing na construção do conhecimento. In: MACHADO, I. L.; MELLO, R. (Orgs.). Gêneros: reflexões em análise do discurso. Belo Horizonte: Fac. de Letras/ UFMG, pp. 171- 189, 2004. (Disponível em: <http://www.veramenezes.com/forum.pdf>, acesso em: 13/10/2015.)

PASSARELLI, B. A Teoria das Inteligências Múltiplas aliada à Multimídia na Educação: Novos Rumos para o Conhecimento. In: III Simpósio Brasileiro de Geoprocessamento, 1995, 
São Paulo. Anais do III Simpósio Brasileiro de Geoprocessamento. São Paulo: Escola Politécnica da Universidade de São Paulo, v. 1. pp. 151-170, 1995.

PERELMAN, C., OLBRECHTS-TYTECA, L. Tratado da Argumentação: a Nova Retórica. $2^{a}$ ed. Trad. Maria Ermantina Galvão. São Paulo: Martins Fontes, 2005. (Original: PERELMAN, C. \& OLBRECHTS-TYTECA, L. Traité de l'Argumentation. La nouvelle rhetórique. Bruxelles: Éditions de l' Université de Bruxelles, [1958] 1983.)

PERRENOUD, P. Avaliação: da excelência à regulação das aprendizagens - entre duas lógicas. Porto Alegre: Artmed, 1999.

QUEVEDO, A., GERALDINI, A. F. S., RODRIGUES, E. A., CRESCITELli, M. F. de C. Formação em Serviço para EAD. In: XXVI CONGRESSO DA SOCIEDADE BRASILEIRA DE COMPUTAÇÃO, XII Workshop de Informática na Escola, 2006, Campo Grande. Anais eletrônicos do XXVI Congresso da Sociedade Brasileira de Computação XII Workshop de Informática na Escola, pp. 198-205, 2006. (Disponível em: http://www.brie.org/pub/index.php/wie/article/view/892/878, acesso em: 12/10/2015.)

RUSSELL, D. R.; CORTES, V. Academic and scientific texts: The same or different communities? In: CASTELLÓ, M., DONAHUE, C. (eds.) University Writing: Selves and Texts in Academic Societies (Studies in Writing, Vol. 24). Bingley, UK: Emerald Group Publishing Limited, pp. 3-17, 2012.

SABBATINI, R. M. E. Ambiente de Ensino e Aprendizagem via Internet. Instituto Edu Med. 2007. (Disponível em: 〈http://www.ead.edumed.org.br/file.php/1/PlataformaMoodle.pdf $>$, acesso em 12/10/2015.

SCHNEWLY, B. Gêneros e tipos de discurso: considerações psicológicas e ontogenéticas. In: SCHNEWLY, B., DOLZ, J. (e colaboradores) Gêneros Orais e Escritos na Escola. Trad. e Org. Roxane Rojo e Glaís Sales Cordeiro. Campinas: Mercado de Letras, pp. 19-34, 2004.

; DOLZ, J. Os gêneros escolares - das práticas de linguagem aos objetos de ensino. In: SCHNEWLY, B., DOLZ, J. (e colaboradores) Gêneros Orais e Escritos na Escola. Trad. e Org. Roxane Rojo e Glaís Sales Cordeiro. Campinas: Mercado de Letras, pp. 61-78, 2004.

SEVERINO, A. J. Metodologia do trabalho científico. $23^{\mathrm{a}}$. ed. rev. e atualizada. São Paulo: Cortez, 2007.

SILVA, A. S. A Linguística Cognitiva: uma breve introdução a um novo paradigma em Linguística. Revista Portuguesa de Humanidades, v. 1, pp. 59-101, 1997.

(ed.). Linguagem e Cognição: A Perspectiva da Linguística Cognitiva. Braga: Associação Portuguesa de Linguística, Faculdade de Filosofia da Universidade Católica Portuguesa, 2001.

Linguagem, Cultura e Cognição, ou a Linguística Cognitiva, In: SILVA, A. S., TORRES, A. \& GONÇALVES, M. (orgs.) Linguagem, Cultura e Cognição: Estudos de Linguística Cognitiva. Coimbra: Almedina, vol. 1, pp.1-18, 2004. 
Os estudos de Linguística Cognitiva do Português. Revista portuguesa de humanidades, v. 11, n. 1, pp. 51-83, 2007.

SILVA, L. A. Estruturas de participação e interação na sala de aula. In: PRETI, D. (Org.). Interação na fala e na escrita. São Paulo: Humanitas/FFLCH, v. 5, pp. 179-203, 2002.

; BARZOTTO, V. H.; RAMOS, R. R. Interação na sala de aula: possibilidades de abordagens. Entretextos (UEL), v. 1, pp. 176-201, 2010.

SILVA, P. N. D.; SANTOS, J. V. Contributos para a caracterização do género académico 'Resposta de Desenvolvimento'. III SIMELP, Simpósio Mundial de Estudos de Língua Portuguesa, pp.27-38, 2011. Disponível em: http://repositorioaberto.uab.pt/bitstream/10400.2/3578/1/Artigo\%20SIMELP\%20pp.\%2012\%2c\%2027-38.pdf>, acesso em 11/05/2016.

SWALES, J. M. Genre analysis: English in academic and research settings. Cambridge: Cambridge University Press, 1990.

; FEAK, C. B. Academic writing for graduate students. Ann Arbor, MI: University of Michigan Press, 1994.

; __ Academic writing for graduate students: Essential tasks and skills. 2nd. ed. Ann Arbor, MI: University of Michigan Press, 2004.

; ___ Academic writing for graduate students: Essential tasks and skills. 3rd ed. Ann Arbor, MI: University of Michigan Press, 2012.

TOFFLER, A. A terceira onda. Trad. João Távora. $8^{\text {a }}$. ed. Rio de Janeiro: Record, 1980. (orig. TOFFLER, A. The third wave. Bantam Books, 1980).

VAN DIJK, T. A. Macrostructures: an interdisciplinary study of global structures in discourse, interaction, and cognition. New Jersey: Lawrence Erlbaum Associates, 1980.

YAHYA, S.; AHMAD, E. A.; JALIL, K. A. The definition and characteristics of ubiquitous learning: a discussion. International Journal of Education and Development using Information and Communication Technology, v. 6, n. 1, pp. 1-11, 2010. (Disponível em: <http://search.proquest.com/openview/0f0a94e153515b97896c1c6f78bc6200/1?pqorigsite $=$ gscholar $>$, acesso em 05/11/2015.) 
ANEXOS 


\section{ANEXO A}

\section{Corpus de consulta}

Referências e links de acesso aos artigos utilizados nas aplicações da proposta que combina atividades em ambientes presenciais e virtuais para o ensino de produção de texto acadêmico.

AQUINO, Z. G. O. Interação e conflito no discurso oral culto (SBPC 98). Linha D'Água, n. spe, $\quad$ p. $11-23,2000 . \quad$ Disponível http://www.revistas.usp.br/linhadagua/article/view/69174/71626 . Acesso em 25/04/2016.

; Luques, S. U. Propaganda político-eleitoral - um discurso em busca de legitimidade. Linha D'Água, vol. 25, n. 2, pp. 131-145. Disponível em: http://www.revistas.usp.br/linhadagua/article/view/47718/51453 Acesso em 27/04/2016.

BASNIAK, M. I.; CHAVES NETO, A. Avaliação de recursos tecnológicos implantados no ensino básico através da análise de correlação canônica. Cadernos do IME-Série Estatística vol. 29, n. 2, pp. 47-62, 2010. Disponível em: http://www.epublicacoes.uerj.br/index.php/cadest/article/view/15736/1190747 Acesso em 27/04/2016. Acesso em 27/04/2016.

GOMES, R. S. Teoria semiótica e ensino de redação. Cadernos do CNLF (CiFEFil), v. X, pp. 202-216, 2007.

Disponível em: https://docs.google.com/viewer?a=v\&pid=sites\&srcid=ZGVmYXVsdGRvbWFpbnxwcm9m YWRyYXJ1Z2luYXNvdXphZ29tZXN8Z3g6NWU1MGFhZjA2Y2ZmY2UxYg . Acesso em 25/04/2016.

SOARES, F.; FROZZA, R.; PAZOS, R. E. Predição de séries financeiras utilizando wavelets e redes neurais: um modelo para os fundos de investimentos imobiliários. Cadernos do IMESérie Estatística, vol. 25, n. 2, pp. 36-53, 2008. Disponível em http://www.epublicacoes.uerj.br/index.php/cadest/article/view/15732/11903 . Acesso em 26/04/2016. 


\section{ANEXO B}

\section{Tarefa de Aluno: Resumo}

Referente à Tarefa 2 da Sequência Didática da Produção do Resumo, essa reprodução contém o texto produzido pelo aluno e os Comentários feitos pelo professor, numerados de acordo com a numeração dos segmentos de texto a que se referem. O uso apenas das iniciais do nome do aluno garantiu o sigilo quanto à autoria dessa tarefa, embora o autor tenha autorizado sua reprodução.

\section{ARGUMENTATIVIDADE E COESÃO NOS TEXTOS JORNALÍSTICOS: INSTRUMENTOS DE INFLUÊNCIA NA FORMAÇÃO DA OPINIÃO PÚBLICA (1)}

R. S. R. (2)

Resumo (3): Este artigo tem como objetivo demonstrar (4) como a argumentatividade e a coesão são fatores determinantes, em artigos jornalísticos, para a formação da opinião pública. Por meio da análise do artigo jornalístico "Possível ataque à Síria não tem base jurídica", escrito para um site de consultoria jurídica, buscar-se (5) explicitar o uso da argumentação e da coesão como instrumentos essenciais para se atingir um público determinado e para possibilitar que o texto exerça influência na formação da opinião deste público (6) Para tanto, toma-se como base... NÃO CONSIGO ENCONTRAR TEORIAS/AUTORES PARA ME BASEAR.PODERIA, POR FAVOR, ME AJUDAR? (7) (8)

Palavras-chave: Argumentatividade e coesão. artigo jornalístico. formação da opinião pública. (9)

\section{Comentários do Professor:}

(1) O título merece ser melhorado. Sugestão: Discurso jornalístico: um estudo dos mecanismos de textualidade na formação de opinião.

(2) Complete com o nome da instituição à qual você pertence: R.S.R. - FFLCH-USP.

(3) Seu resumo não atinge o número mínimo de palavras, procure ampliar.

(4) Prefira 'observar'.

(5) Digitação: 'busca-se'. 
(6) Evite repetição. Delete e insira 'dos leitores'.

(7) Sugestões de bibliografia - adicionei a primeira à lista que já havia mandado por mensagem:

CHARAUDEAU, P. Discurso das mídias. São Paulo: Contexto, 2007.

KOCH, I. G. V. Argumentação e Linguagem. São Paulo: Cortez, 2004.

PERELMAN, C., OLBRECHTS-TYTECA, L. Tratado da Argumentação: a Nova Retórica. $2^{a}$ ed. Trad. Maria Ermantina Galvão. São Paulo: Martins Fontes, 2005. (Original: PERELMAN, C. \& OLBRECHTS-TYTECA, L. Traité de l'Argumentation. La nouvelle rhetórique. Bruxelles: Éditions de l' Université de Bruxelles, (1958). 1983.)

PLANTIN, C. A Argumentação: História, teorias, perspectivas. Trad. Marcos Marcionilo. São Paulo: Parábola, 2008. (Original: PLANTIN, C. L'Argumentation. Paris: Presses Universitaires de France, 2005)

(8) Como forma de ampliar, você poderia antecipar alguns resultados de sua análise.

(9) Palavras-chave iniciadas por maiúscula. Prefira separar: Argumentatividade. Coesão. 


\section{ANEXO C}

\section{Pauta de revisão: RESUMO}

Reprodução da Pauta de Revisão sobre a Produção de Resumo, elaborada a partir de recorrências nos comentários individuais feitos nas tarefas dos alunos, sobre a atividade Tarefa 2: Produção de um Resumo para artigo científico.

Pauta de revisão: RESUMO

TAREFA 2: PRODUÇÃO de um Resumo para artigo científico: Escrever um Resumo Acadêmico, sobre tema de sua escolha, com 250 a 300 palavras e 3 a 5 palavras-chave. Enviar via ambiente virtual.

Observações após comentários individuais nas tarefas apresentadas:

a) Quanto à superestrutura:

O RESUMO deveria conter:

- Justificativa / Objetivo

- Perspectiva teórica

- Metodologia

- Resultados

- Conclusão

Obs.: Nos comentários recebidos individualmente, sua produção foi comentada quanto à Superestrutura Esquemática do Resumo (Justificativa / Objetivo; Perspectiva teórica; Metodologia; Resultados; Conclusão). Para atingir a adequação, sua produção deveria conter todos esses elementos.

b) Quanto ao tema:

- Manter o FOCO - o 'mundo' não cabe em um artigo.

c) Quanto às Fontes de pesquisa:

- Preferir consultar livros e artigos publicados para a fundamentação teórica. Procurar sites oficiais para colher dados e informações.

d) Quanto aos elementos linguísticos:

- Verificar uso de Este/esse - referência a termo posterior ou mais próximo/referência a termo anterior ou mais distante

- Optar por linguagem mais formal: “... o fato de a análise levar ao conhecimento ..." 
- Verificar concordância na Passiva sintética: “...gerando uma tendência de se realizarem pesquisas..."

- Preferir “... executaram-se os protocolos de investigação..." pois é equivalente a "foram executados os protocolos de investigação"

- Verificar uso de vírgula: “... um teste será aplicado e, após uma semana, outros examinadores..."

- Preferir o uso formal ao popular. Sugestão: "projetos mais bem dimensionados" em vez de "projetos melhor dimensionados". Indica-se como norma culta da língua: Para intensificar sentido de verbos = ele dimensionou melhor / ele conhece melhor. Para acompanhar expressões adjetivas com verbos no particípio, o 'mais' se refere a 'bem dimensionado' / 'o mais bem preparado'.

- Uso dos verbos conforme o objetivo do Resumo. Se for para um Projeto, tempos no futuro. Para um Artigo, preferir tempos no presente ou no passado. Procurar uniformizar o uso dos tempos verbais.

- Utilizar para dúvidas sobre o Novo Acordo Ortográfico o link para a página de busca no VOLP da Academia Brasileira de Letras: http://www.academia.org.br/nossa-lingua/busca-no-vocabulario?sid=23

Reprodução de alguns Comentários recorrentes:

- Observe sempre as normas definidas pelo periódico ou instituição em que seu texto será publicado. Essas normas sempre prevalecerão.

- Seu resumo está bastante adequado, pois as principais características estruturais estão presentes, como você pode observar nas marcações coloridas em seu texto reproduzido. Os recursos linguísticos utilizados estão adequados, salvo observações feitas.

- Contamos as palavras do Resumo exclusivamente pelas palavras que estão no corpo do texto. Seu resumo está um pouco acima/abaixo do limite da tarefa, mas o importante é consultar as normas da instituição de publicação.

- Em geral, a palavra Resumo antecede o texto. Em geral adota-se o alinhamento Justificado.

- Fiquei curiosa pelo título. Se possível, coloque-o ao reescrever.

- Confira as normas de publicação. Em geral, entre o título e o início do Resumo, colocam-se o nome do autor e da instituição à qual está vinculado. 


\title{
ANEXO D
}

\section{Tarefa de aluno Estatística: Introdução e Reescrita com Resumo}

Essa reprodução refere-se a um conjunto de atividades: um texto produzido por aluno, os comentários feitos pelo professor numerados de acordo com a numeração dos segmentos de texto a que se referem e a reescrita dessa Introdução a partir das observações. O uso apenas das iniciais do nome do aluno garantiu o sigilo quanto à autoria dessas atividades, embora o autor tenha autorizado sua reprodução.

\author{
Instituto de Matemática e Estatística \\ Universidade de São Paulo
}

Disciplina: FLC 0474 - "Língua Portuguesa"

Introdução de artigo científico

Objetivo

Elaboração de um texto científico sobre o impacto do consumo de álcool sobre a mortalidade no trânsito na cidade de São Paulo para constatar ou não a eficácia da Lei Seca. (1)

Fundamentos

É conhecida a associação entre o uso do álcool e mortes no trânsito. No texto a ser elaborado, (2) serão utilizados dados recentes sobre o tema, de forma a compor um panorama geral e atual.

A fonte principal de pesquisa serão artigos encontrados no website Google Acadêmico (http://scholar.google.com.br/) os quais mostrem estatísticas recentes a respeito do objetivo proposto. (3)

Este será um trabalho de análise de dados estatísticos obtidos da correlação das mortes no trânsito e consumo de álcool e a base teórica da análise dos dados será de acordo com os fundamentos teóricos que constam na obra de Morettin, P.A. E Bussab, W. O. "Estatística Básica”. 
Como exemplo de modelo inicial deste, (4) será utilizado o artigo "PERFIL DOS CONSUMIDORES DE BEBIDA ALCÓOLICA DE 18 A 30 ANOS E O IMPACTO DA LEI SECA NO COMPORTAMENTO DOS MORADORES DO RIO DE JANEIRO DE CLASSE A E B”, de Castro, G. C. et.al. Publicado no periódico Cadernos do IME - Série estatística, Universidade do Estado do Rio de Janeiro - UERJ, Rio de Janeiro - RJ - Brasil, v.30 p. 19 33, 2011.

Posteriormente serão obtidos dados a respeito da cidade de São Paulo para compor uma base de dados a ser avaliada. O período a ser analisado (5) dependerá da qualidade dos dados obtidos, porém como ponto inicial, espera-se fazer um trabalho que avalie cinco anos de mortalidade no trânsito. (6)

São Paulo, 08 de outubro de 2012

C. H. P. S.

\section{Comentários do Professor:}

(1) Ampliar o objetivo: na verdade, o objetivo é descrever o estudo, e o artigo é que tem essa função. Como justificativa da importância de seu estudo, você poderia fazer uma comparação de dados em diferentes épocas para observar se houve aumento ou diminuição de mortalidade, procurando apontar uma razão para isso. É importante definir um local, a cidade de São Paulo, por exemplo - ou algum local de onde você consiga dados com maior facilidade. A hipótese, a ser comprovada ou não, poderia ser de que, mesmo com a Lei Seca, não houve progresso, ou algo assim, que você pode conhecer ao levantar os dados.

(2) Procure não se referir ao próprio texto, mas ao estudo realizado. Fale um pouco mais sobre o contexto em que seu estudo se insere: sobre o consumo de álcool, a Lei Seca, etc.

(3) Tema de interesse e fonte de dados confiável - mas precisa especificar a base teórica, as teorias/autores que você vai usar no seu artigo - use a técnica da paráfrase ou da citação para colocar as ideias desses autores dentro de seu texto. No seu caso, mencione aquele artigo que já estudamos.

(4) Mencione só o nome do autor e a data (2011) aqui, a Referência completa vai apenas no final do artigo.

(5) Geralmente o estudo já foi feito quando se escreve o artigo para relatá-lo, prefira: “o período analisado foi ..." Pense nisso ao reescrever: há muitos verbos no futuro em sua introdução.

(6) Mencionar COMO - qual é o método / o passo a passo seguido para realizar o estudo. Prefira produzir a introdução sem os subtítulos "Objetivo", "Fundamentos" 
Reescrita Final da Introdução: (Já com Título, Resumo e Palavras-chave)

\title{
IMPACTO DA LEI SECA NA MORTALIDADE DE ACIDENTES POR TRÂNSITO EM SÃO PAULO
}

\author{
C. H. P.S.
}

Instituto de Matemática e Estatística da USP

\section{Resumo}

Estudo descritivo com o objetivo de verificar o impacto da lei 11.705/ 2008, a chamada "Lei Seca" na mortalidade por acidentes de trânsito no município de São Paulo nos anos de 2007 a 2009, (que cobrem os períodos pré e pós Lei Seca) para avaliar a eficácia imediata da lei no sentido de diminuir a mortalidade no trânsito devido ao uso do álcool por parte dos motoristas.

Palavras-chave: lei Seca, município de São Paulo, mortalidade no trânsito.

\section{Introdução}

O consumo de álcool é um hábito difundido na maioria dos países, mesmo levando a consequências como dependência, transtornos mentais, comportamento agressivo, suicídio, neoplasias, absenteísmo, dentre outros (SOIBELMAN et al., 2004, p. 539 - 540). A Organização Mundial de Saúde (OMS, 2002) aponta a combinação de direção e embriaguez como causa específica de morte entre vítimas de Acidentes de Transporte Terrestre, termo esse doravante denominado ATT.

Segundo dados da National Highway Traffic Safety Administration (NHTSA), órgão federal americano responsável pela administração da segurança no trânsito nos Estados Unidos, motoristas com concentração alcoólica de $0,2 \mathrm{~g} / \mathrm{L}$ de sangue já possuem atenção dividida com redução nas habilidades visuais e motoras e, quanto maior a concentração de álcool, maior será a probabilidade de ocorrer um ATT (NHTSA, 2008).

No Brasil, tentando diminuir o número de acidentes provocados pela mistura de álcool e direção, foi promulgada, em 19 de junho de 2008, a lei 11.705, conhecida popularmente como "Lei Seca" que alterou o Código de Trânsito Brasileiro. A partir dessa data, o motorista que fosse flagrado numa blitz policial apresentando qualquer concentração de álcool por litro 
de sangue detectável pelo 'bafômetro' estaria sujeito a multa de $\mathrm{R} \$ 957,00$, apreensão do veículo e suspensão do direito de dirigir por 12 meses. Caso a concentração de álcool no sangue fosse superior a $0,6 \mathrm{~g} / \mathrm{L}$, a infração pode ser classificada como crime com pena de reclusão (D.O.U., 2008).

Levando em conta essa relação entre o consumo de álcool e os ATT, este artigo tem por finalidade avaliar se houve impacto nos números da mortalidade no trânsito da cidade de São Paulo em decorrência da promulgação da Lei Seca. 


\section{ANEXO E}

\section{Tarefa de aluno Letras: Introdução e Reescrita}

Essa reprodução refere-se a um conjunto de atividades: um texto produzido por aluno, os comentários feitos pelo professor numerados (em algarismos romanos) de acordo com a numeração dos segmentos de texto a que se referem e a reescrita dessa Introdução a partir das observações. A análise quanto às implicações cognitivas de tal atividade foi realizada no Capítulo 4. O uso apenas das iniciais do nome do aluno garantiu o sigilo quanto à autoria dessas atividades, embora o autor tenha autorizado sua reprodução.

\section{INTRODUÇÃO}

A opinião pública é amplamente (I) influenciada pelos meios de comunicação. E, com o amplo acesso a informação, possibilitado, principalmente, pela televisão e pela internet, a quantidade de informações que pode hoje ser acessada por uma pessoa é cada vez maior. Em alguns minutos, as notícias percorrem o planeta e milhões de pessoas são influenciadas por elas.

Porém, neste contexto, é preciso refletir sobre como as inúmeras informações colocadas à disposição de cada pessoa diariamente podem, de algum modo, influenciar sua opinião. Nem toda a informação é recebida de modo eficaz (II) e aceita pelo receptor. E, neste processo, a argumentação e a referenciação exercem um papel essencial.

Quando se fala em meios de comunicação especialmente voltados para determinados setores da sociedade, a informação tem que ser trabalhada (III) de modo a facilitar sua aceitação pelo receptor. No meio jurídico, por exemplo, o modo pelo qual a argumentação de um texto é feita e a maneira pela qual os itens que tem (IV) por função estabelecer referências são utilizados tem (V) muita influência para que o receptor aceite aquilo que lhe é transmitido.

Por isso, trabalhar com textos produzidos na mídia para um público específico exige um estudo mais detido do modo de pensar e de conceber o mundo daquele grupo. E é por meio deste conhecimento que a argumentação e a referenciação podem agir de modo bastante incisivo na formação da opinião daquele público. 
Este artigo tem como objetivo observar a argumentação e a referenciação como fatores determinantes, em artigos jornalísticos, para a formação da opinião pública, especialmente no que tange a um grupo específico, qual seja o de pessoas ligadas ao mundo jurídico.

É preciso refletir sobre o modo como argumentação e referenciação (VI) são $\underline{\text { trabalhadas }}$ (VII) em um texto para que ele atinja seu objetivo. Será que basta apenas argumentar para influenciar a opinião deste público? Ou é preciso trabalhar com a argumentação e com o modo de utilização dos itens referenciais e direcioná-los ao modo de pensar e de conceber o mundo daquele público em especial?

$\underline{\text { A argumentação está intimamente ligada, na concepção contemporânea, às noções de }}$ verdade e de verossimilhança. (VIII) A noção do crível, do razoável, baseia seu estudo. A argumentação é, em suma, um modo de alcançar ou intensificar o assentimento do público, utilizando-se do discurso.

O ser humano tem o poder de impregnar na linguagem marcas de subjetividade relativas às suas crenças em geral. A maneira pela qual cada indivíduo percebe a realidade é revelada pelo uso das expressões referenciais, que se tornam ainda mais relevantes em textos formais escritos que tem (IX) por objetivo convencer alguém a compartilhar dado ponto de vista.

Por meio da análise das estratégias argumentativas utilizadas e de como ocorre a referenciação no artigo jornalístico "Possível ataque à Síria não tem base jurídica", publicado em um site de consultoria jurídica em 02/09/2013, busca-se explicitar, no presente artigo, o uso da argumentação e da referenciação como instrumentos essenciais para se atingir um público determinado e para possibilitar que o texto exerça influência na formação da opinião deste público.

Para tanto, toma-se como base as pesquisas de Koch (1996), Maingueneau (2000) e Marcuschi (1998).

OBS.: desenvolverei mais a questão da base teórica utilizada após iniciar o desenvolvimento do artigo. Como ainda não defini os autores nos quais me basearei, não consigo desenvolver muito este ponto na introdução. R. S. R. (X) 


\section{Comentários do Professor:}

(I) Seleção lexical / repetição - sugiro rever

(II) Pense um pouco nisso - o que significaria 'receber informação de modo eficaz'? - o interlocutor vai interpretar segundo seu repertório/seu mundo - ele pode até ser influenciado, convencido - por isso o uso das estratégias argumentativas e de referenciação

(III) Prefira construída/elaborada

(IV) têm

(V) têm

(VI) Substituir para evitar repetição

(VII) Rever repetição

(VIII) Procure citar o autor/ao autores que expressam esse pensamento

(IX) têm

(X) Ok. Aguardo a reescrita final.

\section{Reescrita Final da Introdução:}

\section{INTRODUÇÃO}

A opinião pública é fortemente influenciada pelos meios de comunicação. E, com o amplo acesso à informação, possibilitado, principalmente, pela televisão e pela internet, a quantidade de informações que pode hoje ser acessada por uma pessoa é cada vez maior. Em alguns minutos, as notícias percorrem o planeta e milhões de pessoas são influenciadas por elas.

Neste contexto, é preciso refletir sobre a organização do discurso e como as inúmeras informações colocadas à disposição de cada pessoa diariamente podem, de algum modo, influenciar sua opinião. Sabemos que nem toda a informação é recebida do modo como o autor pretendeu inicialmente e aceita pelo receptor como aquele espera. É, neste processo, que a argumentação e a referenciação exercem um papel essencial.

Quando se fala em meios de comunicação especialmente voltados para determinados setores da sociedade, a informação tem que ser formulada de modo a facilitar sua aceitação 
pelo receptor. No meio jurídico, por exemplo, o modo pelo qual a argumentação de um texto é feita e a maneira pela qual os itens que têm por função estabelecer referências são utilizados influenciam a aceitação pelo receptor daquilo que lhe é transmitido.

Por isso, trabalhar com textos produzidos na mídia para um público específico exige um estudo mais detido do modo de pensar e de conceber o mundo daquele grupo. E é por meio deste conhecimento que a argumentação e a referenciação podem agir de modo bastante incisivo na formação da opinião daquele público.

Este artigo tem como objetivo observar a argumentação e a referenciação como fatores determinantes, em artigos jornalísticos, para a formação da opinião pública, especialmente no que tange a um grupo específico, qual seja o de pessoas ligadas ao mundo jurídico.

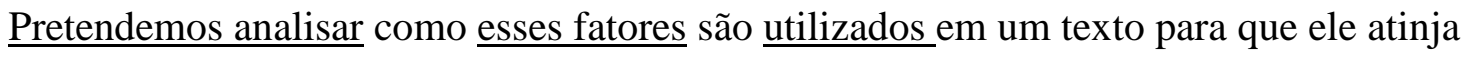
seu objetivo. Será que basta apenas argumentar para influenciar a opinião deste público? Ou é preciso trabalhar com a argumentação e com o modo de utilização dos itens referenciais e direcioná-los ao modo de pensar e de conceber o mundo daquele público em especial?

Para responder a essas questões, partimos dos seguintes conceitos (PALUMBO, 2007): 1. A argumentação está intimamente ligada, na concepção contemporânea, às noções de verdade e de verossimilhança. A noção do crível, do razoável, baseia seu estudo; 2. A argumentação é, em suma, um modo de alcançar ou intensificar o assentimento do público, utilizando-se do discurso.

O ser humano tem o poder de impregnar na linguagem marcas de subjetividade relativas às suas crenças em geral. A maneira pela qual cada indivíduo percebe a realidade é revelada pelo uso das expressões referenciais, que se tornam ainda mais relevantes em textos formais escritos que têm por objetivo convencer alguém a compartilhar dado ponto de vista (SILVA, 2011).

Por meio da análise das estratégias argumentativas utilizadas e de como ocorre a referenciação no artigo jornalístico "Possível ataque à Síria não tem base jurídica", publicado em um site de consultoria jurídica em 02/09/2013, busca-se explicitar, no presente artigo, o uso da argumentação e da referenciação como instrumentos essenciais para se atingir um público determinado e para possibilitar que o texto exerça influência na formação da opinião deste público.

Para tanto, toma-se como base as pesquisas de Marcuschi (2002), Palumbo (2007) e Charaudeau (2006). Em Marcuschi temos teoria dos gêneros como fruto da história e da 
sociedade e o estudo sobre a possibilidade de os gêneros aparecem mesclados nos textos, afastando a concepção de que estes são estáticos e imutáveis. Palumbo, por sua vez, desenvolveu uma pesquisa sobre referenciação e argumentação nas orientações argumentativas. Por fim, Charaudeau trata do discurso nas mídias e de como ocorre a recepção das informações veiculadas pelos receptores. 


\section{ANEXO F}

Modelo de email enviado a professores solicitando sua participação na pesquisa:

Prezado/a Prof./a.

Gostaria imensamente de poder contar com sua colaboração na coleta de informações para minha pesquisa de doutorado, provisoriamente intitulada "Redação acadêmica: uma proposta sociointeracionista de ensino com apoio em ambiente virtual", do Programa de Pós-Graduação de Filologia e Língua Portuguesa da Universidade de São Paulo, sob orientação da Prof. ${ }^{\text {a }}$ Dr. ${ }^{\text {a }}$ Zilda Gaspar Oliveira de Aquino.

Alguns objetivos de meu trabalho são: conhecer como se dá o ensino de produção de textos acadêmicos em algumas universidades brasileiras e se há utilização de meios digitais e ferramentas de ensino a distância como apoio a essas práticas.

A participação dá-se apenas pelo preenchimento de um questionário, cujo link tomo a liberdade de enviar-lhe abaixo.

A identidade dos informantes será mantida em anonimato e os dados gerados serão analisados no desenvolvimento da referida pesquisa.

Agradeço antecipadamente por sua atenção.

Abraços,

Profa. Ms. Solange Ugo Luques

Para ir ao questionário, clicar no link abaixo, ou copiar e colar em seu navegador:

https://docs.google.com/forms/d/1eYfupEXNOqqAkD0yTjot1ulAV5UySecuT0zrh16R oOM/viewform

P.S. Se for possível, por favor, encaminhe a seus alunos a versão 'alunos' do questionário, via link:

https://docs.google.com/forms/d/1- 


\begin{abstract}
ANEXO G
Postagem realizada no Grupo dos alunos do IME-USP da disciplina FLC0474 - Língua Portuguesa do segundo semestre de 2012, convidando-os a participar da pesquisa.
\end{abstract}

Olá, caros alunos, como estão todos?

Espero que se lembrem de mim, Profa. Solange Ugo Luques, da disciplina de Língua Portuguesa. Peço licença a vocês para usar novamente o nosso grupo do Google e solicitar a todos que respondam a uma pesquisa que estou realizando para meus estudos sobre produção de texto. A participação de vocês será muito importante para mim.

Envio abaixo o link da pesquisa, que é bastante simples e creio que não tomará muito mais de dez minutos do tempo de vocês.

Agradeço antecipadamente.

Um abraço a todos, com meu desejo de muito sucesso e um ótimo final de 2013,

Profa. Ms. Solange Ugo Luques

https://docs.google.com/forms/d/1-

qmgMwiccnntNk_cDKnN9TXBz3cRO2PpDYojqQhYXus/viewform 


\section{ANEXO H}

Respostas de Professores ao questionário que lhes foi proposto por meio do link $>$ https://docs.google.com/forms/d/1eYfupEXNOqqAkD0yTjot1uIAV5UySecuT0zrh16RoOM /viewform? $=0 \& w=1 \&$ usp $=$ mail_form_link $>$

Para garantir o anonimato dos Respondentes Professores e certificar que cada conjunto de informações tenha sido fornecido pelo mesmo indivíduo, foram atribuídas siglas numeradas RP1, RP2, RP3 - a cada um deles. As respostas às Questões 1, 2 e 3, foram omitidas por conterem identificações pessoais.

Obs.: As respostas foram transcritas exatamente como foram produzidas pelos respondentes.

\section{Questão 4: Grupo etário a que pertence}
RP1 30 a 39 anos
RP2 30 a 39 anos
RP3 60 anos ou mais
RP4 40 a 49 anos
RP5 30 a 39 anos
RP6 50 a 59 anos
RP7 20 a 29 anos
RP8 40 a 49 anos
RP9 60 anos ou mais
RP10 40 a 49 anos

\section{Questão 5: Universidade/s em que leciona}

RP1 Universidade de São Paulo - USP

Faculdades Metropolitanas Unidas - FMU

RP2 Unicamp

RP3 Universidade Federal do Rio de Janeiro

RP4 Universidade Federal do Rio de Janeiro

RP5 UFRJ

Universidade Candido Mendes

RP6 Universidade Federal de Uberlândia 
RP7 UNIESP

RP8 UERJ

RP9 UERJ - INSTITUTO DE LETRAS

RP10 Pontifícia Universidade Católica do Paraná

\section{Questão 6: Nome do/s curso/s em que leciona}

RP1 USP: Letras e Estatística

FMU: Secretariado Executivo Trilíngue, Letras.

RP2 Curso de extensão de redação científica

RP3 Graduação em Letras e Pós -Graduação "stricto sensu"-Mestrado e Doutorado

RP4 Letras

RP5 Letras, Licenciatura em Química e Licenciatura em Física

RP6 Licenciatura Plena em Letras

RP7 Letras

RP8 Letras

RP9 Graduação em Letras

Mestrado e Doutorado em Língua Portuguesa

RP10 Letras e Engenharia da Computação.

\section{Questão 7: Nome da/s disciplina/s que ministra}

RP1 USP: Introdução aos Estudos de Língua Portuguesa II (Letras), Língua Portuguesa (IME)

FMU: Técnicas de Redação Empresarial e Trabalho de Conclusão de Curso (Secretariado), Semântica, Gramática Normativa (Letras)

RP2 Curso de extensão de redação científica

RP3 Semântica e Léxico, Texto e ensino

RP4 Ensino de língua portuguesa, Desenvolvimento metalinguístico

RP5 Leitura e Produção Textual em Língua Portuguesa, Português Instrumental I

RP6 Aprendizagem Crítico-Reflexiva, Fundamentos Linguísticos, Metodologia de Ensino de Línguas, Metodologia de Pesquisa em Letras

RP7 Língua Portuguesa, Linguística

RP8 Linguística I, II e IV. 
RP9 Graduação: Fonologia, Dialectologia, Semântica, Prática de Produção Textual no Ensino Fundamental e Médio, Oficina de Preparação de Originais

Pós-Graduação Estrito Sensu: Semiótica, Semiótica aplicada, Fonologia, Lexicologia, Filologia, Semântica, Metodologia de Pesquisa. Leitura e Produção Textual

RP10 Letras: Semântica e Análise do Discurso.

Engenharia da Computação: Leitura e Produção de Textos Acadêmicos.

\section{Questão 8: Tempo de experiência como professor universitário}

$\begin{array}{ll}\text { RP1 } & 4 \text { a } 6 \text { anos } \\ \text { RP2 } & 1 \text { a } 3 \text { anos } \\ \text { RP3 } & \text { Mais de } 20 \text { anos } \\ \text { RP4 } & \text { Mais de } 20 \text { anos } \\ \text { RP5 } & 1 \text { a } 3 \text { anos } \\ \text { RP6 } & \text { Mais de } 20 \text { anos } \\ \text { RP7 } & 1 \text { a } 3 \text { anos } \\ \text { RP8 } & 11 \text { a } 15 \text { anos } \\ \text { RP9 } & \text { Mais de } 20 \text { anos } \\ \text { RP10 } & 11 \text { a } 15 \text { anos }\end{array}$

\section{Questão 9: Suas aulas são:}

RP1 Presenciais

RP2 Presenciais, mas utiliza meios digitais para se comunicar com os alunos fora do horário de aula

RP3 Presenciais

RP4 Presenciais, mas utiliza meios digitais para se comunicar com os alunos fora do horário de aula

RP5 Presenciais

RP6 Presenciais, mas utiliza meios digitais para se comunicar com os alunos fora do horário de aula

RP7 Presenciais, mas utiliza meios digitais para se comunicar com os alunos fora do horário de aula

RP8 Presenciais

RP9 Presenciais, mas utiliza meios digitais para se comunicar com os alunos fora do horário de aula 
RP10 Presenciais, mas utiliza meios digitais para se comunicar com os alunos fora do horário de aula

Questão 10: Que metodologia você utiliza para ministrar a/s disciplina/s que leciona? É possível escolher várias alternativas.

RP1 Aulas expositivas, Leitura de textos teóricos, Seminários em grupo, Seminários individuais, Produção de textos, Reescrita de textos após revisão, Análise de textos

RP2 Aulas expositivas, Produção de textos, Reescrita de textos após revisão, exercício de paráfrase

RP3 Aulas expositivas, Questionários, Leitura de textos teóricos, Seminários em grupo, Seminários individuais, Produção de textos, Reescrita de textos após revisão

RP4 Aulas expositivas, Seminários em grupo, Seminários individuais, Produção de textos, atividades orais - debates

RP5 Aulas expositivas, Questionários, Leitura de textos teóricos, Produção de textos, Reescrita de textos após revisão, Trabalho com músicas, filmes e quadros

RP6 Aulas expositivas, Questionários, Leitura de textos teóricos, Seminários em grupo, Seminários individuais, Produção de textos, Reescrita de textos após revisão

RP7 Aulas expositivas, Questionários, Leitura de textos teóricos, Seminários em grupo, Seminários individuais, Produção de textos, Reescrita de textos após revisão, Produção de materiais didáticos

RP8 Aulas lúdicas

RP9 Aulas expositivas, Leitura de textos teóricos, Seminários em grupo, Produção de textos, Reescrita de textos após revisão

RP10 Aulas expositivas, Leitura de textos teóricos, Seminários em grupo, Produção de textos, Reescrita de textos após revisão, Análise linguística e revisão de texto.

Questão 11: O ensino de produção de texto acadêmico ou de artigo científico é um dos objetivos da disciplina que você leciona?

$\begin{array}{ll}\text { RP1 } & \text { Sim } \\ \text { RP2 } & \text { Sim } \\ \text { RP3 } & \text { Sim } \\ \text { RP4 } & \text { Sim } \\ \text { RP5 } & \text { Sim } \\ \text { RP6 } & \text { Sim } \\ \text { RP7 } & \text { Não } \\ \text { RP8 } & \text { Não } \\ \text { RP9 } & \text { Sim }\end{array}$


RP10 Sim

Questão 12: Em caso de resposta positiva à pergunta anterior, há quanto tempo você já leciona disciplina/s que tem/têm esse objetivo?

RP1 Há 4 anos

RP2 3 anos

RP3 Acredito que sempre, pois na Pós, nossos cursos têm por objetivo sempre preparar o aluno para um trabalho teórico ou de aplicação acadêmico, com vista a ser publicado ou apresentado em Congressos nacionais ou internacionais. Os trabalhos têm o formato de artigo, muitas vezes......Também na Graduação já lecionei vários anos em uma Disciplina - Produção de Texto, cuja função é ensinar a produzir texto acadêmico, mesmo a alunos iniciantes

$\begin{array}{ll}\text { RP4 } & \text { dez anos } \\ \text { RP5 } & 1 \text { ano } \\ \text { RP6 } & \text { desde } 2011 \\ \text { RP7 } & - \\ \text { RP8 } & - \\ \text { RP9 } & 1994 \\ \text { RP10 } & 10 \text { anos }\end{array}$

Questão 13: Se você respondeu que ensinar a produzir texto acadêmico é um dos objetivos de sua disciplina, você considera que essa prática promove a aprendizagem em geral? Por quê?

RP1 Sim, em razão de tanto colaborar para o ensino de língua quanto promover discussão e reflexão sobre determinados temas, específicos da área do curso.

RP2 Sim, porque, com as técnicas e correções dos textos dos alunos, consigo ver melhorias consideráveis, em especial em relação à seleção de informação e coesão referencial.

RP3 Sim, leva o aluno a ter uma atitude crítica perante o conhecimento. O agravante é que o aluno não vem preparado do Ensino Médio para esse gênero de texto, que exige compreensão de textos teóricos, da nomenclatura específica e sua aplicação a um "objeto de estudo", além disso, há a preparação para uma leitura crítica dos arcabouços teóricos.

RP4 Pela minha opção em relacionar a produção de linguagem oral e escrita ao desenvolvimento metalinguístico da pessoa, o que lhe proporciona, através do conhecimento sobre a linguagem como estrutura e como meio semiótico, uma maior autonomia nas diferentes práticas de letramento em que se engaja.

RP5 Sim, pois, de certa forma, auxilia os alunos, especialmente os calouros, a se planejarem ao lerem textos mais longos e exigidos durante o curso. Com fichamentos, resumos e resenhas, muitas vezes, não e necessário voltar ao teto original para estudar para a prova. 
RP6 Sim. Aprender a escrever textos acadêmicos é entrar em contato com os princípios básicos da escrita em geral.

RP7

RP8

RP9 A produção do texto acadêmico, além do domínio da norma padrão da língua portuguesa, implica pesquisa prévia e reflexão. Assim sendo, a preparação para tal produção serve de base para que o aluno aprenda estudar.

RP10 Sim. As atividades de leitura e produção de textos acadêmicos, quando acompanhadas da análise linguística, da revisão e da reescrita de texto, promovem a aprendizagem, ou seja, o letramento acadêmico. Por meio desses procedimentos metodológicos, os alunos observam e compreendem as características textuais e discursivas dos gêneros que circulam no meio acadêmico, bem como percebem que esses elementos são fundamentais na construção do sentido dos diversos gêneros. Portanto, os alunos precisam apreender esses recursos para ler e produzir, com competência, os diversos gêneros, presentes no universo acadêmico, bem como transferir esses conhecimentos para prática profissional.

Questão 14: Você utiliza meios digitais para se comunicar com seus alunos como forma complementar de apoio às aulas presenciais?

$\begin{array}{ll}\text { RP1 } & \text { Sim } \\ \text { RP2 } & \text { Sim } \\ \text { RP3 } & \text { Sim } \\ \text { RP4 } & \text { Sim } \\ \text { RP5 } & \text { Sim } \\ \text { RP6 } & \text { Sim } \\ \text { RP7 } & \text { Sim } \\ \text { RP8 } & \text { Sim } \\ \text { RP9 } & \text { Sim } \\ \text { RP10 } & \text { Sim }\end{array}$

Questão 15: Em caso de resposta positiva à questão anterior, como se dá essa comunicação?

RP1 Apenas e-mail

RP2 Utilização de ambientes educacionais do tipo plataforma Moodle

RP3 Utilização de ambientes educacionais do tipo plataforma Moodle

RP4 Formação de um grupo de e-mails e utilização do correio eletrônico convencional

RP5 Abertura de uma página no Facebook 
RP6 Formação de um grupo de e-mails e utilização do correio eletrônico convencional

RP7 Utilizo as três primeiras simultaneamente

RP8 Abertura de uma página no Facebook

RP9 Criação de um grupo no Google

RP10 Formação de um grupo de e-mails e utilização do correio eletrônico convencional

\title{
Questão 16: Quem cuida desse grupo? Você mesmo ou um monitor?
}

\author{
RP1 - \\ RP2 - \\ RP3 eu mesma, mas conto com aluno bolsista \\ RP4 eu mesma \\ RP5 Eu mesma. \\ RP6 Eu mesmo \\ RP7 Depende \\ RP8 Eu e um monitor \\ RP9 Eu mesma. \\ RP10 Eu cuido do grupo
}

\section{Questão 17: Que atividades você realiza por meio dessa comunicação virtual? Indique, por favor, todas as alternativas que se aplicam.}

RP1 Envia avisos sobre calendário e programa da disciplina, Recebe e manda mensagens a alunos individualmente sobre temas da disciplina, Recebe e manda mensagens a alunos individualmente sobre temas que não se referem à disciplina, Recebe tarefas, Orienta a produção de tarefas, Revisa e comenta tarefas

RP2 Posta textos teóricos, Envia avisos sobre calendário e programa da disciplina, Recebe e manda mensagens a alunos individualmente sobre temas da disciplina, Recebe tarefas, Orienta a produção de tarefas, Revisa e comenta tarefas, Propõe e gerencia fóruns de discussão

RP3 Posta textos teóricos, Envia avisos sobre calendário e programa da disciplina, Recebe e manda mensagens a alunos individualmente sobre temas da disciplina, Propõe tarefas, Recebe tarefas, Orienta a produção de tarefas, Propõe e gerencia fóruns de discussão

RP4 Posta textos teóricos, Envia avisos sobre calendário e programa da disciplina, Recebe e manda mensagens a alunos individualmente sobre temas da disciplina, Recebe e manda mensagens a alunos individualmente sobre temas que não se referem à disciplina, Propõe tarefas, Recebe tarefas, Orienta a produção de tarefas, Revisa e comenta tarefas 
RP5 Posta textos teóricos, Envia avisos sobre calendário e programa da disciplina, Recebe e manda mensagens a alunos individualmente sobre temas da disciplina, Orienta a produção de tarefas

RP6 Posta textos teóricos, Envia avisos sobre calendário e programa da disciplina, Recebe e manda mensagens a alunos individualmente sobre temas da disciplina, Recebe e manda mensagens a alunos individualmente sobre temas que não se referem à disciplina, Propõe tarefas, Recebe tarefas, Orienta a produção de tarefas, Revisa e comenta tarefas, Realiza questionários, Propõe e gerencia fóruns de discussão

RP7 Posta textos teóricos, Envia avisos sobre calendário e programa da disciplina, Recebe tarefas, Orienta a produção de tarefas, Revisa e comenta tarefas, Realiza questionários

RP8 Posta textos teóricos, Envia avisos sobre calendário e programa da disciplina, Recebe e manda mensagens a alunos individualmente sobre temas da disciplina, Recebe e manda mensagens a alunos individualmente sobre temas que não se referem à disciplina, Propõe tarefas, Recebe tarefas, Orienta a produção de tarefas, Revisa e comenta tarefas

RP9 Posta textos teóricos, Envia avisos sobre calendário e programa da disciplina, Recebe e manda mensagens a alunos individualmente sobre temas da disciplina, Recebe e manda mensagens a alunos individualmente sobre temas que não se referem à disciplina, Propõe tarefas, Recebe tarefas, Orienta a produção de tarefas, Revisa e comenta tarefas, Realiza questionários

RP10 Posta textos teóricos, Envia avisos sobre calendário e programa da disciplina, Recebe e manda mensagens a alunos individualmente sobre temas da disciplina, Propõe tarefas, Recebe tarefas, Orienta a produção de tarefas, Realiza questionários

\section{Questão 18: Você enfrenta algum tipo de problema por conta da utilização desses ambientes virtuais? Em caso positivo, quais?}

RP1 Não, pois apenas utilizo o e-mail como ferramenta de apoio às aulas presenciais.

RP2 às vezes, há alunos que têm dificuldades de acessar e encontrar os materiais, mas, em geral, o Teleduc funciona muito bem como plataforma de apoio. Já usei o grupo do Google em outras turmas e não funcionava tão bem para envio de materiais e correção de textos.

RP3 Não

RP4 Não.

RP5 Nenhum problema, pois os alunos que não têm facebook - poucos, por sinal - são informados pelos demais colegas.

RP6 Alunos que ainda possuem resistência ao contato digital.

RP7 Não. Os alunos preferem.

RP8 1-) Nem todos acessam. 2-) Alguns reclamam por ter tarefas virtuais.

RP9 Sim. Ainda que o acesso ao meio digital hoje seja possível por diversos tipos de equipamentos, há alguns alunos que não apresentam domínio satisfatório da comunicação pela web. O manuseio de PC, notebook, netbook, tabletes ainda não atinge ao coletivo dos alunos. A diligência no uso de e-mails ainda deixa muito a desejar. Todavia, venho 
incrementando semestre a semestre a exploração dos recursos digitais na minha prática pedagógica cotidiana."

RP10 Apesar das inúmeras vantagens proporcionadas pelo Eureka (Sistema institucional da PUCPR), as atividades, organizadas pelo professor, precisam ser orientadas de forma detalhada a fim de que os alunos compreendam o que precisa ser feito e como deve ser feito. Por exemplo, caso a alunos não postem os trabalhos no local solicitado, o professor levará um tempo significativo para localizar esses trabalhos. Todos os roteiros que orientam a execução de atividades, realizadas a distância, precisam ser objetivos e claros e isso requer tempo e dedicação. O professor precisa reavaliar as orientações a fim de observar se elas estão adequadas e se atendem ao propósito comunicativo. Enfim, é preciso dispor de muito tempo para preparar as atividades e, muitas vezes, o professor não é remunerado de forma adequada.

Questão 19: E no que diz respeito aos alunos, como se dá o envolvimento deles com o ambiente virtual? Indique, por favor, todas as alternativas que se aplicam.

RP1 Não reclamam, Participam ativamente

RP2 Aceitam prontamente, Participam pouco

RP3 Aceitam prontamente

RP4 Aceitam prontamente, Participam ativamente, Aprendem rapidamente a acessar e utilizar as ferramentas digitais

RP5 Aceitam prontamente, Participam ativamente, Aprendem rapidamente a acessar e utilizar as ferramentas digitais

RP6 Aceitam prontamente, Reclamam, Participam pouco, Têm dificuldades em acessar os meios digitais

RP7 Aceitam prontamente, Participam ativamente, Aprendem rapidamente a acessar e utilizar as ferramentas digitais

RP8 Aceitam prontamente, Participam ativamente

RP9 Aceitam prontamente, Reclamam, Participam pouco, Têm dificuldades em acessar os meios digitais

RP10 Aceitam prontamente, Não reclamam, Participam ativamente, Aprendem rapidamente a acessar e utilizar as ferramentas digitais, Alguns têm dificuldade em acessar os meios digitais.

Questão 20: Que importância você atribui ao uso desse 'canal virtual' como forma de apoio ao ensino de produção de texto acadêmico? Por quê?

RP1 Quanto ao e-mail, ele torna mais rápido o diálogo entre professor e aluno, mas é uma ferramenta limitada. Não consigo resolver, via e-mail, todos os assuntos que são enviados. Muitos alunos procuram-me pessoalmente, principalmente, em casos de correção de trabalho.

RP2 Como não usamos material apostilado nem livro (apenas indicações de leitura extra), o canal virtual é a forma como distribuo os materiais didáticos do curso. Além disso, ele facilita 
o controle de postagem das tarefas dos alunos e a correção que faço dos textos. Se contasse apenas com envio e resposta por e-mail seria muito complicado para fazer o gerenciamento.

RP3 Estamos na era virtual e o aproveitamento desses recursos é cada vez mais uma realidade. Acho que tanto os professores quanto os alunos se beneficiam, quando há planejamento.

RP4 Oportunidade de manter contato constante, resolvendo questões gerais do curso e específicas de cada aluno sem a necessidade presencial, e de monitorar o interesse dos alunos nos aspectos da disciplina.

RP5 Como encontro meu alunos, em geral, uma ou duas vezes por semana, e, quase sempre, utilizo material de apoio nas aulas, preciso que os eles levem os textos impressos os salvos em seus tablets e demais aparelhos. Além disso, posto material complementar e tiro dúvidas on line

RP6 Essencial. Uma logística pedagógica a meu ver indispensável. Prático, rápido, objetivo, facilita a relação tempos e movimentos, ágil, funcional, de grande alcance, retorno rápido, facilita o processo acadêmico e pedagógico de funcionamento da disciplina.

RP7 Fundamental, pois as práticas digitais constituem a produção acadêmica.

RP8 Não é o objetivo desse canal, portanto não vejo relação.

RP9 Para mim é fundamental, sobretudo porque desenvolvi uma metodologia de correção de textos com instruções gramaticais, semânticas, estilísticas etc. para reescritura. Essa prática é desenvolvida com ao auxílio dos e-mails e anexação de arquivos, além da exploração de recursos digitais de editor de textos.

RP10 Embora as ferramentas, presentes no "canal virtual", sejam importantes, elas só serão consideradas recursos pedagógicos fundamentais quando o professor e aluno conseguiram utilizá-las de modo produtivo. Ou seja, quando os recursos disponíveis no "canal virtual" (correios, fórum, chat, blog e outros) favorecerem as competências de leitoras e escriturais. Não considero que o canal virtual, por ele mesmo, apoie o ensino da produção de texto acadêmico. O professor deve utilizar os recursos disponíveis, nesse "canal virtual", para delinear metodologias que promovam as competências de leitura e escrita. 


\section{ANEXO I}

Respostas de alunos ao questionário que lhes foi proposto por meio do link: https://docs.google.com/forms/d/1qmgMwiccnntNk cDKnN9TXBz3cRO2PpDYojqQhYXus/viewf orm?c $=0 \& w=1 \& u s p=$ mail form link

Para garantir o anonimato dos Alunos Respondentes e certificar que cada conjunto de informações tenha sido fornecido pelo mesmo indivíduo, foram atribuídas siglas numeradas RA1, RA2, RA3 - a cada um deles. As respostas às Questões 1, 2 e 3, foram omitidas por conterem identificações pessoais.

Obs.: As respostas foram transcritas exatamente como foram produzidas pelos respondentes.

\section{Questão 4: Grupo etário a que pertence}

RA1 21 a 25 anos

RA2 30 a 39 anos

RA3 17 a 20 anos

RA4 21 a 25 anos

RA5 17 a 20 anos

RA6 21 a 25 anos

RA7 30 a 39 anos

RA8 21 a 25 anos

RA9 21 a 25 anos

RA10 17 a 20 anos

RA11 21 a 25 anos

RA12 21 a 25 anos

RA13 30 a 39 anos

RA14 26 a 29 anos

RA15 21 a 25 anos

RA16 21 a 25 anos

RA17 30 a 39 anos

RA18 17 a 20 anos

RA19 30 a 39 anos

RA20 21 a 25 anos 
Questão 5: Universidade em que estuda

RA1 Usp

RA2 Usp

RA3 Universidade de São Paulo

RA4 USP

RA5 USP

RA6 USP

RA7 USP

RA8 Universidade de São Paulo

RA9 Universidade de São Paulo

RA10 USP

RA11 Universidade de São Paulo

RA12 Universidade de São Paulo

RA13 USP

RA14 Usp

RA15 Universidade de São Paulo

RA16 universidade federal de uberlandia

RA17 UFU

RA18 UERJ

RA19 UNICAMP

RA20 UERJ

Questão 6: Nome do curso que faz

RA1 Bacharelado em Estatística

RA2 Estatística

RA3 bacharelado em estatística

RA4 Estatística

RA5 Estatística

RA6 Bacharelado em Estatística

RA7 Bacharelado em Estatística

RA8 Estatística

RA9 Bacharelado Estatística 
RA10 Bacharelado em Estatística

RA11 Bacharelado em Estatística

RA12 Letras

RA13 Letras

RA14 Letras

RA15 Letras

RA16 letras

RA17 LETRAS INGLES

RA18 Letras

RA19 Linguística Aplicada

RA20 LETRAS/ POTUGUÊS-ESPANHOL

Questão 7: Ano de ingresso nesse curso

RA1 2012

RA2 2012

RA3 2012

RA4 2011

RA5 2011

RA6 2012

RA7 2012

RA8 2012

RA9 2010

RA10 2012

RA11 2009

RA12 2011

RA13 2009

RA14 2009

RA15 2012

RA16 2012

RA17 2012

RA18 2012

RA19 2008 
RA20 2012

Questão 8: Seu curso é

RA1 Totalmente presencial

RA2 Totalmente presencial

RA3 Totalmente presencial

RA4 Totalmente presencial

RA5 Totalmente presencial

RA6 Totalmente presencial

RA7 Totalmente presencial

RA8 Totalmente presencial

RA9 Totalmente presencial

RA10 Totalmente presencial

RA11 Totalmente presencial

RA12 Totalmente presencial

RA13 Totalmente presencial

RA14 Totalmente presencial

RA15 Totalmente presencial

RA16 Totalmente presencial

RA17 Totalmente presencial

RA18 Totalmente presencial

RA19 Totalmente presencial

RA20 Totalmente presencial

Questão 9: No curso que frequenta no momento, você já fez ou está fazendo disciplina que envolva o ensino de produção de texto?

RA1 Sim

RA2 Sim

RA3 Não

RA4 Sim

RA5 Sim

RA6 Sim 
RA7 Sim

RA8 Sim

RA9 Sim

RA10 Sim

RA11 Sim

RA12 Sim

RA13 Sim

RA14 Sim

RA15 Sim

RA16 Sim

RA17 Sim

RA18 Sim

RA19 Sim

RA20 Sim

Questão 10: Em caso de resposta positiva à pergunta anterior, responda às questões que seguem. Qual é o nome da disciplina que você cursa/cursou?

RA1 Língua Portuguesa

RA2 Língua Portuguesa

RA3 -

RA4 Língua Portuguesa

RA5 Língua Portuguesa

RA6 Língua Portuguesa

RA7 Língua Portuguesa

RA8 Língua Portuguesa

RA9 Língua portuguesa

RA10 Língua Portuguesa I

RA11 Língua Portuguesa

RA12 Leitura e Produção de Textos II

RA13 Leitura e Produção de Texto

RA14 Produções de texto 2

RA15 Leitura e produção de textos II 
RA16 metodologia de pesquisa em letras

\section{RA17 METODOLOGIA}

RA18 Prática de Produção Textual I e II

RA19 Produção Escrita em Língua Materna

RA20 PRÁTICA DE PRODUÇÃO TEXTUAL I E II

\section{Questão 11: Enumere, resumidamente, as atividades que você desenvolve/desenvolveu nessa disciplina.}

RA1 Leitura e produção de textos acadêmicos.

RA2 Leitura e interpretação de textos, Produção de artigo científico

RA3 -

RA4 A principal meta consistiu em escrever um artigo científico. Ao longo do curso foram realizadas atividades com a finalidade de conhecer técnicas para a redação de um artigo, como escrever resumos, resenhas e foram analisados textos científicos para se familiarizar com a linguagem e a estrutura.

RA5 Em suma, o objetivo da disciplina era desenvolver nos alunos a capacidade de elaboração de textos científicos.

RA6 Desenvolvimento de Relatório Estatístico com base num projeto do CEA (Centro de Estatística Aplicada), Desenvolvimento de um pôster baseado no mesmo projeto.

RA7 Leitura de textos e atividades voltadas à produção de artigos científicos.

RA8 Relatórios, Produção de Textos, Resumos, Artigos

RA9 Aprendi como fazer um relatório científico

RA10 Realização de resumo e introdução para um trabalho acadêmico, realização de apresentação (estilo powerpoint) e de um pôster ambos acadêmicos também.

RA11 Análise de artigos científicos provenientes da área de Ciência da Computação, Produção de artigo científico em tema da minha área (Estatística), Noções acerca da produção de textos: coesão e coerência, paráfrase e citação, competências linguísticas, entre outras.

RA12 Estudamos linguística textual, Estudamos estratégias para a construção de um texto, Estudamos as normas da ABNT, Realizamo a produção de um artigo acadêmico com acompanhamento contínuo.

RA13 Quanto à forma: desenvolver os textos a partir das normas da ABNT para trabalhos científicos, Quanto ao conteúdo: analisar questões de coesão e coerência, intertextualidade e como argumentar em artigo científico.

RA14 Escrevemos um artigo cientifico

RA15 desenvolvimento de técnicas para produção de artigo científico, atividades via moodle (à distância), orientação para trabalho dada pela professora e pela monitora do curso 
RA16 1 - desenvolvimento de estruturação modelo de trabalho de Iniciação Científica, 2 produção textual dentro do formato proposto, 3 - normas ABNT, 4 - considerações teóricas acerca da produção do projeto, 5 - seleção de arcabouço teórico

RA17 PESQUISA, LEITURA, MONTAGEM DE TEXTO.

RA18 Produção de alguns gêneros textuais.

RA19 Discussões teóricas, Provas

RA20 -RESENHA CRÍTICA, -REESCRITURA DE CONTO, -PRODUÇÃO E PARÁGRAFO PADRÃO, -PRODUÇÃO DE UMA NOTÍCIA DE JORNAL, -ARTIGO SOBRE UM TEXTO, -CRÔNICA

Questão 12: O ensino de produção de texto acadêmico (ou artigo científico) fez/faz parte das atividades desenvolvidas nessa disciplina?

RA1 Sim

RA2 Sim

RA3 -

RA4 Sim

RA5 Sim

RA6 Não

RA7 Sim

RA8 Sim

RA9 Sim

RA10 Sim

RA11 Sim

RA12 Sim

RA13 Sim

RA14 Sim

RA15 Sim

RA16 Sim

RA17 Sim

RA18 Não

RA19 Não

RA20 Sim 
Questão 13: Se você respondeu "Sim", você crê que aprender a produzir textos acadêmicos possa contribuir na promoção da aprendizagem de outras disciplinas? Por quê?

RA1 Outras disciplinas exigem a produção de textos acadêmicos, sendo necessária sua aprendizagem.

RA2 Sim, porque facilita a leitura e compreensão dos textos científicos das outras disciplinas - mesmo sendo de exatas, a estrutura permanece a mesma. Auxilia também na estruturação de um pensamento lógico, baseado em argumentos da literatura e não apenas em conjecturas.

RA3 -

RA4 Sim porque auxilia no desenvolvimento de atividades em que a produção de textos acadêmicos é necessária para explicar determinado estudo.

RA5 Com certeza. Em todos os níveis de ensino, faz-se necessária a produção de textos científicos, com boa base teórica e argumentação.

RA6 -

RA7 Não. O foco desta graduação é totalmente matemático.

RA8 Porque proporciona uma série de ferramentas uteis para ser aplicada a outras áreas do conhecimento!

RA9 Sim, pois ajuda bastante no desenvolvimento da área acadêmica do curso.

RA10 Sim, pois, por exemplo, no curso de estatística mesmo, temos uma matéria no quarto ano que temos que elaborar um texto desse tipo, então é de grande ajuda aprender o quanto antes. Essa atividade é ainda mais importante para aqueles que desejam seguir carreira no meio acadêmico.

RA11 Julgo que não há contribuição na aprendizagem das disciplinas em si, no caso do meu curso; porém, a experiência técnica adquirida foi (e será) valiosa para a vida pessoal e profissional.

RA12 Acredito que o aprendizado da produção de textos acadêmicos contribui com outras disciplinas. Primeiramente, porque existe uma norma para construir trabalhos acadêmicos que deve ser seguida na maioria das matérias, logo estaríamos aptos para a produção desses trabalho. Em segundo lugar, aprender a produzir um texto acadêmico ajuda no desenvolvimento e na elaboração das ideias em torno de uma análise.

RA13 Sim, porque treinar produção de texto acadêmico colabora inclusive a organizar o conteúdo oriundo de qualquer outra disciplina.

RA14 Sim, pq nos auxilia a saber escrever melhor os trabalhos de outras disciplinas.

RA15 Sim, a partir disso é possível aprimorar a escrita, adequando trabalhos e outras atividades ao meio acadêmico.

RA16 Com certeza. A confiança que a produção de um texto acadêmico dá é muito positivo. Além de melhorar a escrita, a produção, a seleção de corpus para análise, arcabouço teórico. 
RA17 SEM DUVIDAS. FOI DE FUNDAMENTAL IMPORTANCIA. ACREDITO AINDA QUE ESTA MATERIA DEVERIA ESTAR NO SEGUNDO SEMESTRE E NAO NO TERCEIRO.

RA18 -

RA19 -

RA20 SIM. DEVIDO AO FATO DO INDIVÍDUO SE TORNAR MAIS CRÍTICOS E TER HABILIDADE PARA DISCUTIR E PRODUZIR DIFERENTES TIPOS DE TEXTOS. ISSO DE UM MODO GERAL CONTRIBUI PARA A FLUIDEZ DA APRENDIZAGEM DE OUTRAS DISCIPLINAS.

Questão 14: O professor ou monitor responsável pela disciplina utilizou meios digitais para se comunicar com os alunos fora do horário de aula presencial?

RA1 Sim

RA2 Sim

RA3 -

RA4 Sim

RA5 Sim

RA6 Sim

RA7 Sim

RA8 Sim

RA9 Sim

RA10 Sim

RA11 Sim

RA12 Sim

RA13 Sim

RA14 Sim

RA15 Sim

RA16 Sim

RA17 Sim

RA18 Sim

RA19 Sim

RA20 Sim

Questão 15: Em caso de resposta positiva à questão anterior, quais? 
RA1 Grupo do Google

RA2 Grupo de emails do correio eletrônico convencional

RA3 -

RA4 Grupo de emails do correio eletrônico convencional

RA5 Grupo do Google

RA6 Grupo de emails do correio eletrônico convencional

RA7 Grupo do Google

RA8 Grupo de emails do correio eletrônico convencional

RA9 Grupo do Google

RA10 Grupo de emails do correio eletrônico convencional, Grupo do Google

RA11 Grupo de emails do correio eletrônico convencional

RA12 Ambiente educacional do tipo plataforma Moodle

RA13 Grupo de emails do correio eletrônico convencional, Ambiente educacional do tipo plataforma Moodle

RA14 Ambiente educacional do tipo plataforma Moodle

RA15 Ambiente educacional do tipo plataforma Moodle

RA16 Grupo de emails do correio eletrônico convencional

RA17 Grupo de emails do correio eletrônico convencional, Ambiente educacional do tipo plataforma Moodle

RA18 Grupo de emails do correio eletrônico convencional

RA19 Grupo de emails do correio eletrônico convencional

RA20 Grupo de emails do correio eletrônico convencional

Questão 16: Você enfrenta algum tipo de problema por conta da utilização desses ambientes virtuais?

RA1 Não

RA2 Não

RA3 -

RA4 Não

RA5 Não

RA6 Não

RA7 Não

RA8 Não 
RA9 Não

RA10 Não

RA11 Não

RA12 Não

RA13 Não

RA14 Não

RA15 Não

RA16 Não

RA17 Não

RA18 Não

RA19 Não

RA20 Não

Questão 17: Em caso positivo, qual/quais?

RA1 -

RA2 -

RA3 -

RA4 -

RA5 -

RA6 -

RA7 -

RA8 -

RA9 -

RA10 -

RA11 -

RA12 -

RA13 -

RA14 -

RA15 -

RA16 -

RA17 -

RA18 - 
RA19 -

RA20 -

Questão 18: Você avalia positiva ou negativamente a utilização do ambiente virtual?

RA1 Positivamente

RA2 Positivamente

RA3 -

RA4 Positivamente

RA5 Positivamente

RA6 Positivamente

RA7 Positivamente

RA8 Positivamente

RA9 Positivamente

RA10 Positivamente

RA11 Positivamente

RA12 Positivamente

RA13 Positivamente

RA14 Positivamente

RA15 Positivamente

RA16 Positivamente

RA17 Positivamente

RA18 Positivamente

RA19 Positivamente

RA20 Positivamente

Questão 19: Você acredita que todos participam igualmente das atividades desenvolvidas no ambiente virtual?

RA1 Sim

RA2 Sim

RA3 -

RA4 Sim

RA5 Sim 
RA6 Não

RA7 Sim

RA8 Não

RA9 Não

RA10 Não

RA11 Sim

RA12 Não

RA13 Não

RA14 Não

RA15 Sim

RA16 Não

RA17 Sim

RA18 Sim

RA19 Não

RA20 Não

Questão 20: Você e/ou seus colegas tiveram dificuldades no acesso ao ambiente virtual? Comente.

RA1 Não.

RA2 Não, foi bem fácil a comunicação com a professora e entrega de trabalhos.

RA3 -

RA4 Não foram enfrentadas dificuldades.

RA5 Não. No geral, os meus colegas tem acesso ao ambiente virtual, sem dificuldades.

RA6 Não, há computadores com acesso à internet na faculdade.

RA7 a turma era nova, todos estavam acostumados ao ambiente virtual.

RA8 Não

RA9 Não

RA10 -

RA11 Não tive dificuldades. Não tomei conhecimento, também, de dificuldades alheias.

RA12 "Tive dificuldades a principio com o moodle, para entender seu funcionamento e acredito que esta seja uma dificuldade geral. Porém, pessoalmente, depois que compreendi o funcionamento da plataforma não tive mais dificuldades."

RA13 Não tive problemas com a plataforma. 
RA14 Não.

RA15 -

RA16 Não, mas prefiro a aula expositiva, com considerações frente a frente.

RA17 NÃO. ACREDITO QUE O AMBIENTE VIRTUAL FACILITA O APRENDIZADO. POREM MUITAS VEZES ISSO É CONFUNDIDO PELOS ALUNOS COMO MAIS TRABALHO.

RA18 -

RA19 -

RA20 DIANTE DO MEU POSICIONAMENTO ACREDITO QUE NÃO, ATÉ MESMO PELO FATO DO AMBIENTE VIRTUAL PROPORCIONAR DE CERTA FORMA MAIS FACILIDADE DE COMUNICAÇÃO ENTRE AS PESSOAS.

Questão 21: Quanto aos resultados em termos de aprendizagem, você acredita que o curso e as atividades em ambiente virtual contribuíram para a construção de conhecimentos novos para você?

RA1 Sim

RA2 Sim

RA3 -

RA4 Sim

RA5 Não

RA6 Não

RA7 Sim

RA8 Sim

RA9 Sim

RA10 Sim

RA11 Sim

RA12 Sim

RA13 Sim

RA14 Sim

RA15 Sim

RA16 Sim

RA17 Sim

RA18 Não

RA19 Não 
RA20 Sim

\section{Questão 22: Qual é a sua opinião sobre o ambiente virtual como canal de apoio ao} ensino? Comente.

RA1 Considero muito bom por facilitar o compartilhamento de materiais didáticos.

RA2 Atualmente é o meio mais fácil e eficiente de auxílio ao ensino pois seu uso é disseminado entre praticamente todos os alunos do meu curso.

RA3 -

RA4 O ambiente virtual auxilia na comunicação rápida e em grande escala.

RA5 Além de ser muito importante a inserção das fases do aprendizado nos meios virtuais, esse ato facilita muitos processos, como o transporte de informações sobre o curso de maneira rápida e eficiente.

RA6 Apoio o uso do ambiente virtual como auxílio ou feedback das aulas, não como parte do ensino em si.

RA7 Totalmente favorável.

RA8 Beneficio para a aquisição de material e de informações a serem transmitidas!

RA9 O ambiente virtual é bom, pois deixa a aula mais interessante e facilita bastante a visualização dos gráficos.

RA10 Apoio essa utilização, pois estreita o caminho professor-aluno. E também, no meu caso, as aulas eram só uma vez por semana, então se alguma dúvida surgisse não precisávamos esperar 1 semana até a próxima aula e etc.

RA11 Considero o ambiente virtual um importante aliado do ensino, sobretudo em nossos tempos; porém, não deve ser exclusivo. As aulas presenciais são, ainda, essenciais.

RA12 Acredito que seja necessário que o ensino acompanhe o desenvolvimento da tecnologia. Porém, não acredito em um ensino que seja feito somente a distância. Penso que os dois devem caminhar em conjunto.

RA13 Acho que é uma maneira dos alunos interagirem e, por vezes, dúvidas de alguns pode ser de todo mundo.

RA14 Em tempos de internet, é um modo inteligente de aprimorar o estudo e conversar com os educadores.

RA15 O ambiente virtual foi bastante importante para ter acesso a textos, contato com a monitora do curso para esclarecimento de dúvidas bem como orientação de trabalhos, complementando o que foi desenvolvido em sala de aula.

RA16 Gosto do meio virtual como 'auxílio' no aprendizado. Mas não acredito no ambiente virtual substituindo a sala de aula.

RA17 ACREDITO QUE SEJA POSITIVO. POREM ALGUNS PROFESSORES EXAGERAM EM SEU USO. COMO VOCE MESMO DISSE "APOIO". ISTO NAO SIGNIFICA "OVER WORK".

RA18 Positiva. No mundo atual é quase impossível não usar o ambiente virtual. 
RA19 O sucesso de um ambiente virtual com fins educacionais depende da qualidade das interações que ali se desenvolverão tanto entre professor e alunos quanto entre alunos. Daí a necessidade, a meu ver, de se disponibilizar (e investir esforços em) fóruns de discussão nesses ambientes. E se não houver um (ou mais) bom (ns) mediadore(s) (ou seja, pessoas que incentivem as interações, comentando/questionando o que foi postado) desses fóruns, não faz muito sentido adotar um ambiente virtual. Estamos acostumados a ver mais esses ambientes sendo utilizados como repositórios de conteúdo do que como espaço democrático de discussões. Sem interação, contudo, não há aprendizagem.

RA20 É UM CANAL QUE PRODUZ RETORNO, CLARO QUE SEMPRE DEVEMOS ESTAR ATENTOS AOS SITES CONSULTADOS PARA SABER SE AS INFORMAÇÕES DITAS NELE SÃO VERÍDICAS OU MERAS ILUSÕES "MENTIRAS, POIS COM O AVANÇO DA TECNOLOGIA TUDO FICA MAIS FÁCIL, COM APENAS UM CLICK SE CONSEGUE TER ACESSO A INÚMERAS INFORMAÇÕES IMPORTANTES PARA A APRENDIZAGEM DO SER HUMANO. SIM, O AMBIENTE VIRTUAL É UM CANAL DE APOIO AO ENSINO. VALE RESSALTAR QUE, ELE SERVE PARA APOIAR E, NUNCA PARA SUBSTITUIR A FUNÇÃO QUE EXERCE UM PROFESSOR(A). 